\title{
Tectonic setting of faulted Tertiary strata associated with the Catalina core complex in southern Arizona
}

William R. Dickinson
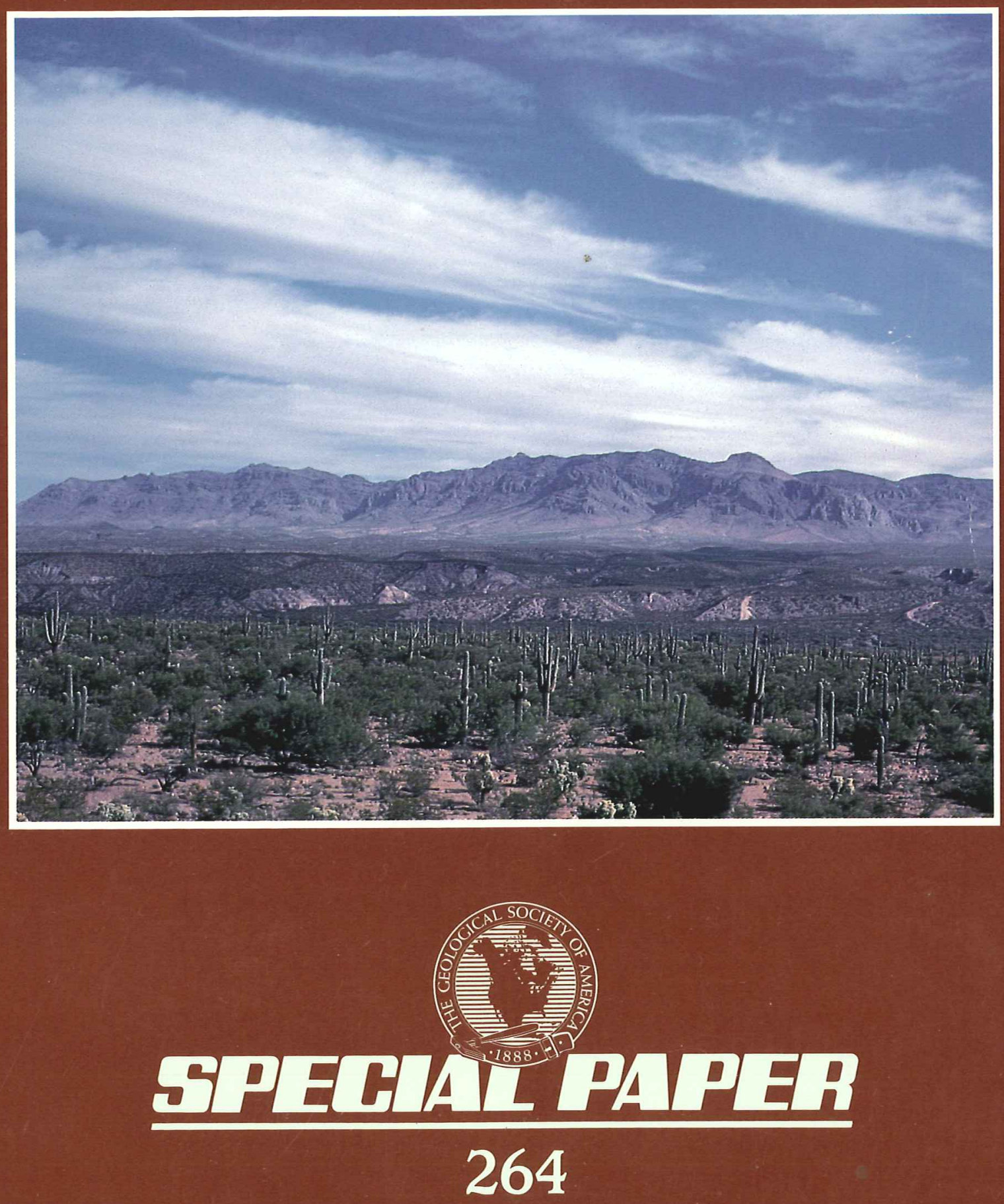


\section{Tectonic setting of faulted Tertiary strata associated with the Catalina core complex in southern Arizona}

William R. Dickinson

Department of Geosciences

University of Arizona

Tucson, Arizona 85721

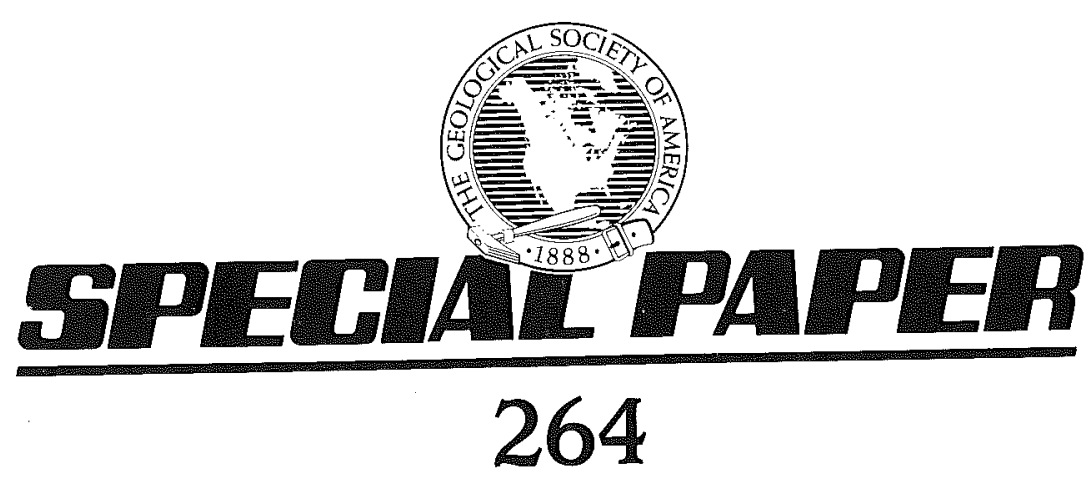


(C) 1991 The Geological Society of America, Inc.

All rights reserved.

All materials subject to this copyright and included in this volume may be photocopied for the noncommercial purpose of scientific or educational advancement.

Published by The Geological Society of America, Inc.

3300 Penrose Place, P.O. Box 9140, Boulder, Colorado 80301

Printed in U.S.A.

GSA Books Science Editor Richard A. Hoppin

Library of Congress Cataloging-in-Publication Data

Dickinson, William R.

Tectonic setting of faulted tertiary strata associated with the Catalina core complex in southern Arizona / William R. Dickinson.

p. $\quad$ cm.-(Special paper ; 264)

Includes bibliographical references.

ISBN 0-8137-2264-0

1. Geology, Stratigraphic-Tertiary. 2. Geology, Structural-Arizona. 3. Geology-Arizona. I. Title. II. Series: Special papers (Geological Society of America) ; 264.

QE736.D55 1991

$551.7^{\prime} 8^{\prime} 09791-\mathrm{dc} 20$

91-17084

CIP

Cover photo: View northeast across floor of San Pedro trough past incised drainage of San Pedro River in middle ground toward range front of Galiuro Mountains on skyline. 


\section{Contents}

Acknowledgments $\ldots \ldots \ldots \ldots \ldots \ldots \ldots \ldots \ldots \ldots \ldots \ldots \ldots \ldots \ldots \ldots \ldots \ldots \ldots \ldots$ vii

Abstract $\ldots \ldots \ldots \ldots \ldots \ldots \ldots \ldots \ldots \ldots \ldots \ldots \ldots \ldots \ldots \ldots \ldots \ldots, 1$

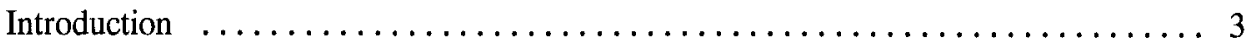

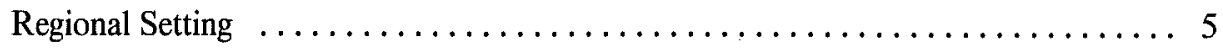

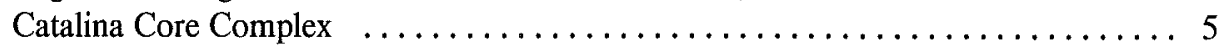

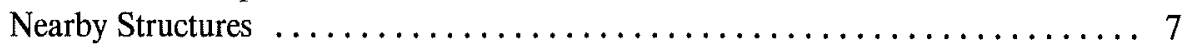

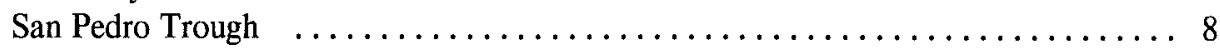

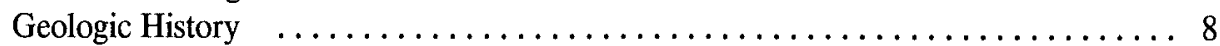

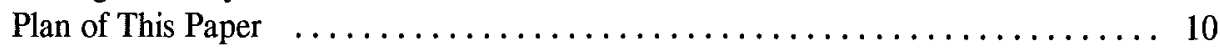

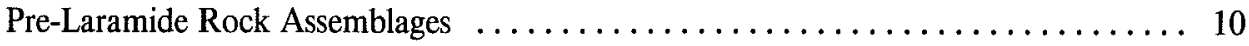

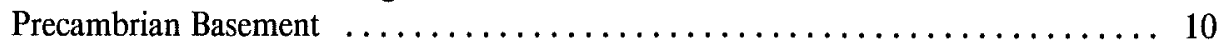

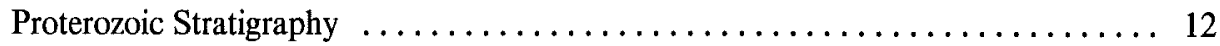

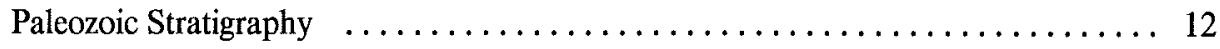

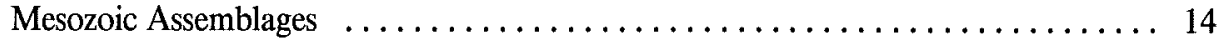

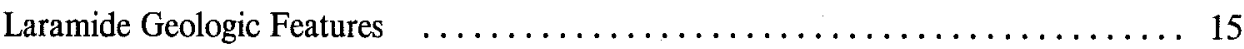

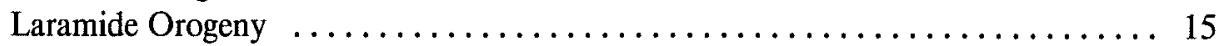

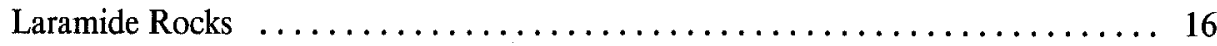

Metaluminous Intrusions and Volcanic Fields $\ldots \ldots \ldots \ldots \ldots \ldots \ldots \ldots, 18$

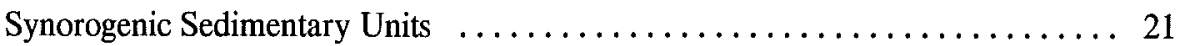

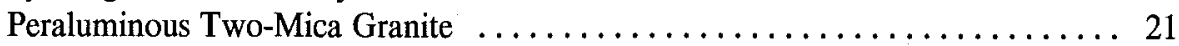

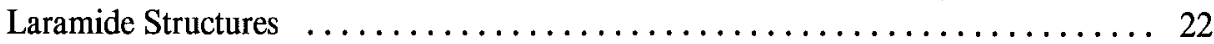

Ductile Structures Inside the Core Complex $\ldots \ldots \ldots \ldots \ldots \ldots \ldots \ldots . \ldots 22$

Brittle Structures Outside the Core Complex $\ldots \ldots \ldots \ldots \ldots \ldots \ldots \ldots 23$

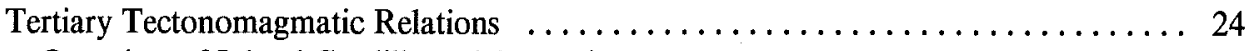

Overview of Inland Cordilleran Magmatism $\ldots \ldots \ldots \ldots \ldots \ldots \ldots \ldots \ldots . \ldots \ldots$

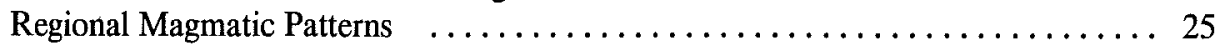

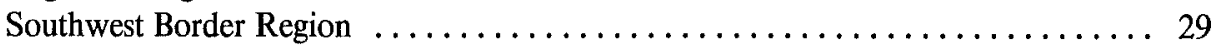

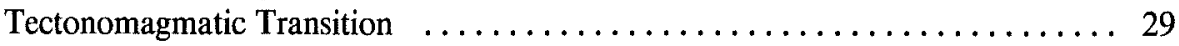

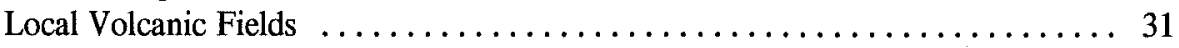

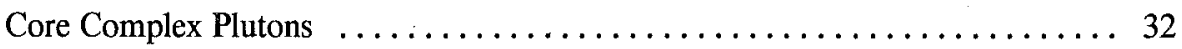




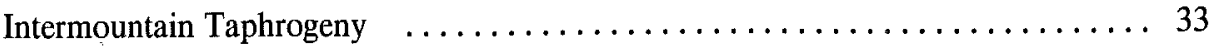

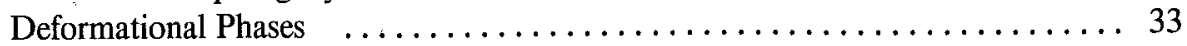

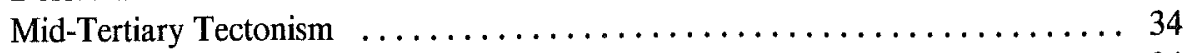

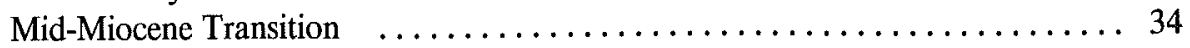

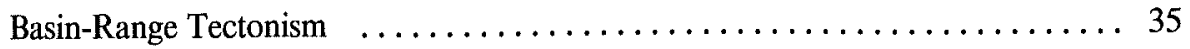

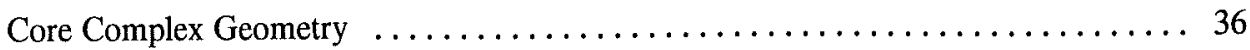

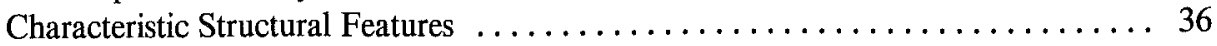

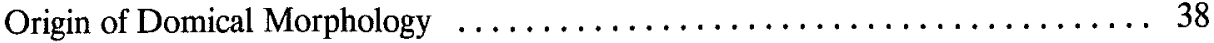

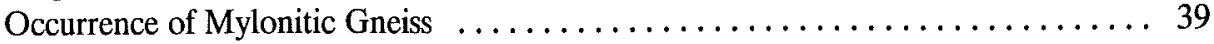

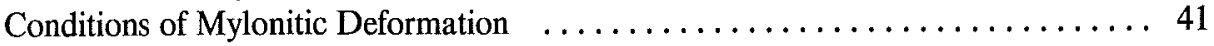

Configuration of Detachment System $\ldots \ldots \ldots \ldots \ldots \ldots \ldots \ldots \ldots \ldots \ldots \ldots$. 41

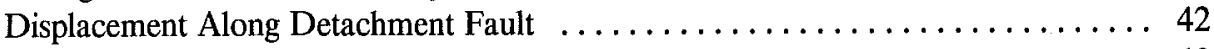

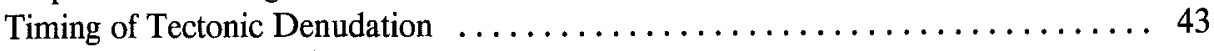

Alternate Structural Models $\ldots \ldots \ldots \ldots \ldots \ldots \ldots \ldots \ldots \ldots \ldots \ldots \ldots \ldots \ldots \ldots \ldots$

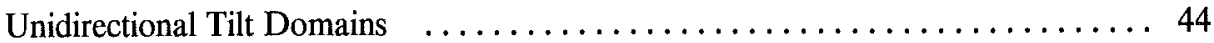

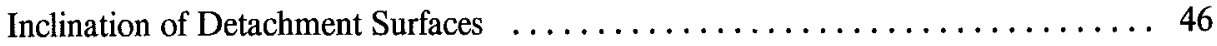

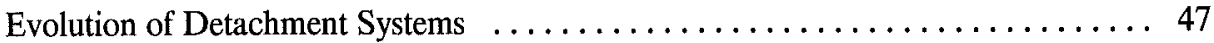

Kinematics of Detachment Faults $\ldots \ldots \ldots \ldots \ldots \ldots \ldots \ldots \ldots \ldots \ldots \ldots \ldots \ldots$

Contrasting Rotational Mechanisms $\ldots \ldots \ldots \ldots \ldots \ldots \ldots \ldots \ldots \ldots \ldots \ldots \ldots$

Tertiary Sedimentary Assemblages $\ldots \ldots \ldots \ldots \ldots \ldots \ldots \ldots \ldots \ldots \ldots \ldots \ldots \ldots \ldots$

Overall Facies Framework .......................... 49

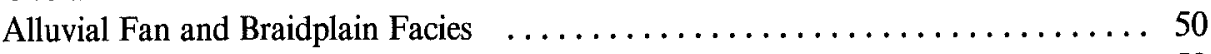

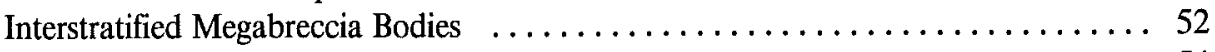

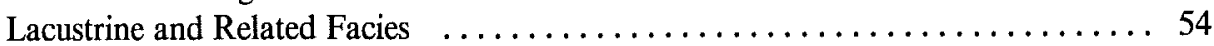

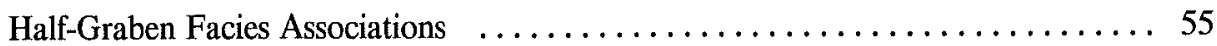

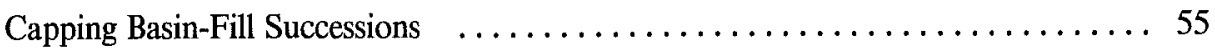

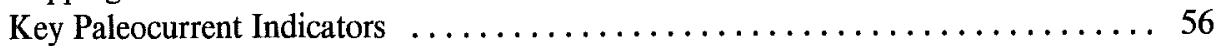

Tertiary Stratigraphic Framework $\ldots \ldots \ldots \ldots \ldots \ldots \ldots \ldots \ldots \ldots \ldots \ldots \ldots$

Mid-Tertiary Units $\ldots \ldots \ldots \ldots \ldots \ldots \ldots \ldots \ldots \ldots \ldots \ldots \ldots \ldots \ldots \ldots$

Mineta Formation $\ldots \ldots \ldots \ldots \ldots \ldots \ldots \ldots \ldots \ldots \ldots \ldots \ldots \ldots \ldots \ldots$

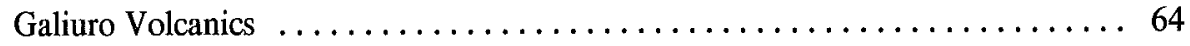

Cloudburst Formation $\ldots \ldots \ldots \ldots \ldots \ldots \ldots \ldots \ldots \ldots \ldots \ldots \ldots \ldots \ldots$

Cloudburst/San Manuel Contact $\ldots \ldots \ldots \ldots \ldots \ldots \ldots \ldots \ldots \ldots \ldots \ldots \ldots$

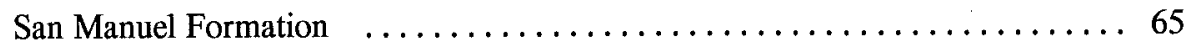

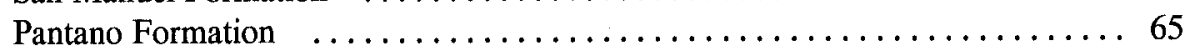

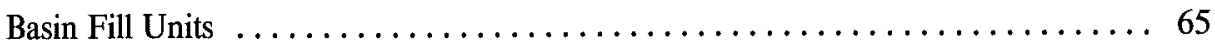

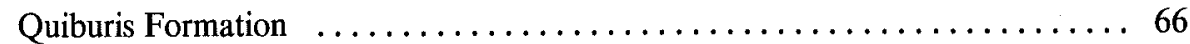

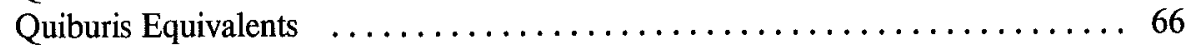

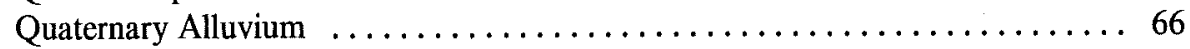

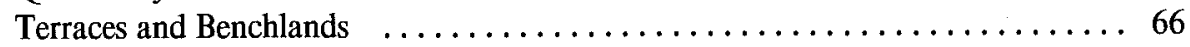

Subarea Structure and Stratigraphy $\ldots \ldots \ldots \ldots \ldots \ldots \ldots \ldots \ldots \ldots \ldots \ldots \ldots \ldots$

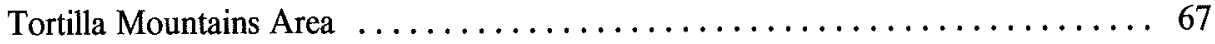

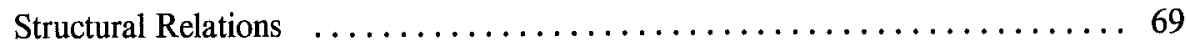

Hackberry Wash Facies of Cloudburst Formation $\ldots \ldots \ldots \ldots \ldots \ldots \ldots \ldots$

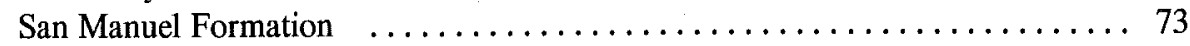

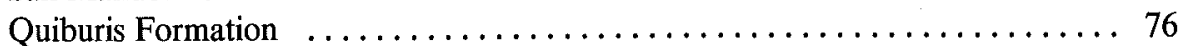

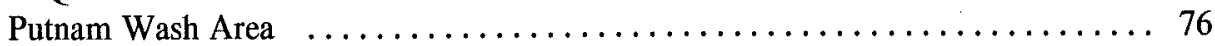

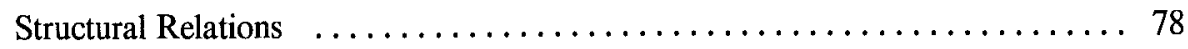

Stratigraphic Relations $\ldots \ldots \ldots \ldots \ldots \ldots \ldots \ldots \ldots \ldots \ldots \ldots \ldots$ 


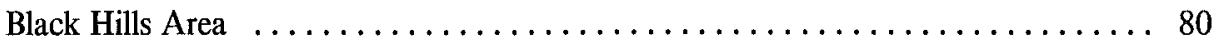

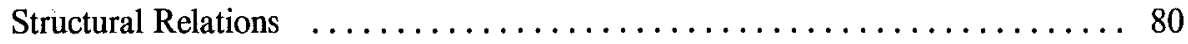

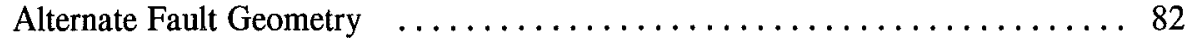

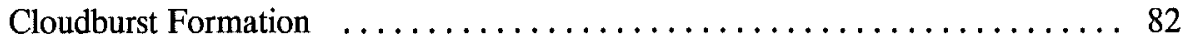

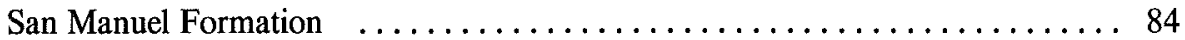

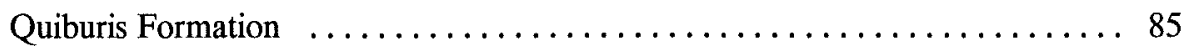

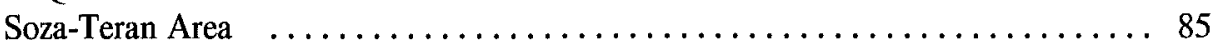

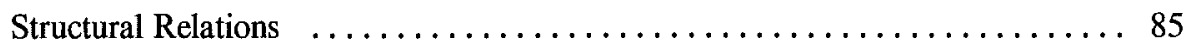

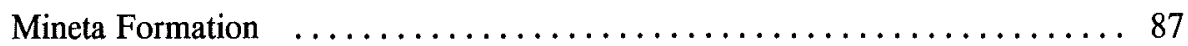

San Manuel Formation $\ldots \ldots \ldots \ldots \ldots \ldots \ldots \ldots \ldots \ldots \ldots \ldots \ldots$

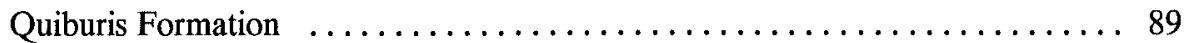

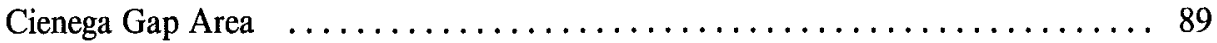

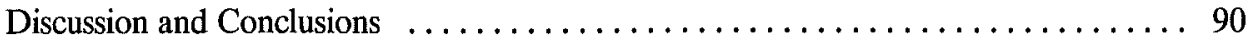

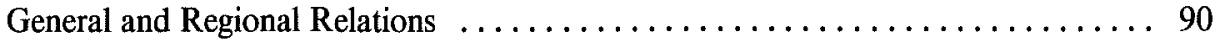

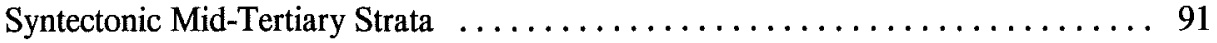

Detachment Timing and Displacement $\ldots \ldots \ldots \ldots \ldots \ldots \ldots \ldots \ldots \ldots . \ldots 1$

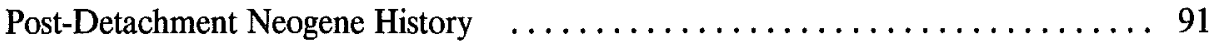

Kinematic and Geometric Uncertainties $\ldots \ldots \ldots \ldots \ldots \ldots \ldots \ldots \ldots \ldots . \ldots \ldots$

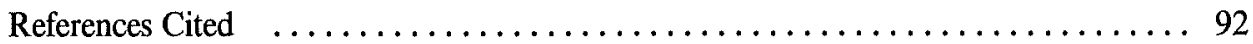




\section{Acknowledgments}

This project was initiated by the following participants in the 1980 Chimichanga Seminar at the University of Arizona: J. A. Grover, L. E. Harding, K. F. Inman, K. Jamison, R. A. LeVeque, S. H. Lingrey, W. C. McClelland, J. Quade, S. M. Richard, D. M. Taylor, and W. L. Weibel.

I am also indebted to scores of previous workers who prepared detailed geologic maps of various parts of the study area prior to my work. Special attention is called to the efforts of several USGS geologists, and their co-workers, whose multiple quadrangle maps formed an indispensable background for the present investigation: N. G. Banks in the Santa Catalina and Tortolita Mountains, S. C. Creasey in the Santa Catalina and Galiuro Mountains, H. D. Drewes in the Rincon Mountains, and most notably M. H. Krieger in 12 key contiguous quadrangles occupying parts of the Tortilla, Dripping Spring, and Galiuro Mountains.

My understanding of the Catalina core complex has been nurtured for a decade by discussions with P. J. Coney, P. E. Damon, G. H. Davis, S. B. Keith, and S. J. Reynolds. Further insight has come from recent discussions with L. A. Anovitz, C. G. Chase, E. R. Force, G. E. Gehrels, R. A. Johnson, R. R. Richardson, and T. C. Wallace. Discussions with H. W. Peirce and R. B. Scarborough about Tertiary basins in Arizona were also especially helpful. Oral presentations by R. L. Armstrong, P. J. Coney, P. B. Gans, and J. Jackson at the 1987 Elko Penrose Conference on Cordilleran metamorphic core complexes helped me formulate critical ideas. Throughout the study, M. Shafiqullah provided unselfish geochronological advice and support.

Information derived from theses and dissertations of the following graduate students at the University of Arizona form an integral part of my own knowledge about the study area: R. S. Balcer, A. Burchell, A. Bykerk-Kauffman, T. C. Goodlin, J. A. Grover, J. B. Hansen, S. U. Janecke, S. H. Lingrey, R. A. Mark, S. J. Naruk, M. D. Olivares, R. Risley, J. D. Shenk, C. H. Smith, P. N. Swift, J. L. Walsh, W. L. Weibel, and J. C. Yarnold. Moreover, the earlier graduate research of E. A. Schmidt was seminal for my own interpretations.

Conclusions about geologic relationships were improved by discussions during special field trips with C. J. Ando, M. N. Bass, R. Brett, R. N. Brothers, R. D. Conrad, D. S. Cowan, W. K. Gealey, S. A. Graham, D. D. Hastings, R. Higgins, R. V. Ingersoll, T. E. Jordan, C. F. Kluth, C. A. Landis, E. C. Leitch, J. D. Lowell, J. C. Moore, E. M. Moores, C. McA. Powell, J. G. Ramsey, F. Royse, D. R. Seely, C. A. Simpson, S. B. Smithson, W. S. Snyder, K. E. Telleen, G. A. Thompson, and B. P. Wernicke.

Partial financial support was provided by National Science Foundation Grant EAR8018231 and the Chaplin Fund of the Laboratory of Geotectonics at the University of Arizona. My wife, J. J. Dickinson, was a constant companion during the field work, and 
discussions about extensional tectonics with our son, J. E. Spencer, were of unique benefit to me. Finally, the project would have been impossible without the inspiration provided by W. D. Darton.

I thank J.M.G. Miller and G. W. Viele for thoughtful reviews that notably improved the manuscript. All figures were drafted by Rick Brokaw. 


\title{
Tectonic setting of faulted Tertiary strata associated with the Catalina core complex in southern Arizona
}

\begin{abstract}
Stratigraphic and structural relations of syntectonic sedimentary sequences associated with Cordilleran metamorphic core complexes provide valuable information about the style and timing of extensional deformation related to tectonic denudation. Adjacent to the Catalina core complex, the San Pedro trough and other nearby depocenters contain multiple tilted half-grabens of conglomeratic mid-Tertiary strata partly buried beneath Neogene basin fill. Major episodes of local geologic history included mid-Proterozoic construction of continental crust, subsequent but intermittent platform sedimentation extending through Paleozoic time, mid-Mesozoic initiation of arc magmatism that persisted at intervals through mid-Tertiary time, complex Laramide orogenic deformation of latest Cretaceous to early Tertiary age, and Cenozoic extensional deformation involving both mid-Tertiary and basin-range phases of development.

Precambrian basement includes lower Proterozoic Pinal Schist intruded by voluminous lower to middle Proterozoic granitic plutons. Pre-Laramide stratigraphic cover includes middle Proterozoic sedimentary strata and intercalated diabase sills, Paleozoic carbonate and clastic units, and Mesozoic volcaniclastic and clastic successions. Laramide assemblages include metaluminous plutons and andesitic to rhyolitic volcanic fields, synorogenic nonmarine sedimentary sequences, and large bodies of peraluminous two-mica granite. Laramide structural features include both premetamorphic and ductile synmetamorphic thrusts within the Catalina core complex, brittle thrusts of uncertain vergence and overall configuration outside the Catalina core complex, and folds of varied geometry related in part to local thrusts exposed nearby. Paleogene erosion had stripped Laramide volcanic cover from wide areas by mid-Tertiary time.

Migratory Tertiary arc magmatism within the intermountain region gave rise to diachronous polymodal igneous suites, represented within and near the Catalina core complex by extensive volcanic fields and local granitic plutons of late Oligocene age. Across the whole Southwest Border region, analogous mid-Tertiary igneous activity was succeeded, following an intra-Miocene tectonomagmatic transition, by basaltic to bimodal suites erupted during subsequent block faulting.

Tertiary intermountain taphrogeny included a mid-Tertiary phase marked by listric or rotational normal faulting associated with tectonic denudation of core complexes along detachment systems, and a later basin-range phase of widespread block faulting. Mid-Tertiary extension was apparently promoted by reduction of interplate shear, kinematic rollback of a subducted slab, lateral spreading of overthickened crust, advective softening of arc lithosphere, and possibly by counterflow of asthenosphere. Basinrange extension was evidently initiated by shear coupling of Pacific and American lithosphere.

The Catalina core complex displays characteristic geologic features: mylonitic fabric overprinted near a detachment fault by brecciation and chloritic alteration, a brittle
\end{abstract}


detachment surface abruptly separating rock masses derived from different crustal levels, cover strata broken into multiple tilted fault blocks forming a shingled imbricate array, and surrounding syntectonic sedimentary sequences containing intercalated megabreccia horizons. The domical uplift that controls the exposed extent of the Catalina core complex apparently reflects isostatic upwarp of the midcrust in response to tectonic denudation, coupled with rollover arching above listric faults cutting beneath the core complex and with later uplift of crustal masses along steep block faults.

A belt of mylonitic gneiss $10 \mathrm{~km}$ wide and $100 \mathrm{~km}$ long lies along the southwest flank of the Catalina core complex adjacent to the downdip segment of the detachment fault. Updip segments of the detachment system, across which cumulative displacement is estimated as 20 to $30 \mathrm{~km}$, curve over and around the exposed core complex to merge with an inferred headwall rupture along the trend of the San Pedro trough. The detachment system probably involved a gently dipping aseismic slip surface beneath surficial tilted fault blocks; alternatively, faults now dipping gently may have originated as steep structures that rotated to shallow dips as slip proceeded. Field relations around the Catalina core complex are seemingly more compatible with the former interpretation, but insights gained from the alternate interpretation are useful for structural analysis of rotated tilt-blocks above the master detachment surface. Kinematic considerations imply that displacements within the local detachment system were diachronous during its evolution, but mylonitic deformation and detachment faulting both occurred during late Oligocene and early Miocene time.

Tilted homoclines of syntectonic mid-Tertiary strata and less deformed beds of younger basin fill are both composed dominantly of alluvial fan and braidplain facies that grade laterally to finer-grained fluvial and lacustrine facies. Subordinate deposits include landslide megabreccia, algal limestone, lacustrine diatomite, and playa gypsum. The most voluminous strata are crudely bedded conglomerate and conglomeratic sandstone deposited by braided depositional systems. Clast imbrication is the most widespread and reliable paleocurrent indicator. Mid-Tertiary aggradation in half-graben basins gave rise to sedimentary onlap and overstep of evolving tilt-blocks, intricate local facies relations, and marked stratigraphic contrasts between sequences deposited within partly isolated subbasins. Stratigraphic successions that are concordant within basin depocenters are commonly broken by unconformities and intervals of nondeposition on basin flanks and across crests of bounding tilt-blocks.

Mid-Tertiary strata exposed as tilted homoclines along the flanks of the San Pedro trough and across broad uplands north of the Catalina core complex are assigned to the following formations, each of which includes informal local members and facies: (a) Mineta Formation, mid-Oligocene redbeds including both conglomeratic fluvial and finer-grained lacustrine deposits; (b) Galiuro Volcanics, including lavas and domes, air-fall and ash-flow tuffs, and intercalated volcaniclastic strata of late Oligocene to earliest Miocene age; (c) Cloudburst Formation, also of late Oligocene and earliest Miocene age but including a sedimentary upper member of conglomeratic strata as well as a volcanic lower member correlative with part of the Galiuro Volcanics; and (d) San Manuel Formation, composed of lower Miocene alluvial fan and braidplain deposits that display contrasting clast assemblages in different areas of exposure. Generally correlative Oligocene-Miocene strata exposed south of the Catalina core complex are assigned to the Pantano Formation, which contains similar lithologic components. Less-deformed Neogene strata of post-mid-Miocene basin fill are assigned to the Quiburis Formation along the San Pedro trough, but stratigraphic equivalents elsewhere lack adequate nomenclature. High benchlands mantled by paleosols mark the highest levels of Neogene aggradation. Successive stages of subsequent erosional dissection are recorded by multiple terrace levels incised into basin fill.

Key exposures of syntectonic mid-Tertiary sedimentary sequences in several local subareas reveal typical structural and stratigraphic relationships. Multiple fault blocks expose pre-Tertiary bedrock overlain by tilted mid-Tertiary strata confined to interven- 
ing half-grabens. Bounding syndepositional faults dip southwest and associated homoclines dip northeast. Fanning dips and buttress unconformities reflect progressive tilt and burial of eroding fault blocks. Dips of block-bounding faults are inversely proportional to the ages of the faults. Steeper dips for younger faults suggest either progressive erosion of successive listric faults or progressive rotation of successive planar faults. Uniformly moderate to steep dihedral angles between fault surfaces and offset homoclinal bedding imply that the faults dipped more steeply near the surface when syntectonic mid-Tertiary strata were subhorizontal. Although the inference of listric faulting best links apparent strands of the Catalina detachment system, the alternate interpretation of rotational normal faulting is compatible with local structural relationships including tilt of porphyry copper orebodies.

Within the San Pedro trough, multiple homoclines of mid-Tertiary strata are exposed locally in tilt-blocks exhumed by Neogene erosion from beneath nearly flat-lying basin fill of the Quiburis Formation. Faults bounding the mid-Tertiary exposures include backtilted strands of the Catalina detachment system, somewhat younger listric or rotational normal faults, and steeper basin-range normal faults that display offsets both synthetic and antithetic to the flanks of the San Petro trough.

In Cienega Gap, flanking the Tucson Basin, multiple tilt-blocks of the Pantano Formation form part of the upper plate of the Catalina detachment system. Initial construction of alluvial fans by generally westward paleoflow was followed by ponding of lacustrine environments along the foot of secondary breakaway scarps that also generated massive megabreccia deposits.

In summary, syntectonic Oligocene to Miocene sedimentation succeeded a prominent pulse of polymodal mid-Tertiary volcanism and was coeval with mylonitic deformation and detachment faulting along the flank of the Catalina core complex. The headwall rupture for the detachment system migrated westward from an initial position along the range front of the Galiuro Mountains. After mid-Miocene time, accumulation and subsequent dissection of essentially undeformed basin fill was accompanied by basin-range block faulting. The most challenging structural issue is whether fault strands of the Catalina detachment system are interconnected or are disconnected rotational segments.

\section{INTRODUCTION}

This Special Paper presents an overview of the tectonic setting, stratigraphic framework, and structural relations of syntectonic mid-Tertiary sedimentary sequences exposed within an area of varied topography surrounding the Catalina core complex and the cogenetic San Pedro trough in southern Arizona. The general geologic map of Figure 1 (in pocket inside back cover) $\left(\sim 10^{4} \mathrm{~km}^{2}\right)$ is based on compilation and reinterpretation of previous mapping supplemented by personal reconnaissance during the past decade (Dickinson, 1987, 1988). The usage of Keith and others (1980) is adopted for the designation of bedrock units within the Catalina core complex and the stratigraphic nomenclature of Dickinson and Shafiqullah (1989) is followed for Cenozoic strata within the San Pedro trough and nearby depocenters (Fig. 2). No attempt is made here to recapitulate all that has been learned about each local set of mid-Tertiary outcrops, but the general geologic context of each main group of exposures is reviewed as a guide to more specific future investigations.

The impetus for study of the mid-Tertiary strata was a desire to constrain tectonic models for the evolution of Cordilleran metamorphic core complexes (Crittenden and others, 1980).
Previous investigations, with emphasis on structural and metamorphic features within deformed bedrock, need to be augmented by analysis of the distribution and facies geometry of syntectonic sedimentary sequences. Deposition of stratal successions during extensional faulting was coeval with the development of core-complex structures at depth (Miller and John, 1988). The sedimentary approach is important because interpretations of many kinds of basic sedimentary relationships are inherently less ambiguous than interpretations of metamorphic and deformational fabrics, for which actualistic controls are typically less stringent. Because sedimentary studies can define the evolving nature of structures controlling surface topography, they may produce unique insights for understanding the geometry of extensional deformation related to core complexes.

Taphrogeny, or extensional tectonism in its varied modes (Wernicke and Burchfiel, 1982), has influenced the evolution of continental crust through time as surely as has the contractional strain of orogeny. The dozens of Cordilleran metamorphic core complexes distributed along some $2,500 \mathrm{~km}$ of the intermountain belt from southern Canada to northern Mexico (Coney, 1980b) are worthy of careful study because they constitute perhaps the most dramatic record of intraplate extension exposed to view 


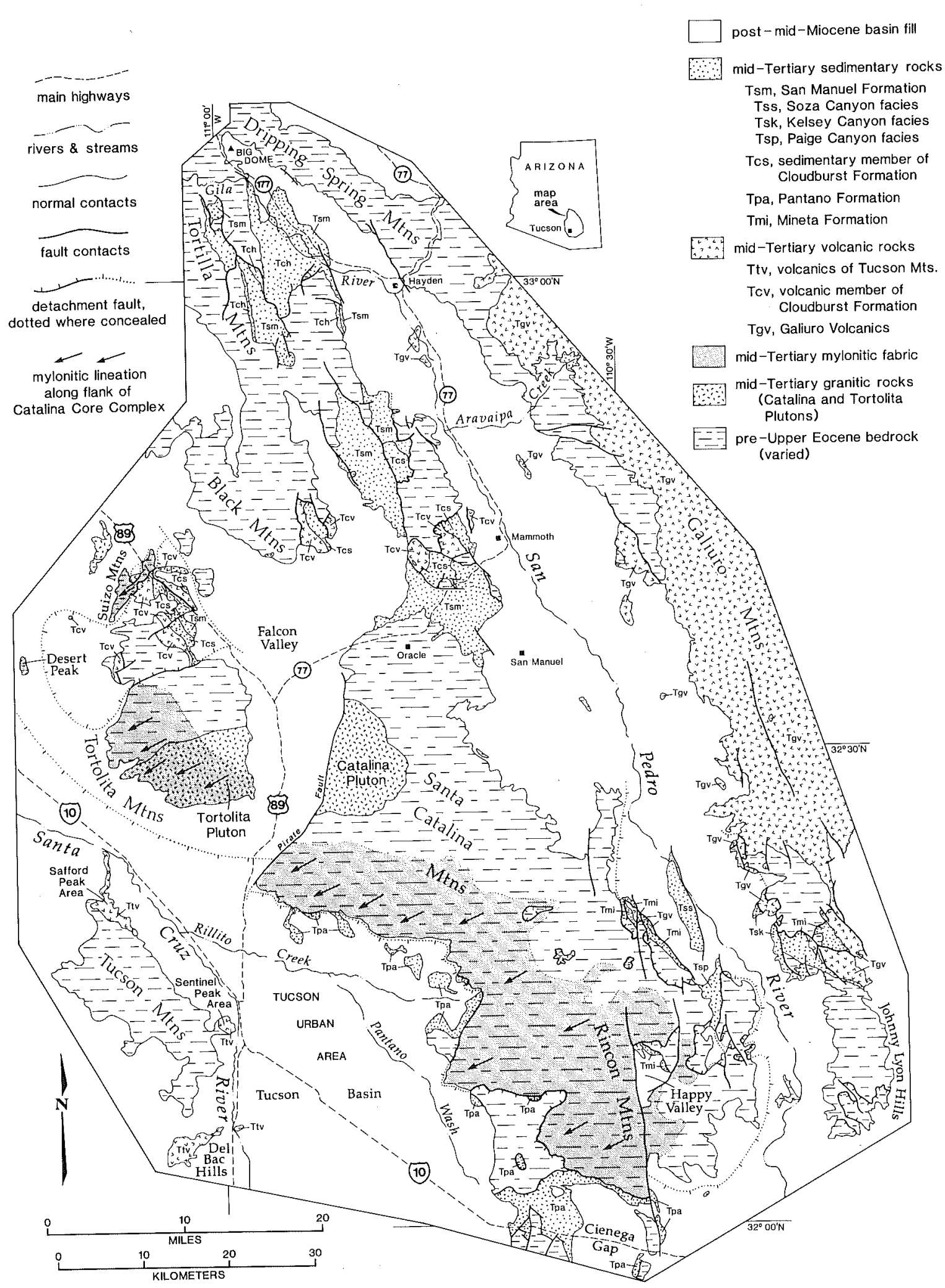

Figure 2. Geologic sketch map of Catalina core complex (mylonitic foliation and lineation along southwest flank) and San Pedro trough (traversed by San Pedro River and by Gila River below their confluence) showing areal distribution of tilted homoclines of mid-Tertiary volcanic and sedimentary successions in relation to exposures of older bedrock and younger basin fill; modified after Dickinson and Shafiqullah (1989). 
anywhere on land. As close analogies can be drawn between the geometry of basement structures beneath rifted continental margins (LePichon and Sibuet, 1981) and the structural configuration of typical core complexes (Lister and others, 1986), geologic relationships similar to those observed in exposed core complexes may exist in the substratum beneath many sedimentary basins (Verosub and Moores, 1981).

\section{Regional setting}

Cordilleran metamorphic core complexes were defined by Coney (1980a) as "a group of generally domal or archlike, isolated uplifts of anomalously deformed [i.e., mylonitic] metamorphic and plutonic rocks overlain by a tectonically detached and distended unmetamorphosed cover." Most display internal evidence of multiepisodic and polygenetic evolution involving Mesozoic contractional structures and fabrics overprinted by the effects of Cenozoic extensional events (DeWitt, 1980; Armstrong, 1982). Preserved mineral assemblages record polymetamorphism associated with successive stages of their structural development (Hansen and Goodge, 1988; Miller and Gans, 1989; John and Mukasa, 1990). G. H. Davis and Coney (1979) first stressed the view that the characteristic geometry of typical core complexes is fundamentally the record of the extensional part of their history. The dominance of this extensional overprint was long doubted by many, particularly for Canadian examples, but recent work in Canada has confirmed the critical role of extensional tectonism in the evolution of core complexes there as well (Templeman-Kluit and Parkinson, 1986; Brown and Journeay, 1987; Carr and others, 1987; Parrish and others, 1988; Friedman and Armstrong, 1988).

The characteristic structural geometry of metamorphic core complexes is generally interpreted now as the product of extensional displacements along brittle-ductile shear zones (Ramsey, 1980) that penetrated to midcrustal levels (G. H. Davis, 1983, 1987; Reynolds, 1985; Wernicke, 1985; G. A. Davis and others, 1986; Spencer and Reynolds, 1986, 1989a, c; G. A. Davis and Lister, 1988; Glazner and others, 1988; Reynolds and others, 1988; Snoke and Miller, 1988). The controlling shear zones are viewed as denudational fault systems (Armstrong, 1972) that accommodated crustal attenuation and served to unroof midcrustal rock masses (Lister and Davis, 1989).

The integrated shear systems are envisioned as grading from brittle behavior near the surface to ductile behavior at depth. Cenozoic mylonitic fabrics are inferred to have formed at deep structural levels, where they overprinted earlier fabrics formed during Mesozoic or older tectonism. As originally deep-seated rocks were brought toward the surface by continued slip along the evolving shear zones, mylonitic fabrics were in turn overprinted by brittle deformation and hydrous alteration. Eventually, the mylonitic core rocks were placed in contact with unmetamorphosed cover rocks along gently inclined detachment surfaces marked by flinty microbreccia and clayey fault gouge. These interpretations imply that mylonitic deformation occurred within ductile intracrustal shear zones that represented downdip continuations of precursors (Spencer and Reynolds, 1989b) of the brittle detachment faults now exposed at the surface.

Cordilleran metamorphic core complexes can be divided into three geographic groups (Fig. 3A) having different net directions of Cenozoic extension, as reflected by local trends of mylonitic lineation (Wust, 1986b). For the southern group, within and near southern Arizona, the orientation was $\mathrm{S} 60^{\circ} \mathrm{W}-\mathrm{N} 60^{\circ} \mathrm{E}$, which is also the observed trend of mylonitic lineation in the Catalina core complex (Fig. 2).

The timing of Cenozoic extension associated with the development of core complexes varied from north to south. In the northern group and the northernmost Pioneer core complex of the central group (Wust, 1986a), the dominant extensional deformation was early to middle Eocene in age (Parrish and others, 1988). This timing was coincident with a general resurgence in arc magmatism throughout the interior of the Pacific Northwest (Armstrong, 1974, 1988). Farther south, resumption of arc magmatism and coeval development of related metamorphic core complexes was delayed until mid-Tertiary (Oligocene to Miocene) time (Armstrong, 1990).

Metamorphic core complexes in southern Arizona form a varied subgroup (G. H. Davis, 1980; Rehrig and Reynolds, 1980) that occupies a belt nearly $500 \mathrm{~km}$ long (Fig. 3B), trending $\mathrm{N} 60^{\circ} \mathrm{W}$ at a high angle to the prevailing $\mathrm{N} 60^{\circ} \mathrm{E}$ direction of extension. Throughout the belt, the orientations of tilted fault blocks in cover strata outside the metamorphic cores correlate well with the tectonic vergence of nearby core complexes (corecomplex vergence is the inferred direction of tectonic transport of cover strata with respect to core rocks). Arrays of fault blocks define tilt domains (Fig. 3B) within which fault blocks are systematically backtilted with respect to core-complex vergence (Spencer and Reynolds, 1986, 1989c). The Catalina core complex is the only major one in the subgroup for which vergence was southwesterly instead of northeasterly. Along much of the rest of the belt, deep-seated rocks of the mylonitic cores can be viewed as having been extracted tectonically from beneath the Transition Zone flanking the Colorado Plateau to the northeast (Reynolds and Spencer, 1985; Spencer and Reynolds, 1989c). The South Mountain core complex (Reynolds, 1985) near Phoenix is notable because it displays a mylonitic fabric that has been imposed upon granitic rock emplaced in the crust during mid-Tertiary time, and thus provides evidence that mid-Tertiary deformation involved ductile strain.

\section{Catalina core complex}

The term "Catalina core complex" is adopted here, after Rehrig and Reynolds (1980), in preference to several more cumbersome names used by others (Dickinson and Shafiqullah, 1989). Plutonic and metamorphic core rocks range in age from early Proterozoic to mid-Tertiary, and form nearly contiguous exposures that occupy much of the Tortolita, Santa Catalina, and Rincon mountains (Figs. 2 and $3 \mathrm{C}$ ). Mylonitic gneiss displays 


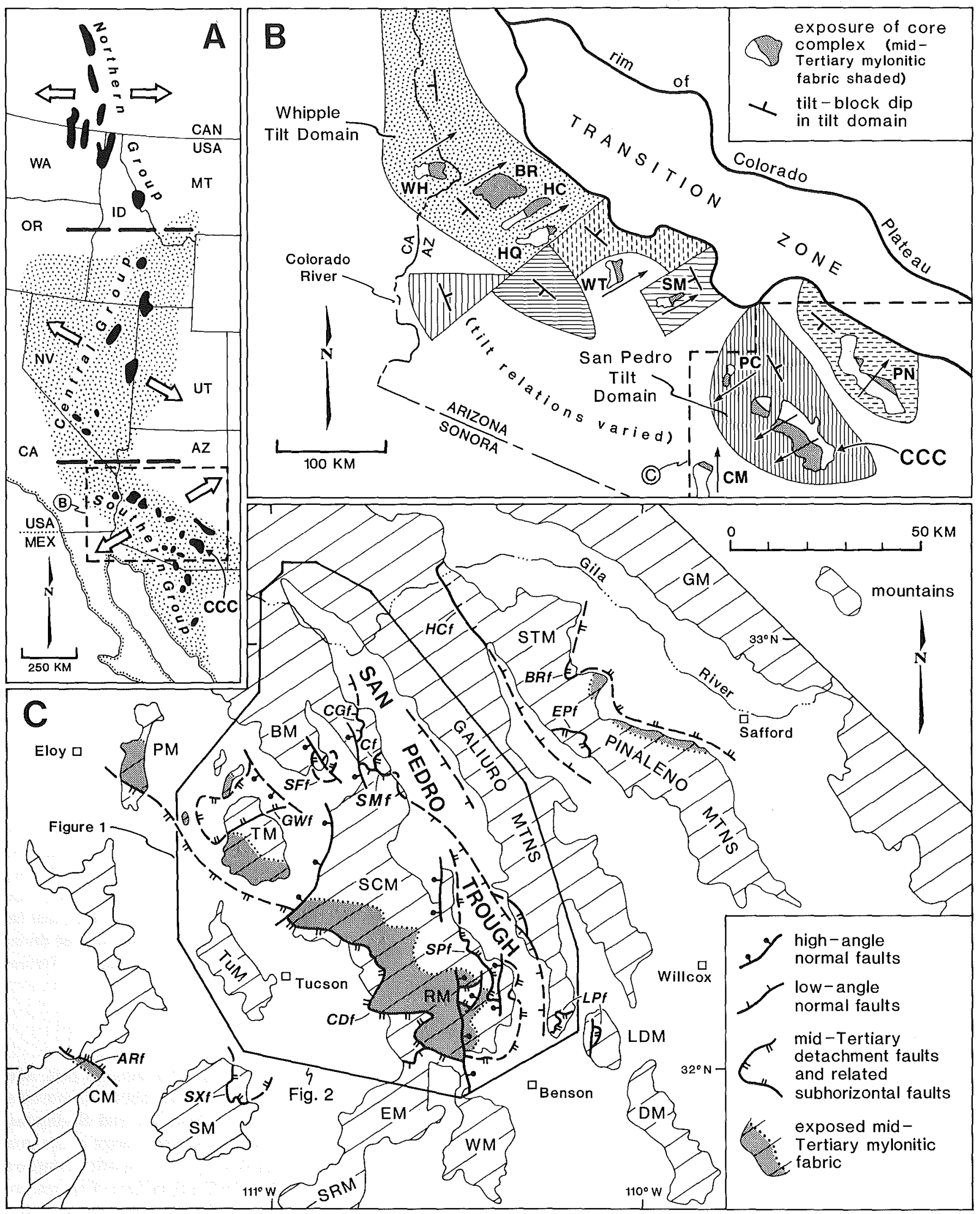


foliation dipping gently off the southwest flank of the complex (Banks, 1980), coherent lineation plunging S55 to $65^{\circ} \mathrm{W}$ (Fig. 2), and consistent S-C fabrics (Simpson and Schmid, 1983; Lister and Snoke, 1984) indicative of downdip shear vergence (top over bottom) toward the southwest (Fig. 4).

The gently dipping detachment fault system, which places cover strata against mylonitic rocks along the flank of the complex, extends along tectonic strike (N50 $\left.{ }^{\circ} \mathrm{W}\right)$ for about $125 \mathrm{~km}$ from Cienega Gap at the south end of the Rincon Mountains to Picacho Peak at the south end of the Picacho Mountains (Figs. 2 and 3C). The curvilinear trace of the detachment fault along the foot of the Santa Catalina and Rincon mountains reflects an undulatory fault configuration. Plunging antiformal arches and intervening synformal troughs are oriented subparallel to mylonitic lineation in core rocks beneath the detachment fault (G. H. Davis and Hardy, 1981).

At Picacho Peak, tilted mid-Tertiary volcanic rocks that abut downdip against the detachment fault (Shafiqullah and others, 1976) underwent severe alteration during displacement, and are now K-rich metasomatites (Brooks, 1986; Kerrich and Rehrig, 1987). Such metasomatism has not been reported elsewhere in association with the Catalina detachment system but may well be widespread, for K-metasomatism promoted by circulating basinal brines or hydrothermal leaching of basement rocks is common near other detachment systems (Chapin and Lindley, 1986; Glazner, 1988; Roddy and others, 1988). Elsewhere in Arizona, hydrothermal circulation promoted by the perturbation

Figure 3. Regional tectonic setting of Catalina core complex (CCC) and San Pedro trough (adjacent on the northeast). A: Schematic distribution of northern, central, and southern groups (delimited by heavy dashed lines) of Cordilleran metamorphic core complexes (solid) in relation to Basin and Range province (stippled). Arrows indicate net direction of crustal extension for each group modified after Wust (1986b). B: Diagrammatic tectonic relations of metamorphic core complexes (see legend) and key tilt domains (variably textured) in southern Arizona. Arrows indicate relative motion of upper or cover plates of core complexes as inferred from S-C and related fabrics in mid-Tertiary mylonitic gneisses below associated detachment faults. Other core complexes shown (in addition to $\mathrm{CCC}$ ): $\mathrm{BR}$, Buckskin-Rawhide; CM, Coyote Mountains; HC, Harcuvar; HQ, Harquahala; PC, Picacho; PN, Pinaleno; SM, South Mountain; WH, Whipple; WT, White Tank. Modified after Rehrig and others (1980), Rehrig (1986), and Spencer and Reynolds $(1986,1989 a, 1989$ c). C: Patterns of major extensional faults near Catalina core complex (occupying Tortolita, Santa Catalina, and Rincon Mountains) and adjacent San Pedro trough. Key faults: ARf, Ajo Road; BRf, Black Rock; Cf, Cloudburst; CDf, Catalina (main detachment); CGf, Camp Grant; EPf, Eagle Pass; GWf, Guild Wash; HCf, Hawk Canyon; LPf, Lime Peak; SFf, Star Flat; SMf, San Manuel; SPf, San Pedro; SXf, San Xavier. Selected mountain ranges: BM, Black; CM, Coyote; DM, Dragoon; EM, Empire; GM, Gila; LDM, Little Dragoon; PM, Picacho; SCM, Santa Catalina; SM, Sierrita; SRM, Santa Rita; STM, Santa Teresa; RM, Rincon; TM, Tortolita; TuM, Tucson; WM, Whetstone. Modified after Spencer and Reynolds (1989c); base data from Figure 1, Banks (1980), Blacet and Miller (1978), Cooper (1960, 1973), G. H. Davis and Hardy (1981), Dickinson (1984), G. H. Davis and others (1987a, b), Simons (1987), Naruk (1986, 1987a), and Yeend (1976).

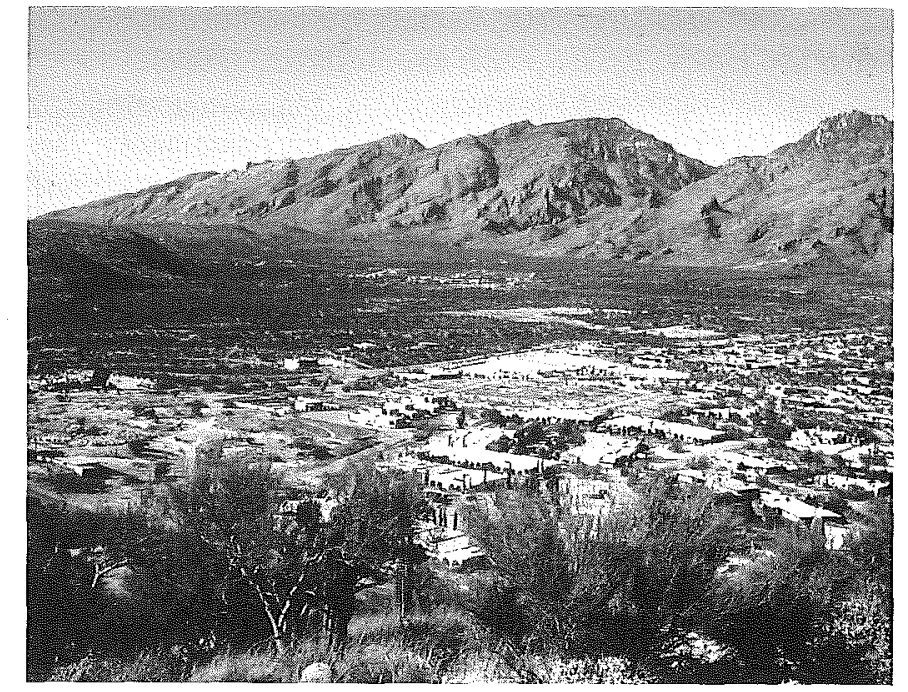

Figure 4. Oblique view northwest across northern edge of Tucson Basin showing prominent flatirons of foliated mylonitic gneiss dipping gently southwest off steep topographic front of Catalina forerange along flank of Catalina core complex; break in slope marks trace of Catalina detachment fault separating cover rocks beneath basin fill on left from core rocks exposed in rugged highlands of Santa Catalina Mountains on right.

of geotherms during tectonic denudation was also responsible for some metallic ore deposition (Spencer and Welty, 1986) in close spatial and temporal association with detachment faulting (Spencer and Welty, 1989).

The Catalina core complex occupies part of the San Pedro tilt domain (Fig. 3B), within which tilted homoclines of midTertiary volcanosedimentary sequences and underlying preTertiary strata strike $\mathrm{N} 20^{\circ}$ to $40^{\circ} \mathrm{W}$, at right angles to the trend of mid-Tertiary mylonitic lineation in the core complex, and dip northeast, opposite to the vergence of S-C fabrics in mid-Tertiary mylonitic gneiss of the core (Spencer and Reynolds, 1986, 1989c). Both northeast and southwest of the Catalina core complex and the San Pedro tilt domain, shear vergence in smaller core complexes, inclinations of associated detachment faults, and tilts of rotated fault blocks differ from the Catalina pattern, partly in orientation and partly in sense (Figs. 3B and C). The contrast implies either diachronous or heterogeneous crustal deformation during regional extension.

Nearby structures. To the northeast, mylonitic lineation along the flank of the Pinaleno core complex (Figs. 3B and C) plunges $\mathrm{N} 40^{\circ} \mathrm{E}, \mathrm{S}-\mathrm{C}$ fabrics in the mylonitic rocks reflect downdip shear vergence toward the northeast, and tilted homoclines of mid-Tertiary cover strata strike $\mathrm{N} 50^{\circ} \mathrm{W}$ and dip 40 to $60^{\circ}$ southwest (Blacet and Miller, 1978; G. H. Davis and Hardy, 1981; Naruk, 1986, 1987a; Simons, 1987). The Galiuro Mountains between the Catalina and Pinaleno core complexes (Fig. 3C) are capped by mid-Tertiary volcanic rocks dipping gently eastward (Figs. 1 and 2), and apparently represent a strip of relatively untilted and unextended ground separating faulted ex- 
tensional domains of opposing vergence lying to either side $(G . H$. Davis and Hardy, 1981; Spencer and Reynolds, 1989c).

To the southwest, downdip shear vergence is northerly (G. H. Davis and others, 1987a) in mylonitic rocks that structurally underlie the north-dipping Ajo Road detachment fault in the Coyote Mountains (Figs. 3B and C). In the nearby Sierrita Mountains, the subhorizontal San Xavier fault (Fig. 3C) displaces copper orebodies in its upper plate 10 to $12 \mathrm{~km} \mathrm{NNW}$ with respect to their counterparts in the lower plate (Langlois, 1978; Barter and Kelly, 1982; Jansen, 1982). Associated homoclines of mid-Tertiary Helmet Fanglomerate (Cooper, 1960, 1973 ) in the upper plate strike ENE, at right angles to the vector of fault displacement, and dip SSE, opposed to the direction of transport of the upper plate with respect to the lower plate. Subsidiary faults show that the San Xavier fault was the basal structure of a multiplated imbricate system. Fanning of bedding dips, which generally decrease up-section within syntectonic Helmet Fanglomerate, indicates that coarse mid-Tertiary clastic strata and an intercalated andesitic lava flow accumulated within an evolving rotational basin. Development of the basin was controlled by movements on the San Xavier fault system (King, 1982).

\section{San Pedro trough}

The term "San Pedro trough" is adapted here from oral usage developed by J. D. Lowell and his associates during his classic study of the tilted San Manuel and Kalamazoo porphyry copper orebodies north of the Catalina core complex (Lowell, 1968). The San Pedro trough is an elongate structural depression flanked on the southwest by the Catalina core complex and associated uplands lying farther north, and bounded on the northeast by the faulted range fronts of the relatively undeformed Galiuro and Dripping Spring mountains. These two ranges border contiguous trough segments occupied by reaches of the San Pedro and Gila rivers (Figs. 2 and 3C). Tilted homoclines of mid-Tertiary strata are extensively exposed along the edges of the San Pedro trough, where they lie unconformably beneath erosional remnants of younger Cenozoic basin fill, and are also exposed locally in eroded uplands of varied character lying farther to the southwest (Fig. 2).

The San Pedro trough contains undeformed post-midMiocene basin fill that overlies a complexly corrugated paleotopography of asymmetric tilt-blocks, which separate buried half-grabens of tilted mid-Tertiary strata. The pre-mid-Miocene fault blocks are tilted to the northeast and homoclinal strata within the associated half-grabens dip northeast. Erosional remnants of similar tilt-blocks and half-grabens are exposed at intervals across the more dissected uplands lying southwest of the San Pedro trough. Across the uplands, younger unconsolidated beds roughly equivalent in age to the basin fill of the San Pedro trough occur locally as discontinuous cover unconformably capping eroded tilt-blocks and half-grabens.

Along the trend of the San Pedro trough, prominent low- angle normal faults (Figs. 2 and 3C) dip southwest beneath the Catalina core complex and offset faults interpreted as strands of the Catalina detachment system. Fanning of dips in associated mid-Tertiary strata indicates that at least some of the low-angle normal faults were mid-Tertiary growth faults. An analogous low-angle normal fault system, but with northeast dip, is present northeast of the Galiuro Mountains adjacent to the Pinaleno core complex (Spencer and Reynolds, 1989c). The two low-angle normal fault systems dip beneath the rear flanks of the two core complexes with attitudes comparable to those of the detachment faults dipping off the frontal or mylonitic flanks of the same core complexes. The two detachment systems and the somewhat younger structures that offset each of them can be viewed as two generations of low-angle normal faults that had updip surface traces or headwall ruptures along or near the flanks of the intervening Galiuro Mountains block.

\section{Geologic history}

Geologic relations exposed within the study area record aspects of the varied tectonic history of southern Arizona through geologic time (Fig. 5). Located near the southwest extremity of the Precambrian continental block, the region was influenced by Phanerozoic events along both the Cordilleran and Mesoamerican continental margins (Dickinson, 1989). Observed structures reflect the cumulative effects of numerous superposed deformations of different character and orientation (G. H. Davis, 1981).

Early to middle Proterozoic construction of typical continental crust was followed by a lengthy period of late Proterozoic and Paleozoic platform sedimentation punctuated by intervals of nondeposition and modest erosion. Multiple diastems and disconformities represent varying lengths of time for which section is missing. In late Paleozoic time, the study area lay within the foreland region of the Ouachita orogenic system but the site was then part of the Pedregosa shelf and forebulge, hence too distal to participate in significant foreland downflexure (Armin, 1987).

Arc magmatism related to subduction along the Cordilleran margin was initiated in Mesozoic time. Thin volcaniclastic sequences of mid-Mesozoic age are preserved locally, but no Phanerozoic plutons older than latest Cretaceous in age are known within the study area. Sedimentation in the rifted midJurassic to mid-Cretaceous Bisbee Basin, which connected structurally through the Chihuahua Trough into the nascent Gulf of Mexico, reached into the study area from the southeast (Dickinson and others, 1987b, 1989). The feather edge of the Upper Cretaceous sediment prism deposited in the Rocky Mountain retroarc foreland basin also extended into the study area from the northeast, as the local Pinkard Formation.

Laramide magmatism and orogenic deformation in latest Cretaceous and early Tertiary time left the most pervasive imprint on local rock assemblages prior to mid-Tertiary magmatism and taphrogenic deformation. The recognition that separate Laramide and mid-Tertiary events are recorded by two distinct peaks of arc magmatism in southern Arizona (Damon and Bikerman, 1964; 


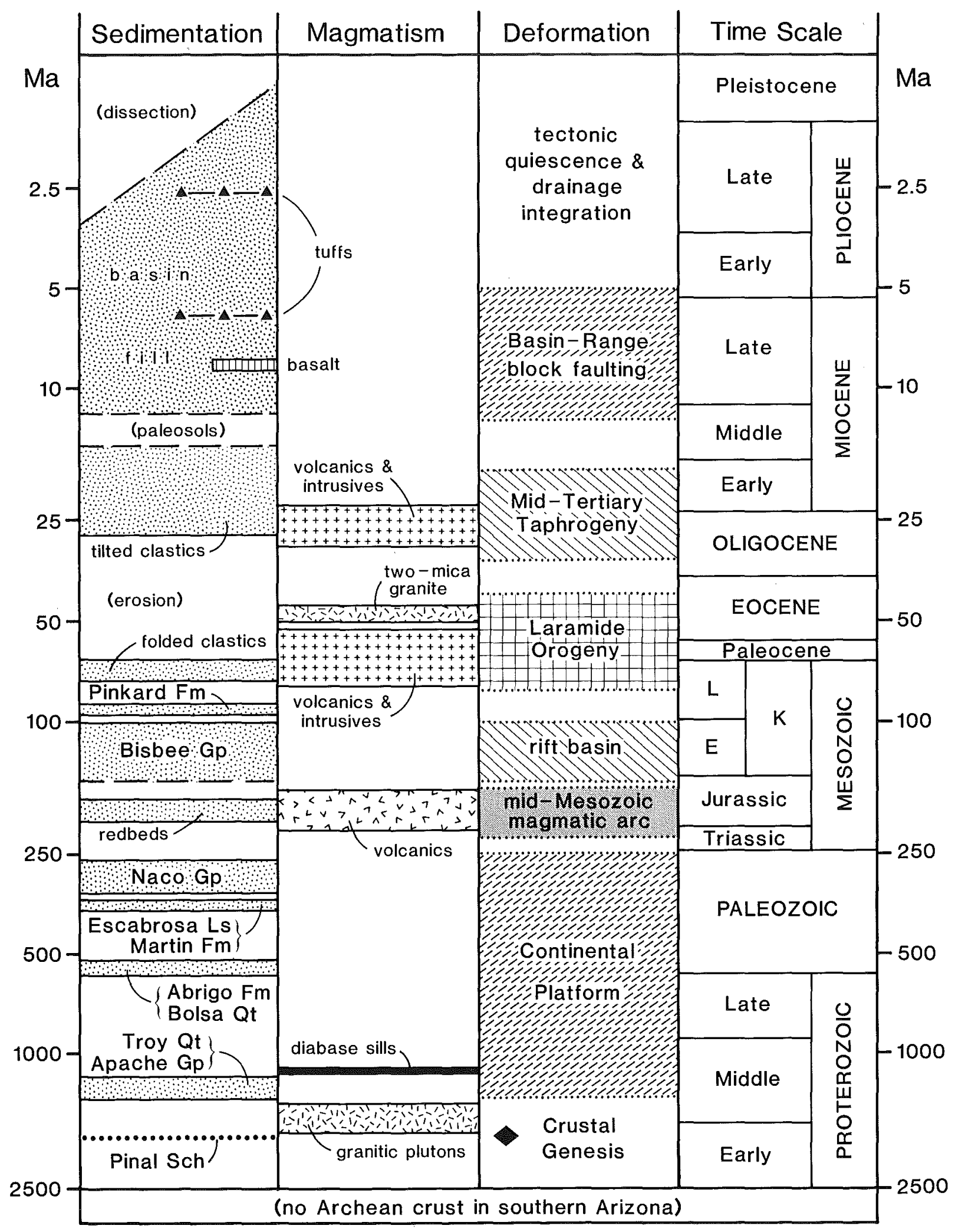

Figure 5. Salient episodes of geologic history in the region of the Catalina core complex and San Pedro trough modified after Coney (1978), Reynolds (1980), and Dickinson (1981). Note logarithmic time scale in Ma; geologic time scale after Palmer (1983). Ages of tuffs in Cenozoic basin fill after Scarborough (1975); slightly older basalt shown with basin fill actually occurs on The Tablelands of the northern Galiuro Mountains (Shafiqullah and others, 1980). 
Damon and others, 1964) was an insight fundamental to our present understanding of regional geologic history. The inference that a widespread Eocene erosion surface developed throughout much of southern Arizona during the interval between the two magmatic pulses is a basic corollary concept (Livingston and others, 1968). Later structural analysis based on the average strikes of Laramide and mid-Tertiary dike swarms showed that Laramide contraction and mid-Tertiary extension were both oriented ENE-WSW, and thus reflected sharply contrasting tectonic regimes (Rehrig and Heidrick, 1976).

A provisional plate tectonic rationale for the discrete Laramide and mid-Tertiary magmatic and deformational episodes (Fig. 6) has been derived from consideration of the inferred behavior of a subducted slab of oceanic lithosphere descending beneath the Cordilleran region from an evolving trench system along the Pacific continental margin (Coney and Reynolds, 1977; Dickinson and Snyder, 1978; Keith, 1978, 1982; Dickinson, 1981):

(a) In latest Cretaceous to Paleogene time, progressive flattening of the angle of slab descent is inferred to have caused the locus of slab-induced melting to shift gradually inland beneath the continent until the belt of arc magmatism migrated through Arizona, from coastal regions farther west, to produce the Laramide pulse of local magmatism; concurrently, enhanced plate coupling by shear interaction between the subhorizontally subducted slab and the overriding continental lithosphere promoted contraction and crustal thickening to produce the Laramide episode of orogenic deformation.

(b) In mid-Tertiary time (Eocene-Oligocene boundary to mid-Miocene), renewed steepening of the angle of slab descent caused arc magmatism to migrate back through Arizona, to produce the mid-Tertiary pulse of local magmatism as the site of melting in the subjacent mantle swept back toward the continental margin; concurrently, reduced coupling between the subducted slab, which was no longer in direct contact with the overriding continental plate, allowed extension and crustal thinning to produce the mid-Tertiary episode of taphrogenic deformation.

Extensional deformation continued within the Basin and Range province of southern Arizona after mid-Miocene time, but the widespread tectonic denudation characteristic of mid-Tertiary deformation was supplanted by high-angle normal faulting. Net post-Laramide crustal thinning in southern Arizona has reduced the crustal thickness within the Basin and Range province to 22.5 to $25 \mathrm{~km}$, as opposed to 40 to $42.5 \mathrm{~km}$ (Sinno and others, 1981) or 50 to $52.5 \mathrm{~km}$ (Hauser and Lundy, 1989) beneath the Colorado Plateau to the north (Spencer and Reynolds, 1986, 1989c). Northward transport of gravelly sediment across the present plateau rim, from higher paleotopography farther south during Eocene time (Potochnik, 1989), implies that the Laramide crust in southern Arizona was once even thicker than that of the Colorado Plateau, hence perhaps twice as thick as it is now.

Filling of modern basins of the Basin and Range province with gently dipping or undeformed sediment began by late Mio- cene time (Scarborough and Peirce, 1978). During Pliocene time, dissection of basin fill in a number of structural depressions, including the San Pedro trough, began as the Gila River drainage system was integrated into the nascent Gulf of California. A wide variety of Pleistocene and Holocene alluvial deposits mantle basin fill and mask the flanks of adjacent uplands to varying degrees from place to place. These include active fans and pediments, floodplain alluvium, and dissected terraces formed by incision of somewhat older fans, pediments, and floodplains.

\section{Plan of this paper}

Before systematic treatment of mid-Tertiary and younger stratigraphic sequences and their structural relations within the study area, the following topics are addressed in order: (a) a summary of pre-Laramide rock assemblages as background for considering Tertiary history, (b) the nature of key Laramide events and their significance for later structural evolution, (c) regional Tertiary tectonomagnetic patterns as the context for syntectonic mid-Tertiary sedimentation, (d) the geometry of the Catalina detachment system and the timing of tectonic denudation of the Catalina core complex, and (e) a discussion of alternate structural models for detachment systems. Closing passages present a conceptual synthesis of local structural evolution during mid-Tertiary taphrogenic deformation.

\section{PRE-LARAMIDE ROCK ASSEMBLAGES}

Varied pre-Laramide rock assemblages form the substratum upon which most mid-Tertiary volcanosedimentary successions of the study area were deposited. Precambrian basement is overlain by mid-Proterozoic to mid-Cretaceous sedimentary strata that were not strongly deformed or metamorphosed prior to Laramide orogenic events. The aggregate stratigraphic thickness of the sedimentary cover, as reconstructed for Late Cretaceous time, ranges from 2,500 to $4,000 \mathrm{~m}$, averaging perhaps 3,000 to 3,500 $\mathrm{m}$. Basement rocks include intensely deformed and variably metamorphosed lower Proterozoic strata intruded by voluminous lower and middle Proterozoic granitic plutons. The overlying stratigraphic section includes three principal components: (a) middle Proterozoic strata intruded by middle Proterozoic diabase sills, (b) widespread Paleozoic formations broken by multiple erosional disconformities, and (c) several Mesozoic sequences of varied origin and more restricted distribution. The most lengthy hiatus present locally is the interval representing more than 500 m.y. between Proterozoic and Paleozoic sedimentation.

\section{Precambrian basement}

The oldest rocks present in the study area are turbidites and minor volcanics of the lower Proterozoic Pinal Schist, which was deformed and metamorphosed under greenschist metamorphic conditions prior to emplacement of the Proterozoic granitic plutons. Local occurrences are part of the western assemblage of Pinal Schist in southern Arizona (Copeland and Condie, 1986); 


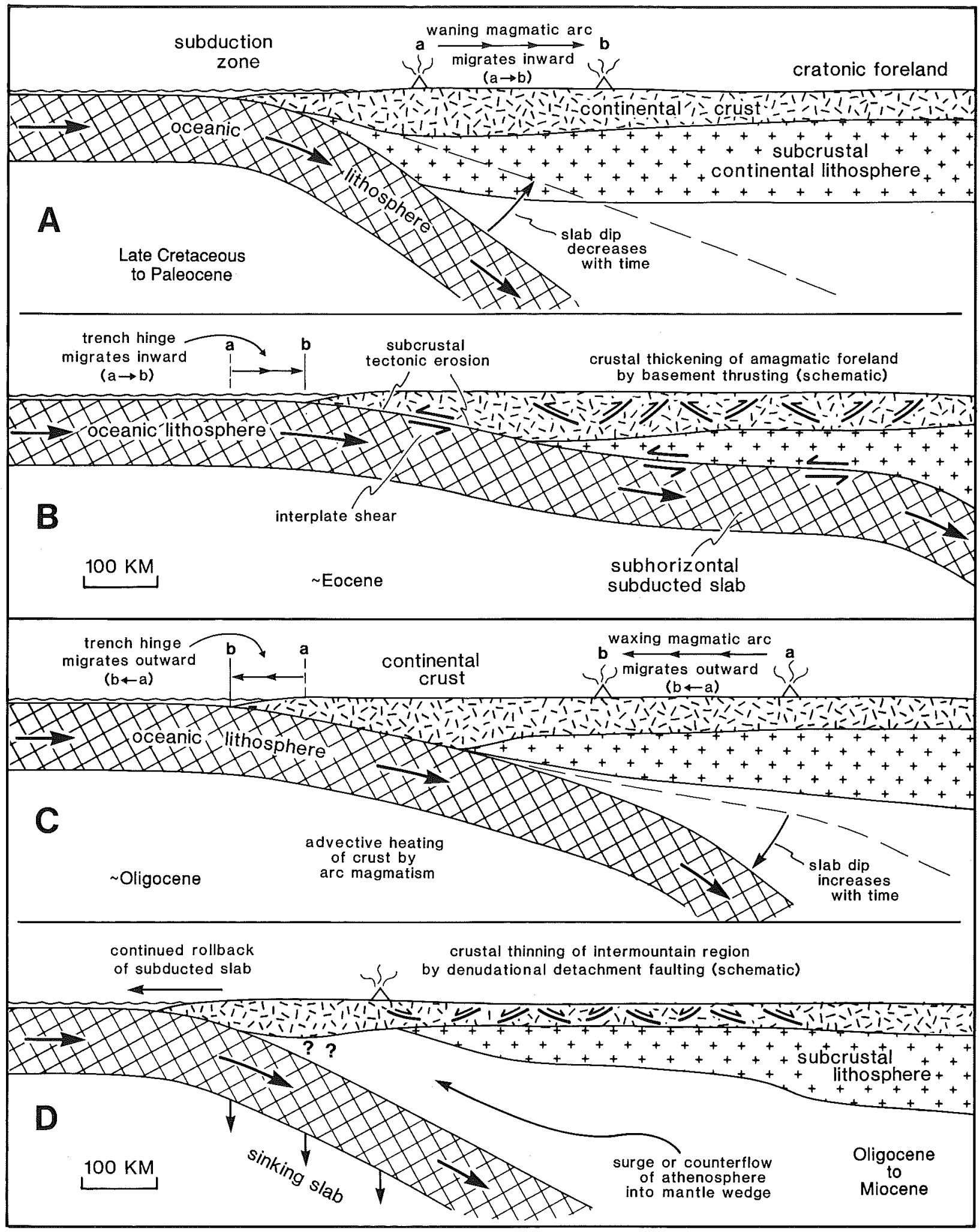

Figure 6. Inferred plate tectonic setting of Laramide and mid-Tertiary deformation in southern Arizona: sequence $A$ to $B$ depicts progressive development of Laramide orogenesis and sequence $C$ to $D$ depicts subsequent development of mid-Tertiary taphrogenesis. Discussions in text amplify concepts illustrated. Recent analysis (Stock and Molnar, 1988) indicates that the Farallon oceanic plate was being subducted during early Laramide orogenesis (A) but that after $\sim 55$ Ma the derivative Vancouver plate was being subducted during later Laramide orogenesis and mid-Tertiary taphrogenesis (B-D). 
quartzolithic turbidite sandstones reflect a complex orogenic provenance (Condie and DeMalas, 1985; Swift, 1987). Typical outcrops are intercalated metagraywacke semischist and pelitic slate or phyllite. Exposures in the Johnny Lyon Hills at the southeast extremity of the study area (Fig. 2), and in the adjacent Little Dragoon Mountains still farther east (Fig. 3C), were described by Cooper and Silver (1964), but numerous exposures elsewhere (Fig. 7) have not been studied in detail. Original depositional features are locally preserved intact, but metamorphic fabrics are generally dominant and contact metamorphism has commonly overprinted older textures near the margins of both Precambrian and Phanerozoic plutons. Internal structures characteristic of mélange and broken formation imply that initial deformation occurred within an accretionary prism of oceanic strata developed within a Proterozoic subduction zone (Swift, 1987). This interpretation is supported by the occurrence locally of lenses of metavolcanic rock having the geochemical signature of oceanic basalt (Copeland and Condie, 1986). In the Little Dragoon Mountains just outside the study area, intrusive metarhyolite younger than the mélange fabric (Swift, 1987) has yielded a U-Pb age of approximately $1700 \mathrm{Ma}$ (Reynolds and others, 1986a, \#1597).

The continuity of the Pinal Schist terrane was disrupted by emplacement of voluminous granitic plutons (Table 1) that form the bulk of the local Precambrian basement (Fig. 7). Most widespread are rocks of the Oracle/Ruin suite of porphyritic granite with subhedral K-feldspar phenocrysts set in a buff or tawny groundmass of coarse granular texture. Previous workers have mapped this lithology as either: (a) Oracle Granite, with type locality near Oracle (Fig. 7) at the northern tip of the Santa Catalina Mountains; or (b) Ruin Granite, with type locality in Ruin Basin near Miami (approximately $35 \mathrm{~km}$ north of the study area). Because the two units are lithologically indistinguishable (Schmidt, 1971; Keith and others, 1980), the names are combined here in recognition of alternate past usage. Studies to date have not defined the number of separate Oracle/Ruin plutons that might be present. Next most abundant areally are rocks of the Johnny Lyon suite of granular to seriate granodiorite, which may form a single composite pluton in the southeastern part of the study area. Small masses of finer-grained granodiorite and quartz diorite may represent mafic phases of the Oracle/Ruin intrusive suite, or may be older than either of the two main granitic suites. Most dark augen gneiss of the Catalina core complex was produced by mylonitic deformation of Oracle/Ruin protolith (Creasey and others, 1977; Banks, 1980; Keith and others, 1980).

The genesis of Precambrian crust within the study area occupied perhaps 325 m.y. of early to middle Proterozoic time, from before $1700 \mathrm{Ma}$ to nearly $1400 \mathrm{Ma}$. This interval spanned the time between initial consolidation of crustal materials into a profile of continental thickness and the emplacement of anorogenic granite (Anderson, 1983). A period of deep erosion that exposed Proterozoic plutons over wide areas preceded the preservation of any local sedimentary record.

\section{Proterozoic stratigraphy}

Scattered exposures of Apache Group and Troy Quartzite within the study area represent the southernmost outcrops of middle Proterozoic sedimentary strata that are more extensively exposed in central Arizona (Shride, 1967; Wrucke, 1989). Each of the Precambrian stratigraphic units (Table 2) is bounded by unconformities. The contacts all appear disconformable in outcrop, but slight angularity is demonstrated for each by regional relationships, and the areal distribution of each of the units listed is somewhat different. For example, Pioneer Shale laps out against basement in the Galiuro Mountains, Mescal Limestone is locally missing above Dripping Spring Quartzite, basalt above the Apache Group is discontinuous, Troy Quartzite is absent below Paleozoic strata south of exposures near Putnam Wash and Aravaipa Creek (Fig. 2), and erosion prior to Paleozoic time also stripped Dripping Spring Quartzite from parts of the study area (Cooper and Silver, 1964; Shride, 1967; Krieger, 1961, 1968a; Wrucke, 1989).

Deposition of the Proterozoic strata began at some undetermined time, perhaps $\sim 1250 \mathrm{Ma}$. It was complete prior to the intrusion of widespread diabase dikes and sills, which are virtually ubiquitous wherever the strata are exposed and which also cut underlying basement rocks. Diabase intrusions in the basement are generally confined to a zone that is structurally within 100 to $250 \mathrm{~m}$ of the stratigraphic base of the overlying Apache Group (Shride, 1967; Krieger, 1974a). The aggregate stratigraphic thickness of the Proterozoic section is $\sim 500 \mathrm{~m}$ (Table 2), but net thicknesses of associated diabase sills are comparable in many places and raise the total thickness of the combined rock assemblage upward toward a maximum of $\sim 1,000 \mathrm{~m}$.

A lens of red albite granophyre near the top of a diabase sill cutting the Pioneer Shale of the Apache Group in the Little Dragoon Mountains (Fig. 3C), which lie just east of the study area, has yielded a $\mathrm{Pb} / \mathrm{Pb}$ age of approximately $1100 \mathrm{Ma}$ (Reynolds and others, 1986a, \#1455). A number of K-Ar and U-Pb ages for comparable diabase sills in central Arizona north of the study area range from $1050 \mathrm{Ma}$ to $1150 \mathrm{Ma}$, but most are comparable to an age of $1100 \mathrm{Ma}$ when analytical uncertainties are taken into account (Silver, 1978; Reynolds and others, 1986a).

\section{Paleozoic stratigraphy}

Widespread Paleozoic strata in southern Arizona are dominantly marine units that range in age from Middle Cambrian to mid-Permian (Table 3), but all represent intermittent platform sedimentation that was repeatedly interrupted by multiple hiatuses (Fig. 5). Individual formational contacts are variously gradational, paraconformable, or disconformable (Bryant, 1968). The aggregate local thickness of perhaps $1,750 \mathrm{~m}$ of Paleozoic strata (Peirce, 1976) includes, on average, $250^{+} \mathrm{m}$ of Cambrian section, $250^{-} \mathrm{m}$ of mid-Paleozoic carbonate strata, and $1,250 \mathrm{~m}$ of upper Paleozoic (Pennsylvanian-Permian) Naco Group (Table 
Catalina core complex, southern Arizona

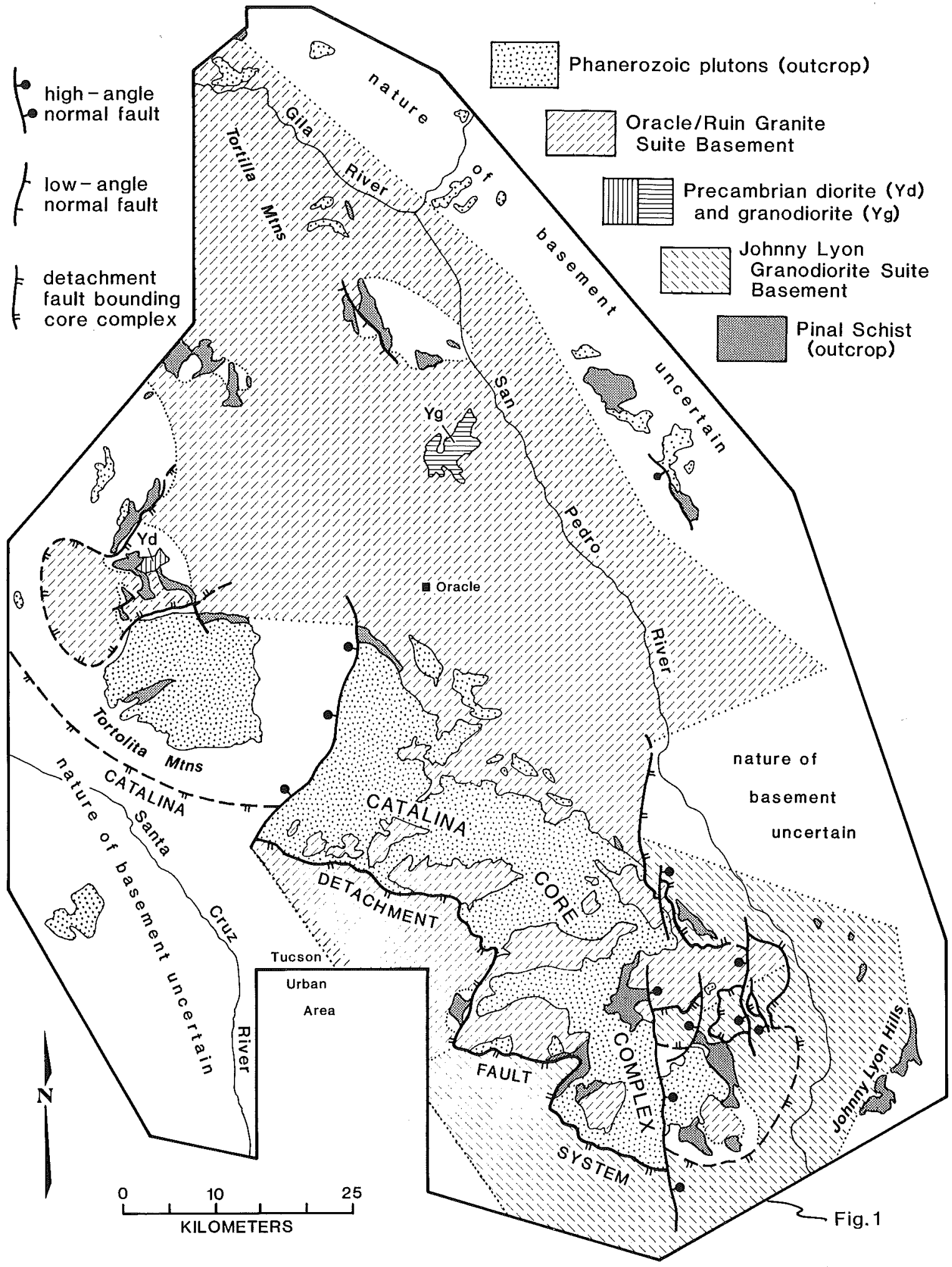

Figure 7. Distribution of Precambrian basement units and locations of Phanerozoic plutons within the study area; $\mathrm{Yd}$ (quartz diorite) and $\mathrm{Yg}$ (granodiorite) are quartzose and biotitic mafic bodies of uncertain Precambrian age and affinity (see text for discussion). 
TABLE 1. TERMINOLOGY, AGE, AND TYPICAL COMPOSITION OF PRECAMBRIAN GRANITIC ROCKS

\begin{tabular}{|c|c|c|c|}
\hline & $\begin{array}{l}\text { Johnny Lyon Granodiorite Suite } \\
\qquad\left(X \mid-X j m^{\star}\right)\end{array}$ & $\begin{array}{c}\text { Granodiorite and Diorite } \\
\text { [unnamed] } \\
\text { (Yg and } \mathrm{Yd} \text { ) }\end{array}$ & $\begin{array}{c}\text { Oracle/Ruin Granite Suite } \\
\text { (Yo-Yom*) }\end{array}$ \\
\hline $\begin{array}{l}\text { Component Plutonic } \\
\text { Bodies }\end{array}$ & $\begin{array}{l}\text { Johnny Lyon Granodiorite } \\
\text { (Cooper and Silver, 1964) of } \\
\text { Johnny Lyon Hills and eastern } \\
\text { flank of Rincon Mountains (Sil- } \\
\text { ver, 1978); "Rincon Valley Gran- } \\
\text { odiorite" of Drewes (1977) and } \\
\text { Keith and others (1980) south- } \\
\text { west of Rincon Mountains and of } \\
\text { Drewes (1974) and Thorman and } \\
\text { Drews (1981) in eastern Rincon } \\
\text { Mountains. }\end{array}$ & $\begin{array}{l}\text { Blotite granodiorite (Yg) of } \\
\text { Creasey (1965, 1967) in Black } \\
\text { Hills north of Oracle, and quartz } \\
\text { diorite }(\mathrm{Yd}) \text { of Banks and others } \\
(1977,1978) \text { north of Tortolita } \\
\text { Mountains. }\end{array}$ & $\begin{array}{l}\text { Exposures mapped previously } \\
\text { as either Oracle Granite of } \\
\text { Peterson (1938) or Ruin Granite } \\
\text { of Ransome (1903); "Continen- } \\
\text { tal Granodiorite" of Keith and } \\
\text { others (1980) including expo- } \\
\text { sures mapped by Drewes } \\
\text { (1977) as "Rincon Valley Gran- } \\
\text { odiorite" near Twin Hills in Tuc- } \\
\text { son at western base of Rincon } \\
\text { Mountains. }\end{array}$ \\
\hline Radiometric Ages & $\begin{array}{l}\text { Early Proterozoic U-Pb age (zir- } \\
\text { con from Johnny Lyon Hills) of } \\
\sim 1,625 \mathrm{Ma} \text { (Reynolds and oth- } \\
\text { ers, } 1986 \mathrm{a} \text { \#1581); K-Ar ages } \\
(\sim 1,570 \text {, hornblende, Rincon Val- } \\
\text { ley, west flank of Rincon Moun- } \\
\text { tains; } \sim 1,550 \text {, biotite, Happy Val- } \\
\text { ley, east flank of Rincon Moun- } \\
\text { tains) nearly concordant with } \\
\text { preferred U-Pb age when analyti- } \\
\text { cal uncertainties are taken into } \\
\text { account (Reynolds and others, } \\
\text { 1986a, \#1562 and \#1567). }\end{array}$ & $\begin{array}{l}\text { Middle Proterozoic K-Ar age of } \\
\sim 1,440 \mathrm{Ma} \text { for } \mathrm{Yd}(\mathrm{Reynolds} \text { and } \\
\text { others, 1986a, } \# 1540 \text { ) suggests } \\
\text { either that the rocks are mafic } \\
\text { phases of Oracle/Ruin Granite } \\
\text { suite or that intrusion of latter } \\
\text { plutons reset ages of local bod- } \\
\text { les analogous to Madera Diorite } \\
(\sim 25 \text { percent quartz) of Ran- } \\
\text { some (1903) in Pinal Mountains } \\
\text { where its K-Ar and } \mathrm{Rb}-\mathrm{Sr} \text { ages } \\
\text { range 1,625 to } 1,700 \mathrm{Ma} \\
\text { (Reynolds and others, } 1986 \mathrm{a} \text { ). }\end{array}$ & $\begin{array}{l}\text { Twelve middle Proterozoic ages } \\
\text { (K-Ar, Rb-Sr, U-Pb) for Oracle } \\
\text { Granite and Ruin Granite are } \\
\text { generally concordant, within } \\
\text { analytical uncertainty, in the } \\
\text { range } 1,420 \text { to } 1,450 \mathrm{Ma} \text { (Keith } \\
\text { and others, 1980; Reynolds and } \\
\text { others, 1986a); younger K-Ar } \\
\text { and Rb-Sr ages (1,390 to } 1,415 \\
\text { Ma) from exposures near Twin } \\
\text { Hills (see above) also concor- } \\
\text { dant when their large ( 50 Ma) } \\
\text { analytical uncertainties are } \\
\text { taken into account (Reynolds } \\
\text { and others, 1986a, \#1514, } \\
\text { \#1516, \#1521, \#1525). }\end{array}$ \\
\hline Composition ${ }^{\dagger}$ & Q-25, P-50, K-12, B-10, H-3 & $Q-25, P-55, K-8, B-12$ & $Q-30, P-30, K-30, B-10$ \\
\hline
\end{tabular}

*Where mylonitic.

${ }^{\dagger} \mathrm{Q}=$ quartz; $P=$ plagioclase $; \mathrm{K}=\mathrm{K}$-feldspar; $\mathrm{B}=$ biotite; $\mathrm{H}=$ hornblende.

3). Although much or all of the Naco Group was removed from parts of the study area prior to mid-Cretaceous time, remnants of most of its constituent formations are preserved locally in both the metamorphic core and the detached cover of the Catalina core complex (Drewes, 1974, 1977; Thorman and Drewes, 1981; Lingrey, 1982; Janecke, 1986).

\section{Mesozoic assemblages}

Pre-Laramide Mesozoic rocks include three disparate assemblages, none of which is extensively exposed within the study area: (a) mid-Mesozoic volcaniclastic redbeds, (b) the Bisbee Group of probable Early Cretaceous age, and (c) the Pinkard Formation of early Late Cretaceous age. Mesozoic sedimentation may have added $1,000 \mathrm{~m}$ or more of stratigraphic section to parts of the study area, but probably much less than that thickness was still present following extensive erosion prior to mid-Tertiary time.
Mid-Mesozoic volcaniclastic redbeds are represented by approximately $100 \mathrm{~m}$ of Walnut Gap Volcanics in the Johnny Lyon Hills (Cooper and Silver, 1964), and by approximately $500 \mathrm{~m}$ of Recreation Red Beds in the Tucson Mountains (Drewes, 1981). Lithologic correlations suggest that both units are of Early to Middle Jurassic age (Beatty, 1987). The Recreation Red Beds are intruded by a dike of andesite porphyry that has yielded a Late Jurassic K-Ar age of $155 \mathrm{Ma}$ (Reynolds and others, 1986a, \#1361). Jurassic granitic rocks present elsewhere in southern Arizona are apparently absent within the study area.

A number of structurally isolated exposures of the Bisbee Group, strongly deformed and partly metamorphosed, are present in the Rincon and southern Galiuro mountains in the southeastern part of the study area (Drewes, 1974, 1977; Thorman and Drewes, 1981; Grover, 1982; Lingrey, 1982; Dickinson, 1986; Goodlin and Mark, 1987). In the Tucson Mountains farther west, the Bisbee Group is apparently represented by a unit known locally as Amole Arkose (Risley, 1987). The northernmost out- 
TABLE 2. CHARACTERISTIC LITHOLOGY AND TYPICAL THICKNESS OF MIDDLE PROTEROZOIC STRATA

(Apache Group* and overlying Troy Quartzite)

\begin{tabular}{lcl}
\hline Formation & Meters & \multicolumn{1}{c}{ Dominant Lithology } \\
\hline Troy Quartzite & $120-200$ & $\begin{array}{l}\text { White to gray quartzite with inter- } \\
\text { calated fine conglomerate } \\
\text { Basaltic lava }\end{array}$ \\
Mescal Limestone & $60-100$ & $\begin{array}{l}\text { Porphritic amygdaloidal basalt, } \\
\text { single or multiple flows } \\
\text { Gray to pink cherty dolostone } \\
\text { with stromatolitic algal bio- } \\
\text { stromes }\end{array}$ \\
$\begin{array}{l}\text { Dripping Spring Quartzite } \\
\text { (basal Barnes Cg. Mem.) }\end{array}$ & $\begin{array}{c}105-215) \\
\text { Pioneer Shale }\end{array}$ & $\begin{array}{l}\text { Resistant brown to gray quart- } \\
\text { zite with intercalated thin silt- } \\
\text { stone intervals }\end{array}$ \\
(basal Scanlan Cg. Mem.) & $(0-5)$ & $\begin{array}{l}\text { Red to gray mudstone and silt- } \\
\text { stone with intercalated thin sand- } \\
\text { stone beds }\end{array}$ \\
Aggregate section & $\sim 500$ & $\begin{array}{l}\text { (intruded by diabase sills of } \\
\text { locally comparable thickness) }\end{array}$ \\
\hline
\end{tabular}

*Apache Group includes Pioneer Shale, Dripping Spring Quartzite, Mescal Limestone, and overlying basalt.

crops of Bisbee Group occur along the eastern flank of the Santa Catalina Mountains where local structural relations imply deposition adjacent to a paleofault (Janecke, 1986, 1987), which may have marked the northern edge of the Bisbee Basin. Although further work is needed in all local exposures to establish the thickness and lithologic order of strata within the Bisbee Group, approximately $1,000 \mathrm{~m}$ of section may have been present prior to Laramide deformation and subsequent erosion (Bilodeau and Lindberg, 1983; Risley, 1987). Complex nonmarine interfingering of conglomeratic beds, sandstone packets, and finer-grained clastic intervals is characteristic; shaly intervals include both red floodplain mudstone and dark lacustrine deposits. Although the Bisbee Group in southern Arizona ranges from Late Jurassic to mid-Cretaceous in age, sequences exposed within the study area are probably Lower Cretaceous strata based on lithologic analogies with counterparts exposed elsewhere (Dickinson and others, 1989).

Approximately $100 \mathrm{~m}$ of Upper Cretaceous Pinkard Formation, mainly massive cross-bedded sandstone, is exposed locally beneath mid-Tertiary volcanic cover along the western escarpment of the Galiuro Mountains north of Aravaipa Creek (Krieger, 1968c). These Cenomanian or Turonian strata record marginal marine sedimentation near the strandline of the Cretaceous interior seaway (Molenaar, 1983).

\section{LARAMIDE GEOLOGIC FEATURES}

In keeping with traditional usage farther north (Spieker, 1946), the term "Laramide" has long been applied in southern Arizona to rocks and structures associated with orogenic deformation during latest Cretaceous and Paleogene time (Keith,
1984). This usage is continued here for two reasons: (a) local deformation of Laramide age was generally coeval with, and is inferred to have been broadly cogenetic with, the classic Laramide orogeny of the nearby central Rocky Mountain region (Dickinson and others, 1988); and (b) recognition of a group of related Laramide rock assemblages and structural features that formed during latest Cretaceous and earliest Tertiary deformation is straightforward within the study area, but distinction between Cretaceous and Tertiary facets of that deformational episode is commonly uncertain. The term "Laramide" is thus convenient shorthand to designate geologic events that have clearcut significance for local relations but jointly span the Cretaceous-Tertiary time boundary. Understanding the structural relations of Laramide assemblages within the study area is important to allow effects of Laramide deformation to be distinguished from features of mid-Tertiary origin. Keith and Wilt (1986) have recently subdivided Laramide structures and rock assemblages of southern Arizona into several subgroups based partly on age and partly on geometry, but the utility of this approach is as yet untested by others and no attempt is made here to subdivide Laramide events in a formal way.

\section{Laramide orogeny}

The overall geometric configuration of structures developed during Laramide deformation in southern Arizona is controversial. The presence of tight folds and thrust faults is uncontested, but the lateral extent of individual thrust sheets is debated (Dickinson, 1984). For southeast Arizona, G. H. Davis (1979) argued that Laramide thrusts and reverse faults of variable vergence root locally along the flanks of basement-cored uplifts, and recent work in adjacent southwest New Mexico has documented similar structural relations (Seager and Mack, 1986). In this view, favored here (cf., Dickinson, 1981), the chief mode of Laramide deformation produced structural features similar in tectonic style to those in the classic Laramide province of the central Rocky Mountains.

Drewes $(1976,1978,1981)$ argued, however, that major Laramide faults in southeast Arizona are segments of a deformed megathrust system with a regionally subhorizontal attitude. He inferred aggregate lateral slip of more than $100 \mathrm{~km}$, with the upper plate overthrust toward the northeast (or NNE). In southwestern Arizona, where somewhat deeper structural levels are exposed, Haxel and others (1984) concluded that synmetamorphic thrusts are widespread as undulatory but roughly subhorizontal structures. Keith and Wilt (1985) inferred that these deep-seated structures formed part of a regionally extensive Laramide thrust system along which the lower plate was underthrust toward the northeast (or NNE) for perhaps $100 \mathrm{~km}$ or more. The relative merit of these alternate ideas that appeal to massive lateral transport of extensive Laramide thrust sheets remains unresolved.

Orientations of mesoscopic Laramide structures in southern Arizona and adjoining areas are compatible with geodynamic stresses imposed by subhorizontal subduction of an oceanic slab 
TABLE 3. GENERAL LITHOLOGY, AGE, AND TYPICAL THICKNESS OF PALEOZOIC STRATIGRAPHIC UNITS

(Naco Group and underlying formations)

\begin{tabular}{|c|c|c|c|}
\hline Formation & Age & Meters & General Lithology \\
\hline Concha Limestone* & Mid-Permian & $50-100$ & Massive gray cherty limestone \\
\hline Scherrer Formation & Mid-Permian & $175-225$ & Quartzite with middle limestone member \\
\hline Epitaph Dolomite & Early Permian & $50-250$ & Interbedded dolostone and redbeds \\
\hline Colina Limestone & Early Permian & $75-125$ & Massive gray to black limestone \\
\hline \multirow[t]{2}{*}{ Earp Formation } & Early Permian to & & \\
\hline & Late Pennsylvanian & $225-325$ & Interbedded limestone and sandstone \\
\hline \multirow[t]{2}{*}{ Horquilla Limestone } & Middle to Late & & \\
\hline & Pennsylvanian & $300-475$ & Limestone with intercalated shale \\
\hline Black Prince Limestone $^{\dagger}$ & Early Pennsylvanian & $50-75$ & Limestone with basal reddish regolith \\
\hline \multirow[t]{2}{*}{ Total Naco Group } & Pennsylvanian- & & \\
\hline & Permian & $-1,250$ & (Marine and marginal marine) \\
\hline \multirow[t]{2}{*}{ Escabrosa Limestone } & Early to Middle & & \\
\hline & Mississippian & $125-175$ & Massive gray cherty limestone \\
\hline \multirow{3}{*}{$\begin{array}{l}\text { Martin Formation } \\
\text { Abrigo Formation }\end{array}$} & Late Devonian & $50-125$ & Sandy dolostone and minor shale \\
\hline & Middle to Late & & \\
\hline & Cambrian & $125-225$ & $\begin{array}{l}\text { Thin-bedded shale, limestone, dolo- } \\
\text { stone, sandstone, and siltstone }\end{array}$ \\
\hline Bolsa Quartzite & Middle Cambrian & $50-125$ & Quartzite, pebbly near base \\
\hline \multicolumn{2}{|c|}{ Aggregate pre-Naco Paleozoic strata } & $\sim 500$ & (Marine and marginal marine) \\
\hline
\end{tabular}

beneath the region (Heidrick and Titley, 1982). Ages of 80 and $40 \mathrm{Ma}$ are commonly cited as bracketing the Laramide orogeny, for those two dates are approximately coincident with changes in plate motions that may have controlled onset and termination of the Laramide event (Coney, 1971, 1976). Times of initiation and cessation of deformation along major Laramide structures in the Rocky Mountain region are somewhat more tightly bracketed by ages of approximately 75 and $45 \mathrm{Ma}$ (Cross, 1986). The time span of the Laramide orogenic episode in southern Arizona is inferred principally from the observed range in radiometric ages for associated igneous rocks, most of which were intruded or erupted from 75 to $50 \mathrm{Ma}$ (Damon and others, 1981). However, Laramide igneous assemblages in Arizona include both metaluminous suites, such as the typical Cretaceous to Paleocene porphyry copper stocks (Titley, 1981, 1982), and younger peraluminous suites, some of which were emplaced within a time interval long regarded as part of the hiatus between Laramide and mid-Tertiary magmatism (Keith, 1982).

Laramide volcanoplutonic assemblages in southern Arizona range from about mid-Campanian to mid-Eocene in age (Fig. 8). Characteristic metaluminous suites of calc-alkalic andesitic to rhyolitic volcanic rocks and subvolcanic granitic plutons all predate $55 \mathrm{Ma}$, within early Eocene time. In adjacent northeast Sonora, however, available radiometric ages $(n=10)$ for typical
Laramide igneous systems (Damon and others, 1983) are all early Eocene ( 52 to $58 \mathrm{Ma}$ ). The peraluminous two-mica granites of southern Arizona apparently range generally (Fig. 8) from early Eocene to mid-Eocene in age (55 to $45 \mathrm{Ma}$ ), although the $\mathrm{U}-\mathrm{Pb}$ age $(58 \mathrm{Ma})$ of the somewhat older Pan Tak Granite in the Coyote Mountains (Figs. 3B and C) lies near the PaleoceneEocene time boundary (Wright and Haxel, 1982). The peraluminous magmas were probably crustal melts formed late in the Laramide event as lower crustal sources were: (a) heated by gradual advective transfer of heat from mantle to crust by rising metaluminous magmas, (b) fluxed by volatiles derived from progressive dehydration of the underthrust slab as it warmed in the mantle, or (c) brought to liquidus temperature by radiogenic heat production within an overthickened crustal profile formed by thrusting (Reynolds and Keith, 1982; Haxel and others, 1984; Farmer and DePaolo, 1984). All these alternate modes of magma origin would perhaps have been at peak effectiveness when the shallow subducted slab in the mantle beneath the region was plated subhorizontally beneath the continental lithosphere (Coney, 1980b).

\section{Laramide rocks}

Laramide rock assemblages within the study area include a wide variety of mainly Maastrichtian to Paleocene intrusive 

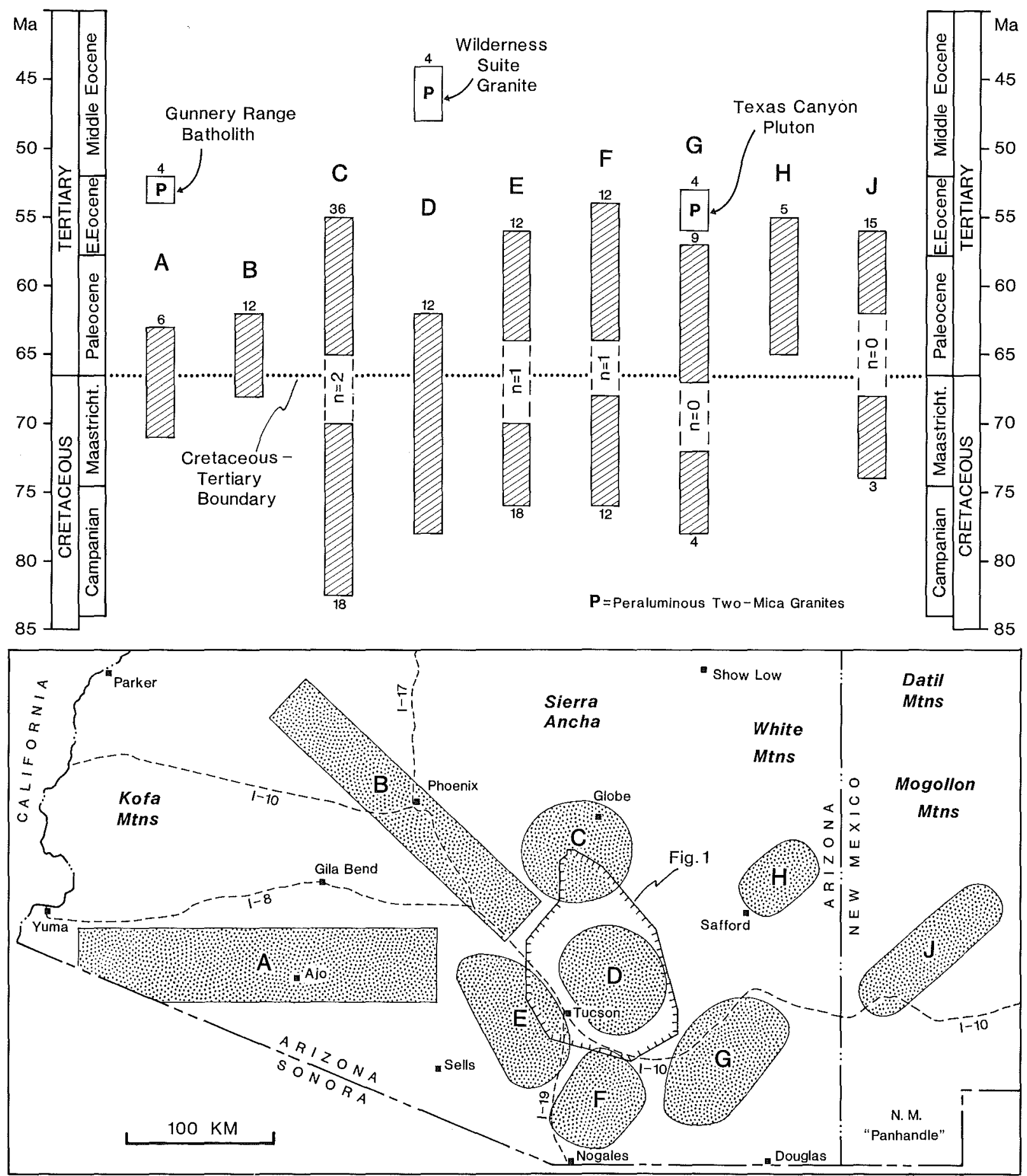

Figure 8. Space-time pattern of radiometric ages for Laramide igneous rocks (volcanic, hypabyssal, plutonic) in southern Arizona; bar columns keyed by letter to stippled areas on regional map below (numbers above or below shaded bars indicate the number of reported radiometric ages within the time span represented by the bar; numbers between bars indicate sparse radiometric ages falling within time gaps shown; total $\mathbf{n}=190$ ): A, southwestern Arizona including Ajo; B, Vulture, San Tan, Sacaton, Picacho mountains; C, Pinal, Mescal, Dripping Spring, Tortilla, Mineral mountains; D, Galiuro, Rincon, Santa Catalina, Tortolita mountains and Black Hills; E, Sierrita, Tucson, Roskruge, Silver Bell mountains; F, Santa Rita, Patagonia, Empire, Whetstone mountains and Canelo Hills; G, Dragoon, Little Dragoon, Dos Cabezas mountains and Tombstone Hills; H, Gila Mountains including Morenci; J, Lordsburg, Tyrone, Santa Rita, Hanover/Fierro, Pinos Altos and related stocks in southwestern New Mexico. Data from Reynolds and others (1986a) and Marvin and others (1988), supplemented by McDowell (1971) and Marvin and others (1978) for New Mexico. 
bodies, both plutonic and hypabyssal, and extrusive volcanic piles, as well as local accumulations of largely volcaniclastic synorogenic strata (Table 4). Middle Eocene peraluminous granite of the Wilderness granite suite (Fig. 8) also underlies a large part of the Catalina core complex (Fig. 9). In general, metaluminous plutonic and volcanic components of the Laramide igneous assemblage are broadly coeval, the sedimentary components are as young as or slightly younger than the metaluminous igneous suite, and the peraluminous intrusions appear to be younger than all other Laramide rocks.
Metaluminous intrusions and volcanic fields. Laramide granitic plutons older than the middle Eocene Wilderness granite suite are composed typically of granodiorite or tonalite rich in plagioclase but varying widely in color index (Table 5). Hypabyssal dikes and sills of granitic porphyry are widespread in many areas, especially outside the Catalina core complex, but are commonly too small to depict at the scale of Figure 1, on which only small stocks of similar rock appear. The hypabyssal porphyries (Table 4, A1) have been described variously as quartz monzonite, granodiorite, dacite, rhyodacite, and quartz latite porphyry.

TABLE 4. AGE AND DISTRIBUTION OF LARAMIDE ROCK ASSEMBLAGES*

(Exclusive of Wilderness granite suite of two-mica granite)

\begin{tabular}{|c|c|c|c|c|}
\hline A. Intrusive Units & $\begin{array}{l}\text { Estimated } \\
\text { Age (Ma) }\end{array}$ & $\begin{array}{l}\text { Area of } \\
\text { Exposure }\end{array}$ & $\begin{array}{l}\text { Approximate } \\
\text { Extent }\left(\mathrm{km}^{2}\right)\end{array}$ & References \\
\hline 1. Kgp, granitic porphyry dikes and sills & $60-70$ & $\begin{array}{l}\text { Tortilla Mtns. } \\
\text { Black Hills }\end{array}$ & $<5$ (net) & $\begin{array}{l}\text { Creasey, 1965, 1967; Cornwall and others, } \\
\text { 1971; Krieger, 1974b, c; Cornwall and } \\
\text { Krieger, 1975a, b; Banks and Krieger, } 1977\end{array}$ \\
\hline 2. Kdi, semitabular dioritic bodies & $\sim 65^{\dagger}$ & $\begin{array}{l}\text { Tortilla Mtns. } \\
\text { Black Hills }\end{array}$ & $\sim 15$ (net) & Willden, 1964; Krieger, 1968e, 1974b \\
\hline 3. Kgc, Copper Creek granodiorite stock & $65-70$ & Galiuro Mtns. & $\sim 20$ & Simons, 1964; Creasey and others, 1981 \\
\hline 4. Krp, Rice Peak granodiorite porphyry & $65-75^{5}$ & $\begin{array}{l}\text { Santa Catalina Mtns. } \\
\text { (northeast) }\end{array}$ & $\sim 20$ & $\begin{array}{l}\text { Creasey, 1967; Keith and others, 1980; } \\
\text { Janecke, } 1986\end{array}$ \\
\hline 5. Kgh, Chirreon Wash granodiorite & $\sim 70$ & Tortolita Mtns. & 120 & $\begin{array}{l}\text { Banks and others, 1978; Keith and others, } \\
1980\end{array}$ \\
\hline 6. $\mathrm{Kgl}$, Leatherwood quartz diorite & $\sim 70$ & $\begin{array}{l}\text { Santa Catalina Mtns. } \\
\text { (northern) }\end{array}$ & 20 & $\begin{array}{l}\text { Creasey and Theodore, 1975; Creasey and } \\
\text { others, 1977; Banks, 1980; Keith and } \\
\text { others, } 1980\end{array}$ \\
\hline 7. Kgr, Rattler granodiorite stock & $70-75$ & Dripping Spring Mtns. & $<5$ & Cornwall and others, 1971 \\
\hline 8. Kgt, Tortilla quartz diorite & $70-75$ & Tortilla Mtns. & $5-10$ & $\begin{array}{l}\text { Cornwall and others, 1971; Cornwall and } \\
\text { Krieger, 1975a, b }\end{array}$ \\
\hline 9. Kga, Amole granitic pluton & $\sim 75^{\star \star}$ & Tucson Mtns. & 25 & $\begin{array}{l}\text { Bikerman and Damon, 1966; Drewes, 1981; } \\
\text { Lipman and Sawyer, } 1985\end{array}$ \\
\hline B. Stratified Units & $\begin{array}{l}\text { Estimated } \\
\text { Age (Ma) }\end{array}$ & $\begin{array}{l}\text { Area of } \\
\text { Exposure }\end{array}$ & $\begin{array}{l}\text { Approximate } \\
\text { hickness (m) }\end{array}$ & References \\
\hline 1. Kaf, American Flag Formation & $\sim 65^{\ddagger}$ & $\begin{array}{l}\text { Santa Catalina Mtns. } \\
\text { (northeast) }\end{array}$ & 750 & Creasey, 1967; Janecke, 1986 \\
\hline 2. Kcs, Cascabel Formation & $65-75^{5 s}$ & Galiuro Mtns. & 1,000 & Goodlin and Mark, 1987 \\
\hline 3. Kcv, Cat Mountain Rhyolite & $\sim 70^{\star \star}$ & Tucson Mtns. & $250-500^{\star \star \star *}$ & $\begin{array}{l}\text { Bikerman and Damon, 1966; Drewes, 1981; } \\
\text { Lipman and Sawyer, } 1985\end{array}$ \\
\hline 4. Kgv, Glory Hole Volcanics & $\sim 70^{+t t}$ & Galiuro Mtns. & 500 & Simons, 1964; Creasey and others, 1981 \\
\hline 5. Kmv, Muleshoe Volcanics & $\sim 75^{\$ \S}$ & Galiuro Mtns. & 750 & Goodlin and Mark, 1987 \\
\hline 6. Kwv, Williamson Canyon Volcanics & $75-82.5$ & Gila River Canyon & 1,000 & Simons, 1964; Willden, 1964; Krieger, $1974 \mathrm{C}$ \\
\hline
\end{tabular}

*Age estimates based on radiometric ages cited by Reynolds and others (1986a) unless noted otherwise.

tReported age may be reset by younger granitic porphyry body nearby (A1).

$\$$ Inferred by presumed comagmatic relationship to nearby Leatherwood quartz diorite (A6) and by analogy with granodiorite porphyry near Mammoth (see text).

**Apparent ages evidently inverted if Amole pluton (A9) intrudes Cat Mountain Rhyolite (B3).

FInferred from presumed unconformable relationship with Rice Peak granodiorite porphyry (A4).

${ }^{\$ \S}$ Based on radiometric ages cited by Goodlin and Mark (1987).

***Recent work implies an intracaldera thickness of 3,000 to $4,000 \mathrm{~m}$ and a total caldera-fill thickness of $\sim 5,000 \mathrm{~m}$ including overlying postcollapse andesitic to rhyolitic lavas (Lipman, 1989; Lipman and Fridrich, 1990).

${ }_{t+t}$ Older than reported radiometric age ( $\left.62.5 \mathrm{Ma}\right)$ because intruded by Copper Creek granodiorite (A3). 


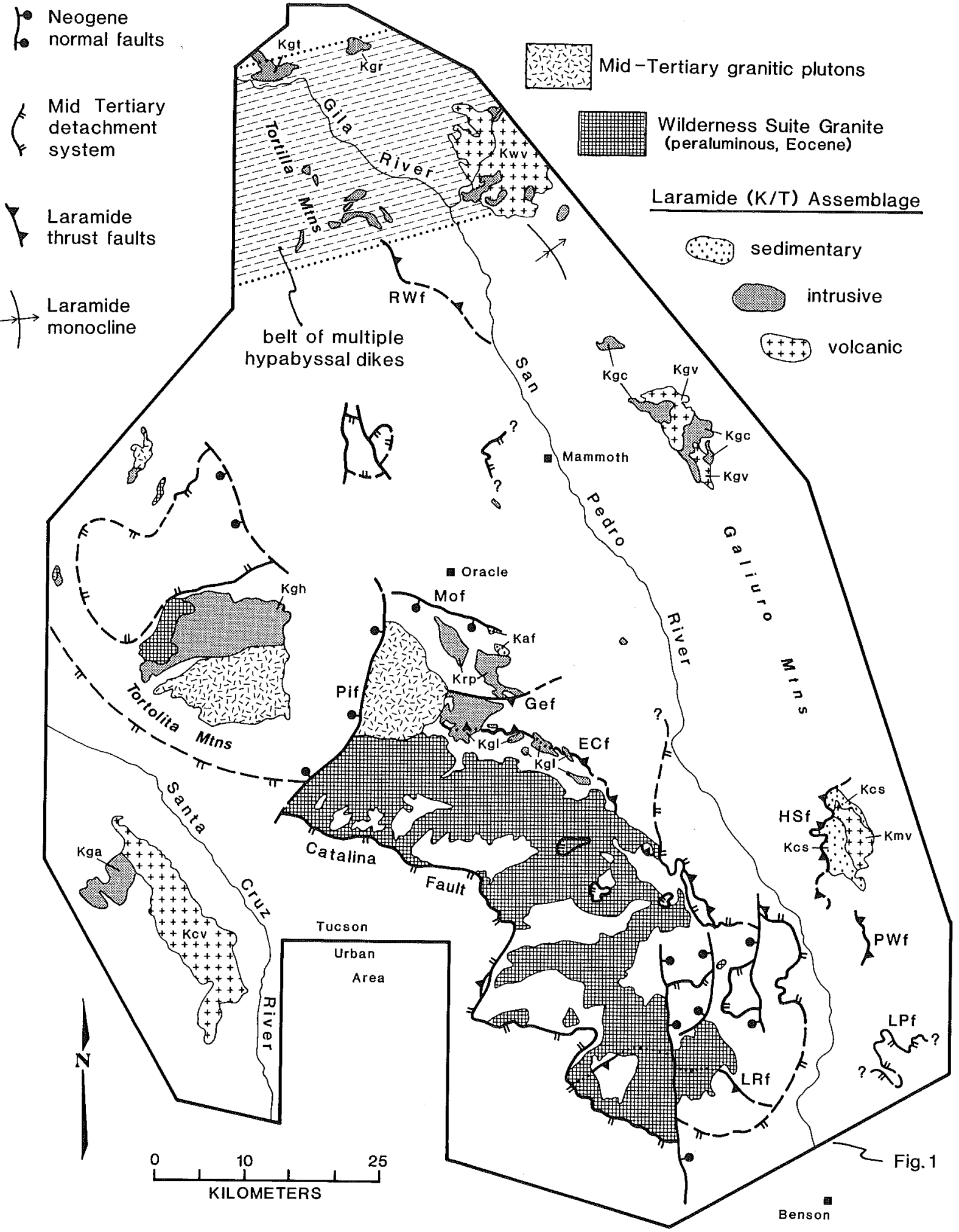

Figure 9. Exposed Laramide rocks and structures within the study area in relation to mid-Tertiary plutons and detachment system. Symbols for Laramide rock units from Table 4. Laramide thrust faults: ECf, Edgar Canyon; Gef, Geesaman; HSf, Hot Springs Canyon; LRf, Little Rincon; PWf, Palomas Wash system (multiple); RWf, Romero Wash. Other faults: Mof, Mogul (see text for discussion); LPf, Lime Peak; Pif, Pirate. Main exposures of Eocene peraluminous two-mica granite of the Wilderness granite suite occupy parts of Santa Catalina (on NW) and Rincon (on SE) mountains of Catalina core complex. 
Analogous semitabular bodies of more mafic intrusive rock (Table 4, A2) have been described variously as hornblende diorite, quartz diorite, microdiorite, and andesite porphyry. The entire spectrum of varied hypabyssal rock types is especially well displayed in the northern part of the study area (Fig. 9), where a complex swarm of near-vertical dikes trending ENE-WSW occupies a belt about $25 \mathrm{~km}$ wide flanking the Gila River (Schmidt, 1971).

The deepest seated of the metaluminous intrusive bodies lie along the northern side of the Catalina core complex as the Chirreon Wash granodiorite in the Tortolita Mountains and the Leatherwood quartz diorite in the Santa Catalina Mountains (Tables 4A and 5A). Both rock types occur as bulbous phacolithic intrusions partly concordant and partly discordant to structures in metamorphic country rock of Precambrian and Paleozoic age. Thermobarometric analyses of the depth of emplacement of the Leatherwood quartz diorite have reached conflicting conclusions. Whereas Anderson and others (1988) inferred emplacement at a depth in excess of $20 \mathrm{~km}$, Palais and Peacock (1987, 1990 ) inferred emplacement at 12 to $15 \mathrm{~km}$ or less, perhaps only $7.5 \mathrm{~km}$. The local occurrence of skarn-type orebodies in metamorphosed carbonate and calc-silicate rocks within Leatherwood contact aureoles is more compatible with the smaller depth esti- mate. Final interpretations ultimately may hinge upon whether the ubiquitous accessory epidote within the pluton is judged to be magmatic or deuteric in origin, and whether observed compositions of hornblende in the rock reflect the level of final pluton emplacement or some depth along the travel path of the magma as it rose toward the surface from its place of origin.

Exposed near the Leatherwood quartz diorite, and probably closely related in both age and petrologic affinity, are multiple sills of slightly older Rice Peak granodiorite porphyry (Table 4A) linked into an intricate reticulated network by crosscutting dikes (Keith and others, 1980; Janecke, 1986, 1987). The rock closely resembles typical Laramide porphyry (Creasey, 1965) that is associated spatially with the San Manuel and Kalamazoo porphyry copper orebodies located 15 to $20 \mathrm{~km}$ to the north between Oracle and Mammoth (Fig. 9). The granodiorite porphyry intrusive near Mammoth has yielded K-Ar ages of 65 to $70 \mathrm{Ma}$ (Reynolds and others, 1986a, \#1162 and \#1218). The lithologic correlation of the Rice Peak and San Manuel porphyry masses by Creasey (1967) provides key genetic linkage between Laramide plutonic assemblages inside and outside the Catalina core complex. The two porphyry masses are presumably subvolcanic intrusions, and thus serve also to link plutonic and volcanic facets of the Laramide igneous episode. The hypabyssal nature of Rice

TABLE 5. GENERAL COMPOSITION OF KEY LARAMIDE ROCK UNITS*

\begin{tabular}{|c|c|c|c|c|c|c|}
\hline $\begin{array}{l}\text { A. Intrusive Units } \\
\text { (Mineral percentages) }\end{array}$ & Quartz & Kspar & \multicolumn{2}{|c|}{ Plagioclase } & Biotite & Hornblende \\
\hline Copper Creek granodiorite (A3) & $20-25$ & $15-25$ & \multicolumn{2}{|c|}{$40-50$} & $5-15$ & $0-5$ \\
\hline Chirreon Wash granodiorite (A5) & $15-20$ & $10-15$ & \multicolumn{2}{|c|}{$40-45$} & $15-20$ & $5-15$ \\
\hline Leatherwood quartz diorite (A6) ${ }^{\dagger}$ & $20-25$ & $5-10$ & \multicolumn{2}{|c|}{$40-45$} & $10-20$ & $0-5$ \\
\hline Rattler granodiorite (A7) & $15-20$ & $10-15$ & \multicolumn{2}{|c|}{55.65} & 0.5 & $5-10$ \\
\hline Tortilla quartz diorite $(A 8)$ & $5-10$ & 0.5 & \multicolumn{2}{|c|}{$55-60$} & $0-5$ & $25-35$ \\
\hline $\begin{array}{l}\text { B. Stratified Units } \\
\text { (Volcanosedimentary rocks) }\end{array}$ & \multicolumn{3}{|c|}{ Dominant Lithology } & \multicolumn{3}{|c|}{ Minor Components } \\
\hline American Flag Formation (B1) & \multicolumn{3}{|c|}{$\begin{array}{l}\text { Pebbly gray volcaniclastic } \\
\text { sandstone, grading upward to } \\
\text { massive polymictic conglomer- } \\
\text { ate. }\end{array}$} & \multicolumn{3}{|c|}{$\begin{array}{l}\text { Basal sedimentary breccia, } \\
\text { local maroon red beds, } \\
\text { andesitic volcanic breccia. }\end{array}$} \\
\hline Cascabel Formation (B2) & \multicolumn{3}{|c|}{$\begin{array}{l}\text { Volcaniclastic to polymictic } \\
\text { conglomerate, pebbly sand- } \\
\text { stone, and finer-grained red- } \\
\text { beds. }\end{array}$} & \multicolumn{3}{|c|}{$\begin{array}{l}\text { Three welded rhyodacitic tuff } \\
\text { horizons, local flow of aphyric } \\
\text { andesitic lava. }\end{array}$} \\
\hline Glory Hole Volcanics (B4) & \multicolumn{3}{|c|}{$\begin{array}{l}\text { Gray to purple, andesitic to } \\
\text { dacitic volcanic breccia, tuff- } \\
\text { breccia, and welded tuff. }\end{array}$} & \multicolumn{3}{|c|}{$\begin{array}{l}\text { Andesitic lava and flow-brec- } \\
\text { cia. }\end{array}$} \\
\hline Muleshoe Volcanics (B5) & \multicolumn{3}{|c|}{$\begin{array}{l}\text { Gray to purple hornblende } \\
\text { andesitic breccia. }\end{array}$} & \multicolumn{3}{|c|}{$\begin{array}{l}\text { Andesitic lava and silicic weld- } \\
\text { ed tuff. }\end{array}$} \\
\hline $\begin{array}{l}\text { Williamson Canyon Volcanics } \\
\text { (B6) }\end{array}$ & \multicolumn{3}{|c|}{$\begin{array}{l}\text { Dark gray andesitic breccia } \\
\text { and lava. }\end{array}$} & \multicolumn{3}{|c|}{$\begin{array}{l}\text { Volcaniclastic conglomerate } \\
\text { and sandstone. }\end{array}$} \\
\hline
\end{tabular}

*Letier-number codes in parentheses refer to Table 4; references also in Table 4.

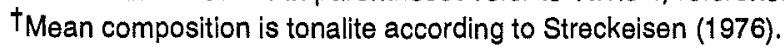


Peak granodiorite porphyry makes it unlikely that closely associated bodies of Leatherwood quartz diorite were emplaced at levels as deep as the midcrust.

In most places where Laramide intrusive and volcanic rocks are in direct contact, the intrusive bodies are clearly younger than the associated eruptive rocks. In the Tucson Mountains, however, work completed to date has not fully resolved the relationship between the Amole pluton and ignimbrite of the Cat Mountain Rhyolite. Although available radiometric ages imply that the ignimbrite is younger (Table 4), overall field relations suggest that the ignimbrite and associated tuff-matrix breccias represent the fill of a caldera along the margin of which the resurgent Amole pluton was emplaced (Lipman and Sawyer, 1985; Lipman, 1989; Lipman and Fridrich, 1990). Laramide volcanic rocks exposed elsewhere within the study area are dominantly andesitic lavas and breccias of locally erupted stratocones (Table 5B).

The original extent of Laramide volcanic cover within the study area was probably much broader than at present, for the stratigraphic thickness of Laramide volcanic units (Table 4B) is great in comparison to their preserved lateral extent (Fig. 9). Erosional stripping of Laramide volcanic products was evidently severe during Eocene time, and most notably so along the central NNW-SSE trend now occupied by the Catalina core complex and related uplands farther north (Fig. 9). The Laramide volcanic cover was probably never continuous across the whole study area, however, for clasts of pre-Laramide rocks are common in overlying Laramide sedimentary units. Along the trend of the present Galiuro Mountains, the Williamson Canyon, Glory Hole, and Muleshoe Volcanics (Fig. 9) may be local remnants of a once-continuous Laramide volcanic field, but past work is inadequate to test correlations of specific horizons within the three units. Available radiometric ages (Table 4B) permit the hypothesis that the three occurrences represent separate eruptive centers active at slightly different times.

Synorogenic sedimentary units. Exposures of synorogenic Laramide sedimentary sequences within the study area include the Cascabel Formation at Hot Springs Canyon in the southern Galiuro Mountains and the American Flag Formation along the northeastern flank of the Santa Catalina Mountains (Tables 4B and 5B). Both are composed largely of conglomeratic facies inferred to represent the deposits of alluvial fans constructed of sediment eroded from nearby Laramide highlands. However, the structural complexity of typical outcrops and the limited lateral extent of exposures makes interpretation of paleocurrent indicators and facies patterns uncertain with present information.

The Cascabel Formation (Goodlin and Mark, 1987) includes thick lower and upper members of polymictic cobble to boulder conglomerate interbedded with subordinate lithic sandstone, and a thinner middle member of massive to cross-bedded sandstone with lensoid pebble conglomerate interbeds. Two clast types are dominant: (a) volcanic rocks reworked from the underlying Muleshoe Volcanics, and (b) sandstone recycled from uplifted Bisbee Group. The strata include both clast-supported and matrix-supported conglomerates, which are interpreted as prod- ucts of stream-flood and debris-flow deposition, respectively. The observed local stratigraphic transition upward from conglomeratic to sandy and then again to conglomeratic beds apparently reflects initial retrogradation of the depositional system from proximal to medial or distal fan environments, followed by renewed progradation of the depositional system to produce proximal fan environments once again as the depositional basin filled.

At Hot Springs Canyon, the Cascabel Formation rests conformably and gradationally on the Muleshoe Volcanics, erupted approximately $75 \mathrm{Ma}$ near the Campanian-Maastrichtian time boundary (Table 4B). The contact is placed at the horizon where sedimentary clasts in conglomerate become more abundant than the volcanic clasts that are characteristic of the upper volcaniclastic horizons of the underlying unit. Tuffs in the highest exposed horizons of the Cascabel Formation have yielded radiometric ages that average 66 to $67 \mathrm{Ma}$, near the Cretaceous-Tertiary time boundary. As the exposed top of the formation is everywhere either faulted or an unconformity, deposition may well have continued into Paleocene time.

The extent of the Cascabel depositional basin is unknown. General lithologic similarity of the Cascabel Formation to parts of the Fort Crittenden Formation, exposed $100 \mathrm{~km}$ to the southwest (Hayes, 1987), need not imply continuity of original distribution despite probable overlap in age. In general, Laramide sedimentary basins in southeast Arizona and southwest New Mexico were bounded by abrupt margins marked by active reverse or thrust faulting, and were probably limited to a few tens of kilometers in individual extent.

The American Flag Formation, exposed only 30 to $40 \mathrm{~km}$ northwest of Hot Springs Canyon, is probably comparable in age to the Cascabel Formation and may represent part of the same depositional basin. Associated volcanic rocks exposed locally as part of the American Flag Formation closely resemble the Muleshoe Volcanics lithologically. Although Creasey (1967) concluded that the American Flag Formation is intruded by Rice Peak granodiorite porphyry, close examination of the contact relationship suggests that the American Flag Formation rests depositionally on Rice Peak granodiorite porphyry, and thus is most probably of latest Maastrichtian to Paleocene age. Bedding in the American Flag Formation parallels the contact, dikes and sills of porphyry are wholly lacking within American Flag exposures, and clasts of granodiorite porphyry indistinguishable lithologically from Rice Peak granodiorite porphyry are present sparingly within the American Flag Formation (Janecke, 1987). The most abundant clast types were derived, however, from the Oracle/Ruin granite suite of the Precambrian basement and from overlying Proterozoic and Paleozoic sedimentary cover including limestone, dolostone, and quartzite. Laramide volcaniclastic detritus is also abundant near the base of the American Flag Formation, which includes varied fluvial facies.

Peraluminous two-mica granite. Exposures of the leucocratic Wilderness granite suite occupy nearly half the exposed interior of the Catalina core complex (Figs. 1 and 9). The peraluminous Wilderness granitoids typically contain both muscovite 
and biotite, and most are garnet-bearing, but some garnet-free phases contain only biotite as mica. Associated dikes and irregular bodies of aplite, pegmatite, and alaskite are common and locally voluminous, both as internal phases of Wilderness plutons and as swarms of intrusions injected into varied wallrocks. Local terms for geographically separate but lithologically similar representatives of the peraluminous suite include Derrio Canyon granite in the Tortolita Mountains, type Wilderness granite and Lemmon Rock leucogranite in the Santa Catalina Mountains, Youtcy granite in Redington Pass between the Santa Catalina and Rincon mountains, Espiritu Canyon granite and Wrong Mountain granite in the Rincon Mountains, and Happy Valley granite in the Little (or eastern) Rincon Mountains, as well as the "gneiss of Windy Point" and much of the so-called quartz monzonite of Samaniego Ridge (Keith and others, 1980). Typical percentages of key mineral constituents are as follows: quartz, 30; plagioclase, 35; K-feldspar, 27.5; biotite, 5; muscovite, 2.5; garnet, $<1$. Samples of undeformed Wilderness granite not affected by mylonitic deformation have yielded concordant radiometric ages (muscovite $\mathrm{K}-\mathrm{Ar}, \mathrm{Rb}-\mathrm{Sr}$ reference isochron, monazite $\mathrm{U}-\mathrm{Th}-\mathrm{Pb}$ ) indicating middle Eocene emplacement within the interval 44 to $48 \mathrm{Ma}$, with overlap of analytical uncertainties ( $\mathrm{n}=$ 5) at $46 \mathrm{Ma}$ (Shakel, 1978; Reynolds and others, 1986a).

Recent reconnaissance $\mathrm{U}-\mathrm{Pb}$ geochronology (Gehrels and Smith, 1990, 1991) indicates, however, that various bodies of the peraluminous Wilderness granite suite may actually have been emplaced over a time interval of perhaps $40 \mathrm{~m}$.y. from earliest Paleocene $(-65 \mathrm{Ma})$ to mid-Tertiary $(\sim 25 \mathrm{Ma})$ time. The possible implications of this information for the geologic evolution of the Catalina core complex are not explored adequately in this Special Paper. The likelihood that the episode of peraluminous Wilderness magmatism was prolonged means that: (a) inferred ages of structures cut by different Wilderness masses may not be wholly reliable, (b) Tertiary thermal conditions within the Catalina core complex may have been influenced by repeated advective transfer of heat carried upward with rising anatectic magmas, and (c) extensional mid-Tertiary deformation may have been partly coeval with the emplacement of voluminous granitic plutons.

No volcanic equivalents of Wilderness plutonic rocks are known, and probably none exist. Abundant aplite and pegmatite bodies, both within Wilderness plutons and injected into adjacent wallrocks, suggest volatile-rich magma that consolidated entirely below the surface when confining pressure was released during its rise through the crust. Thermobarometric studies completed to date suggest final emplacement within a depth range of 8 to 12 km (Anderson and Rowley, 1981; Palais and Peacock, 1987, 1990; Anderson and others, 1988). Gravity data suggest further that the present vertical dimension of the main Wilderness pluton in the Santa Catalina and Rincon Mountains of the Catalina core complex is also 8 to $12 \mathrm{~km}$ (Holt and others, 1986). As the present crustal thickness is only about $30 \mathrm{~km}$ (Wallace and others, 1986), the Wilderness mass must form a significant fraction of the local crustal profile.

\section{Laramide structures}

Laramide deformation within the study area involved: (a) synmetamorphic ductile strain within rock masses that now form part of the interior of the Catalina core complex, and (b) brittle faulting that affected rocks of the cover and surrounding areas. The overall geometry of total Laramide strain has never been established well because later Tertiary erosion and deformation has destroyed or obscured much of the Laramide record. It has proved particularly difficult to establish the net transport direction along local Laramide thrusts, for which nearly all present interpretations are to some degree equivocal. In general, key Laramide faults cannot be traced individually for more than 10 to $12 \mathrm{~km}$ along strike before interruption by peraluminous middle Eocene intrusions, truncation by mid-Tertiary granitic bodies, disruption by the mid-Tertiary detachment fault system, or burial beneath post-Laramide sedimentary or volcanic cover (Fig. 9). Moreover, tilting of variable amount to the northeast (Fig. 3B) during mid-Tertiary extensional deformation has doubtless affected the original dip of most Laramide structures.

Ductile structures inside the core complex. In the northeastern Santa Catalina Mountains, subhorizontal foliation and east-vergent $\mathrm{E}-\mathrm{W}$ lineation in metasedimentary and metaigneous rocks of greenschist to amphibolite grade along the edge of the Catalina core complex reflect ductile synmetamorphic deformation of Laramide age (Bykerk-Kauffman and Janecke, 1987). Spatial and age relations of the tectonite fabric to other Laramide structural features are varied but informative:

(a) Development of the tectonite fabric largely predated intrusion of peraluminous middle Eocene two-mica granitic bodies of the Wilderness granite suite, although small dikes injected into metamorphic country rock are locally deformed (Bykerk-Kauffman, 1986). Southward increases in both metamorphic grade and fabric intensity (Bykerk-Kauffman, 1983, 1990), toward the main Wilderness pluton (Fig. 9), suggest that emplacement of the latter body served as a principal heat source and perhaps even as a source of stresses during synmetamorphic deformation, even though the pluton itself is undeformed and its margins clearly crosscut the ductile fabric (Bykerk-Kauffman and Janecke, 1987).

(b) Development of the tectonite fabric clearly postdated intrusion of diverse bodies of Rice Peak granodiorite porphyry and Leatherwood quartz diorite, both of which display mylonitic foliation and lineation that are geometrically and kinematically related to the Laramide tectonite fabrics of enclosing country rocks (Keith and others, 1980; Bykerk-Kauffman, 1986, 1990; Janecke, 1987). Foliation in Rice Peak granodiorite porphyry is locally pervasive. By contrast, the strain distribution in coarser-grained Laramide and Proterozoic granitic rocks affected by ductile Laramide deformation was markedly heterogeneous. For example, most mylonitic gneiss formed from Leatherwood quartz diorite during Laramide time occurs within widely spaced discrete shear zones only a few meters thick individually (Bykerk-Kauffman and Janecke, 1987). 
(c) Development of the tectonic fabric seemingly postdated movement along some Laramide thrusts, but other Laramide thrusts were apparently synmetamorphic. For example, movement on the Edgar Canyon fault (Fig. 9), placing Proterozoic strata above Paleozoic strata, evidently predated emplacement of the Leatherwood quartz diorite and presumably also predated development of the tectonite fabric (Bykerk-Kauffman, 1990). Alternatively, Leatherwood intrusion may have been late kinematic with respect to both the thrusting and development of the tectonite fabric (Bykerk-Kauffman, 1986). On the other hand, thrusting and wrench deformation along the nearby Geesaman fault (Fig. 9) were associated closely with ductile strain (Janecke, 1987).

A record of analogous Laramide deformation within the core complex is preserved by structural features exposed in the Little (or eastern) Rincon Mountains farther south (Smith and Gehrels, 1987). The Little Rincon thrust (Fig. 9), first mapped by Drewes (1974), places mylonitic augen gneiss derived from Oracle/Ruin protolith over metamorphosed Paleozoic strata and underlying Pinal Schist, with ductile thrust transport toward the northeast. Along strike to the northwest, the Little Rincon thrust and the penetrative tectonite fabric associated closely with it are truncated sharply along an intrusive contact with a local peraluminous pluton of the Wilderness granite suite. The same structures may emerge again in the southwestern Rincon Mountains beyond the exposures of Wilderness granite suite (Fig. 9). The Little Rincon thrust may also be a westward continuation of the northvergent Larmaide thrust system with east-west trend mapped by Cooper and Silver (1964) in the Little Dragoon Mountains (Fig. 3C) outside the study area (Dickinson, 1984).

In the Little Rincon Mountains southeast of Happy Valley (Fig. 2), and also near Barney Ranch northeast of Happy Valley, unfoliated masses of biotite granite in the eastern Rincon Mountains were described as "granodiorite of Happy Valley" by Drewes (1974) and as "Happy Valley quartz monzonite" by Keith and others (1980), but represent undeformed bodies of Wilderness granite suite that intrude foliated rocks produced by ductile Laramide deformation (Lingrey, 1982; Trever, 1983). In the Hidden Pasture drainage of the Little Rincon Mountains near Happy Valley (Fig. 2), the biotite granite grades into garnetbearing two-mica granite, which in turn gradually becomes mylonitic toward the southwest at the edge of the broad belt of mid-Tertiary ductile deformation flanking the Catalina core complex.

The Laramide assemblage of thrusts and intrusions with their associated tectonite fabrics terminates westward (Janecke, 1987) against the margin of the mid-Tertiary Catalina pluton (Fig. 9), and is overprinted locally by fault strands of the midTertiary detachment fault system (Bykerk-Kauffman, 1986). To the southeast, the assemblage is truncated along strike by the main detachment fault along the eastern side of the Rincon Mountains (Fig. 9). To the southwest, mid-Tertiary mylonitic fabrics along the flank of the Catalina core complex (Fig. 2) have essentially obliterated any evidence of earlier Laramide fabrics.
Brittle structures outside the core complex. Disconnected segments of Laramide thrust systems are exposed at intervals beneath Cenozoic cover along the trend of the San Pedro trough east of the Catalina core complex (Fig. 9), and numerous local folds are associated spatially with various thrust strands. Understanding the mutual relationships of these structures, as well as their relationship to Laramide structures within the core complex, awaits further topical studies. Several structures are notable, however, because of their bearing on the interpretation of the mid-Tertiary detachment system.

Near Kelsey Canyon, the Palomas Wash fault system (Fig. 9) of subparallel Laramide thrusts was mapped originally by Cooper and Silver (1964), and later by Drewes (1974). Trending north-south and dipping approximately $35^{\circ}$ to the east, these faults place Precambrian basement of the Johnny Lyon granodiorite suite and a sliver of Pinal Schist above varied Paleozoic and Mesozoic strata exposed in multiple thrust slices partly masked by basin fill. The sense of overturning of Bisbee Group beneath the main fault strand suggests thrust transport updip toward the west (Dickinson, 1986). West of the fault system, gently dipping strata of the Bisbee Group along Kelsey Canyon are wholly overturned ("upside down" to "doubly overturned") for a distance of approximately $2.5 \mathrm{~km}$ from exposed thrust traces. The overturning implies major tectonic transport along the thrust system, which may have had a subhorizontal attitude prior to mid-Tertiary tilting. Offset segments of the Palomas Wash thrust system are present as faults with similar structural stacking within cover rocks of the Catalina core complex both east and west of the Rincon Mountains (Lingrey, 1982; Krantz, 1983).

Farther north along the flank of the Galiuro Mountains, the Hot Springs Canyon fault is a Laramide thrust that places Bisbee Group above Cascabel Formation and dips approximately $25^{\circ}$ to the southwest (Dickinsona and others, 1987a). Inconclusive kinematic indicators suggest updip tectonic transport to the northeast, and severe disruption of Bisbee Group in the upper plate suggests the possible presence of a structurally higher thrust above the strand exposed (Goodlin and Mark, 1987). Areally restricted exposures of a thrust fault placing Pinal Schist above Bisbee Group less than $5 \mathrm{~km}$ to the south near Teran Wash (Grover, 1982) may be a cryptic record of such a higher structure.

In the southern Tortilla Mountains, the Romero Wash fault (Fig. 9) dips steeply eastward and repeats a homocline of Proterozoic Apache Group resting unconformably on basement rock of the Oracle/Ruin granite suite (Krieger, 1974a). Prior to midTertiary tilting, the Romero Wash fault had a subhorizontal attitude and placed basement above Apache Group in a geometric pattern reminiscent of the Walnut Canyon thrust exposed in the region northwest of the study area (Keith, 1986). Easterly transport of the upper plate relative to the lower plate is suggested by the sense of truncation of stratification in the Apache Group. Only the southern segment of the Romero Wash fault of Krieger (1974a) is interpreted here as a tilted Laramide thrust. The northern segment is interpreted instead as a low-angle normal fault dipping gently to the west and repeating the associated homocline 
of Apache Group as a result of mid-Tertiary extensional deformation. A tilted southern segment of the Romero Wash fault may be represented by the thrust placing Pinal Schist above Paleozoic strata near the mouth of Aravaipa Creek (Fig. 2), but the continuity of the two structures is masked by Cenozoic cover.

Perhaps the most problematical structure within the study area is the Mogul fault, exposed south of Oracle along the northern side of the Catalina core complex (Figs. 1 and 9). The Mogul fault strikes WNW-ESE, dips steeply (60 to $65^{\circ}$ ) SSW, and locally displays prominent fault striations oriented downdip. Extensive brecciation is common along both sides of the fault zone (Creasey, 1967). The stratigraphic separation across the fault suggests normal displacement of approximately $2,500 \mathrm{~m}$ to place sedimentary units of the Proterozoic Apache Group and various Paleozoic formations in the hanging wall against footwall basement composed mainly of Oracle/Ruin granite suite. Normal offset is seemingly compatible with principal activity during midTertiary or younger extensional tectonism, but the high topography of the hanging wall is atypical for known structures of that age elsewhere. The local presence of mylonitic fabric in both the hanging wall and the footwall within $25 \mathrm{~m}$ of the fault surface suggests that the Mogul fault might be a Laramide structural feature. If so, however, later reactivation is implied by minor offset of the Neogene Quiburis Formation along a subsidiary strand of the Mogul fault near the eastern end of its exposed trace (Creasey, 1967). The fault may have had a complex history of multiple movements at different times and further study is needed to understand its significance.

\section{TERTIARY TECTONOMAGMATIC RELATIONS}

Within the interior of the broad Cordilleran system between Canada and Mexico, Laramide orogenic deformation was succeeded by a mid-Tertiary interval of varied magmatism and taphrogenic deformation. From mid-Eocene to mid-Miocene time within the intermountain region between the Sierra Nevada and the Rocky Mountains, diachronous episodes of polymodal magmatism, including caldera or cauldron collapse, were accompanied or followed in many localities by rapid crustal extension marked by listric or rotational normal faulting, detachment systems, and structural denudation of metamorphic core complexes. Regional tectonic denudation is indicated by the prevalence of gently dipping faults along which younger rocks above are juxtaposed against older rocks below (Moores and others, 1968; Anderson, 1971; Armstrong, 1972, 1982). Crustal extension during tectonic denudation may have been associated with a pronounced thermal incursion related to coeval magmatism (G. H. Davis and Coney, 1979). Structural elision of at least 10 to $12 \mathrm{~km}$ of upper continental crust occurred where uplifted midcrustal levels are exposed immediately below detachment fault systems that bound tectonically denuded core complexes (Hamilton, 1982). Subsequent widespread block faulting within the Basin and Range province has been accompanied by the eruption of basaltic or bimodal (basalt-rhyolite) volcanic suites beginning in midMiocene time. Areas affected by the initial mid-Tertiary phase and by the subsequent basin-range phase of regional Cenozoic taphrogeny overlap (Fig. 3A) but are not coextensive (Coney, 1987; Hamilton, 1988a).

\section{Overview of inland Cordilleran magmatism}

Evolving patterns of Laramide and mid-Tertiary magmatism and tectonism across the wide extent of the Cordillera between Canada and Mexico display two key sequential trends (Fig. 10): (1) inland migration of waning magmatism from coastal to interior sites as orogenic deformation expanded to produce the Laramide province of the Rocky Mountain region, and (2) complex and incremental return migration of mid-Tertiary magmatism back toward the continental margin as taphrogenic deformation began within the intermountain region.

Geodynamic interpretations of the magmatic history depend upon the extent to which the magmatism reflected processes related to subduction. On the one hand, curvilinear belts of intermediate or polymodal volcanism can be viewed as the products of migratory arc magmatism induced by insertion of a subducted slab of oceanic lithosphere into the asthenosphere beneath the continental block. Although the presence of a subhorizontal slab of oceanic lithosphere subducted beneath the Cordillera during Paleogene time remains speculative (Fig. 6), thermokinematic calculations indicate that such a slab could have remained intact as far inland as Colorado during Laramide and mid-Tertiary subduction and magmatism (Severinghaus and Atwater, 1990). On the other hand, the irregular regional pattern of magmatic activity, and its distance from the continental margin, can be taken as evidence that arc magmatism was largely dormant within the intermountain region during mid-Tertiary time, and that processes not related directly to subduction controlled the distribution of most igneous rocks (Gans and others, 1989).

Based on the following lines of evidence, many of the inland volcanic fields are interpreted here as segments of a complex continental-margin magmatic arc system:

(1) Polymodal mid-Tertiary volcanic suites (composed of basalt, andesite, latite, dacite, rhyodacite, and rhyolite in varying proportions) are petrologically similar to modern igneous associations distributed widely around the modern circum-Pacific periphery where continental plates override oceanic plates along active subduction systems; the eruptive suites especially resemble the range of arc assemblages present today within the central Andean chain of South America and along the Sunda arc of Indonesia (Lipman and others, 1972; Snyder and others, 1976; Gans and others, 1989).

(2) Systematic transverse petrochemical trends observed regionally across the width of the Cordillera are analogous to those documented for modern arc systems (Lipman and others, 1971, 1972; Keith, 1978, 1982; Ewing, 1981; Clark and others, 1982; Cameron and others, 1983).

(3) The inland igneous belts interpreted here as arc assemblages form a space-time continuum of magmatic activity with linear igneous belts of undoubted arc affinity that were oriented 
subparallel to the continental margin and erupted close to the coastal fringe of the continental block; inland belts evolved from, developed into, or merged spatially with coastal belts.

(4) Tertiary magmatic activity in the Pacific Northwest and along the Southwest Border region was linked longitudinally with belts of arc magmatism lying parallel to the continental margin both to the north in British Columbia (Ewing, 1980) and to the south in the Sierra Madre Occidental of Mexico (Clark and others, 1982).

(5) The Cordilleran region is an integral segment of the circum-Pacific orogenic belt, along which evolving subduction zones and associated magmatic arcs that extend for $25,000 \mathrm{~km}$ along a great-circle path nearly girdling the globe have been in existence for about $200 \mathrm{Ma}$ (Dickinson and others, 1986).

The common association of the mid-Tertiary arc assemblages with taphrogenic deformation has fostered two specific challenges to this line of thought, but each can be discounted as follows:

(1) Wernicke and others (1987) have argued that crustal shortening associated with subduction along the continental margin is inconsistent with crustal extension inland, and hence that synextensional magmatism was not related to subduction. But overriding plates quite commonly undergo extension rather than compression while a regime of subduction is still in progress along the nearby plate margin (Hamilton, 1987, 1988b).

(2) Sonder and others (1987) have inferred that adiabatic release of pressure on underlying asthenosphere during crustal and lithospheric extension can produce mantle melts without need for slab subduction, and hence that subduction-related arc magmatism is an unnecessary hypothesis for the mid-Tertiary Cordillera. But the polymodal mid-Tertiary igneous suites are not universally associated with severe extensional tectonism (Lipman and others, 1970; Elston and others, 1976; Steven and others, 1984).

Although subduction is a conceptually simple model for much of the migratory Laramide and mid-Tertiary magmatism within the intermountain region, it is clear that the magmas erupted at the surface were polygenetic in origin (Johnson and Lipman, 1988; Gans and others, 1989). Partial melts produced by various interactions within the subjacent mantle were partially differentiated, and also contaminated by assimilation, as they rose toward the surface through subcrustal lithosphere and continental crust. Moreover, the mantle-derived magmas carried advective heat into the crust, and their rise also produced crustal and hybrid melts that form an integral part of the regional magmatic association (Johnson and Lipman, 1988; Ruiz and others, 1988).

Crustal extension may have played an important ancillary role by promoting magmatic hydrofracturing of crust extending under deviatoric stress (Lachenbruch and Sass, 1978). This process could promote passive intrusion of mafic mantle melts carrying the advective heat pulses that gave rise to the more silicic crustal and hybrid melts. Moreover, some alkalic rocks and bimodal assemblages of basaltic andesite and rhyolite erupted locally along the inland flanks of several segments of the mid-
Tertiary magmatic belt may reflect incipient arc-rear rifting akin geodynamically to backarc spreading (Barker, 1979; Eaton, 1979; Elston and Bornhorst, 1979; Steven and others, 1984; Christiansen and Yeats, 1990). The influence of changing crustal stresses on the style of arc magmatism may be shown best in west-central New Mexico; there, a sharp but conformable transition from intermediate andesitic and dacitic volcanics associated with waning Laramide compressive stresses, to a bimodal assemblage of basaltic andesite and silicic ignimbrites associated with incipient extensional tectonism, occurs at a stratigraphic horizon well dated near the Eocene-Oligocene time boundary (Cather and others, 1987; Cather, 1989, 1990).

Eruption of typical polymodal eruptive suites began with construction of widespread multiple stratocones composed of varied lavas and breccias of intermediate composition (andesite, latite, dacite), and concluded with emplacement of silicic ignimbrites (rhyolite, rhyodacite), both as cauldron fills within nested caldera complexes and as widespread outflow sheets (Lipman and others, 1970; Elston and others, 1976; Shafiqullah and others, 1978; Gans and others, 1989; Christiansen and Yeats, 1990). Where severe taphrogenic deformation was closely associated in time and space with volcanism, faulting reached peak intensity during or after the ignimbrite phase of activity, rather than preceding the onset of volcanism (Gans and others, 1989; Wark and others, 1990).

Coney $(1979,1980 \mathrm{~b})$ called special attention to the strong correlation between the flareup of ignimbritic volcanism during the coastward sweep of intermountain magmatism and the subsequent extensional deformation that was associated with tectonic denudation of metamorphic core complexes. Typically, voluminous ash flows whose travel was unimpeded by fault-block topography were spread as extensive ignimbrite sheets covering wide areas prior to the onset of taphrogenic deformation (Moores and others, 1968; Best, 1986; Elston, 1989). Indeed, the offset of ignimbrite stratigraphy is commonly the best guide to the geometry of extensional structures produced during mid-Tertiary taphrogeny. Along the Colorado River trough between Arizona and California, for example, a widespread and distinctive ignimbrite sheet of lower Miocene Peach Springs Tuff (18 to $19 \mathrm{Ma}$ ) clearly predated major extensional tilting and provides a convenient structural datum for delineating local extensional structures (Glazner and others, 1986; John, 1987; Miller and John, 1988; Nielson and others, 1990). Regional heterogeneity of tectonism is well illustrated by the observation that the same ignimbrite sheet is only gently tilted and unbroken by major faulting farther west in the Mojave Desert (Glazner, 1988).

\section{Regional magmatic patterns}

Prior to the onset of Laramide deformation, the principal belt of Cordilleran magmatism lay along the trend of Cretaceous coastal batholiths, which were emplaced 200 to $400 \mathrm{~km}$ inland from the Franciscan paleotrench and represent the roots of a Mesozoic magmatic arc built along the continental margin (Fig. 
10A). By the beginning of Maastrichtian time ( $75 \mathrm{Ma})$, magmatism had begun to migrate inland as its intensity waned. By the beginning of Tertiary time ( $\sim 65 \mathrm{Ma})$, a diffuse and discontinuous band of resultant magmatism lay 500 to $600 \mathrm{~km}$ inland from the paleotrench, and Laramide basement deformation had broken up the foreland region to distances as great as 1,250 to $1,500 \mathrm{~km}$ inland from the paleotrench (Fig. 10A). A magma-free corridor or magmatic null devoid of igneous activity developed within the intermountain region centered on the present Great Basin from mid-Paleocene $(\sim 62.5)$ to mid-Eocene $(\sim 45)$ time (Fig. 10B). Much of the Laramide foreland province was also amagmatic and a zone of intense foreland magmatism in Colorado may have been more closely related to fracturing of the continental plate than to the presence of a subducted slab in the mantle beneath (Christiansen and Yeats, 1991).

A Paleocene plutonic belt in western British Columbia marks the position of the Laramide arc trend to the north (Ewing, 1980), and the basal igneous complex of the Sierra Madre Occidental represents the continuation of the arc assemblage southward into Mexico (McDowell and Clabaugh, 1979). Widespread Laramide igneous rocks present along the Southwest Border region (Figs. 8 and 10A) reflect magmatism that was contiguous southward into the latter igneous complex, which lies unconformably beneath the mid-Tertiary ignimbrite plateau of the Sierra Madre Occidental (Damon and others, 1981).

Progressive shallowing (Fig. 6A) and eventual flattening (Fig. 6B) of the dip of a slab of oceanic lithosphere subducted into the mantle beneath the continental block caused the extinction of arc magmatism near the paleotrench, inland migration of waning magmatism, expansion of Laramide orogenic deformation far inland, and eventual exclusion of arc magmatism from much of the intermountain region (Lipman and others, 1971; Coney and Reynolds, 1977; Keith, 1978, 1982; Dickinson and Snyder, 1978; Lipman, 1980). A more gently inclined slab configuration pushed the locus of magmatism gradually inland (Chadwick, 1985) because full penetration of asthenosphere by subducted lithosphere is required to induce arc activity (Cross and Pilger, 1978), and widened the belt of orogenic deformation by broadening the zone of effective plate interaction (Dickinson, 1981). Interplate shear was presumably at its peak, to produce maximal basement deformation, and arc magmatism was largely suppressed, when the subducted slab reached a subhorizontal attitude beneath the continental lithosphere (Fig. 6B).

If the logic is valid, the shallowest plate descent and the
Figure 10. Principal belts and loci of migratory magmatism associated with Laramide orogeny and mid-Tertiary taphrogeny in the western United States. Palinspastic reconstructions include restoration of (a) 75 $\mathrm{km}$ (or 20 to 25 percent) extension (E-W) of intermountain region along 49th parallel (U.S.-Canada border) after Parrish and others (1988) for map A only; (b) $200 \mathrm{~km}$ (or 40 to 45 percent) extension (E-W) of northern Great Basin along 42nd parallel (north Nevada border) after Bogen and Schweickert (1985) for maps A-C, and half that amount for map D; (c) $150 \mathrm{~km}$ (or -75 percent) extension (E-W) of Death ValleyLake Mead region (near south tip of Nevada) after Wernicke and others (1982) for maps A-C, and half that amount for map D, although Wernicke and others (1988a) suggest somewhat greater net extension $(\sim 250$ $\mathrm{km}$ ); (d) $100 \mathrm{~km}$ (or $\sim 67$ percent) extension ( $60^{\circ} \mathrm{E}-\mathrm{S} 60^{\circ} \mathrm{W}$ ) of southern Basin and Range province (south of south tip of Nevada), including Colorado River extensional corridor (Howard and John, 1987), as nominal value for maps A-C, and half that amount for map D; (e) $200 \mathrm{~km}$ of Paleogene dextral slip on proto-San Andreas (pSA) fault after Dickinson (1983) for map A only; and (f) $325 \mathrm{~km}$ of Neogene dextral slip on San Andreas (SA) fault after Stanley (1987), and $110 \mathrm{~km}$ of Neogene dextral slip on subparallel San Gregorio-Hosgri fault closer to the present coastline after Dickinson (1983), for all maps (CA/BC line is pre-slip border between California and Baja California). Patterns depicted for the Pacific Northwest conform to serial tectonic rotations described by Wells and others (1984), Gromme and others (1986), Heller and others (1987), and Wells and Heller (1988); patterns depicted for the Great Basin honor constraints on rotation delimited by Frei and others (1984) and Frei (1986), but possible northward motion of the Sierra Nevada block during Tertiary time (Frei, 1986; Wells and Heller, 1988) is not compensated. Neogene tectonic rotations and local magmatism in the California coastal region are not shown. Maps modified after Snyder and others (1976), Stewart and others (1977), Cross and Pilger (1978), Dickinson and Snyder (1978), Dickinson (1979), McDowell and Clabaugh (1979), Lipman (1980, 1981), Damon and others (1981), Chadwick (1985), Bird (1984), Reynolds and others (1986b), R. L. Armstrong and P. Ward (personal communication, 1988), and Christiansen and Yeats (1991). A, Maastrichtian and Paleocene time (74 to $58 \mathrm{Ma}$ ): Zones of intense Laramide magmatism (shaded), interpreted here as segments of a magmatic arc migrating inland from the coastal batholith belt (axis marked), were quiescent by mid-Paleocene time except near the Canadian and Mexican borders; geodynamic significance of Laramide foreland magmatism in Colorado remains uncertain. B, Paleocene/Eocene time boundary to mid-Eocene time ( 58 to $44 \mathrm{Ma}$ ): Middle Eocene Absaroka (in Wyoming/Montana), Challis (in Idaho), Sanpoil (in Washington), and correlative Pacific Northwest volcanic fields are interpreted here as parts of a broad reinstituted magmatic arc that (1) was coeval with the main phase of extensional deformation associated with metamorphic core complexes (solid black) north of the Snake River Plain (Wust, 1986a; Parrish and others, 1988), but (2) postdated Laramide deformation in the northern part of the central Rocky Mountains (Dickinson and others, 1988), and (3) had begun prolonged seaward and southward migration (cf., Figs. 10C, D); seamount volcanics now exposed along the Pacific Northwest coast were erupted 48 to $64 \mathrm{Ma}$ (Duncan, 1982) and accreted by $\sim 50 \mathrm{Ma}$ (Heller and Ryberg, 1983); geodynamic relations of foreland magmatism (crosses) uncertain; magmatism in Southwest Border region quiescent after early Eocene time except for peraluminous intrusions of two-mica granite. C, mid-Eocene to mid-Oligocene time (44 to $30 \mathrm{Ma}$ ): Arc magmatism of Clarno (central Oregon) and Tuscarora (northeast Nevada) volcanic fields migrated westward and southward into ancestral (or Western) Cascades chain and eastern Great Basin (where key midTertiary metamorphic core complexes are shown in solid black); continuity of magmatic arc between Pacific Northwest and Southwest Border regions through Colorado is uncertain; schematic Farallon (Vancouver)/ Pacific plate boundary shown approaching trench along continental margin southwest of California. D, mid-Oligocene to mid-Miocene time (30 to $14 \mathrm{Ma}$ ): Simple pattern of arc magmatism in Pacific Northwest, with mid-Miocene backarc basaltic volcanism, passed along strike into complex magmatic pattern farther south; selected metamorphic core complexes in solid black include three in eastern Great Basin (see also Fig. 10C) and two in southern Arizona (Catalina and Pinaleno core complexes of Fig. 3C). 
A) 74-58 Ma

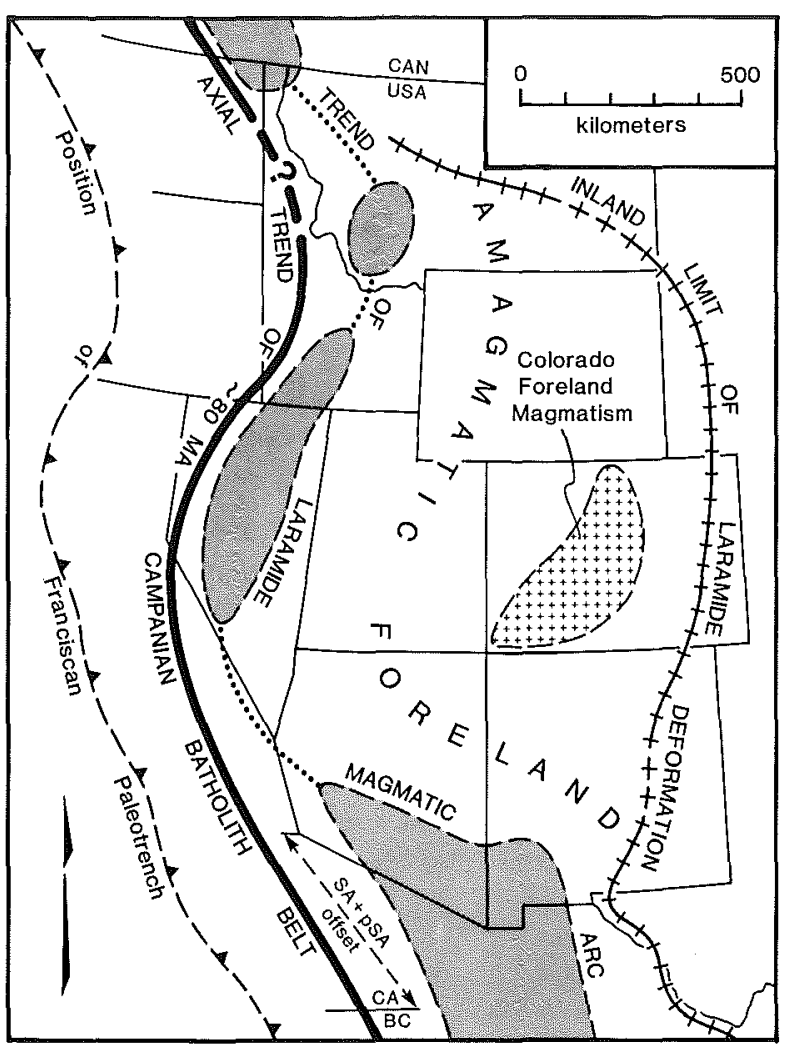

C) 44-30 Ma

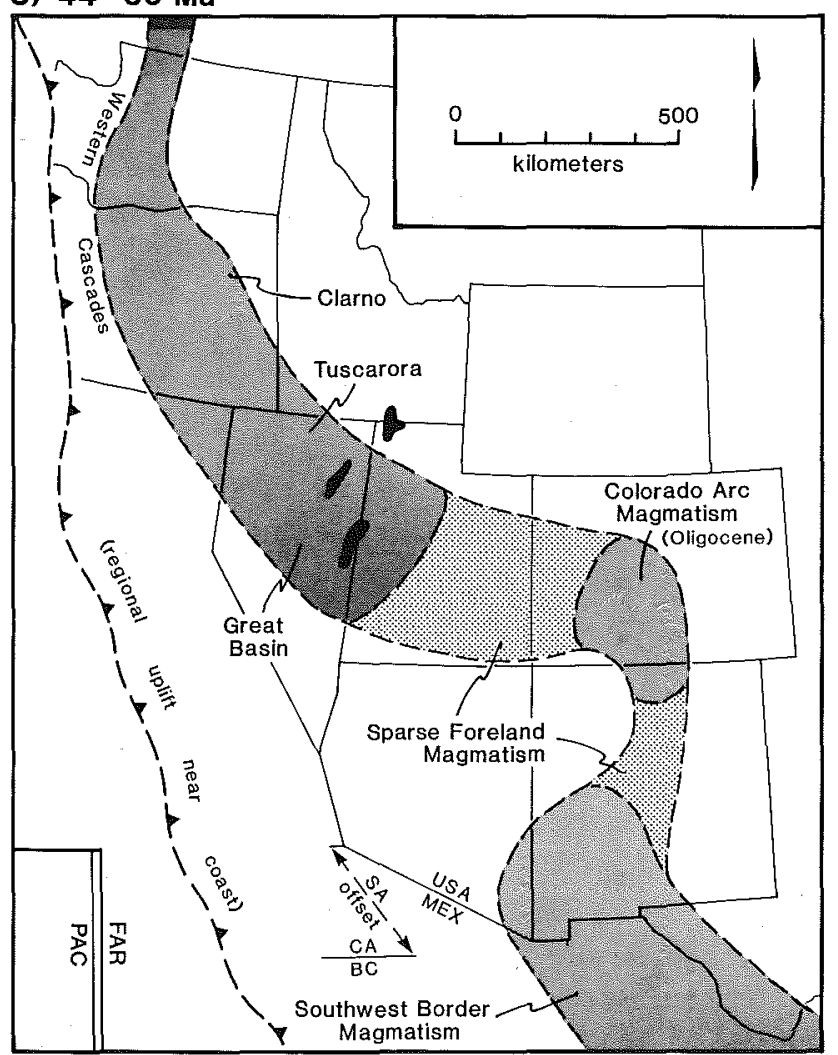

B) $58-44 \mathrm{Ma}$

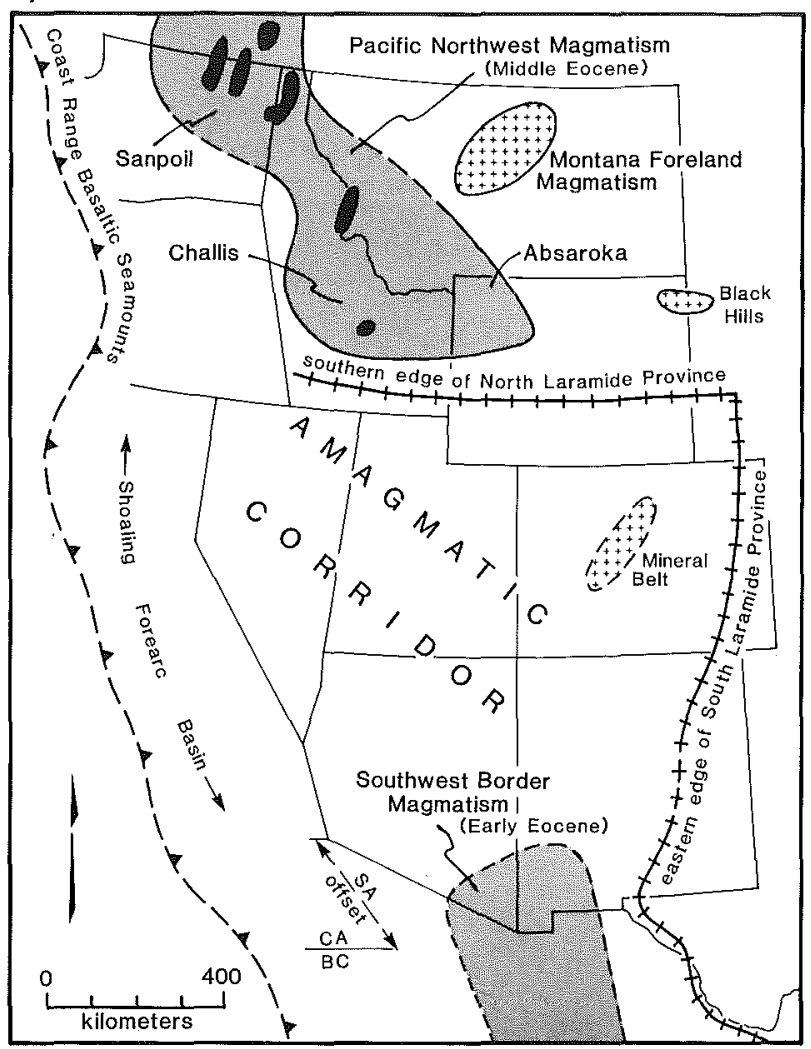

D) $30-14 \mathrm{Ma}$

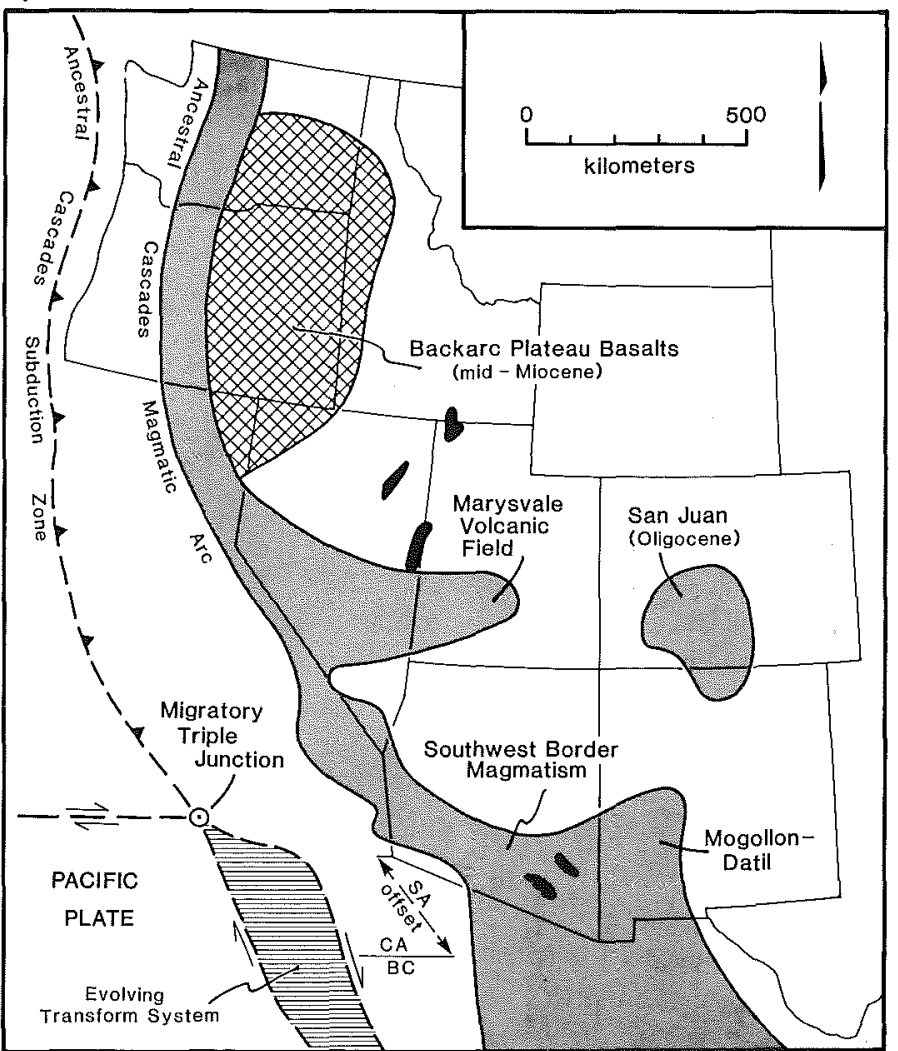


strongest orogenic deformation should correlate with the most pronounced null in arc magmatism as reflected by the extent of an amagmatic corridor within the intermountain region. Regionally, the magmatic null was slightly diachronous (Dickinson and Snyder, 1978), but the amagmatic corridor was largest about 55 to $60 \mathrm{Ma}$ near the Paleocene-Eocene time boundary, and Laramide deformation was also most intense in the central Rocky Mountain region between mid-Paleocene and mid-Eocene time (Dickinson, 1981; Dickinson and others, 1988). In the Southwest Border region, however, the magmatic null was most pronounced somewhat later (Keith, 1978; Damon and others, 1981), during mid-Eocene time ( 40 to $50 \mathrm{Ma}$ ). Moreover, voluminous twomica granite plutons in southern Arizona were emplaced during the null in local arc volcanism (Coney, 1980b; Keith, 1982; Spencer and Reynolds, 1989c).

Following the magmatic null in Paleogene time, piecemeal reinstitution of igneous activity across the intermountain region during mid-Tertiary time can be interpreted as a diachronous sweep of arc magmatism back toward the continental margin in response to incremental steepening (Fig. 6C) of the dip of the subducted slab (Cross and Pilger, 1978; Dickinson, 1979, 1981). Progressive steepening of a subducted slab is a feasible concept because its inclination at a given time is always a transient configuration reflecting net slab buoyancy, and not a set trajectory down a fixed slot in the mantle (Hamilton, 1987, 1988b).

The oldest post-Laramide magmatism interpreted here as a magmatic arc assemblage is represented by the Challis, Absaroka, Sanpoil, and related Eocene volcanic fields erupted within the interior of the Pacific Northwest about 500 to $600 \mathrm{~km}$ from the paleotrench (Fig. 10B). Peak activity (46 to $52 \mathrm{Ma}$ ) within middle Eocene time (Smedes and Prostka, 1972; Pearson and Obradovich, 1977; Leonard and Marvin, 1982; Marvin and others, 1982; McIntyre and others, 1982) coincided generally with the episode of extensional tectonism and associated tectonic rotations that produced the northern group of metamorphic core complexes (Coney, 1979, 1980b; G. A. Davis, 1980). Coeval Eocene arc volcanics farther north form a belt about $250 \mathrm{~km}$ wide extending parallel to the continental margin along the entire length of central British Columbia (Ewing, 1980). The origin of coeval alkalic igneous rocks of the Montana foreland was probably not related directly to subduction, but perhaps instead to distal fracturing of the continental plate (Christiansen and Yeats, 1991). Early to middle Eocene volcanic suites of the Pacific Northwest postdated Laramide orogenic deformation throughout the northern part of the extensive Laramide province (Fig. 10B), but Laramide deformation continued through Eocene time farther south (Dickinson and others, 1988).

By late Eocene and early Oligocene time (Fig. 10C), arc magmatism had migrated into the ancestral or western Cascades of the Pacific Northwest, and extended obliquely across the Great Basin of Nevada and western Utah at distances as much as 750 $\mathrm{km}$ from the paleotrench. The progressive outward shift in the position of the most intense eruptive activity through time (Figs. $10 \mathrm{~B}$ through D) was coupled with longitudinal linkage of mid-
Tertiary magmatism in the Great Basin with coeval magmatism of undoubted arc affinity in the Pacific Northwest. These relations jointly suggest that the mid-Tertiary magmatic belt of the Great Basin was related to the subduction of a slab whose inclination below the continental block gradually steepened through time (Noble, 1972). The Clarno Formation (Fig. 10C), a well-studied interior suite erupted 34 to $50 \mathrm{Ma}$ in central Oregon (Gromme and others, 1986), has been described with confidence as subduction-related magmatism (Rogers and Novitzky-Evans, 1977; Noblett, 1981), and was erupted along tectonic strike from the Tuscarora volcanic field of northern Nevada (Christiansen and Yeats, 1991).

The east-west orientation of successively younger belts of mid-Tertiary magmatism in the Great Basin can be interpreted as the record of a migratory warp or flexure in the subducted slab (P. W. Lipman in Stewart and others, 1977; Dickinson and Snyder, 1978; Lipman, 1980). This bend in the slab is inferred to have connected a steeply dipping segment of the slab in the Pacific Northwest with a more gently dipping segment in the Southwest Border region, and to have migrated southward through mid-Tertiary time to cause arc volcanism to sweep generally southward as well as westward across the Great Basin. The climax of caldera development in the southern Great Basin occupied parts of late Oligocene and early Miocene time (Best and others, 1989). The Oligocene volcanics of arc aspect erupted farthest from the mid-Tertiary subduction zone are those of the San Juan and nearby volcanic fields in Colorado and adjacent New Mexico, which then lay 1,000 to $1,250 \mathrm{~km}$ from the paleotrench (Figs. 10C and D).

During late Oligocene and early Miocene time (Fig. 10D), migratory polymodal magmatism swept progressively closer to the continental margin until the magmatic front stood uniformly at distances of 250 to $500 \mathrm{~km}$ from the paleotrench. Concurrently, the trench had begun its Neogene evolution into a transform system as the Mendocino triple junction migrated northward along the continental margin adjacent to the Southwest Border region (Dickinson and Snyder, 1979a). An irregular pattern of late Oligocene and early Miocene eruptive centers dispersed widely across the Southwest Border region connected the linear Cascades arc trend with the equally linear Sierra Madre Occidental of western Mexico. By mid-Miocene time, a belt of igneous activity about $100 \mathrm{~km}$ wide extended contiguously southward near the California-Nevada border, along the western side of the Great Basin, from the southern end of the ancestral Cascades arc as far as southern Nevada (Christiansen and Yeats, 1991). However, arc magmatism had by then been extinguished farther east in the Great Basin and throughout the Southwest Border region. As migration of triple junctions steadily lengthened the San Andreas transform, the southern end of the active arc retreated spasmodically from a mid-Miocene $(\sim 12 \mathrm{Ma})$ position in southern Nevada to its present position at the southern terminus of the Cascades chain in northern California (Snyder and others, 1976; Eaton, 1984; Christiansen and Yeats, 1991). This northward retreat of arc magmatism west of the intermoun- 
tain region reflected the gradual enlargement of a post-Oligocene gap, or interruption in the magmatic arc, as the growing zone of lateral plate motion along the San Andreas transform supplanted subduction along the continental margin (Lipman and others, 1971; Dickinson and Snyder, 1979b).

Mid-Miocene and younger volcanic assemblages of the intermountain region contrast petrologically with the polymodal mid-Tertiary suites related to subduction. Neogene assemblages of three related kinds reflect either extensional tectonism or hotspot volcanism: (a) flood or plateau basalt fields, (b) alkalic basalt centers together with their diverse less-mafic differentiates, and (c) bimodal associations of basalt and rhyolite (Christiansen and Lipman, 1972). Voluminous flood basalt fields that cover the interior plateaus of the Pacific Northwest (Fig. 10D) were erupted mainly in mid-Miocene time (14 to $17 \mathrm{Ma}$ ), although eruptions continued locally and at reduced rates throughout the remainder of Miocene time (Watkins and Baksi, 1974; Hooper, 1982, 1988; Hart and Carlson, 1985). The basaltic lavas and associated rhyolitic centers of the Snake River Plain range from mid-Miocene (12 to $15 \mathrm{Ma}$ ) in age at their southwest limit to modern at their northeast limit near Yellowstone National Park (Armstrong and others, 1975). Coeval but less-voluminous basaltic and bimodal Neogene suites are widely distributed throughout the Basin and Range province (Christiansen and Yeats, 1991). Especially notable is a cluster of mid-Miocene and younger (6 to $14 \mathrm{Ma}$ ) silicic calderas in southwesternmost Nevada (Byers and others, 1989).

\section{Southwest border region}

In southeast Arizona, southwest New Mexico, west Texas, and adjacent parts of Mexico (Fig. 11), Laramide and midTertiary magmatism of varied local character effectively formed a continuum of igneous activity except during middle Eocene time $(40$ to $50 \mathrm{Ma})$. This igneous province of the Southwest Border region can be viewed as the northern continuation of the igneous assemblages of the Sierra Madre Occidental, which extends southward for about $1,200 \mathrm{~km}$ parallel to the Pacific margin of Mexico (Clark and others, 1982). The case for evolutionary arc magmatism, continuous in time though migratory in space (Damon and others, 1981), can be made convincingly for northern Mexico, where igneous activity that spanned $60 \mathrm{~m}$.y. from latest Cretaceous to early Miocene time ( 80 to $20 \mathrm{Ma}$ ) swept first eastward and then westward across a belt at least $500 \mathrm{~km}$ wide (Clark and others, 1982).

In the Southwest Border region, however, spatial patterns of coeval polymodal magmatism are not strongly diachronous (Figs. 8 and 11). Although gradual migration of igneous activity toward the northwest from early Oligocene to early Miocene time seems evident (Fig. 11), volcanism was widespread across much of the region during late Oligocene time. Diffuse westward migration of mid-Tertiary volcanism across southern Arizona is shown by scatter plots for ages of volcanic rocks erupted from mid-Eocene to mid-Miocene time (Reynolds and others, 1986c; Spencer and
Reynolds, 1989c), but areas displaying volcanic activity were broadly overlapping during that interval. Moreover, some have argued for northward rather than westward migration of midTertiary volcanism through the same area, and have suggested correlation of local peaks of volcanic activity with passage of the migratory triple junction along the continental margin to the west (Glazner and Supplee, 1982). Discrimination between westward and northward migration of magmatism within the Southwest Border region is inherently ambiguous because mid-Tertiary igneous rocks are abundant only in the Basin and Range province. The trend of the mid-Tertiary magmatic belt is thus controlled by the northwesterly trend of the margin of the Colorado Plateau (Fig. 11).

The general northwest-southeast trend of the belt of midTertiary magmatism in the Southwest Border region lay subparallel to the Pacific continental margin (Figs. 10C and D). This orientation is nearly at right angles to the expected transit direction of migrating arc volcanism moving from sites within the continental interior to sites closer to the continental margin. For this reason, any record of migratory behavior should be reflected primarily by shifts in the timing of magmatism transversely (northeast to southwest) across the belt, rather than along its strike. A subtle effect of this kind would be difficult to constrain with radiometric data, but no clear trend seems evident (Fig. 11). However, because the magmatic belt of the Southwest Border region had a trend of about $N 60^{\circ} \mathrm{W}$, slightly oblique to the continental margin at about $\mathrm{N} 45^{\circ} \mathrm{W}$, the gradual northwesterly migration of igneous activity may be a faint but faithful signal of arc migration toward the southwest in the region lying southwest of the Colorado Plateau.

Tectonomagmatic transition. The spatial continuity of mid-Tertiary igneous suites of the Southwest Border region with the immense ignimbrite plateau of the Sierra Madre Occidental farther south implies common petrogenesis related to subduction. The latter province seems clearly to represent a magmatic arc constructed parallel to the continental margin (Cameron and others, 1980; Wark and others, 1990). In the Sierra Madre Occidental, eruption of mid-Tertiary ignimbrites spanned the interval from early Oligocene to early Miocene time (34 to $22 \mathrm{Ma}$ ), and was succeeded by the eruption of alkalic basalt beginning by 12 Ma, late in middle Miocene time (McDowell and Keizer, 1977; McDowell and Clabaugh, 1979; Damon and others, 1981). The marked contrast in the petrologic character of the older midTertiary and the younger Neogene volcanic rocks suggests a major intra-Miocene transition in tectonomagmatic setting, from subduction-related arc activity to nonarc extensional tectonism associated with establishment of a transform regime along the adjacent continental margin. Recent work in Chihuahua has documented the presence of a precursor basaltic andesite suite of late Oligocene age (24 to $29 \mathrm{Ma}$ ) erupted during incipient intra-arc extension (Cameron and others, 1989). In Baja California, which lay along the Pacific margin of mainland Mexico prior to Neogene rifting to open the Gulf of California, polymodal Miocene arc assemblages of dominantly andesitic composition (16 to 20 


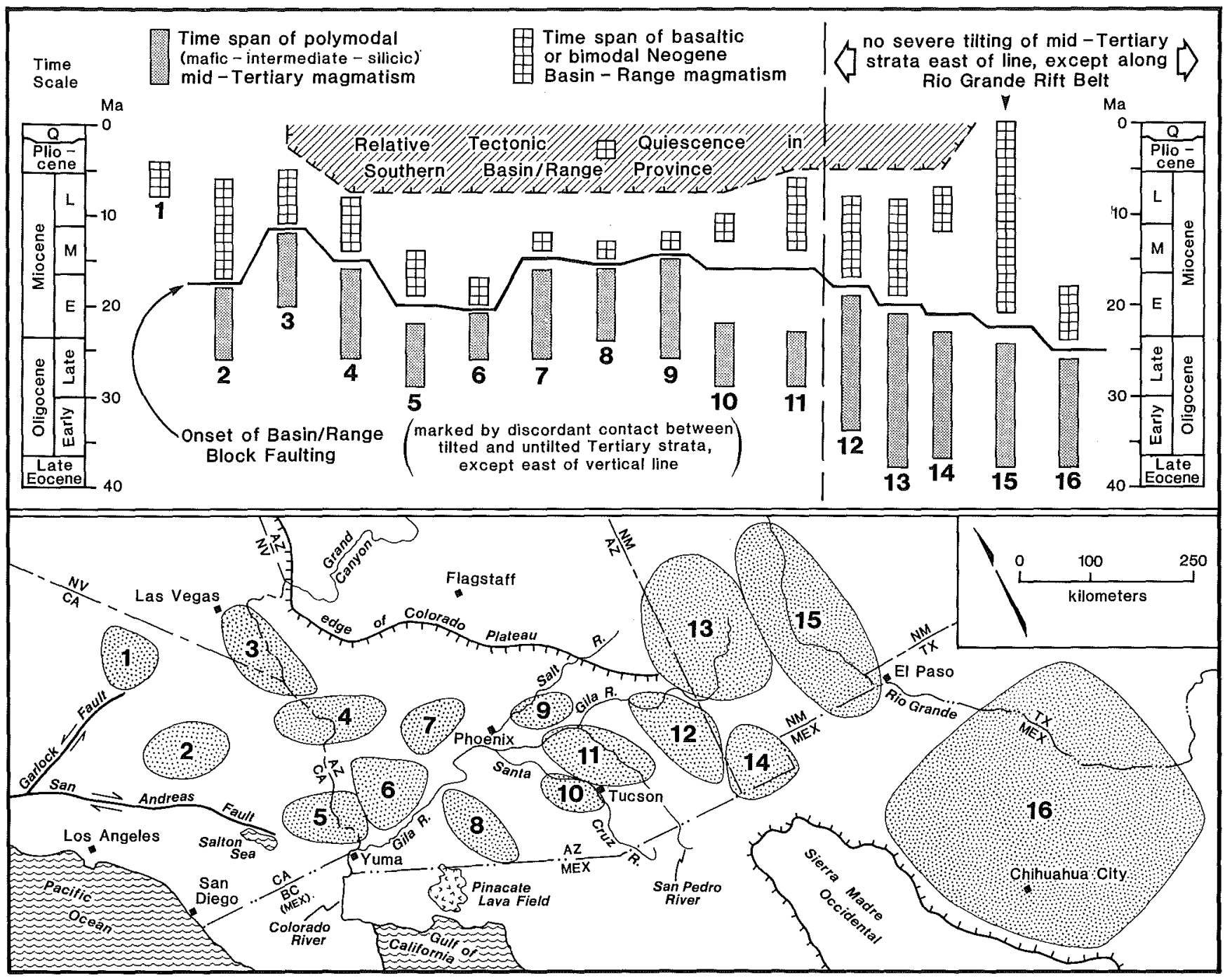

Figure 11. Time-space pattern of mid-Tertiary magmatism and deformation in the Southwest Border region; shaded bars denote diachronous pulse of mid-Tertiary magmatism accompanied or followed closely by fault-controlled stratal tilts throughout the region west of the vertical line; cross-hatched bars denote mid-Miocene and younger basin-range volcanism accompanied by block faulting without significant tilting of offset strata; subhorizontal but diachronous heavy line denotes transition between the two tectonomagmetic regimes (cf., Rehrig and others, 1980; Shafiqullah and others, 1980; Damon and others, 1984). Data from Reynolds and others (1986a) for Arizona supplemented by additional references for numbered subareas designated as follows: 1, Death Valley area (Fleck, 1970; Cemen and others, 1985); 2, Central Mojave Desert (Burke and others, 1982; Woodburne and others, 1982, 1990; Dokka, 1986, 1989; Dokka and others, 1988); 3, Eldorado, Black mountains (Anderson and others, 1972; Bohannon, 1984); 4, Whipple Mountains, Castaneda Hills, Date Creek Basin (G. A. Davis and others, 1980, 1982; Suneson and Lucchitta, 1979, 1983; Otton, 1982; Spencer, 1985; Nielson and Beratan, 1990; Spencer and others, 1989b); 5, Chocolate, Trigo mountains (Crowe, 1978; Crowe and others, 1979; Murray, 1982); 6, Kofa, Plomosa, Eagletail mountains (Sherrod and others, 1987); 7, Big Horn, Vulture, Hieroglyphic mountains; 8, Ajo region; 9, Superstition Mountains (Stuckless and Sheridan, 1971; Sheridan, 1978); 10, Silverbell, Roskruge, Tucson mountains; 11, Galiuro, Tortilla mountains and Catalina core complex; 12, Chiricahua, Peloncillo, Gila mountains (Marvin and others, 1978, 1988); 13, Mogollon-Datil Plateau (Elston and others, 1973, 1976; Ratte and others, 1984; Cather and others, 1987; Marvin and others, 1988; McIntosh, 1989; Cather and Chapin, 1989; Baldridge and others, 1989); 14, southwesternmost New Mexico (Deal and others, 1978); 15, southern Rio Grande rift (Chapin and Seager, 1975; Seager and Morgan, 1979; Baldridge and others, 1980; Chamberlin, 1983; Seager and others, 1984; Chapin, 1988, 1989); 16, Trans-Pecos Texas and Chihuahua basin-range region (McDowell, 1978; McDowell and Clabaugh, 1979; Henry and others, 1983, 1989; Henry and Price, 1984, 1986; Stevens and Stevens, 1985; Gunderson and others, 1986). 
Ma to the north and 12 to $20 \mathrm{Ma}$ to the south) are succeeded by basaltic suites whose oldest members are $14 \mathrm{Ma}$ in the north and $11 \mathrm{Ma}$ in the south (Gastil and others, 1979; Sawlan and Smith, 1984). A regional mid-Miocene tectonomagmatic transition is thus indicated for all of northern Mexico.

An early to middle Miocene tectonomagmatic transition is also well documented for the Southwest Border region (Fig. 11). Polymodal mid-Tertiary volcanic suites dominated by intermediate stratocones and clusters of ignimbrite calderas were succeeded diachronously by basaltic lavas. The latter were erupted in association with the construction of monogenetic cinder cones and accompanied in some occurrence by rhyolitic domes and tuffs of strongly bimodal assemblages. The change in the character of the magmatism coincided throughout the western part of the Southwest Border region with a structural transition from strongly tilted volcanic units, offset during or shortly after eruption by low-angle listric or rotational normal faults, to flat-lying or gently dipping lavas and tuffs offset locally by steep normal faults but otherwise undeformed.

The contact between tilted and untilted volcanic rocks varies in age on a subregional scale (Shafiqullah and others, 1980; Damon and others, 1984), but is an intra-Miocene feature within the interval 12 to $20 \mathrm{Ma}$ (Morrison, 1985) throughout southern Arizona and adjacent desert regions of southern California (Fig. 11). Farther east, where mid-Tertiary volcanic rocks are not strongly tilted except along the Rio Grande rift belt, an analogous tectonomagmatic transition from mid-Tertiary polymodal volcanism to younger basaltic or bimodal volcanism also coincided with the onset of pronounced block faulting (Fig. 11). To the south, the Rio Grande rift belt merges imperceptibly with the southeastern extension of the Basin and Range province (Elston and Bornhorst, 1979; Seager and Morgan, 1979; Henry and others, 1983). A tectonomagmatic transition there from tilted polymodal volcanic rocks to block faulting with associated basaltic or bimodal volcanism occupied the same intra-Miocene interval of 12 to $20 \mathrm{Ma}$ as farther west in southern Arizona (Lipman, 1981).

From place to place within the Southwest Border region (Fig. 11), the two phases of magmatism coexisted to some extent throughout the transitional interval (12 to $20 \mathrm{Ma}$ ). In southern Arizona and adjacent regions, strontium isotope ratios provide a clear signal of the date by which the mid-Miocene change in the character of magmatism and tectonism had been completed; they are uniformly higher than $\mathbf{0 . 7 0 5 5}$ in volcanic rocks erupted prior to 12 to $13 \mathrm{Ma}$ and uniformly lower than 0.7055 in volcanic rocks erupted later than 12 to $13 \mathrm{Ma}$ (Annis and Keith, 1986; Spencer and Reynolds, 1989c). Farther east, voluminous bimodal Jemez volcanism at the edge of the Rio Grande rift belt was also initiated about $13 \mathrm{Ma}$ in mid-Miocene time (Gardner and Goff, 1984; Gardner and others, 1986; Self and others, 1986). In detail, the onset of basaltic or bimodal magmatism within the Southwest Border region may have migrated sequentially from west to east as the slab window (Dickinson and Snyder, 1979b) associated with evolution of the San Andreas transform system along the coast expanded gradually through Miocene time (Seager and others, 1984).

In west Texas and adjacent parts of Chihuahua east of the Sierra Madre Occidental (Fig. 11), the comparable transition in magmatism accompanied by onset of block faulting occurred somewhat earlier (Stevens and Stevens, 1985), near the end of Oligocene time $(\sim 25 \mathrm{Ma})$. The timing of this transition along the inland fringe of the mid-Tertiary magmatic belt in the Southwest Border region was coincident with an analogous transition in the San Juan volcanic field, which occupied a similar paleotectonic position farther north (Figs. 10C and D). Polymodal San Juan volcanism, including construction of andesitic stratocones and collapse of ignimbrite calderas, occupied much of Oligocene time ( 26 to $36 \mathrm{Ma}$ ), and was succeeded after $\sim 25 \mathrm{Ma}$ by the eruption in Miocene time (14 to $24 \mathrm{Ma}$ ) of a bimodal suite of basalt and rhyolite along the flank of the adjacent San Luis Valley (Lipman and others, 1970; Lipman and Mehnert, 1975). Comparable but shorter phases of activity in the nearby but smaller Latir volcanic field near Taos occupied the intervals 25 to $28 \mathrm{Ma}$ and 11 to 16 $\mathrm{Ma}$ (Lipman and others, 1986). Along the north-south trend of the Rio Grande rift farther south in New Mexico, Tertiary tectonomagmatic history is still not fully understood but eruption of widespread ignimbrite sheets from major calderas had ceased by $24 \mathrm{Ma}$ and more restricted bimodal volcanism was dominant by $21 \mathrm{Ma}$, not long before initiation of modern segments of the present rift trough (Elston, 1989; Chapin, 1989).

Local volcanic fields. Southwest and northeast of the Catalina core complex, extensive mid-Tertiary volcanogenic sequences in the Tucson and Galiuro Mountains and associated uplands were erupted 24 to $29 \mathrm{Ma}$ in late Oligocene time (Fig. 12). Correlative strata in the volcanic lower member of the Cloudburst Formation (Fig. 2), exposed north and northwest of the Catalina core complex, record the same mid-Tertiary pulse of polymodal volcanism. In areas distant from volcanic centers, correlative sedimentary sequences contain intercalated lavas and tuffs at selected horizons. Lower Oligocene felsic tuffs that occur locally at or near the base of mid-Tertiary volcanosedimentary sequences reveal that incipient pre-mid-Oligocene volcanism preceded the main eruptive phase (Fig. 12).

The Galiuro Volcanics of the Galiuro Mountains, flanking the San Pedro trough on the east (Figs. 1 and 2), are the most extensively preserved erosional remnant of mid-Tertiary volcanic cover within the study area (Simons, 1964; Creasey and Krieger, 1978; Krieger, 1979; Creasey and others, 1981). The diverse volcanogenic strata of the Galiuro Volcanics include andesitic to latitic lavas that are commonly porphyritic, rhyodacitic to rhyolitic ignimbrites that are commonly welded, glassy rhyolitic domes and stubby flows, volcanic breccias of varied compositions and origins, and intercalated horizons of volcanic conglomerate. The aggregate stratigraphic thickness of the assemblage is approximately $1,750 \mathrm{~m}$, but most subunits are markedly lenticular and many are separated by erosional discordances. Full elucidation of the internal stratigraphy awaits further study. 


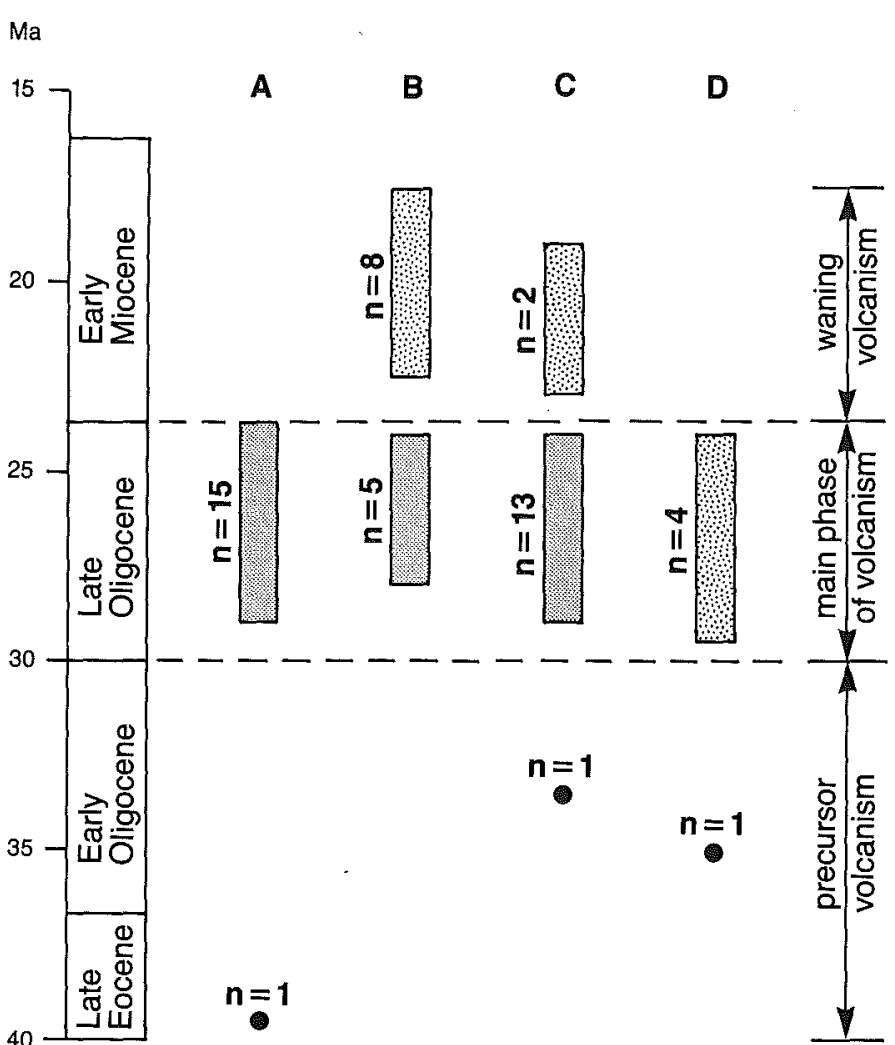

Figure 12. Age range (total $n=50$ ) of mid-Tertiary volcanic rocks within the study area. Dots denote individual stratigraphically isolated ignimbrite horizons, shaded bars denote dominantly volcanogenic successions of andesitic to rhyolitic volcanics, and stippled bars denote sedimentary sequences containing intercalated mafic lavas and silicic tuffs at selected horizons. Areas indicated (see Figs. 1 and 2): A, Tucson Mountains and Del Bac Hills southwest of Catalina core complex; B, Tortolita and Tortilla mountains and Black Hills northwest and north of Catalina core complex; C, Galiuro Mountains and adjacent part of San Pedro trough east of Catalina core complex; D, Cienega Gap south of Catalina core complex. Data from Dickinson and Shafiqullah (1989).

The eruptive centers for Galiuro volcanism are not well delineated, although dikes ranging from andesitic to rhyolitic in composition are abundant in many parts of the Galiuro Mountains. Lavas and associated breccias were probably derived from multiple local vents distributed across a landscape of both isolated and coalescing stratocones and associated domes. Sources for the interstratified ignimbrites are more uncertain. The external geometry and internal structure of typical ignimbrite units as exposed along Aravaipa Canyon (Krieger, 1979) are characteristic of outflow sheets. Evidence for rheomorphic flow of some welded tuffs exposed farther south, however, suggests accumulation either as thicker pyroclastic flows that may have ponded within collapse features formed near local vents, or as welded agglutinates produced by fountaining of silicic lavas above local vents. There is no clearcut evidence for a central caldera within the Galiuro Mountains, and some or all of the ignimbrite units may have been erupted from mid-Tertiary volcanic centers lo- cated elsewhere. If a local Galiuro caldera exists, it probably lies beneath the high central mass of the range as a tilted structure centered near the headwaters of Kielberg Canyon (Fig. 1) east of the structurally broadest segment of the adjacent San Pedro trough.

Following the prominent late Oligocene pulse of polymodal magmatism, waning volcanism continued intermittently through much of early Miocene time (Fig. 12). Olivine-bearing mafic lavas of earliest Miocene age ( 21 to $23 \mathrm{Ma}$ ) and lower Miocene silicic tuffs (18 to $22 \mathrm{Ma}$ ) are interbedded with conglomeratic sedimentary sequences that either rest depositionally upon upper Oligocene volcanic sequences or overlap the latter to rest directly on various pre-mid-Tertiary units (Dickinson and Shafiqullah, 1989). The local presence of volcanogenic horizons produced by this waning phase of mid-Tertiary volcanism affords the principal means of establishing the ages of different stratigraphic units within the local Miocene succession of syntectonic strata. Volcanic rocks of middle Miocene age are unknown within the study area and mid-Miocene stratigraphic relationships are consequently uncertain. Nearly flat-lying vitric tuff layers of upper Miocene age (5 to $7 \mathrm{Ma}$ ) occur in lacustrine basin-fill facies of the Quiburis Formation exposed within the San Pedro trough (Scarborough, 1975), but the maximum age of unexposed deeper horizons of undeformed post-mid-Tertiary basin fill remains undocumented.

Core complex plutons. Within the Catalina core complex, a composite granitic batholith of mid-Tertiary age (Creasey and others, 1977) occupies much of Samaniego Ridge along the western flank of the Santa Catalina Mountains, is exposed across the southern part of the nearby Tortolita Mountains, and presumably underlies intervening Oro Valley at depth beneath basin fill (Figs. 1 and 9). Two distinct granitic phases are present (Banks, 1980; Keith and others, 1980): (a) coarsely crystalline, granular to seriate or porphyritic, sphene-bearing and hornblende-bearing biotite granite termed "Catalina granite;" and (b) finer-grained, granular biotite granite termed "Tortolita granite." Both phases contain the following typical percentages of key mineral constituents: quartz, 30; K-feldspar, 35; plagioclase, 25; biotite, 10. Wherever the two phases are in contact, finer-grained Tortolita granite intrudes coarser-grained Catalina granite, commonly along contacts of intricate geometry marked by complex diking of the coarsergrained phase by the finer-grained phase. Limited geochronological data imply that the two granitic phases overlap somewhat in age from place to place (Reynolds and others, 1986a). The body mapped as Catalina granite in the Durham Hills (Fig. 1) is indistinguishable lithologically from the main Catalina granitic pluton, but is probably not contiguous with it. The small body mapped as Fortified Peak pluton of inferred mid-Tertiary age along the southern flank of the Black Mountains (Fig. 1) is more mafic, darker gray granitic rock with a probable mean composition of granodiorite.

Concordance of a single U-Pb age for Catalina granite with the age inferred from an $\mathrm{Rb}-\mathrm{Sr}$ isochron constructed from points for both Catalina and Tortolita granites suggests that the compos- 
ite mid-Tertiary granitic batholith was emplaced at approximately $26 \mathrm{Ma}$ in late Oligocene time (Reynolds and others, 1986a). The depth of emplacement was probably 4 to $9 \mathrm{~km}$ (Anderson and others, 1988). Multiple $\mathrm{K}-\mathrm{Ar}$ ages in the range 22 to $25 \mathrm{Ma}$ (Reynolds and others, 1986a) are probably cooling dates, but are permissive of plutonism continuing locally into Miocene time. The igneous fabrics of both the Catalina and Tortolita phases of the mid-Tertiary batholith were overprinted by mid-Tertiary mylonitic deformation along the flank of the Catalina core complex (Banks, 1980; Fig. 2). Unfoliated mid-Tertiary dikes that crosscut mylonitic fabric in the Tortolita, Santa Catalina, and Rincon mountains have yielded earliest Miocene $\mathrm{K}-\mathrm{Ar}$ ages of 21 to $24 \mathrm{Ma}$ (Reynolds and others, 1986a).

\section{Intermountain taphrogeny}

The comparative nature and origin of (a) mid-Tertiary extensional tectonism associated with tectonic denudation of metamorphic core complexes, and (b) younger extensional tectonism that produced the typical block faulting of the modern Basin and Range province are still unresolved questions. Field mapping has led to widespread recognition of two different families of structures: (1) subhorizontal mid-Tertiary detachment faults and other gently dipping normal faults now exposed typically within the interior of modern fault-block ranges, and (2) steeply to moderately dipping basin-range normal faults that offset the older structures and bound many of the modern fault-block ranges. There are two contrasting views of the significance of this structural dichotomy (Von Tish and others, 1985):

(1) On the one hand, there may be no fundamental distinction in structural style between mid-Tertiary faulting and later basin-range faulting (Hamilton, 1982; Wernicke and others, 1984; Bartley and others, 1988; Hodges and others, 1989). In this view of a continuum of Tertiary taphrogenic deformation in the intermountain region, observed differences between the two sets of structures are ascribed to differences in the present level of exposure of structures of different age (Hamilton, 1987). By implication, deeply eroded mid-Tertiary detachment systems and associated arrays of listric or rotational low-angle normal faults passed upward into steep fault systems of basin-range character near the surface.

(2) On the other hand, the two sets of structures may have arisen when the thermal structure of the crust and the geodynamic influences acting upon it were critically different (Shafiqullah and others, 1980; Morgan and others, 1986). This view of a fundamental intra-Miocene break or transition in tectonic style implies two distinct phases of intermountain taphrogeny during Tertiary time. By implication, mid-Tertiary structures formed during higher strain rates under a steeper geothermal gradient reflect a shallower transition from brittle to ductile behavior within the crust, and have no strict counterparts in the younger system of basin-range block faults (Seager, 1981; Eaton, 1982; Elston, 1989; Lucchitta, 1990).

The apparent dichotomy between the two hypotheses may be somewhat overstated. Taphrogenic structures formed at com- parable depths and temperatures under comparable strain rates are apt to be similar regardless of age and orientation (Hamilton, 1988a). Consequently, some analogies between selected midTertiary and post-mid-Miocene structures within the intermountain region are to be expected even if the two structural assemblages differ in their overall characteristics and tectonic setting.

The midcrustal rheological boundary between brittle upper crust and ductile lower crust is generally thought to migrate upward or downward in response to changing geothermal gradients as either extensional strain rates or the advective flux of magmatic heat vary (England and Jackson, 1987; DeVoogd and others, 1988). Of potential significance also for understanding the extent and nature of Tertiary intermountain taphrogeny is the recent suggestion by Bird (1988) that a special mechanism for regional delamination of lithosphere operated during Laramide deformation. His calculations suggest that shear interaction between the overriding continental plate and a subhorizontal subducted slab could have completely stripped subcrustal mantle lithosphere from beneath the continental crust throughout the intermountain region. In effect, the base of the continental lithosphere was eroded tectonically (Fig. 6B) against the subducting plate (Hamilton, 1988a). When asthenosphere later replaced the sinking subducted slab as intermountain taphrogeny began (Fig. 6D), asthenosphere may have been placed immediately subjacent to continental crust. If so, crustal geotherms may have risen, to allow ductile deformation at shallower levels, independent of either crustal stretching or advective magmatism.

Deformational phases. Considering the relationships depicted by Figure 11, a valid distinction can apparently be made between mid-Tertiary and post-mid-Miocene taphrogenic regimes. During the mid-Tertiary phase of taphrogeny, accompanied or immediately preceded by polymodal arc magmatism, severe stratal tilting during displacement of crustal segments along listric or rotational low-angle normal faults was achieved within brief intervals of geologic time. Certainly no more than 5 to 10 m.y. were required to produce dramatic disruption and tilting locally, and the time span involved may have been much less in some areas. During the succeeding post-mid-Miocene phase of taphrogeny, accompanied by basaltic or bimodal basalt-rhyolite volcanism, faulting that spanned at least $10 \mathrm{~m}$.y. in many local areas nevertheless failed to produce significant stratal tilting despite its longer duration.

The mid-Tertiary event has been called mid-Tertiary Basin and Range orogeny (Damon and Mauger, 1966), proto-Basin and Range deformation (Thompson and Zoback, 1979), preBasin and Range deformation (Zoback and others, 1981), midTertiary orogeny (Shafiqullah and others, 1978, 1980; Eberly and Stanley, 1978), mid-Tertiary extensional orogeny (Elston, 1976, 1984), and Galiuro orogeny (Keith and Wilt, 1985). In this Special Paper, however, the late Eocene to early Miocene episode of extensional tectonism and synextensional polymodal magmatism in the Great Basin and Southwest Border region is termed the mid-Tertiary phase of intermountain taphrogeny. This terminol- 
ogy accepts the argument that taphrogeny is a more appropriate designation for extensional deformation than orogeny (Sengor, 1987, 1990); reference to the Basin and Range province is avoided because analogous but older Eocene extensional tectonism associated with detachment systems in the Pacific Northwest affected regions lying outside the Basin and Range province.

The post-mid-Miocene event has been called the Basin and Range disturbance (Shafiqullah and others, 1978, 1980; Scarborough and Peirce, 1978) and the main Basin and Range deformation (Thompson and Zoback, 1979), or has been discussed informally in similar terms. In this Special Paper, the middle Miocene and younger episode of widespread extensional tectonism accompanied by basaltic and bimodal volcanism in the Great Basin and Southwest Border region is termed the basin-range phase of intermountain taphrogeny. In this usage, the compound phrase "basin-range" refers to the prevailing Neogene style of block faulting; the phrase "Basin and Range" is reserved to designate a well-defined physiographic province (Stewart, 1978; Christiansen and Yeats, 1991). Structures of the Basin and Range province include those inherited from the older mid-Tertiary phase of taphrogeny as well as those formed during the basinrange phase. Bird (1988) has recently used the term "Basin-andRange taphrogeny" to denote the combined or integrated effects of both mid-Tertiary and basin-range phases of intermountain taphrogeny as they were developed within the Basin and Range province.

Mid-Tertiary tectonism. The mid-Tertiary phase of intermountain taphrogeny was immediately preceded and in part accompanied by polymodal arc magmatism including voluminous ignimbrite eruptions, was marked by exceptionally high extensional strain rates locally, and was affected by regionally elevated geothermal gradients that were reflected by a comparatively shallow transition between brittle and ductile behavior within the crust (Shafiqullah and others, 1980; Lipman, 1981; Morgan and others, 1986). As mid-Tertiary taphrogeny ran its course while subduction was still underway along the continental margin (Gans and others, 1989), the causative geodynamic regime evidently developed in a tectonic setting that can be described at least in part as intra-arc, and perhaps also as arc-rear or backarc as extensional structures evolved (Coney, 1979, 1980b; Eaton, 1979, 1980, 1982; Elston, 1976, 1984; Thompson and Zoback, 1979; Zoback and others, 1981; Hamilton, 1982). The most characteristic features that record mid-Tertiary taphrogeny locally are subhorizontal detachment faults, all of which serve as denudational structures and many of which bound metamorphic core complexes. At depth, the detachment faults may continue into the mantle, merge with midcrustal shear zones, or pass into magmatic bodies that dilated the crust (Spencer and Reynolds, 1989c).

Five closely related geodynamic influences associated with steepening of slab descent beneath the intermountain region, and acting jointly in varied combination from place to place, are inferred here to have controlled mid-Tertiary taphrogeny (Fig. 6D):
(1) Reduction of interplate shear as shallow Laramide plate descent was succeeded by steep mid-Tertiary plate descent allowed significant reduction, actual release, or even reversal of intraplate compressive stresses acting laterally across the lithosphere of the intermountain region (Eaton, 1979; G. A. Davis, 1979, 1980; Coney, 1987; Coney and Harms, 1984; Bird, 1988). The resulting stress regime was analogous to that which produces marginal basins by arc splitting followed by backarc spreading (Zoback and others, 1981).

(2) Steepening of slab descent was logically accompanied, by analogy with the kinematic behavior of modern arc-trench systems, with subterranean rollback of the subducted slab (Coney, 1987; Hamilton, 1987, 1988a). This motion promoted retreat of the position of the trench along the continental margin with respect to the interior of the continental block, and allowed extensional deformation to occur within the intervening intermountain region (G. A. Davis, 1979; Rehrig and Reynolds, 1980).

(3) Overthickened crustal profiles, produced within the intermountain region by earlier episodes of Mesozoic and Laramide orogenic deformation, were isostatically compensated in a state of extensional deviatoric stress after prolonged orogenic thickening was arrested by changes in plate interaction (Sonder and others, 1987). As lateral compressive stresses gradually declined during steepening slab descent, an overthickened crustal welt tended to thin itself as oceanward retreat of the subduction zone provided room for it to spread laterally (Coney and Harms, 1984; Coney, 1987; Nourse, 1990).

(4) As arc magmatism swept back across the intermountain region during mid-Tertiary time, the advective heat transported into the intermountain lithosphere by voluminous magmas, generated in the subjacent mantle but injected upward into the overriding plate, achieved significant thermal softening or weakening of both the crustal and subcrustal lithosphere (Dickinson, 1979, 1981; Eaton, 1979; Reynolds and Rehrig, 1980; Coney, 1987; Hamilton, 1987, 1988a). This mid-Tertiary thermal pulse conditioned intermountain lithosphere and overthickened crust to fail readily under extensional stresses in response to reduced effective yield strength and crustal viscosity (Coney and Harms, 1984; Friedman and Armstrong, 1988; Gans and others, 1989).

(5) As steepening of the subducted slab continued, additional thermal and mechanical influences favorable for taphrogenic deformation may have been engendered by the subterranean counterflow of asthenosphere, which filled the wedge of space opening between surficial lithosphere of the intermountain region and the inclined slab in the mantle beneath (Dickinson, 1979; Lipman, 1981). This effect may have been pronounced if the subhorizontal Laramide subducted slab collapsed into the asthenosphere by incoherent breakup rather than by steepening itself as a coherent entity (Coney and Reynolds, 1977; Keith, 1978; Rehrig and Reynolds, 1980; Lipman, 1980; Henry and others, 1983; Elston, 1984; Chadwick, 1985; Rehrig, 1986).

Mid-Miocene transition. An intra-Miocene tectonic transition that marked the regional onset of typical basin-range block 
faulting was widespread though not exactly synchronous throughout the intermountain region, and was coupled rather closely in time with the prominent but enigmatic episode of midMiocene flood basalt magmatism (14 to $17 \mathrm{Ma}$ ) in the Pacific Northwest (G. A. Davis, 1980). In the Great Basin of Nevada and western Utah, a mid-Miocene transition from intra-arc extension during mid-Tertiary taphrogeny to backarc extension during basin-range taphrogeny is widely accepted (Thompson and Zoback, 1979; Zoback and others, 1981; Eaton, 1982). Noble (1972) inferred that the basin-range phase of intermountain taphrogeny commenced over much of the Great Basin at about the beginning of middle Miocene time (16 to $17 \mathrm{Ma})$ following an early Miocene (18 to $19 \mathrm{Ma}$ ) hiatus in local magmatism (McKee and others, 1970; McKee, 1971). Eruptions of basaltic or bimodal volcanic rocks had begun by middle Miocene time (13 to 14 $\mathrm{Ma}$ ) in many parts of the Great Basin (Gilbert and others, 1968; Robinson and others, 1968; Christiansen and McKee, 1978; Best and others, 1980; Duffield and McKee, 1986). Recent work (Bryant and others, 1989) along the Wasatch front near Salt Lake City confirms that rapid basin-range deformation began during mid-Miocene time (12 to $20 \mathrm{Ma}$ ). Basin-range taphrogeny also apparently began during middle Miocene time ( $\sim 16 \mathrm{Ma})$ in western Montana and eastern Idaho (Fields and others, 1985).

In the southern Basin and Range province of Arizona, recent workers all infer a middle Miocene (12 to $15 \mathrm{Ma}$ ) initiation of basin-range taphrogeny (Shafiqullah and others, 1978, 1980; Scarborough and Peirce, 1978; Eberly and Stanley, 1978; Nations and others, 1982, 1985; Damon and others, 1984; Keith and Wilt, 1985; Spencer and Reynolds, 1986, 1989c; Lucchitta, 1990). Along the flanks of the nearby Gulf of California, extensional tectonism of basin-range character also began in middle Miocene time (12 to $15 \mathrm{Ma}$ ), and controlled protogulf development prior to establishment of a throughgoing San Andreas transform system (Dokka and Merriam, 1982; Stock and Hodges, 1989; Henry, 1989). A similar tectonic transition with comparable timing occurred along the adjacent Colorado River extensional corridor (Nielson and Beratan, 1990), where strongly tilted strata of the Gene Canyon ( $\sim 20 \mathrm{Ma})$ and Copper Basin $(\sim 15$ Ma) Formations are succeeded by the gently tilted Osborne Wash Formation (10 to $12 \mathrm{Ma}$ ). Along the Rio Grande rift belt of central New Mexico, an analogous transition from widely distributed to concentrated crustal extension probably occurred slightly earlier, within the interval 15 to $20 \mathrm{Ma}$ (Cape and others, 1983), but the most pronounced block faulting that delineated the present rift trend also postdated $15 \mathrm{Ma}$ (Ingersoll and others, 1990). Bimodal volcanism was well established along the rift flank by $13 \mathrm{Ma}$ (Aldrich, 1986; Gardner and others, 1986).

Basin-range tectonism. The Neogene basin-range phase of intermountain taphrogeny was accompanied by subdued but widespread basaltic or bimodal basalt-rhyolite volcanism, and proceeded under generally reduced strain rates. The transition between brittle and ductile behavior within the crust was deeper than during the earlier mid-Tertiary phase of taphrogeny (Shafiqullah and others, 1980; Lipman, 1981; Morgan and others,
1986). Basin-range taphrogeny was initiated while much or all of the intermountain region lay in a backarc geotectonic setting, but continued as the San Andreas transform system gradually lengthened along the continental margin and progressively transferred most of the intermountain region to a "back-transform" setting (Stewart, 1978; Dickinson, 1979; Thompson and Zoback, 1979; Eaton, 1979, 1980, 1982, 1984; Hamilton, 1982; Glazner and Bartley, 1984; Coney, 1987).

Within the Southwest Border region, mid-Tertiary extension was oriented ENE-WSW (Fig. 3B), whereas later basin-range extension has been oriented more nearly east-west (Spencer and Reynolds, 1986, 1989c). Major basin-range block faulting was mainly late Miocene in age and generally predated 6 to $8 \mathrm{Ma}$ (Shafiqullah and others, 1980; Menges and McFadden, 1981; Suneson and Lucchitta, 1983; Morrison, 1985). Distributed extension across much of the breadth of the southern Basin and Range province may have been largely terminated when extension was concentrated along the axis of the transtensional Gulf of California near the end of Miocene time (Livaccari, 1979; Eaton, 1980; Coney, 1987). Subsequent Pliocene and Quaternary erosional modification of Miocene fault-block morphology has resulted in extensive pedimentation and basin filling (Lustig, 1969; Morrison, 1985).

Varied geodynamic controls have been suggested for basinrange taphrogeny (Stewart, 1978), but the concept of partial coupling of oblique shear between the Pacific and American plates along the San Andreas transform margin is the most attractive (Atwater, 1970; Coney, 1987; Hamilton, 1987). In this view, the mid-Miocene transition in the tectonic style of intermountain taphrogeny and the initiation of basin-range structure within the interior of the continental block reflected a critical stage in the tectonic evolution of the nearby continental margin. When Pacific-American transform plate boundaries (San Andreas and Queen Charlotte faults) reached sufficient net length, and the residual Cascades arc between the two transform systems reached a suitably diminished length, enough interplate lateral shear was applied to induce intraplate torsion within the entire intermountain region (Christiansen and McKee, 1978; Lipman, 1980). This rationale for mid-Miocene onset of basin-range taphrogeny is the only idea suggested to date that allows for nearly synchronous initiation of basin-range faulting throughout the intermountain region. The process began at a time when the Great Basin part of the Basin and Range province still lay behind an active magmatic arc, but the Southwest Border region of the southern Basin and Range province was already adjacent to an evolving transform system instead (Cross and Pilger, 1978).

Other geodynamic processes related to the evolution of the transform margin may have enhanced proclivity for extensional failure of the crust within the intermountain region, but in general do not provide satisfactory explanations for the nearly synchronous regional timing of basin-range deformation. Such corollary influences include: (a) the upwelling of asthenosphere through an expanding slab window adjacent to the transform system (Dickinson and Snyder, 1979b), (b) the kinematic requirement for 
lateral expansion of part of the continental block (Ingersoll, 1982) to compensate for the geometry of an unstable triple junction migrating along the continental margin (Dickinson and Snyder, 1979a), and (c) locally generated structural effects of the migratory edge of the subducted slab bounding the slab window (Glazner and Bartley, 1984).

Along the western margin of the Great Basin, basin-range faulting that began in mid-Miocene time (12 to $18 \mathrm{Ma}$ ) incorporated a strong component of stratal tilting well into late Miocene time (Gilbert and Reynolds, 1973; Proffett, 1977). Farther south, in the Death Valley region of California and adjacent southern Nevada, extensional detachment systems and associated lowangle normal faults have continued to develop into post-midMiocene time (Hamilton, 1987; Hodges and others, 1989). In both regions, however, extensional strain has decreased since 10 to $12 \mathrm{Ma}$ (Proffett, 1977; Wernicke and others, 1988a, b).

The occurrence of young structural features, in western Nevada and the Death Valley region, reminiscent of mid-Tertiary tectonism elsewhere may reflect maintenance of high crustalstrain rates along the inland flank of the San Andreas transform system. Along the western side of the Great Basin just east of the Sierra Nevada block, a prominent belt of dextral strike-slip faulting and associated pull-apart basins along the Walker Lane belt (Stewart, 1988) represents an anomalous subregional component of Neogene basin-range tectonism (Burchfiel and Stewart, 1966; Stewart and others, 1968; Stewart, 1983; Ekren and Byers, 1984; Hardyman, 1984; Cemen and others, 1985). Local superextension of crust within the Walker Lane belt may have influenced the structural geometry of associated extensional fault systems. Close interplay between detachment surfaces and strike-slip faults is especially notable in the Death Valley region (Hodges and others, 1989). Extensional strain rates that are high from any cause may promote midcrustal ductility by raising crustal geotherms (Spencer and Reynolds, 1986, 1989c; England and Jackson, 1987). In the Lemitar Range within the Rio Grande rift belt of concentrated Neogene extensional strain, pronounced stratal tilting also persisted into late Miocene time (Chamberlin, 1983).

\section{CORE COMPLEX GEOMETRY}

General aspects of Cordilleran metamorphic core complexes displaying mylonitic fabrics have been reviewed elsewhere (Coney, 1979, 1980b, 1987; Armstrong, 1982; Lister and Davis, 1989). Their most diagnostic structural feature is a gently dipping dislocation surface, described by some in the past as a décollement but now most commonly termed a detachment fault, which marks a pronounced contrast in structural style and grade of metamorphism between core rocks below and cover rocks above (Reynolds, 1985; Reynolds and others, 1988; Spencer and Reynolds, 1989b). Gently dipping subsidiary normal faults cut cover rocks without penetrating the detachment surface (G. H. Davis, 1980; G. A. Davis and Lister, 1988). In Arizona and nearby regions, net cumulative displacements along detachment faults are variously estimated in the general range 25 to $65 \mathrm{~km}$ (Reynolds and Spencer, 1985; Wernicke, 1985; Hamilton, 1987;
Howard and John, 1987; G. A. Davis, 1988; G. A. Davis and Lister, 1988; Spencer and Reynolds, 1989b, 1989c; Glazner and others, 1989; Walker and others, 1990). Multiple detachment surfaces are present in some cases (John, 1987; Spencer and Reynolds, 1990, 1991), and ductile deeper portions of the complex shear zones may have widened downward to produce broad belts of strain within the midcrust (G. H. Davis, 1983; Lister and Davis, 1989).

\section{Characteristic structural features}

Core complexes in southern Arizona (Figs. 3B and C) were denuded of complexly faulted cover during the mid-Tertiary phase of intermountain taphrogeny (Rehrig and Reynolds, 1980). The most widespread core lithology is mylonitic augen gneiss derived from granitic protoliths (G. H. Davis, 1980). Table 6 is a summary of characteristic structural relationships described by previous workers for core complexes in southern Arizona and nearby areas. All apply to the example of the Catalina core complex.

Current interpretations ascribe the development of the mylonitic fabric (Table 6A and B) in core rocks structurally beneath the detachment faults to ductile strain within extensional shear zones active at midcrustal levels. Subsequent brittle deformation, recorded by cataclasis and retrograde alteration that disrupts and overprints the mylonitic fabric (Table 6C), is attributed to continued shear as tectonic denudation brought the mylonitic rocks to shallower levels. The detachment faults (Table 6D) are discrete crustal ruptures along which cover rocks lacking a penetrative mylonitic fabric are placed into juxtaposition with underlying core rocks. These faults are viewed as the upward brittle extensions of shear zones that accommodated distributed ductile strain at depth. The broadly domical uplifts (Table 6E) that exposed detachment faults and structurally underlying mylonitic rocks to surficial erosion stem from processes still not fully understood. Tilting and faulting of cover rocks (Table 6F through $\mathrm{H}$ ) reflect marked extensional attenuation of the tapered wedge of crust lying structurally above the master detachment surface (Lucchitta and others, 1981).

Where the Catalina detachment fault structurally overlies mylonitic gneiss, thick chloritic breccia capped by a prominent outcropping ledge of cataclasite or microbreccia has typically developed just beneath the detachment surface (DiTullio, 1983). Farther northeast, in positions that were updip during detachment faulting, chloritic alteration is common for a few meters below the detachment surface even where no mylonitic fabric is present. Cover rocks are everywhere shattered by irregular, closely spaced fractures for several meters or tens of meters above the detachment fault. A few millimeters or centimeters of reddish fault gouge typically marks the detachment surface itself.

Thermal conditions required for mylonitic deformation of granitic rocks can be inferred broadly from experimental strain data showing that transition from brittle microcracking to ductile dislocation gliding occurs at 300 to $400^{\circ} \mathrm{C}$ in quartz and at 550 to $650^{\circ} \mathrm{C}$ in feldspar (Tullis and Yund, 1977). Mylonitic fabrics 


\section{TABLE 6. CHARACTERISTIC STRUCTURAL FEATURES OF METAMORPHIC CORE COMPLEXES} IN THE SOUTHERN CORDILLERAN REGION

A. Deformed core rocks display fluxion structure defined by gently dipping mylonitic fabric (ribbon quartz, granulated feldspar, bent and shredded mica, residual feldspar augen) composed of shear bands (C-surfaces) transecting flattening foliation (S-surfaces), and marked by prominent stretching lineation of strikingly consistent orientation and shallow plunge.

B. Mylonitic fabric in core rocks intensifies structurally upward toward core-bounding detachment fault system (documented only for complexes where post-detachment erosional dissection has been sufficient to expose appropriate structural levels).

C. Mylonitic fabric in footwall of detachment system is overprinted structurally by cataclasis and development of retrograde chloritic breccia cut by multiple fault strands for variable distances ranging as much as 100 to $250 \mathrm{~m}$ below exposed detachment surfaces (mylonitic foliation locally rotated by crosscutting structures).

D. Detachment fault is marked by resistant layer $(<1 \mathrm{~m})$ of flinty cataclasite or microbreccia with a structurally polished and slickensided upper surface in contact with sheared clay gouge, and displays undulatory antiformal and synformal corrugations or megamullions (amplitude 250 to $2,500 \mathrm{~m}$ and wavelength 10 to $25 \mathrm{~km}$ ) that are oriented parallel to footwall mylonitic lineation.

E. Configuration of detachment surface bounding tectonically denuded core rocks and attitudes of mylonitic foliation within core rocks jointly define a broad domal arch (structural relief 2.5 to $5 \mathrm{~km}$ and lateral dimension 25 to $50 \mathrm{~km}$ ) with a trend roughly transverse to more local antiforms and synforms defined by foliation attitudes and to detachment corrugations parallel to mylonitic lineation.

F. Tilted cover rocks in upper plate of detachment system are cut and structurally attenuated by multiple normal faults of variable dip that abut downward against or merge downward with the master detachment surface bounding variably brecciated mylonitic core rocks that form the lower plate of the detachment system.

G. Backtilted cover strata striking at right angles to the trend of mylonitic lineation, and dipping opposite to transport direction inferred from S-C relationships in mylonitic core rocks, reflect shingling of multiple tilt-blocks above the master detachment surface in kinematic coordination with mylonitic fabric in structurally underlying core rocks.

H. Syntectonic sedimentary cover strata deposited while detachment faulting and backtilting were underway display fanning dips from growth faulting, and contain megabreccia bodies derived by mass movement from evolving fault scarps and rising tilt-blocks.
Banks, 1980; G. A. Davis and others, 1980, 1986; G. H. Davis, 1980; Keith and others, 1980; Naruk, 1987a, b; Naruk and Bykerk-Kauffman, 1990; Rehrig and Reynolds, 1980; Reynolds, 1985; Reynolds and Rehrig, 1980; Shackelford, 1980, 1989.

G. H. Davis, 1983; Glazner and others, 1988; Miller and others, 1983; Naruk, 1987a, b; Rehrig and Reynolds, 1980; Reynolds, 1985; Reynolds and Rehrig, 1980; Spencer and Reynolds, 1986, 1989c; Walker and others, 1990.

Coney, 1980b; G. A. Davis and others, 1980, 1986; G. A. Davis and Lister, 1988; G. H. Davis, 1980; Frost, 1981; Glazner and others, 1988; Mathis, 1982; Rehrig and Reynolds, 1980; Reynolds and Rehrig, 1980; Shackelford, 1989; Spencer and Reynolds, 1989b; Walker and others, 1990.

Coney, 1979; G. A. Davis and others, 1980, 1986; G. A. Davis and Lister, 1988; G. H. Davis, 1983; Frost, 1981; John, 1982, 1987; Rehrig and Reynolds, 1980; Reynolds, 1985; Reynolds and Rehrig, 1980; Reynolds and Spencer, 1985; Spencer, 1984, 1985; Spencer and Reynolds, 1989b, 1991.

Coney, 1979, 1987; G. A. Davis and others, 1980; G. H. Davis, 1980, 1983; Howard and others, 1982b; Naruk, 1987a, b; Rehrig and Reynolds, 1980; Spencer, 1984; Spencer and Reynolds, 1986, 1989c; Wernicke, 1985.

Coney, 1979, 1980b, 1987; G. A. Davis and others, 1980; G. A. Davis and Lister, 1988; Frost, 1981; Glazner and others, 1988; Hamilton, 1987; McClelland, 1982; Rehrig and Reynolds, 1980; Reynolds, 1985; Shackelford, 1980; Spencer and Reynolds, 1989c.

Anderson, 1971; Armstrong, 1972; G. A. Davis and others, 1980 , 1986; G. H. Davis, 1980, 1983, 1987; Howard and others, 1982a; Lucchitta, 1990; Malavieille, 1987; Miller and others, 1983; Rehrig and Reynolds, 1980; Reynolds, 1985; Reynolds and Rehrig, 1980; Shackelford, 1980, 1989; Spencer, 1984, 1985; Spencer and Reynolds, 1986, 1989b, c.

G. A. Davis and others, 1980; Frost, 1981; Grier, 1983; Grover, 1984; Howard and John, 1987; Miller and others, 1983; Miller and John, 1988; Moores, 1968; Reynolds and Rehrig, 1980; Reynolds and Spencer, 1985; Spencer and Reynolds, 1986, $1989 b, c$. 
recording ductile strain of quartz and brittle strain of feldspar could thus be produced at approximately 450 to $500^{\circ} \mathrm{C}$. Studies of fluid inclusions and the distributions of selected elements between coexisting mineral phases confirm that mylonitic fabrics in the Catalina core complex and other core complexes of Arizona and nearby California formed at roughly $500^{\circ} \mathrm{C}$ (Kerrich and Rehrig, 1987; Kerrich, 1988; Anderson, 1988; Anderson and others, 1988; G. A. Davis, 1988; G. A. Davis and Lister, 1988). Analogous studies imply distinctly lower temperatures, near $300^{\circ} \mathrm{C}$ or less, for retrograde cataclasis that formed derivative chloritic breccias (Spencer and Welty, 1986; Kerrich and Rehrig, 1987; Kerrich, 1988).

Restorations of disrupted stratigraphic sequences in cover strata and reconstructions of paleothickness for tilted crustal blocks above detachment faults suggest that exposed mylonitic rocks of core complexes in the southern Cordillera were derived from initial depths of 10 to $12 \mathrm{~km}$ (Armstrong, 1972; Hamilton, 1982, 1987; Howard and others, 1982a; Gans and Miller, 1983; G. A. Davis and others, 1986; Howard and John, 1987; G. A. Davis and Lister, 1988; Gans and others, 1988; John and Mukasa, 1990). Recent geobarometry for mylonitic gneisses of upper greenschist to lower amphibolite metamorphic grade exposed along the southwest flank of the Catalina core complex indicates that mylonitic deformation occurred at a comparable depth (Anderson, 1988; Anderson and others, 1988).

Temperature and depth estimates for the site of mylonitic deformation in core complexes imply a slightly elevated crustal geothermal gradient of 40 to $50^{\circ} \mathrm{C} / \mathrm{km}$ (Hurlow and others, 1991). This value may reflect any one or a combination of related influences: (a) regional advection of heat during widespread arc magmatism that commonly preceded tectonic denudation; (b) local heat impulses derived from intracrustal plutons emplaced during or just prior to tectonic denudation (Banks, 1980; Rehrig and Reynolds, 1980; Gans, 1987; Gans and others, 1989); (c) raised isotherms in response to rapid tectonic denudation of midcrustal levels (Spencer and Reynolds, 1989c). The latter factor alone may be sufficient to explain the available data on geothermometry and geobarometry, but does not preclude a role for the other two.

Mid-Tertiary mylonitic fabrics differ in geometry and intensity from Laramide deformational fabrics inherited by exposed core rocks (Reynolds and others, 1988). Most notably, the older fabrics are more schistose and less lineated, showing evidence for more pure flattening and less rotational shear during their formation. In the Catalina core complex, mid-Tertiary mylonitic gneiss derived from plutonic protoliths is typified by relict feldspar augen and elongate quartz ribbons, whereas quartz and feldspar are deformed to comparable degrees in Laramide orthogneiss, in which both minerals occur as porphyroclasts (Bykerk-Kauffman, 1990). The contrast in metamorphic style is attributed to the difference between conditions of prograde metamorphism characteristic for the older fabrics and the distinctly retrograde metamorphism that prevailed during development of the mid-Tertiary fabrics. Appreciation of the systematic differences between the two is a recent insight that now provides a potential tool for refined interpretations of structural relations and tectonic history within core rocks.

\section{Origin of domical morphology}

Perhaps the most puzzling facet of structural geometry related to core complexes is the arching or flexure of detachment faults and associated mylonitic foliation about axes at a high angle to denudational tectonic transport. As a result, mylonitic core rocks exposed within the mapped trace of a detachment surface with an overall domical form can be surrounded on all sides by a marginal zone of faulted cover rocks. Foliation arches and detachment corrugations with axes parallel to slip direction can be understood kinematically as megumullion lineations (Table 6D) that formed during progressive offset along an evolving shear zone and its linked detachment system. However, structural uplift of a detachment surface athwart the direction of tectonic transport (Table 6E) creates the appearance of updip thrust displacement along backtilted segments of the detachment fault. Postslip deformation of the detachment system is required to achieve the observed structural geometry. Several independent ideas, none mutually exclusive, may help explain the widespread domical morphology:

(1) Within a ductile shear zone, the sigmoidal pattern of internal mylonitic foliation feathers out downward in a direction opposed to the net direction of tectonic transport (Davis, 1983). This inherent structural geometry can contribute to the antiformal configuration of foliation trends warped about axes at right angles to the slip direction (Naruk, 1987a, b), but cannot affect the orientations of brittle detachment structures that are superimposed upon the mylonitic deformation.

(2) Broad flexure of the detachment system and underlying mylonite zone by reverse drag or rollover above a listric normal fault cutting deep into the crust below the core complex could produce the domical form observed (Bartley and Wernicke, 1984; Gans and others, 1985; Wernicke and others, 1985; Spencer and Reynolds, 1989c). For this process to serve as a general means to produce features that appear to be so common, subsequent listric faulting must occur systematically for some intrinsic but as yet uncertain reason.

(3) Isostatic upwarping of the detachment system and underlying mylonite zone in response to structural unloading of the core rocks as a result of tectonic denudation appears now to be the most general hypothesis available for the widespread domical morphology (Spencer, 1984). The process represents postulated behavior that can be regarded as intrinsic to the fundamental processes of extensional tectonism giving rise to core complexes (Rehrig and Reynolds, 1980; Rehrig and others, 1980; Howard and others, 1982b; Spencer, 1985; Wernicke, 1985; John, 1987).

The high elevation of many ranges where the centers of core complexes are exposed is not explained, however, by any of the rationales for relative upbowing of detachment faults and mylonite zones. Crustal attenuation accompanying tectonic denuda- 
tion should lead ultimately to elevations distinctly lower than adjacent ground where the crust was not markedly thinned by extension (Barr, 1987). The lack of an expected contrast in elevation and inferred crustal thickness between extended and unextended ground seemingly implies ductile flowage of the hidden lower crust. Crustal flowage could compensate for changes in crustal profile produced by tectonic denudation associated with structural extension at shallower crustal levels (Gans, 1987; Howard and John, 1987; Spencer and Reynolds, 1989c).

Recent analysis (Wallace and others, 1986; Holt and others, 1986) of local geophysical data suggests that: (1) the crust beneath much of the Catalina core complex is actually thicker than in surrounding areas, (2) isostatic uplift in response to midTertiary tectonic denudation produced only a broad subregional flexure with modest positive relief (perhaps similar to the modern Tortolita Mountains at the western end of the core complex), and (3) the sharper relief of the present Santa Catalina and Rincon mountains was produced by delayed isostatic uplift that occurred later in Cenozoic time when basin-range block faulting ruptured the crustal profile and thereby reduced its flexural rigidity.

In sum, the overall domical morphology and associated high relief of typical core complexes may stem from a combination of related but different factors including the initial sigmoidal pattern of mylonitic foliation within ductile shear zones, rollover rotation above deeper listric structures, broad isostatic upwarping in response to tectonic denudation, and local isostatic uplift of anomalous crustal masses during surficial erosion of tectonically denuded cores (cf., G. A. Davis and others, 1986; G. A. Davis and Lister, 1988; Reynolds and Lister, 1990). All these factors probably contributed to the present morphology of the Catalina core complex.

\section{Occurrence of mylonitic gneiss}

Many structural details of the mylonitic gneiss zone and the detachment fault system bounding the Catalina core complez remain subject to further interpretation with additional data, but the overall distribution of mid-Tertiary mylonitic fabric and the general configuration of the master detachment fault are well established (Fig. 13). Mylonitic gneiss along the southwest flank of the exposed core occupies an outcrop belt, continuous except where interrupted by post-mid-Miocene cover, about $10 \mathrm{~km}$ wide and $100 \mathrm{~km}$ long. Along the southwest side of this outcrop belt, mylonitic foliation dips gently $\left(\sim 20^{\circ}\right)$ to the southwest and mylonitic lineation trending $S 60^{\circ}-65^{\circ} \mathrm{W}$ plunges gently downdip. S-C fabrics uniformly indicate displacement (top over bottom) down to the WSW (parallel to lineation). The Catalina detachment fault delimits exposures of mylonitic gneiss on the southwest, and typically dips slightly more steeply ( 25 to $35^{\circ}$ ) than foliation in the underlying mylonitic gneiss (Voelger, 1953; Pashley, 1966). Around Redington Pass and in the Rincon Mountains farther south (Fig. 13), antiforms and synforms, defined both by foliation surfaces in mylonitic gneiss and by wavelike corrugations in the detachment surface, trend and plunge subparallel to mylonitic lineation. An analogous synform of even larger scale apparently accounts for the prominent scoop or spoon in the main detachment surface between the Tortolita and Suizo mountains on the northwest (Fig. 13).

Along the northeast side of the belt of mylonitic gneiss, mylonitic fabric is less intense than in outcrops closer to the detachment fault, and mylonitic foliation dips gently $\left(\sim 15^{\circ}\right)$ to the northeast. In the Catalina forerange especially (Fig. 13), attitudes of foliation describe a broad arch trending subparallel to the Catalina detachment fault. Some component of the arching is doubtless the result of broad flexure of the entire detachment system. However, in road cuts below Windy Point (Fig. 13) along the highway to Mount Lemmon, well-exposed mylonitic foliation dipping northeast into the range decreases in intensity downdip as leucocratic gneiss passes laterally into massive rock of the Wilderness granite suite. A similar relationship exists along the trend of Tanque Verde Ridge as it rises toward Mica Mountain (Fig. 13) south of Redington Pass.

At least in these localities, some component of the progressive arching of mylonitic foliation from southwest to northeast dips is inferred here to reflect sigmoidal curvature of foliation as it feathers out downward toward the margin of an exhumed ductile shear zone. The geometry observed is the configuration expected for mylonitic foliation in the lower half of an extensional shear zone that was inclined toward the southwest subparallel to the structurally overlying detachment fault (G. H. Davis, 1983). Observed relations imply that the ductile part of the shear zone at depth within the crust must have been 2.5 to $5 \mathrm{~km}$ thick.

Detailed study has revealed, however, that opposed dips of mylonitic foliation in the Catalina forerange are related in part to the development of an antithetic or conjugate shear zone within the belt of ductile strain (Naruk, 1987b; Naruk and BykerkKauffman, 1990). Late-stage antithetic zones of penetrative shear also developed in other core complexes as flexure during tectonic denudation folded the mylonitic domain of ductile strain within the crust (Reynolds and Lister, 1987). Mylonitic foliation may also become backtilted as isostatic upwarp of denuded core rocks proceeds (Reynolds and Lister, 1990). Intricately gradational contacts between undeformed two-mica granite of the Wilderness granite suite and deformed leucocratic gneiss near Redington Pass and in the Little Rincon Mountains (Fig. 13) provide evidence for heterogeneous strain within the Catalina core complex as a whole.

Plutonic protoliths of mylonitic gneiss exposed along the flank of the Catalina core complex include granitic rocks of the megacrystic middle Proterozoic Oracle/Ruin granite suite, more mafic Laramide intrusions, the peraluminous middle Eocene Wilderness granite suite, and the composite mid-Tertiary batholith of Catalina and Tortolita granite (Banks, 1980; Keith and others, 1980). The most widespread mylonitic rocks are dark augen gneiss of Oracle/Ruin protolith and leucocratic garnetiferous gneiss of Wilderness protolith. The two gneissic phases are commonly interleaved intimately on the outcrop, and the mylonitic fabric is generally more intense in the more micaceous augen 
gneiss than in the quartzofeldspathic leucocratic gneiss. This fact has led many to suppose that the Oracle/Ruin protolith experienced an episode of deformation that occurred prior to emplacement of the Wilderness bodies (Keith and others, 1980). In all cases, however, adjacent masses or tabular bodies of augen gneiss and leucocratic gneiss display fabric elements of foliation and lineation whose geometric orientations are strictly parallel and fully compatible with the same pattern of strain. Accordingly, I conclude that both of the two most abundant protoliths were deformed together in mid-Tertiary time, but developed mylonitic fabrics of differing intensity simply because the two parent rock types responded somewhat differently to the same episode of deformation.

Many bodies of leucocratic gneiss derived from Wilderness protolith are quasitabular, in contact with augen gneiss of Oracle/ Ruin protolith on both sides. Those with northwesterly strikes are sills that lie subparallel to pronounced foliation in the enclosing augen gneiss, and display internal foliation oriented subparallel to

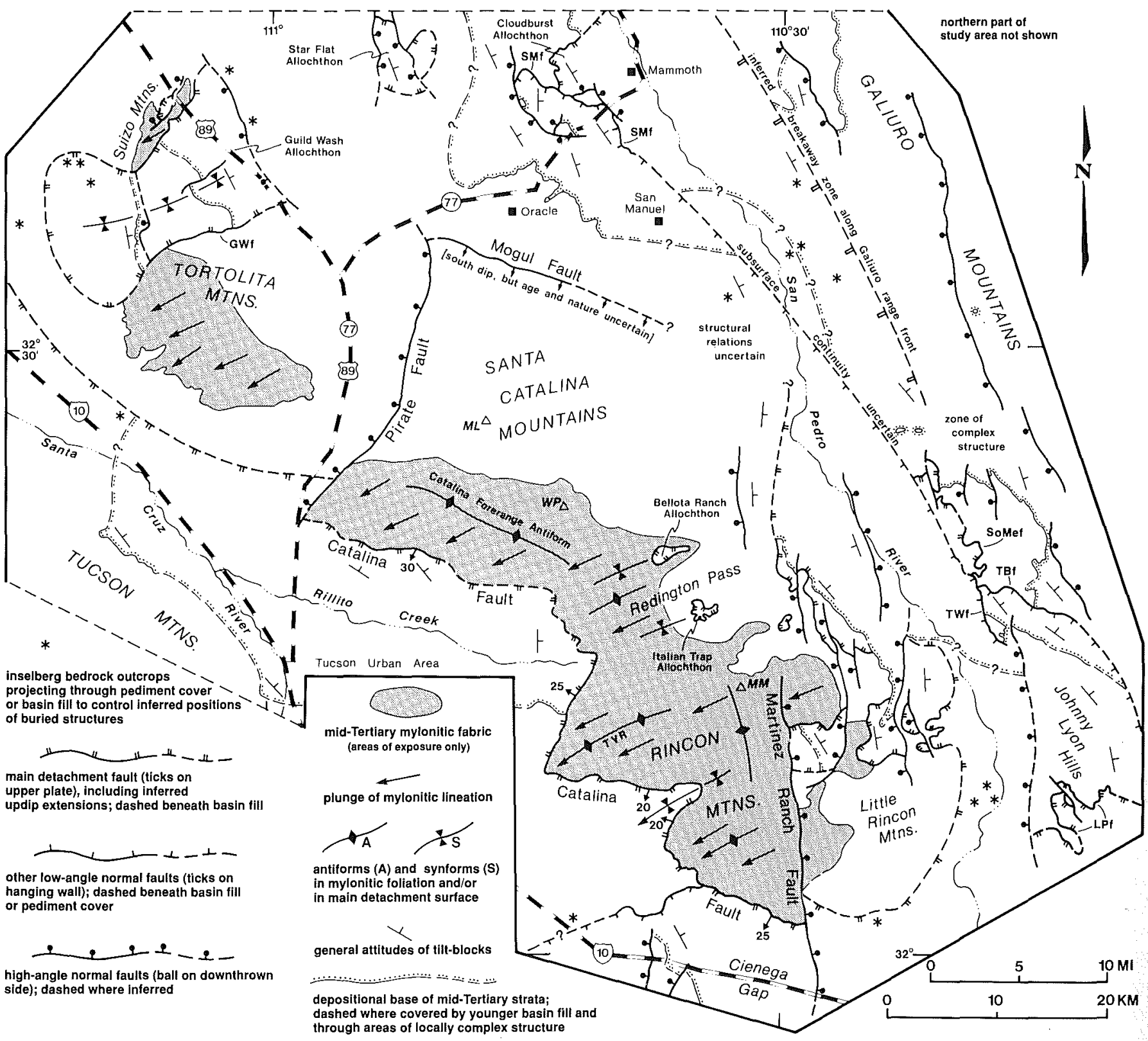

Figure 13. Configuration of the detachment fault system associated with the Catalina core complex. Selected faults shown: GWf, Guild Wash fault; LPf, Lime Peak fault; SMf, San Manuel fault; SoMef, Soza Mesa fault; TBf, Teran Basin fault; TWf, Teran Wash fault. Guild Wash, Star Flat, Cloudburst (or Tar Wash), Bellota Ranch, and Italian Trap allochthons are erosionally isolated outliers of cover rocks lying structurally above detachment surfaces. Localities noted in text: ML, Mount Lemmon; MM, Mica Mountain; TVR, Tanque Verde Ridge; WP, Windy Point. 
generally planar sill margins. Those with northeasterly strikes are sinuous or folded dikes that lie athwart foliation in the enclosing augen gneiss, and display internal foliation that cuts through the dikes along trends parallel to foliation in the augen gneiss but at high angles to irregular dike margins. The sills were presumably rotated into their present alignments subparallel to mylonitic foliation by extreme ductile strain, but their present aspect ratios may be poor guides to their original shapes. The dikes, with strike generally parallel to mylonitic lineation, were unable to rotate into parallelism with mylonitic foliation during ductile strain. Instead, they were crumpled by subvertical flattening into irregular folds with subhorizontal axes that trend northeast, generally parallel to transport direction within the controlling ductile shear zone.

\section{Conditions of mylonitic deformation}

Limited geobarometric data suggesting the formation of exposed mylonitic fabrics in the Catalina core complex at depths of 8 to $12 \mathrm{~km}$ (Anderson and others, 1988), or perhaps $15 \mathrm{~km}$ (Anderson, 1988), are broadly compatible with mapped geologic relationships. Given the estimated stratigraphic thickness of the pre-Laramide sedimentary succession above basement as 3 to 4 $\mathrm{km}$, the geobarometric data seemingly imply that mylonitic shear to produce the observed gneissic fabric occurred at a structural level 5 to $10 \mathrm{~km}$ down into Precambrian basement intruded by various Phanerozoic plutons. However, Laramide thrusts now exposed along the northeastern flank of the Santa Catalina Mountains probably thickened the stratified rocks overlying Precambrian basement to a structural thickness of 5 to $6 \mathrm{~km}$ prior to mid-Tertiary tectonic denudation. This inference is supported by the fact that simple scaling of maps and cross sections (e.g., Fig. 1) shows that mylonitic fabric is present locally in basement plutons lying no more than 2 to $3 \mathrm{~km}$ structurally below the depositional base of metamorphosed strata in core rocks. Moreover, the present tilt of the mountain block suggests that the mid-Tertiary mylonitic belt of the Catalina forerange probably formed over a depth interval of 5 to $7.5 \mathrm{~km}$. Summing depth estimates for different structural horizons within the core rocks yields predicted depths for mid-Tertiary mylonitic deformation in the range 7.5 to $12.5 \mathrm{~km}$, in reasonable agreement with available geobarometry.

Temperatures within the local crustal profile were doubtless influenced by advective heat transferred upward by injection of Tertiary plutons, but further thermokinematic analysis is required to specify that influence within useful limits. Relations in both time and space are complex. On the one hand, large plutonic bodies of the Wilderness granite suite are widespread within core rocks, and at least locally were emplaced at high enough structural levels to intrude metasedimentary rocks cut by Laramide thrusts. Their intrusion, however, largely predated post-Laramide cooling and uplift. Laramide metamorphic detritus was contributed to mid-Tertiary syntectonic strata by early Miocene time. On the other hand, mid-Tertiary plutons that locally display mylonitic fabric are confined, so far as now known with certainty, to the western Santa Catalina and southern Tortolita mountains where their presence could not have had much effect on thermal conditions elsewhere within the Catalina core complex. Current geobarometric evidence for the depths of emplacement of the two Tertiary plutonic assemblages permits several kilometers of uplift and erosion between Laramide orogenesis and mid-Tertiary taphrogenesis.

\section{Configuration of detachment system}

The Catalina detachment fault dips off the flank of the Catalina core complex beneath cover rocks underlying the Tucson Basin. Downdip extensions are nowhere exposed to view. On the south, the trace of its updip extension curves around the eastern side of the Rincon and Little Rincon mountains, where the detachment fault has been backtilted to gentle easterly dips by postdetachment deformation (San Pedro detachment fault of Lingrey, 1982). Several backtilted segments have been repeated by post-detachment normal faulting east of the crest of the Rincon Mountains (Fig. 13). Exposed traces of the backtilted detachment system extend almost continuously northward as far as the east side of Redington Pass. Erosional outliers or klippen of cover rocks are exposed as the Bellota Ranch and Italian Trap allochthons, overlying nearly flat segments of the detachment fault preserved within local synforms in the Redington Pass area (Benson, 1981).

Along tectonic strike to the northwest, segments of the detachment fault bound exposures of the Guild Wash allochthon, which occupies the broad synformal downbow between the Tortolita and Suizo mountains (Fig. 13). Updip extensions of this part of the detachment system, in the area north of the Catalina core complex, underlie the Star Flat allochthon northwest of Oracle and the Cloudburst or Tar Wash allochthon near Mammoth. The detachment surface is backtilted to gentle northeasterly dips beneath the Guild Wash, Star Flat, and Cloudburst allochthons. As the same mid-Tertiary stratigraphic succession is exposed in all three of these allochthons, they evidently were separated by subsidiary splay faults that repeated the section but have been removed from view by subsequent erosion. Alternatively, each of the three allochthons may be floored structurally by discrete members of an array of associated rotational normal faults, each of which originally dipped more steeply than at present.

The nature of the continuation of the detachment system eastward across the San Pedro River is uncertain. A headwall breakaway zone (Fig. 13) is inferred to lie beneath basin fill along the Galiuro range front. Exhumed bedrock tilt-blocks, which project locally through eroded basin fill within the San Pedro trough, display markedly steeper northeast dips $\left(30\right.$ to $50^{\circ}$ ) than correlative strata that are nearly flat-lying $\left(\sim 10^{\circ}\right)$ within the Galiuro Mountains. Farther south, the gently dipping (10 to $20^{\circ}$ ) Soza Mesa and Lime Peak low-angle normal faults are inferred to represent updip segments or strands of the detachment system where it approached the surface. However, both the latter struc- 
tures are offset by mapped or inferred younger normal faults aligned along the eastern flank of the San Pedro trough; their continuity with the detachment fault exposed west of the San Pedro trough cannot be proved with present data.

Throughout the area surrounding the Catalina core complex, syntectonic mid-Tertiary deposits and older strata are broken into numerous tilt-blocks, which strike northwest and dip northeast, by multiple normal faults that also strike northwest but dip southwest at varying angles. The depositional contact at the base of the mid-Tertiary succession is repeated several times by these faults along any transect crossing the area parallel to the direction of net tectonic transport (Fig. 13). Some gently to moderately dipping normal faults were apparently active during detachment faulting and terminate downward at the detachment surface, as within the Guild Wash allochthon (Fig. 13), but others offset the detachment surface and must be somewhat younger structures. Most significant among the latter are the San Manuel fault, exposed between Oracle and Mammoth north of the Catalina core complex, and its inferred counterparts to the south (the Teran Wash and Teran Basin faults). These moderately dipping ( 25 to $35^{\circ}$ ) faults cut structurally beneath the Catalina core complex, and tilt of the crustal block above them may account in part for backtilt of the detachment system as a rollover effect. The dip of Miocene strata resting unconformably on Precambrian basement along the northeast flank of the Santa Catalina Mountains (Fig. 1) suggests that the mountain block, including the Catalina core complex, has been tilted 15 to $20^{\circ}$ to the northeast.

Postdetachment faulting along the San Pedro trough may also account for the divergence between the $\mathrm{N} 30^{\circ}-40^{\circ} \mathrm{W}$ trend of the breakaway zone along the Galiuro range front and the $\mathrm{N} 50^{\circ}$ $60^{\circ} \mathrm{W}$ trend of the axis of the Catalina core complex. Net fault displacements that increased northward on the San Manuel and related faults may have accommodated counterclockwise rotation of the core complex with respect to the Galiuro Mountains block (Spencer and Reynolds, 1989c).

Younger, more steeply dipping normal faults strike roughly north-south, with downthrown blocks both to the east and to the west in different instances, and locally offset nearly flat-lying basin fill as well as older tilted strata. These structures represent the local effects of the post-mid-Miocene basin-range deformation that postdated mid-Tertiary taphrogeny. The two faults of this generation with greatest displacements are the Martinez Ranch and Pirate faults (Fig. 13), which border the most elevated parts of the Rincon and Santa Catalina mountains, respectively. Offsets of rock units imply structural relief of 3 to $5 \mathrm{~km}$ across both structures. The areas of high relief adjacent to the two faults are separated by the more subdued topography of Redington Pass, which occupies a low sag between abruptly uplifted masses adjacent to fault-controlled escarpments facing in opposite directions. Buried basin-range faults of uncertain but lesser displacement underlie basin fill within the Tucson Basin southwest of the Catalina core complex (Anderson, 1987).

\section{Displacement along detachment fault}

The distribution of Proterozoic granitic suites in the Precambrian basement (Fig. 7) exposed across the Rincon Mountains suggests a net cumulative offset of at least $27.5 \mathrm{~km}$ and perhaps as much as $35 \mathrm{~km}$ along the Catalina detachment fault (Fig. 14). The larger value would require restoration of rock masses in the upper plate from present positions within or near Rincon Valley on the western flank of the range to initial positions above the location of the current San Pedro trough bounding the eastern flank of the range. Unfortunately, the geometry of contacts between rock bodies within the Precambrian basement is not known well enough to establish unequivocally the actual amount of offset. Total displacement within the suggested range is compatible, however, with previous estimates based on kinematic analysis of strain indicators in mylonitic gneiss of the Catalina forerange (Naruk, 1987b), and on apparent offset of presumably correlative pre-Tertiary structural features exposed east and west of the Rincon Mountains (Krantz, 1983). The inferred slip incorporates an uncertain but significant amount of distension of the upper plate of the detachment system by multiple offsets along splay faults branching upward into cover rocks.

For the Santa Catalina Mountains farther northwest, offset relations across the detachment fault are more difficult to constrain. A displacement of not more than $20 \mathrm{~km}$ is preferred here because greater offset would imply restoration of the rock assemblage exposed in the Tucson Mountains (Figs. 1 and 2) to a position structurally above core rocks of the Santa Catalina Mountains. However, a restoration of 40 to $45 \mathrm{~km}$ of movement parallel to the slip direction of $560^{\circ}-65^{\circ} \mathrm{W}$ defined by the trend of mylonitic lineation would be required to place the Laramide Amole pluton of the Tucson Mountains above the closest known Laramide intrusive bodies exposed along the travel path (Fig. 9). This Laramide igneous assemblage and its wallrocks along the eastern flank of the Santa Catalina Mountains bear no close resemblance to Laramide and associated rocks of the Tucson Mountains (Tables 4 and 5) and the implied correlation is thus not attractive. Moreover, comparable offset of 40 to $45 \mathrm{~km}$ for cover rocks exposed in Rincon Valley and Cienega Gap southwest of the Rincon Mountains would require their restoration to an unlikely initial position beyond the Johnny Lyon Hills, and thus well east of the San Pedro trough (Fig. 13).

Geologic relations across the Guild Wash segment of the detachment fault between the Tortolita and Suizo mountains (Fig. 13) imply a total displacement of at least $10 \mathrm{~km}$ but probably not more than $20 \mathrm{~km}$. The net displacement of the Cloudburst allochthon (Fig. 13) away from the Galiuro Mountains by movement along the Cloudburst segment of the detachment fault is also constrained to 10 to $20 \mathrm{~km}$ by the lateral extent of the allochthon, together with its present location with respect to the Galiuro range front.

Therefore, cumulative displacements across the detachment 


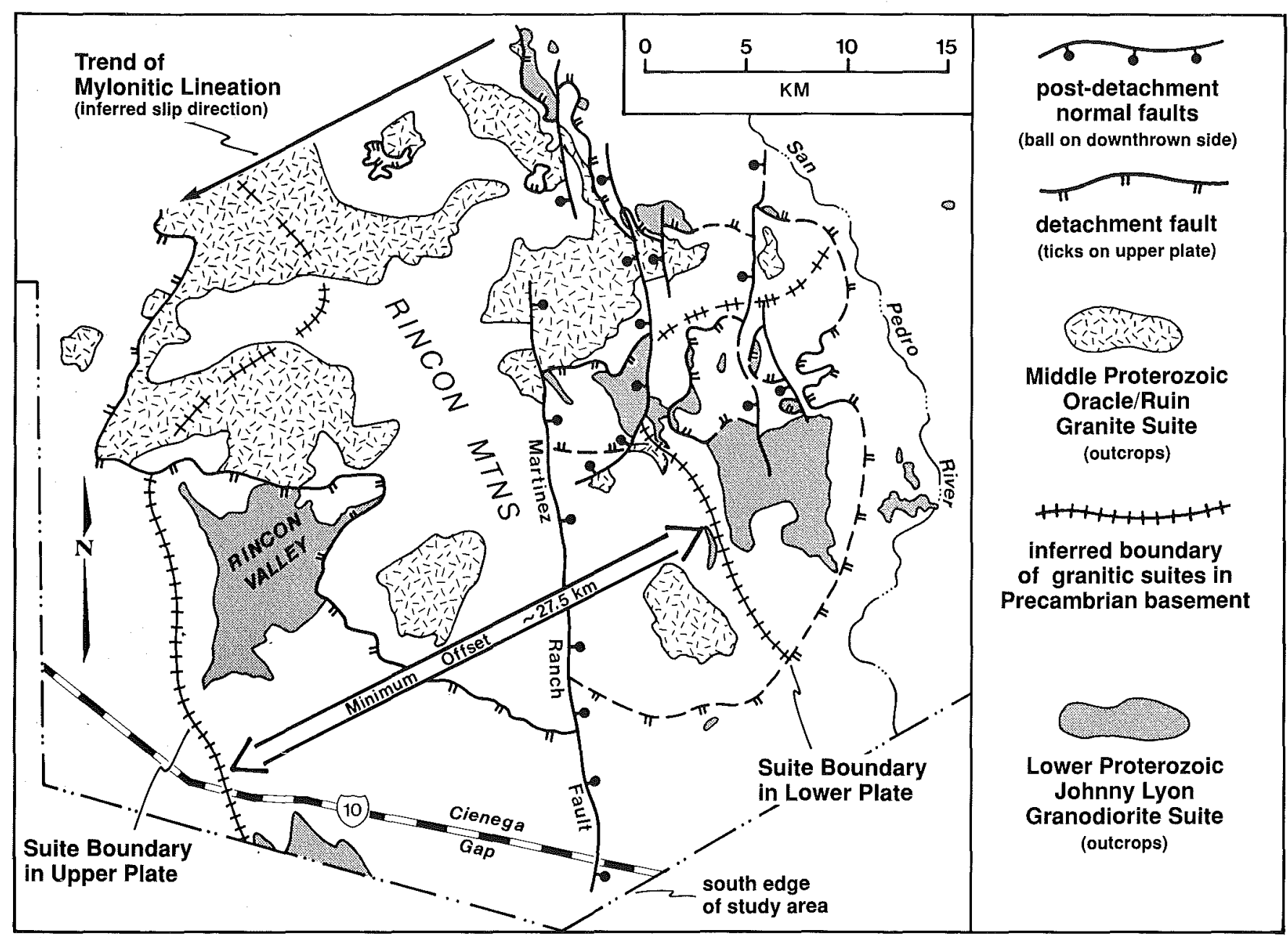

Figure 14. Inferred offset by detachment fault of key Proterozoic granitic suites across Rincon Mountains southeast of Tucson; see text for discussion.

system of the Catalina core complex are estimated to have been 20 to $30 \mathrm{~km}$, with greatest net slip across the Rincon Mountains on the southeast and lesser slip farther to the northwest along the flanks of the Santa Catalina and Tortolita Mountains. Decreasing offset along the main detachment fault toward the northwest may have been compensated, in terms of net crustal extension, by increasing offsets toward the northwest on multiple low-angle normal faults aligned along the San Pedro trough.

As displacements across branching splay faults cutting upward into cover rocks were presumably additive downdip along the master detachment fault, progressively lesser displacements are inferred for successive updip segments of the detachment system. As a result, some individual allochthons perched upon strands of the detachment system lying above core rocks exposed in the interior of the core complex reflect lesser net slip. For example, the rock assemblages that make up the Bellota Ranch and Italian Trap allochthons in the Redington Pass area (Fig. 13) closely resemble those in outcrops along the eastern side of the pass only $10 \mathrm{~km}$ away in the direction of tectonic transport, but could not have been derived from any farther east.

\section{Timing of tectonic denudation}

Geochronological data (Fig. 15) constrain the formation and denudation of mylonitic gneiss along the southwest flank of the Catalina core complex within tight limits. Gneisses derived from plutonic protoliths ranging from middle Proterozoic to middle Eocene in age of emplacement have all had their K-Ar clocks reset to Oligocene ages. Mid-Tertiary granite with a latest Oligocene emplacement age also displays mylonitic fabric in exposures within the exhumed shear zone that trends along the range front of the Tortolita Mountains. Unfoliated dikes that crosscut mylonitic foliation yield earliest Miocene K-Ar ages (21 to $24 \mathrm{Ma}$ ) at widely separated localities in the Tortolita, Santa Catalina, and Rincon mountains (Reynolds and others, 1986a, \#534, \#645, \#658).

Available data permit the simple hypothesis that rapid shear and tectonic denudation occurred near the Oligocene-Miocene time boundary, with older $\mathrm{K}-\mathrm{Ar}$ ages for some gneisses interpreted as partially reset dates. A more complex alternate hypothesis is preferred. The mylonitic fabric in deformed mid-Tertiary 


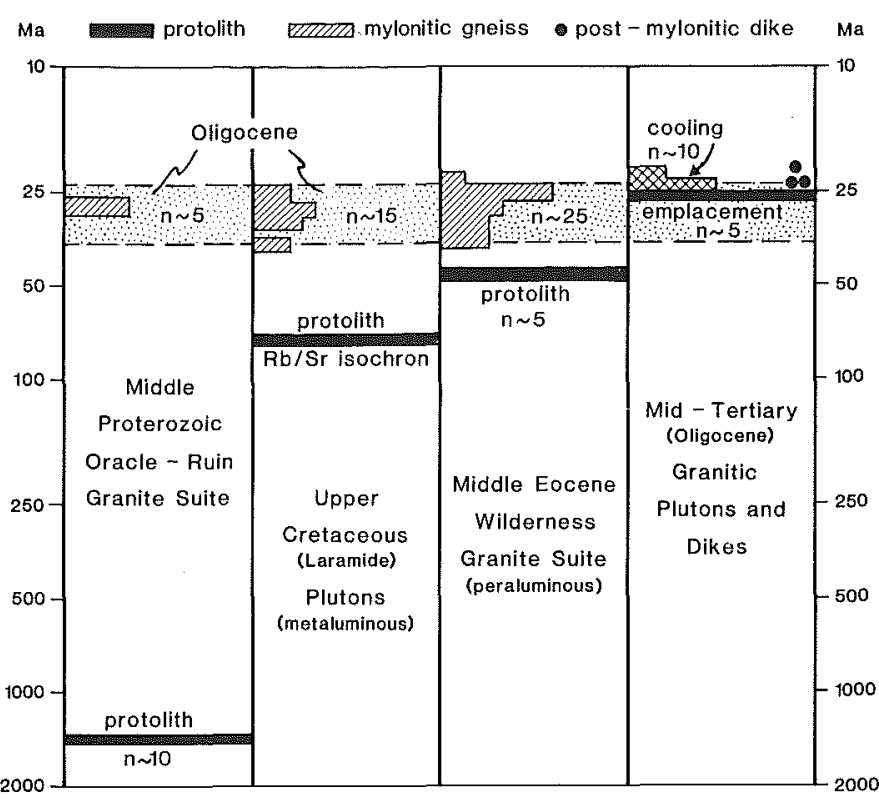

Figure 15. Radiometric ages (total $\mathrm{n} \sim 75$ ) for varied protoliths and derivative mylonitic gneisses of diverse lithology exposed structurally beneath the detachment fault within the Catalina core complex. Data from Banks (1980), Keith and others (1980), and Reynolds and others (1986a). Note logarithmic age scale. Protolith ages (see text) inferred from combined $\mathrm{U}-\mathrm{Pb}, \mathrm{Rb}-\mathrm{Sr}$, and $\mathrm{K}$-Ar data; all mylonitic, cooling, and dike ages plotted are $\mathrm{K}-\mathrm{Ar}$ ages but available fission-track ages are comparable.

granite is generally less intense than the mylonitic fabric of gneisses derived from older protoliths. This contrast suggests that protracted mylonitic deformation occupied some presently indeterminate interval of late Oligocene time, and that plutons not emplaced until latest Oligocene time did not experience as much strain as did older wallrocks. In this viewpoint, continued tectonic denudation is inferred to have brought the mylonitic rocks upward across the brittle-ductile transition by the end of Oligocene time, and thus into position to be intruded by unfoliated dikes of earliest Miocene age (21 to $24 \mathrm{Ma}$ ). Recently reported Miocene $\mathrm{K}$-Ar ages (20 to $21 \mathrm{Ma}$ ) for new-grown illite in fault gouge exposed along the Catalina detachment fault (Shafiqullah and others, 1988) are interpreted to reflect further sequential evolution of the brittle-ductile shear zone as tectonic denudation progressively unroofed the core rocks during early Miocene time.

Mid-Tertiary mylonitic deformation and associated detachment faulting related to evolution of the Catalina core complex thus began after $30 \mathrm{Ma}$ but before $25 \mathrm{Ma}$ in late Oligocene time, and continued for not less than 5 m.y., and perhaps for 10 m.y., until at least $20 \mathrm{Ma}$ in early Miocene time. Geochronological evidence (Reynolds and others, 1986b; G. A. Davis and others, 1986; G. A. Davis, 1988; G. A. Davis and Lister, 1988) that mylonitic deformation and tectonic denudation spanned or postdated the Oligocene-Miocene time boundary has also been reported for core complexes at South Mountain near Phoenix and in the Whipple Mountains near the Colorado River (Fig. 3B). Sedimentological features and structural relationships of tilted mid-Tertiary stratigraphic sequences in the southern Basin and Range province are thus capable of providing important information about near-surface structure and topography during the evolution of core complexes at depth.

\section{ALTERNATE STRUCTURAL MODELS}

Different models for the structural evolution of extensional detachment fault systems are based on different concepts of lowangle normal faulting (Fig. 16). Some workers hold that normal displacements can occur on surfaces with gentle dips approaching subhorizontal (Fig. 16A), whereas others assume that such gentle dips are only attained by rotation of steeper faults that become inactive as their dips are reduced (Fig. 16B). The two different points of view embody contrasting implications for tilt and denudation of core rocks. Moreover, the inference that postslip deformation has affected the dip of mapped detachment faults requires diachronous histories of displacement along observed detachment surfaces.

The gross geometry of the Catalina core complex favors the standard detachment model (Fig. 16A) over the alternate extensional model (Fig. 16B). Nevertheless, structural and stratigraphic relationships of syntectonic mid-Tertiary sequences afford potential means to test alternate predictions in detail. Areal variations in age, thickness, and facies provide information about the inception and evolution of half-graben basins, and the geometry of exposed tilt-block homoclines provides information about the configuration of controlling structures. Discussion of alternate models for structural development of core complexes is thus appropriate before considering the stratigraphic and structural relations of syntectonic strata.

\section{Unidirectional tilt domains}

Domains of severe extensional strain are commonly marked at shallow crustal levels by subparallel arrays of normal faults dipping in the same direction. Although strain may hypothetically be initiated by a conjugate fault system, unidirectional dip of families of active faults evolves as strain continues in order to avoid having faults cross each other and lock up (Jackson and McKenzie, 1983). As a result, taphrogenic provinces are characteristically subdivided into areally extensive tilt domains within which tilt-blocks are inclined in the same direction and separated by simple half-grabens, or in some cases by complex grabens that are markedly asymmetric (Stewart, 1980). Opposing tilt domains are delimited along strike by strike-slip transfer faults, variably deformed accommodation zones, or locally warped hinge zones (Gibbs, 1984; Bosworth, 1985). Blind transfer faults may be marked near the surface by abrupt monoclinal flexures (Leeder and Gawthorpe, 1987). Varied arrays of tilt domains have been described within the Basin and Range province and along the Rio Grande rift belt of the intermountain region (Stewart, 1980; Chapin, 1988, 1989; Spencer and Reynolds, 1989c, 1991). 
Amounts and patterns of tilt of offset strata within a single tilt domain may reflect two distinct controls of stratal tilt related to arrays of normal faults exhibiting different behavior (Verosub and Moores, 1981; Wernicke and Burchfiel, 1982; Cape and others, 1983). On the one hand, tilt can result from inherently rotational displacement of hanging-wall blocks above curviplanar or listric normal faults by reverse drag (Hamblin, 1965) to resolve the spatial room problem created by offset. Internal and comparative tilts of fault blocks bounded by parallel traces of listric faults that moved in the same sense will vary as a function of the curvatures of the faults, their lateral spacings, and the amount of displacement on each fault.
A

1) initial configuration of detachment system

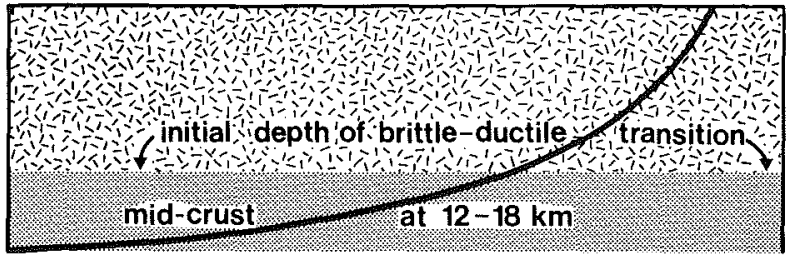

2) thin wedge of upper plate distended by multiple tilt-blocks bounded by listric and/or rotational faults

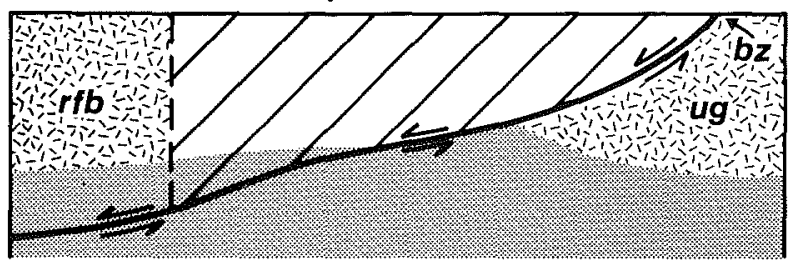

3) isostatic upwarp of detachment system causes antiformal uplift and synclinal downbow to lock up

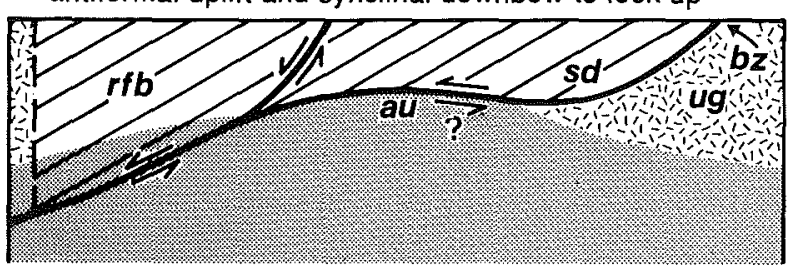

4) one-sided tectonic denudation of one flank of core complex continued beyond secondary breakaway

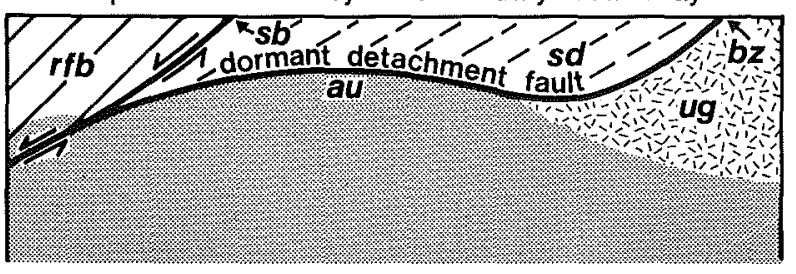

$25 \mathrm{KM}$
B

1) initial fault set prior to motion

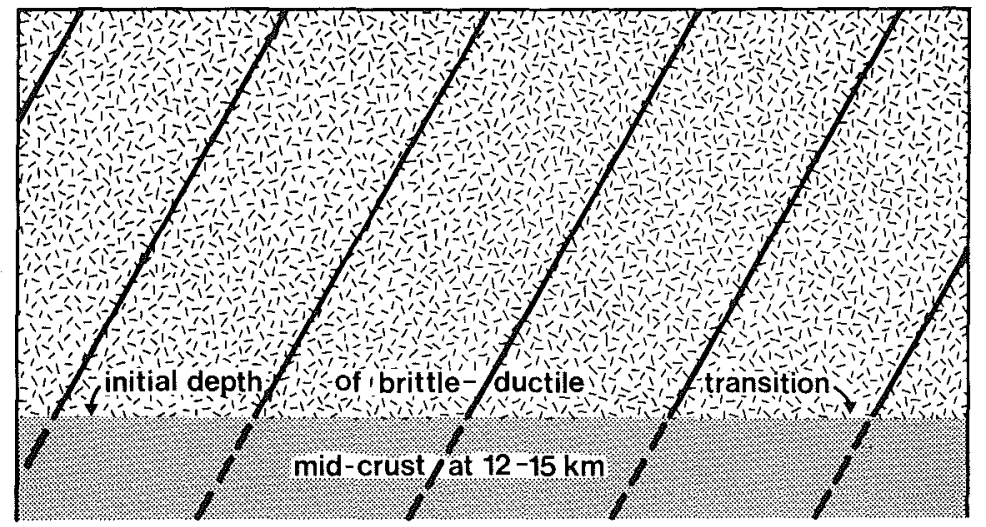

2) active rotated fault set solid; incipient superposed fault set dashed

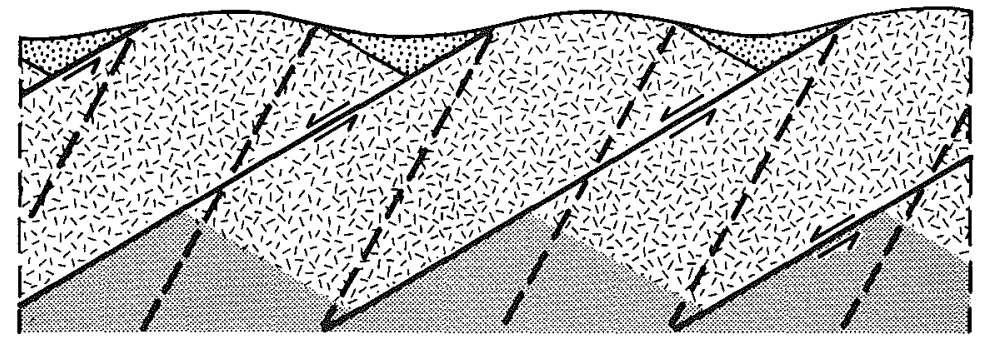

3) active superposed fault set solid; inactive rotated fault set dashed

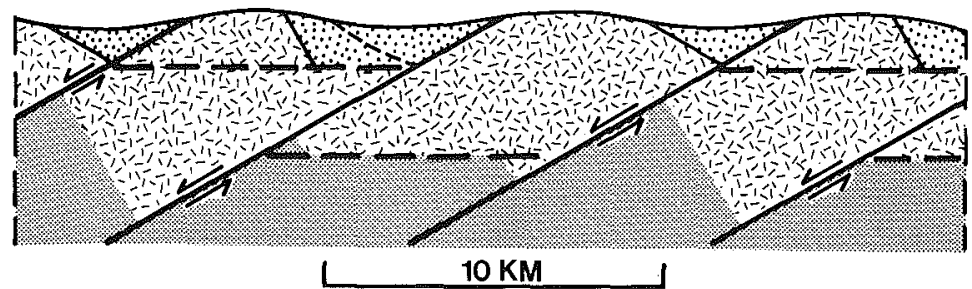

Figure 16. Alternate (A and B) structural models (stages 1 to 4 and 1 to 3 , respectively) for tectonic denudation of midcrustal rocks in Cordilleran metamorphic core complexes (note different scales): A, isostatic upwarp of lower plate of gently dipping detachment fault during progressive unloading of midcrust by lateral transport of upper plate internally distended by either curviplanar listric or rotational planar normal faults denoted schematically only; B, successive rotation of multiple tilt-blocks bounded by superposed generations of rotational normal faults accommodating bulk crustal extension. Geometric display of both sets of sequential diagrams adjusted to allow uplift of midcrustal rocks to one-third of their initial depth (nominally $4 \mathrm{~km}$ versus $12 \mathrm{~km}$ ). Actual position of brittle-ductile transition within crust during structural evolution of alternate systems depicted would depend largely on strain rate. Sy;mbols for A: bz, breakaway zone; ug, unextended ground; rfb, rooted fault block; sd, synformal downbow; au, antiformal uplift; sb, secondary breakaway. For B, stipples denote sedimentary fill of tilted half-graben basins for which sediment volume shown is balanced with the amount of material removed by erosion from tilt-block crests (note that different spacing of faults and/or different placement of superposed faults could yield markedly different inferred geometry). 
On the other hand, tilt can also be achieved by rotating an array of planar faults, together with the intervening fault blocks, as fault displacements occur (Ransome and others, 1910; G. H. Davis, 1983; Gans and Miller, 1983). Such a process has been likened to the toppling of a deck of cards, a shelf of books, or a row of dominoes. In the ideal case, an array of tilt-blocks bounded by parallel planar normal faults that moved and rotated in the same sense will acquire a common inclination that does not vary from block to block or within blocks. Actual field relations can be ambiguous because listric faults may undergo subsequent bulk rotation (Anderson, 1971), and planar faults may undergo differential rotation related to their relative spacing or to their respective positions within a heterogeneous strain field. The potential ambiguity is underscored by the additional observation that downdip curvatures of truly listric faults are commonly no more than 5 to $10^{\circ} / \mathrm{km}$ (Proffett, 1977; Chamberlin, 1983).

In general, however, the observed dip of a low-angle segment of a curviplanar listric fault is some measure of the structural level of local exposure, whereas the observed dip of a rotated planar fault incorporates some measure of the total amount of synslip and postslip rotation that modified its initial dip. Termination of slip on normal faults that rotated to dips gentle enough to cause them to lock up is commonly succeeded by initiation of slip on subsequent multiple generations of steeper faults that are superposed across tilted arrays of the older inactive structures (Morton and Black, 1975; Proffett, 1977; Gans and Miller, 1983; Chamberlin, 1983; Gibbs, 1984). Faults that initiate at steep dips near $60^{\circ}$ (Fig. 16B) can evidently remain active until they rotate to dips as gentle as $30^{\circ}$ before a subsequent generation of similar faults is superposed across them (Jackson, 1987). Subsequent rotation of the superposed faults causes continued rotation of the inactive faults as well. Local antithetic faults may also rotate to show apparent reverse slip (Jackson and McKenzie, 1983; Chamberlin, 1983).

Essentially all modern descriptions and discussions of Cordilleran metamorphic core complexes conclude that tectonic denudation was accomplished by unidirectional tectonic transport of cover rocks to exhume midcrustal core rocks by translational movement of distended cover rocks (Lister and Davis, 1989). No kinematic evidence exists for bidirectional denudation such as might occur over a diapiric gneiss dome. Each core complex lies within a single tilt domain (Fig. 3B), and mylonitic fabric is consistently most pronounced along the flank of the core adjacent to the segment of the bounding detachment system that lay farthest downdip prior to domical arching (Wust, 1986b). Still at issue, however, is the question of the dip of the detachment surface while slip along it was underway. Given the clear and universal evidence for postslip deformation during domical arching, the necessity for hypothetical reconstructions based on theory, field relations, or both cannot be avoided.

\section{Inclination of detachment surfaces}

There are two extreme viewpoints, as well as hybrid interpretations that incorporate logical elements of both, regarding the inclination of active detachment faults. The key question turns on whether low-angle normal faults are active at gentle dips, or are merely high-angle normal faults that were rotated to gentle dips as inactive structures (Stewart, 1978).

On the one hand, incontestable evidence for large lateral displacements across detachment systems can be taken to imply movement along subhorizontal detachment surfaces despite the difficulty of explaining the mechanics of such flat faults. In typical core complexes, the large lateral extent ( 25 to $50 \mathrm{~km}$ ) of continuously exposed footwall or core rocks of persistent metamorphic grade seemingly precludes major footwall rotation (Lister and Davis, 1989), which could not occur without exposing downdip crustal granulites or even mantle peridotites (Spencer and Chase, 1989). The strongest actualistic evidence for the existence of subhorizontal detachment structures consists of seismic reflection profiles showing that the Sevier Desert detachment in western Utah dips at an average apparent angle of $12^{\circ}$ across a lateral distance of nearly $75 \mathrm{~km}$ to a depth of 12 to $15 \mathrm{~km}$ below the surface (Allmendinger and others, 1983). Recent mechanical analyses indicate that shear-stress trajectories gentle enough to allow nucleation and propagation of subhorizontal shear fractures might be created where normal faulting: (1) is induced by basal shear traction superimposed on crustal profiles already under deviatoric compressive stress (Yin, 1989); (2) is initiated by extensional strain within crustal profiles already under flexural stresses produced by isostatically uncompensated surface, and especially Moho, relief (Spencer and Chase, 1989); or (3) penetrates viscoelastic crustal layers where rotations of principle stresses can occur (Melosh, 1990). Those who favor the concept that detachment faults bounding mylonitic core rocks were active at low angles have suggested subregional dips of 5 to $25^{\circ}$ during episodes of slip (Wernicke, 1985; Reynolds and Spencer, 1985; G. A. Davis and others, 1986; Howard and John, 1987; G. A. Davis and Lister, 1988; Miller and John, 1988; Spencer and Reynolds, 1991).

On the other hand, it can be postulated that detachment faults initiate at steep dips typical for high-angle normal faults, and rotate later to shallower dips. Perhaps the strongest argument for this postulate stems from first-motion solutions for large modern earthquakes. All such solutions for seismicity generated along active normal faults located within continental blocks imply dips of associated fault planes within the range 30 to $60^{\circ}$, with the mode of all nodal planes being approximately $45^{\circ}$ (Jackson, 1987; Jackson and White, 1989). Strict analogy would dictate that initial dips of brittle detachment faults were also near $45^{\circ}$ (G. H. Davis, 1983, 1987). As the depths of all the relevant earthquake foci are less than 12 to $15 \mathrm{~km}$, the record of seismicity provides no direct information about the geometry of ductile strain at deeper levels.

The dilemma posed by the record of seismicity can be avoided if slip on gently dipping detachment faults is aseismic. Existing models for simple shear of the continental lithosphere along low-angle brittle normal faults and linked ductile shear zones assume the existence of associated high-angle listric or 
planar normal faults. These subsidiary faults extend upward toward the surface from the master detachment surface (Wernicke, 1981, 1985), and could generate seismicity with first motions within the observed spectrum. In addition, the master detachments project to surface breakaway zones where listric headwall normal faults commonly dip within the range 30 to $60^{\circ}$ at shallow crustal levels (G. A. Davis and others, 1980; Howard and others, 1982b).

Downdip relations of subparallel arrays of curviplanar listric or rotating planar normal faults cutting the shallow crust are viewed differently according to whether a discrete subhorizontal detachment fault is thought to exist at depth. If a gentler underlying detachment surface is present, the more steeply dipping highlevel faults are presumed to abut against or merge downward with it (Fig. 16A). Intervening tilt-blocks must then slide downdip along the detachment surface as offsets continue, and net displacements along the detachment fault reflect cumulative slip along the high-level faults. In effect, the latter serve as branches or splays of the detachment system.

If no separate flat detachment is present, however, the brittle high-level slip surfaces are presumed to pass downward into ductile midcrust (LePichon and Sibuet, 1981; Jackson and McKenzie, 1983). This ductile region can be envisioned as involving subhorizontal laminar flowage analogous kinematically to a detachment horizon (Proffett, 1984; Lister and Davis, 1989). Instead, however, it might be a zone of diffuse deformation where shear that is transferred downward along the projected trajectories of brittle high-level faults is dissipated by more complex motions of ductile rock masses (England and Jackson, 1987; Jackson and White, 1989). In this case, faults mapped as gently dipping detachment surfaces are interpreted, together with associated gently dipping mylonitic foliation, as rotated features that evolved while active as more steeply inclined brittle-ductile shear zones (Fig. 16B), Scoop-shaped or shovel-like segments of detachment faults can then be interpreted as backtilted zigzags or doglegs in the traces of steep normal faults (G. H. Davis and Hardy, 1981; Chamberlin, 1983; Gans and Miller, 1983).

Some have suggested that detachment occurs preferentially along or near the crustal horizon marked by the brittle-ductile transition (Miller and others, 1983; Gans and others, 1985). If so, brittle upper crust undergoing markedly heterogeneous deformation could be effectively decoupled from ductile lower crust deforming more homogeneously (Gans, 1987). Moreover, extension of lower crust might involve dilation by igneous intrusions as well as ductile stretching (Lachenbruch and Sass, 1978; Rehrig and others, 1980; Zoback and others, 1981; Eaton, 1982; Gans and Miller, 1983). Associated crustal underplating by igneous bodies trapped near the base of extended crust might combine with ductile flowage to maintain an even crustal profile across extending regions (Gans, 1987).

The brittle-ductile transition in the crust of the modern Basin and Range province is estimated to lie at a depth of 12 to $15 \mathrm{~km}$, above which the crust is seismic and below which it is not (Stewart, 1978; Eaton, 1982; Chen and Molnar, 1983; Smith and
Bruhn, 1984). The best-studied range-front fault, responsible for the 1983 Borah Peak earthquake $(M>7)$ in Idaho, maintains almost constant dip ( 45 to $50^{\circ}$ ) to a comparable depth of 12 to 15 $\mathrm{km}$ (Stein and Barrientos, 1985). Farther south along the intermountain seismic zone, range-front bedrock scarps dip in the range 45 to $75^{\circ}$ and nodal planes defined by first-motion solutions have both mean and median dips in the range 50 to $60^{\circ}$ without evidence for listric behavior (Zoback, 1983). In general, extensional faults capable of storing enough elastic energy to generate major earthquakes by elastic rebound maintain essentially planar paths that cut entirely through the seismogenic crust (Jackson, 1987; Jackson and White, 1989). Using earthquake data alone, however, planar faults cannot be distinguished easily from listric faults with gentle curvature (Jackson and others, 1988).

\section{Evolution of detachment systems}

The overall subhorizontal attitude and characteristic domical morphology of mapped detachment systems can be reconciled with the behavior of modern extensional faults in several different ways. A seemingly fundamental tenet is the idea that structural unloading during tectonic denudation forces isostatic uplift of midcrustal rocks (Spencer, 1984). Otherwise, it is unclear how mylonitic rocks formed by ductile shear at midcrustal levels could ever be juxtaposed at the surface against cover rocks that were never deeply buried.

The most familiar scenario (Fig. 16A) for the evolution of observed detachment systems involves motion along a gently dipping brittle-ductile simple shear, which includes both the detachment fault and a contiguous associated band of mylonitic deformation at greater depth (Wernicke, 1981, 1985). Above the gently dipping crustal shear, which may be aseismic, a tapered wedge of shallow crust is envisioned as distended by multiple internal normal faults. The upward extension of the subhorizontal detachment fault is presumed by most workers to curve in listric fashion to form a more steeply dipping headwall rupture.

As isostatic uplift of tectonically denuded rock masses proceeds, the detachment system evolves into a characteristic set of geometric elements (Fig. 16A after Spencer, 1984, 1985; Spencer and Reynolds, 1990): (1) unextended ground lying beyond the listric headwall of the detachment system; (2) the breakaway zone where listric headwall faults of the detachment system reach the surface; (3) an offset synformal downbow of distended cover rocks stranded kinematically between up-arched core rocks and the breakaway zone; (4) a domical antiformal uplift of core rocks flanked by traces of the deformed detachment fault; and (5) a rooted fault block of cover rocks still poised to continue movement producing further tectonic denudation. Once the deformed detachment surface has been trapped behind isostatically uplifted core rocks, and has locked up beneath the synformal downbow, further displacement of cover rocks requires secondary breakaway along the frontal flank of the denuded core complex. Branch faulting that transfers the principal surface of slip into 
either core rocks or cover rocks as warping of the detachment surface proceeds is termed incisement or excisement, respectively (G. A. Davis and Lister, 1988). Stepwise migration of the breakaway zone, as incremental isostatic upwarp of core rocks proceeds, is a common form of excisement (Spencer and Reynolds, 1989b).

Although the alternate structural model (Fig. 16B) also accomplishes dramatic uplift of midcrustal rocks by a comparably simple scenario, the resulting intricate distribution of rock masses that could preserve mylonitic fabrics does not match observed field relations. In particular, the mutual isolation and abrupt offset of fault segments that would have the character of mapped mylonitic zones and detachment faults have not been reported. Nor is it clear how reduction of a crustal profile by rotation of tilt-blocks in place could ever place syntectonic volcanosedimentary strata in direct contact with mylonitic core rocks without the wholesale structural elision of crust embodied in the standard detachment model (Fig. 16A). Even so, the alternate model (Fig. 16B) provides important insights, for it elucidates aspects of the behavior of the intricately distended upper crust that forms the upper plate in the detachment model (Fig. 16A).

The detachment model (Fig. 16A) can be applied as follows to the tectonic features of the study area (Figs. 1 and 13): (1) the gently tilted block of the Galiuro Mountains northeast of the San Pedro trough is the area of unextended ground; (2) the structural front of the Galiuro Mountains along the eastern flank of the San Pedro trough is the breakaway zone; (3) the detached synformal downbow lies at depth beneath younger basin fill of the San Pedro trough; (4) the antiformal uplift forms the tectonically denuded Catalina core complex; and (5) the substratum of the Tucson Basin and rock masses of the adjacent Tucson Mountains form the rooted fault block of cover rocks stripped from above the core complex exposed to the northeast. The Catalina detachment fault, which bounds the Catalina core complex on the southwest, is a segment of the detachment surface that also served as a secondary breakaway structure after the San Pedro detachment fault had locked up beneath the San Pedro trough. Local strands of incisement and excisement structures may occur in association with various perched allochthons of cover rocks in Redington Pass.

\section{Kinematics of detachment faults}

Development of a broad core complex by isostatic uplift of tectonically denuded midcrust presumably occurs incrementally as a laterally migrating wave of midcrustal uplift propagates away from the initial breakaway zone (Wernicke and Axen, 1988). The diachronous uplift front is a migratory monoclinal flexure in the detachment surface (Spencer and Reynolds, 1989b, 1991; Bartley and others, 1990). Transient secondary breakaway zones develop in sequence above successive segments of the detachment surface as upbowing proceeds. Greater and greater expanses of distended cover rocks are stranded as tilt-blocks above the expanding portion of the detachment system that has locked up.
Excisement systematically shifts the position of the active detachment surface forward from the initial breakaway zone (Lister and Davis, 1989; Spencer and Reynolds, 1989b).

Ideally, each segment of the initially subhorizontal detachment fault serves temporarily as the root of a listric headwall fault curving upward to steeper dips in a transient breakaway zone near the surface. These steeply dipping faults are then systematically rotated to gentler dips as rolling uplift of the footwall proceeds. Seismicity could be continuously generated along sequentially active breakaway zones formed above successive positions of the migratory monoclinal flexure in the detachment fault. The detachment fault itself would gradually evolve from an aseismic midcrustal feature with gentle dip to a subhorizontal but inactive exposed feature. Provided questions of metamorphic grade can be resolved, a similar final geometry of exposed detachment systems could also be envisioned as the result of flexural bending of footwalls of steep normal faults, such that fault surfaces rotate incrementally to gentle dips as hanging walls continue moving (Buck, 1988).

Recent work has confirmed the diachronous evolution of a typical detachment system in the Buckskin and Rawhide mountains of western Arizona (Spencer and Reynolds, 1989b). Associated strata include two sets of syntectonic sedimentary sequences: (1) older successions containing clasts derived entirely from cover rocks, and (2) younger successions containing clasts derived from core rocks as well. Areal stratigraphic and structural relations indicate that updip segments of the detachment fault had locked up by 14 to $16 \mathrm{Ma}$, whereas downdip segments remained active until 10 to $12 \mathrm{Ma}$. Mylonitic gneiss lying structurally beneath the detachment fault has yielded generally coordinate midMiocene ( $\sim 15 \mathrm{Ma})$ cooling ages (Spencer and others, 1989b). Sliver wedges and tilt-blocks of the cover plate were stranded sequentially above the progressively upwarping detachment surface as mylonitic debris was shed from successive breakaway zones. Syntectonic strata of the Date Creek basin are exposed above the detachment fault in the nearby Artillery Mountains, located downdip from the denuded Buckskin/Rawhide core complex. Systematic up-section decreases in mean dip and increases in the proportion of mylonitic clasts record coupled tilting of cover rocks and exhumation of core rocks during the progress of detachment faulting (Spencer and others, 1989a).

\section{Contrasting rotational mechanisms}

In summary, three distinctly different hypotheses exist for systematic rotation of steep normal faults to gentle dips during evolution of a detachment system: (1) rotation as part of a subparallel array of steep normal faults during bulk tilting of the intervening fault blocks or slices in card-deck, book-stack, or domino-tile fashion; (2) migratory arching of a subhorizontal intracrustal detachment surface in the manner of a rolling wave, which causes each segment of the surface to acquire a transient steep dip before finally assuming a subhorizontal attitude; and (3) flexural bending of the footwall of a steep normal fault, as it is 
unloaded by removal of the hanging wall, to allow the fault surface to curve upward incrementally to gentle dips. In principle, each process might juxtapose displaced cover rocks against mylonitic core rocks provided the faults involved were able to penetrate deep enough into the crust to operate as combined brittle-ductile shear zones. Each suggested process makes different predictions, however, about details of structural geometry, the sequence of development of auxiliary structures, and facies relations of syntectonic sedimentary sequences deposited in different half-graben subbasins whose development is controlled by the extensional regime.

One direct test of inferred fault geometry is afforded by the dihedral angles observed between bedding in syntectonic sedimentary sequences and the planes of detachment faults or other low-angle normal faults into which the displaced sequences dip. These dihedral angles are reliable measures of the dips of faults that first initiated offset of sedimentary successions at the surface, and are most commonly in the range 45 to $60^{\circ}$; either rotational or listric fault geometry is required during transfer of the sedimentary strata from depositional attitudes to tilted positions dipping downward into gently inclined fault surfaces (Hamilton, 1982, 1987). However, either of the alternate patterns of fault behavior that have been suggested for detachment systems (Fig. 16A and B) could account for this observation: (1) listric headwall and splay faults that merge downward with a more gently dipping detachment surface, or (2) faults that were initially steep but rotated to gentle dips as crustal extension continued.

In some regions of severe extensional strain in Nevada, observed dihedral angles between low-angle normal faults and bedding in thick stratigraphic sections, which were flat-lying prior to offset, suggest rotation of normal faults, now subhorizontal, from initial dips near $45^{\circ}$ that extended to an original depth of 8 to 12 km (Gans and Miller, 1983; Proffett, 1984). These relationships focus attention on the fact that rotation of steep normal faults has achieved major uplift of midcrustal rocks in some instances. Where adjacent opposed tilt domains are separated along strike by only a warped hinge zone (Faulds and others, 1988) or scissors-like dip-slip faults (Chamberlin, 1983), rather than by a belt of strike slip, the idea of rotation in place may prove more attractive and more realistic than the concept of detached slabs undergoing lateral translation in opposite directions (Chapin, 1989). Moreover, multiple superimposed arrays of rotational mid-Tertiary normal faults have already been documented for selected areas within the Southwest Border region (Fryxell and others, 1987; Dokka, 1989).

\section{TERTIARY SEDIMENTARY ASSEMBLAGES}

Mid-Tertiary sedimentary sequences deposited during the structural evolution of the Catalina core complex are widely exposed as tilted homoclines along the flank of the San Pedro trough, where the tilted strata lie unconformably beneath erosional remnants of younger basin fill. Less continuous outcrops occur within eroded uplands lying to the southwest. Subdued exposures, largely masked by younger Neogene basin fill, are also present locally along the flank of the Tucson Basin southwest of the Catalina core complex. Conglomeratic facies are prominent and commonly dominant, not only in strongly tilted mid-Tertiary successions of mid-Oligocene to mid-Miocene age but also in gently dipping basin fill of post-mid-Miocene age. The conglomeratic strata were deposited mainly by braided streams flowing on alluvial fans or on compound braidplains formed by coalesced or interfingering fans built into and confined within local structural depressions. Their lithology reflects abrupt local relief during sedimentation, and indicates that all clasts were derived from eroded fault scarps or tilt-blocks that were located within the study area. Progressive stratigraphic onlap of tilt-blocks and residual bedrock hills produced local buttress unconformities showing appreciable depositional relief at selected horizons (Fig. 17). Lateral facies transitions from conglomeratic beds to finer-grained lacustrine strata, which were deposited in low-standing areas of some basin floors, are well preserved both in tilted mid-Tertiary strata and in post-mid-Miocene basin fill (Fig. 18). Pedogenic caliche or calcrete layers occur sparingly. They are closely spaced only in condensed sections reflecting reduced rates of sedimentation at horizons interpreted as laterally equivalent to erosional unconformities.

Homoclinally tilted mid-Tertiary strata display facies trends and structural relations, such as fanning dips, indicative of syntectonic deposition during active faulting, but the largely undeformed post-mid-Miocene beds accumulated during essentially passive aggradation that achieved partial burial of rugged residual topography formed principally by earlier faulting (Lindsay and others, 1990). Subsequent dissection of basin fill has been accompanied by formation of pediment surfaces and stream terraces mantled by varying thicknesses of reworked gravels and displaying soil profiles of varying maturity. Relatively older and higher piedmont surfaces are intricately dissected, whereas younger surfaces standing at lower elevations are accordingly less dissected (Morrison, 1985). Modern floodplain alluvium is present along trunk streams and their major tributaries.

Clast types in conglomeratic strata exposed near a core complex provide an important record of the progress of tectonic denudation and erosional exhumation of nearby core rocks (Miller and John, 1988). Gager (1984) introduced the concept of contrasting intraplate and extraplate strata to distinguish between detached units that are part of the upper plate of a detachment system but were derived from cover rocks and core rocks, respectively. In that sense, all strata offset by fault strands of the main detachment fault system are intraplate strata that contain no mylonitic detritus derived from core rocks. The proportion of mylonitic debris in other successions is governed by the structural position of their sources with respect to both mid-Tertiary and Laramide mylonitic zones.

\section{Overall facies framework}

During accumulation of the varied Tertiary succession, local depositional systems were controlled chiefly by the locations of 


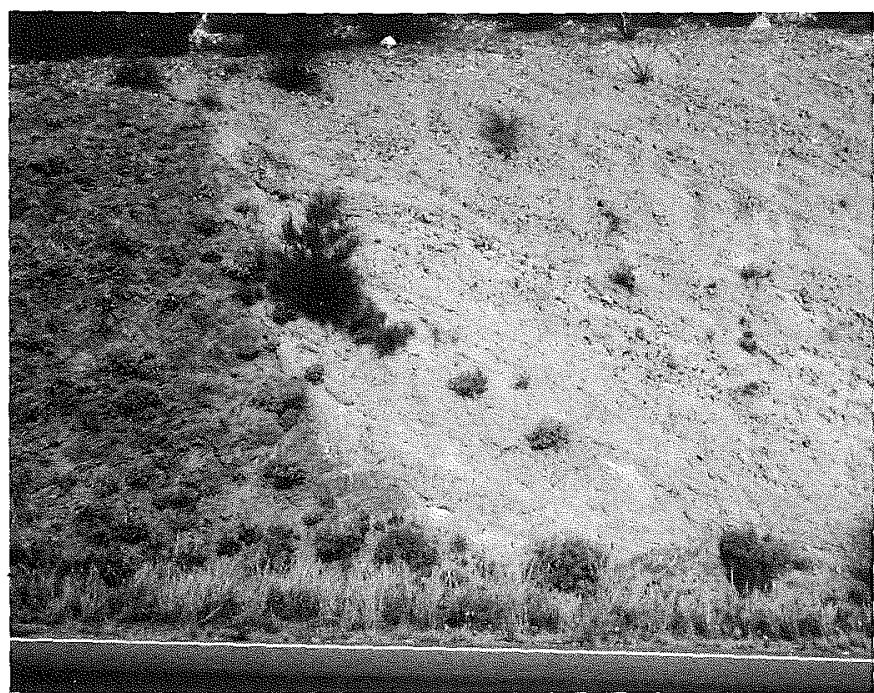

Figure 17. Buttress unconformity of post-mid-Miocene strata in Quiburis Formation (right) overlying Precambrian basement of Oracle/Ruin granite suite (left) along an inclined depositional contact (color contrast) marking an eroded paleofault scarp in Black Hills near Mammoth; stringers of angular rubble derived from subjacent granite reworked into beds near contact (roadcut $\sim 7.5 \mathrm{~m}$ high).

normal faults, which delineated evolving half-graben basins and the associated tilt-blocks that supplied most sediment (Fig. 19). Transverse sediment transport in proximal fan environments was accompanied by oblique or even longitudinal sediment transport in more distal settings. Both proximal and distal fluvial systems graded locally to lacustrine environments produced by structural ponding of paleodrainages.

Fluvial deposits range from coarse conglomerates and sedimentary breccia, deposited as alluvial fans derived from nearby sources of high relief, to conglomeratic sandstone and associated laminated sandstone deposited on finer-grained braidplains in more distal settings. Lacustrine deposits include algal carbonate and gypsiferous evaporite beds as well as claystone with intercalated sandstone beds of several origins. Massive megabreccia bodies produced by debris avalanches and related debris flows occur locally in association with both fluvial and lacustrine strata. Similar facies associations have been reported for analogous syntectonic mid-Tertiary depositional assemblages exposed elsewhere within the intermountain region (Moores, 1968; Grier, 1983; Miller and John, 1988).

Alluvial fans and landslide megabreccias were shed from both scarp slopes and backslopes of fault-controlled tilt-blocks. On balance, paleocurrent patterns suggest that backslope paleodrainages and braidplains were areally more extensive than those fed from scarp slopes during intervals when faults were active along basin margins. This pattern is to be expected for strongly asymmetric half-graben structures (Fig. 19), as confirmed by modern analogues (Mack and Seager, 1990). During aggradational phases when basin-bounding faults were quiescent, basin geometry and facies distributions were more axisymmetrical.

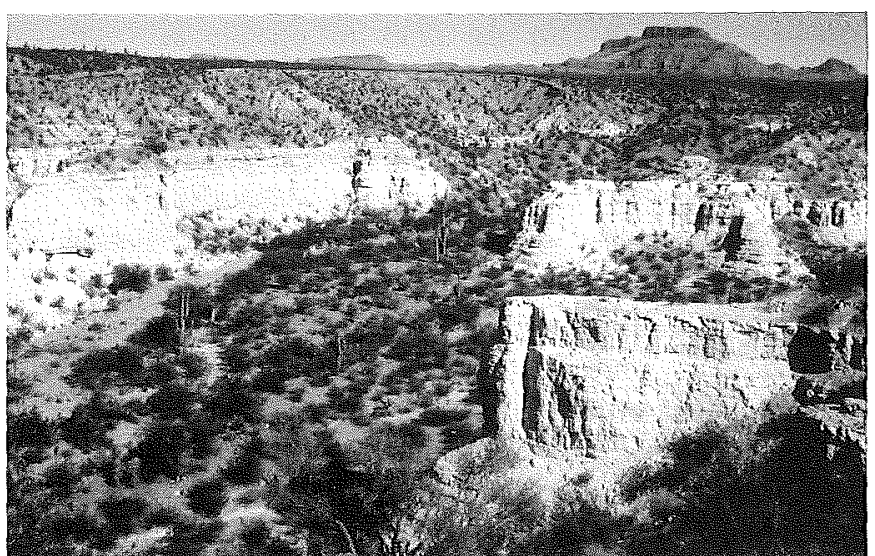

Figure 18. View northeast toward Sombrero Butte along frontal escarpment of Galiuro Mountains showing flat-lying but deeply dissected lacustrine strata (pale hues in foreground) in basin fill of post-mid-Miocene Quiburis Formation deposited along depoaxis of San Pedro trough.

\section{Alluvial fan and braidplain facies}

In the standard notation of Miall $(1977,1978)$, the most voluminous depositional facies observed in both syntectonic deposits and younger basin fill is composed dominantly of massive or crudely bedded gravel $(\mathrm{Gm})$, interpreted as longitudinal bars and lag deposits of anastomosing migratory channel floors traversing alluvial fans or braidplains (Figs. 20 through 22). Further field work conducted in more detail will be required to separate strata that record local depositional features with fan morphology from those that record extensive bajadas or confined braidplains formed by coalescence of multiple fans within structural depres-

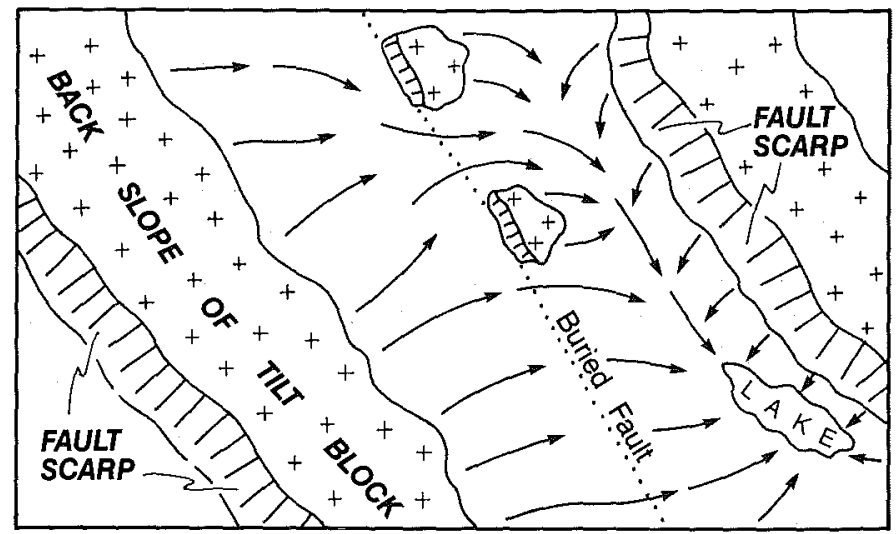

Figure 19. Schematic diagram showing characteristic paleodrainage pattern (arrows) recorded by paleocurrent indicators preserved in conglomeratic syntectonic deposits within half-graben basins bounded by multiple tilted fault blocks; as active faulting wanes, dispersal paths within elongate basins gradually become more axisymmetrical as fans prograde forward from inactive fault scarps. 


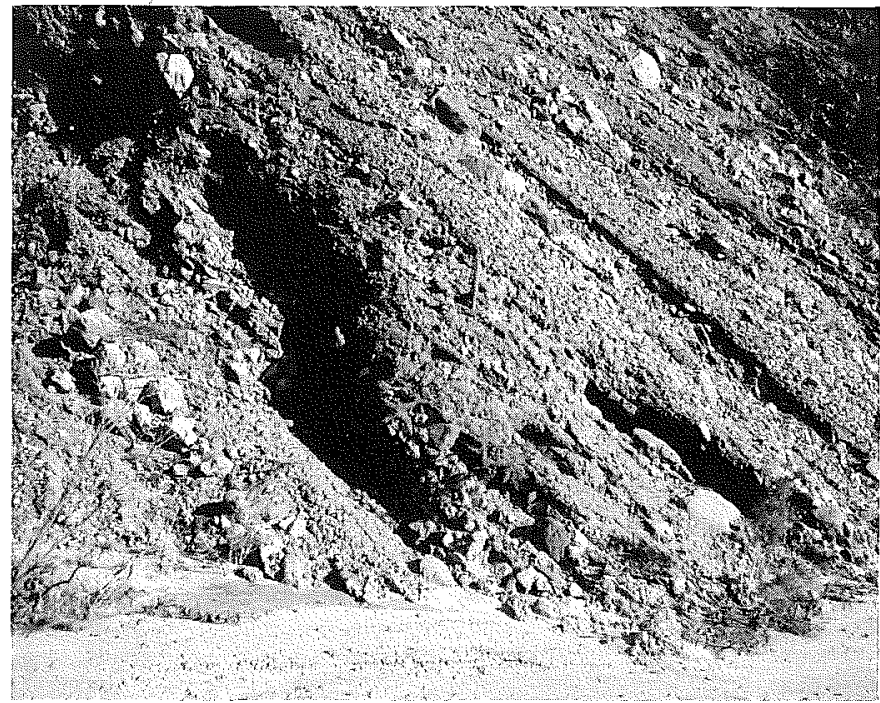

Figure 20. Stream-cut exposure of typical alluvial fan and braidplain facies (upper Oligocene Cloudburst Formation along Camp Grant Wash); note hammer for scale.

sions. Local representatives of the prevalent conglomeratic facies are texturally varied: clasts range from angular to subrounded, maximum clast size ranges from boulders to pebbles, and the degree of sorting varies widely as well. No clear facies distinction can be drawn between clast-supported sandy conglomerate and conglomeratic sandstone in which the only matrix between gravel clasts is sandy sediment lacking silt or clay fractions. The two lithologic types grade freely one to another, even within individual beds. Both seemingly reflect either traction transport as bedload during flood flow or deposition from hyperconcentrated streamfloods (Mack and Rasmussen, 1984; Arguden and Rodolfo, 1986) in paleodrainages with access to varying proportions of gravelly and sandy sediment.

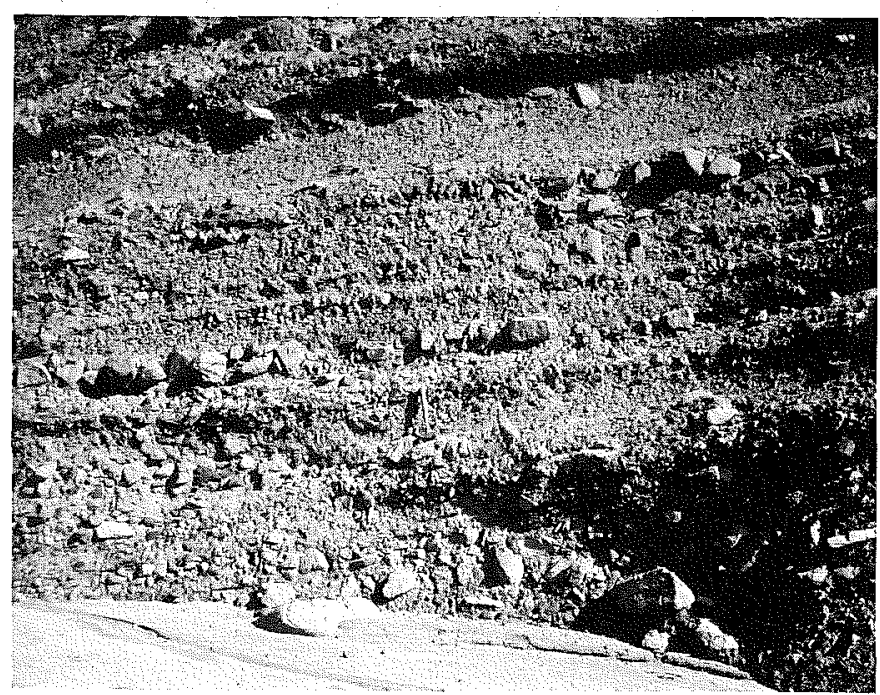

Figure 21. Alluvial fan and braidplain facies displaying unusually angular clasts (lower Miocene San Manuel Formation along Ripsey Wash); note hammer for scale.

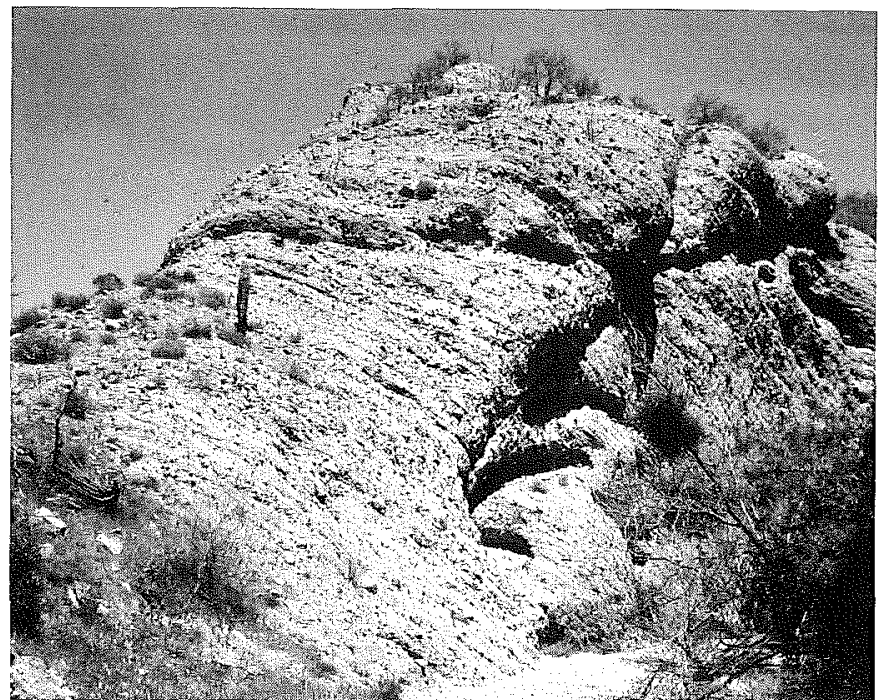

Figure 22. Typical rounded outcrop of heterogeneous alluvial fan and braidplain facies (lower Miocene San Manuel Formation in Corkscrew Canyon between Hackberry and Eagle washes of Tortilla Mountains); hammer in foreground for scale.

Some conglomeratic bedload and streamflood deposits were doubtless confined within broad fan channels, but others may have arisen from sheetflow (Ballance, 1984) or sheetflood (Mack and Rasmussen, 1984) that either spilled over channel walls or spread out as depositional lobes beyond the crossover or intersection point, which marks the distal extent of well-defined fan channels (Nilsen, 1982). Outcrop evidence for channel shapes is rare, but outcrop continuity is generally inadequate to detect the geometry of broad shallow channels with widths commonly observed on aggrading fans and braidplains composed of coarse sediment.

Subordinate associated beds are composed chiefly of: (1) massive matrix-supported debris-flow deposits (Fig. 23), in which gravel clasts are encased within unsorted finer-grained material including silt and clay (Mack and Rasmussen, 1984; Arguden and Rodolfo, 1986); and (2) horizontally laminated sand (Fig. 24), or sand with gravel stringers, deposited in the upper flow regime as successive planar laminae. These subordinate lithologic types vary widely in abundance, but seem locally to represent either parts of channel complexes or more extensive sheets formed by flow events that spilled out of channels and spread widely across fan or braidplain surfaces. Debris-flow deposits are most common within proximal facies where clasts are coarsest, but laminated sandstone is most abundant in more distal facies where the gravel fraction is finer grained. Cross-bedded braided-stream facies (Miall, 1978) are rare, but occur sparingly within both syntectonic and basin-fill assemblages.

Facies analysis of alluvial fan deposits elsewhere has shown that vertical successions commonly display repetitive coarseningupward cycles, from 10 to $20 \mathrm{~m}$ to 100 to $200 \mathrm{~m}$ thick, produced by the progradation of alluvial fans or braidplains into and across floodbasin or lacustrine environments (Steel and Aasheim, 1978; Heward, 1978). Although progradational as well as retrograda- 


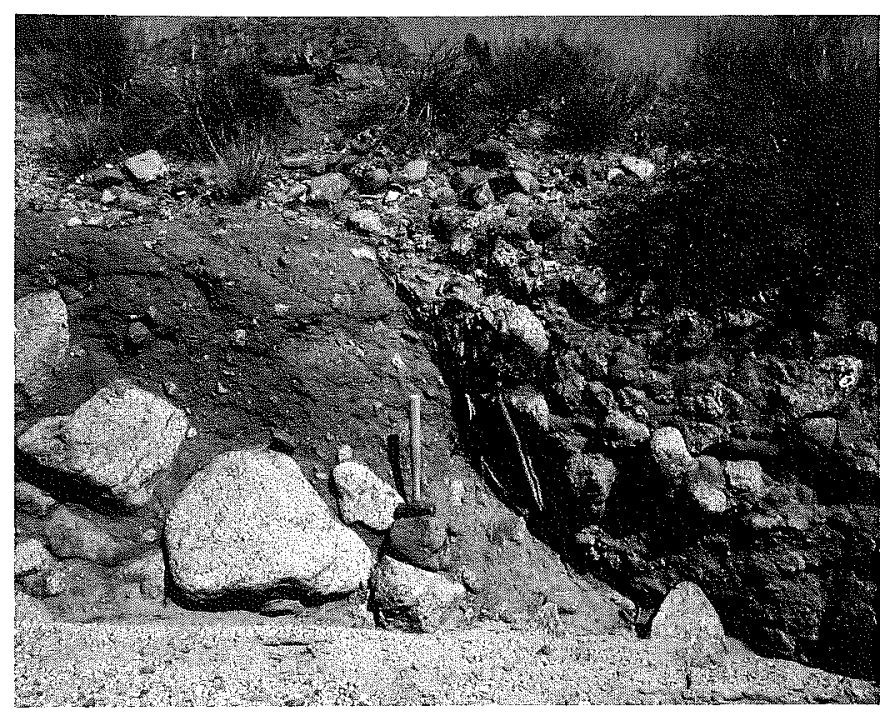

Figure 23. Matrix-supported debris-flow deposit (on left with hammer for scale) overlain along scoured contact (beds dip to right) by clastsupported streamflood deposit in proximal alluvial fan and braidplain facies (upper Oligocene Cloudburst Formation along Cloudburst Wash in Black Hills near Mammoth).

tional facies transitions from fluvial to lacustrine strata are common within the study area, no consistent cyclicity of facies was observed. Absence of prominent cyclicity may reflect rapid subsidence coupled with persistent rejuvenation of relief by syndepositional faulting.

The similarity of the alluvial fan and braidplain facies to gravelly and sandy sediment present along the floors of modern washes and arroyos within the study area suggests that sedimentation occurred under semiarid conditions not greatly different from those of the present (Fig. 25). The unweathered character of

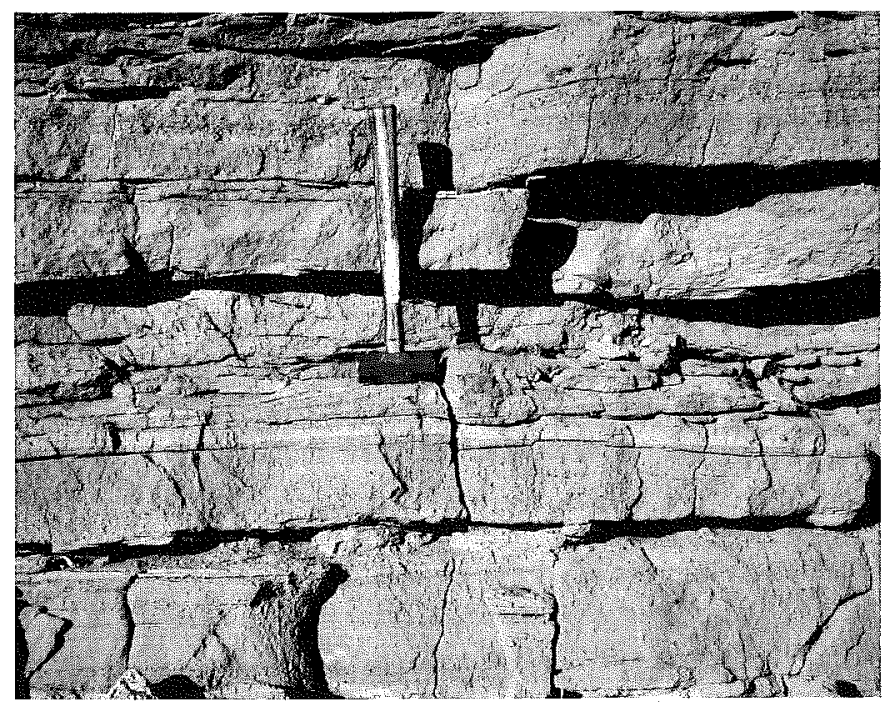

Figure 24. Laminated sandstone in distal alluvial fan and braidplain facies (lower Miocene San Manuel Formation at Cowhead Well near Camp Grant Wash); note hammer for scale.

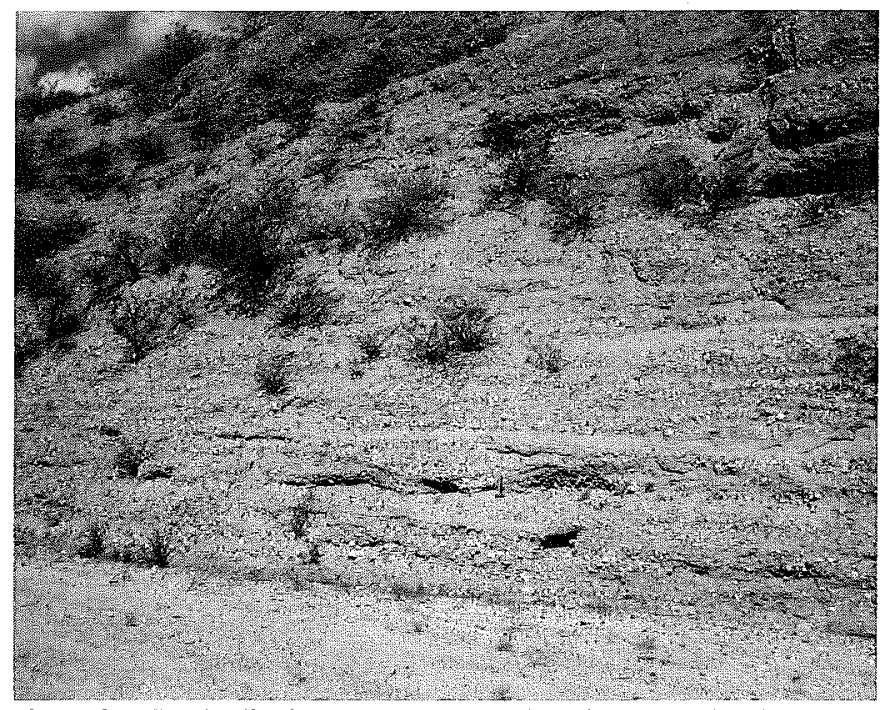

Figure 25. Gently dipping strata of post-mid-Miocene Quiburis Formation (hammer for scale) in cut bank along Teran Wash, and texturally similar loose sediment distributed along modern wash floor (foreground) by current fluvial regime.

limestone clasts in conglomerate and the presence of paleocaliche horizons point to the same conclusion. The analogous sedimentology of many post-mid-Oligocene sequences within the study area forces a cautious approach to all questions of age and correlation. Although differences in induration or color are reliable guides to stratigraphic position in selected contexts, no lithologic criteria are uniformly diagnostic of relative age. In general, the only reliable age assignments and correlations are based on radiometric ages for intercalated tuffs or lavas exposed locally. Over wide areas between dated localities, lateral correlation of strata and distinctions between different intervals of syntectonic strata are dependent on: (1) outcrop continuity adequate to demonstrate stratal equivalence, and (2) structural relations documenting stratal discordance or erosional scour along unconformities present at selected horizons. Local differences in paleocurrent trends and clast assemblages are also helpful criteria for recognition of stratigraphic units and delineation of separate faultbounded subbasins (cf., Hendrix and Ingersoll, 1987).

\section{Interstratified megabreccia bodies}

The most striking lithologic components of syntectonic sequences within the study area are quasitabular lenses and sheets of landslide megabreccia (Longwell, 1951; Burchfiel, 1966) interstratified concordantly within enclosing sedimentary successions (Fig. 26). Megabreccia is most commonly associated with coarse conglomeratic strata of alluvial fan and braidplain facies, but is locally in contact with lacustrine and related facies as well. Megabreccia bodies are composed of unsorted angular blocks and shattered masses of pervasively brecciated and transported bedrock (Fig. 27) separated by a structureless matrix of finely com- 


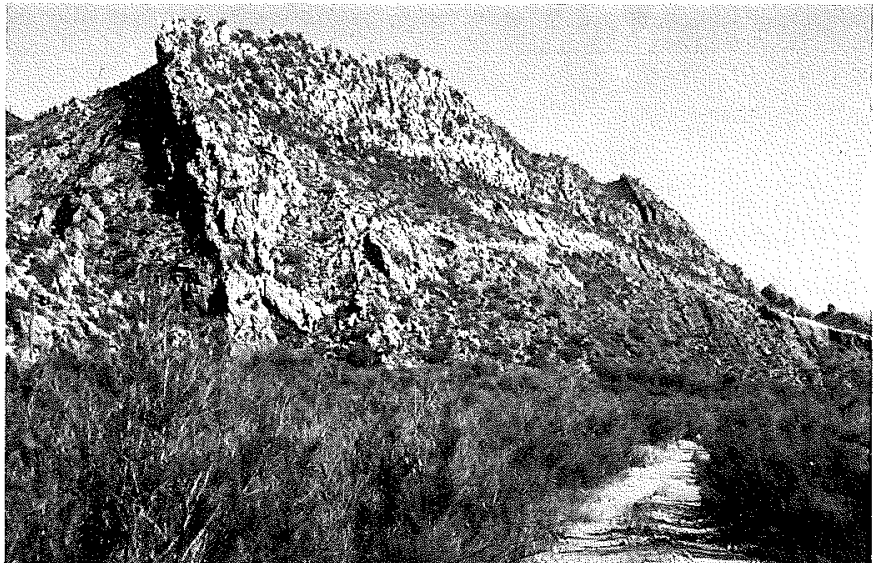

Figure 26. Massive flatiron of lensoid sedimentary megabreccia (pale hue), dipping to right (east) and interstratified within Hackberry Wash facies of Cloudburst Formation near Hackberry Spring in Tortilla Mountains.

minuted debris and rock powder (Krieger, 1977; Cornwall and Krieger, 1978). Most megabreccia bodies are either monolithologic or composed of a limited variety of rock types representing pre-Tertiary formations that are closely associated stratigraphically in the geologic column of the study area. The most characteristic mesoscopic textures are: (1) crackle breccia, a term applied to disrupted rock with outcrop surface that display a tight mosaic of shattered angular fragments of variable size and shape; and (2) jigsaw breccia, in which slightly displaced angular fragments of shattered rock are separated by thin seams of powdery matrix (Yarnold and Lombard, 1989).

Most of the megabreccia bodies were probably emplaced as essentially dry debris avalanches generated by giant rockslides, although some layers within compound megabreccia units may have been emplaced as water-soaked debris flows in which clasts were partly supported by the inherent strength of a slurry-like watery matrix. The mobility of dry debris avalanches has been ascribed variously to: (1) temporary fluidization by entrapped air escaping upward through a mass of moving debris (Kent, 1966), (2) wholesale rafting of a sheet of displaced debris above an ephemeral basal cushion of trapped air (Shreve, 1968), (3) inertial dispersion of particulate debris as a gigantic grain flow by multiple impacts between discrete blocks surrounded by buoyant interstitial rock powder (Hsu, 1975), or (4) similar dispersion of particulate debris through acoustic rarefraction produced by amplified sound waves (Melosh, 1983). All suggested mechanisms of emplacement imply rapid movement for each avalanche or flow. In typical occurrences within the study area, however, stacked units of megabreccia indicate that repeated events built up amalgamated megabreccia bodies derived from diverse parent rocks (Creasey, 1965; Schmidt, 1971; Krieger, 1977).

The sizes of individual clasts in megabreccia range upward to tens of meters in diameter, and internally shattered slabs of broken but grossly coherent parent rock may extend for hundreds of meters in lateral dimension. Amalgamated megabreccia units

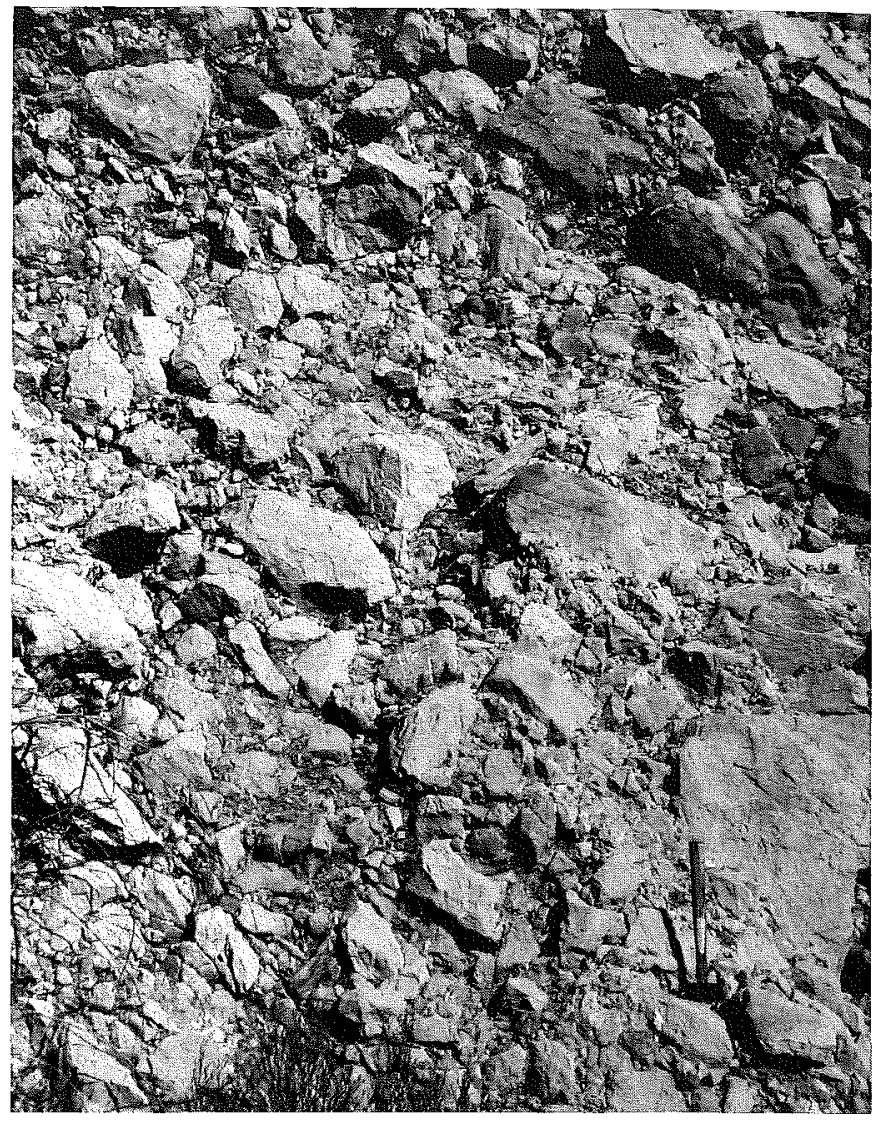

Figure 27. Closeup of limestone megabreccia (Fig. 26) with hammer in lower right for scale; although clasts in field of view are of modest size, giant blocks of internally shattered carbonate rock are also present in contiguous outcrops.

are locally as much as 100 to $250 \mathrm{~m}$ thick and extend for 1 to 5 $\mathrm{km}$ along strike (Creasey, 1965; Krieger, 1977), although discrete depositional units emplaced by single debris avalanches are only 10 to $25 \mathrm{~m}$ thick in most occurrences. Basal contacts are typically smooth and roughly planar, although some scour can be inferred locally and subjacent strata were locally plowed into irregular folds with amplitudes of meters or tens of meters (cf., Yarnold and Lombard, 1989). Clastic dikes derived from underlying sediments or composed of the powdery megabreccia matrix are present in some exposures.

The areal and stratigraphic extent of local megabreccia units suggests origins in two different structural settings (Fig. 28). Amalgamated megabreccia bodies of limited areal extent are commonly associated with paleofaults, along which their apparent overall thickness is great but commonly indeterminate in detail. This type of megabreccia was apparently generated by landslides or rockfalls that occurred on steep fault scarps, and is locally difficult to distinguish in the field from fault breccia formed by tectonic movements along the same fault surfaces. The other type of megabreccia was evidently generated by rockslides along bedding planes tipped to progressively steeper angles on the backslopes of evolving tilt-blocks (Schmidt, 1971). Megabreccias 

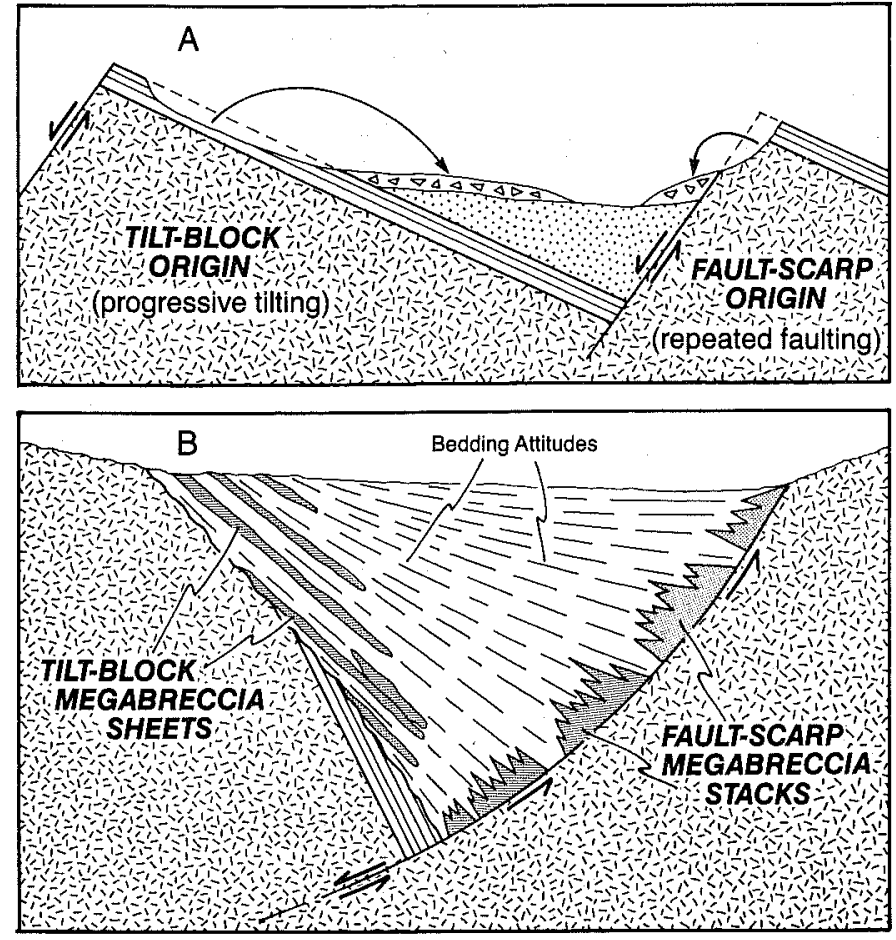

Figure 28. Origins and stratigraphic geometry of megabreccia bodies produced by syntectonic landslides and debris avalanches: $\mathrm{A}$, structural setting and paleotopography at time of formation; B, configuration following additional tilting during subsequent deposition of syntectonic half-graben basin fill.

of this origin form the most extensive sheet-like masses that are intercalated within the sedimentary successions of half-grabens. In some instances, the parent horizons of such large megabreccia bodies were almost completely stripped by rocksliding from the source tilt-blocks (Krieger, 1977).

\section{Lacustrine and related facies}

Varied lacustrine facies (Figs. 29 and 30) deposited in lakes of restricted areal extent intertongue locally with conglomeratic alluvial deposits. Such facies transitions are characteristic in many kinds of continental basins with interior drainage (Hubert and others, 1976; Dunne and Hempton, 1984), and are not diagnostic of structural style. Lacustrine strata form significant proportions of the Mineta, Pantano, and Quiburis Formations (Figs. 1 and 2) but are rare in other units. Individual lacustrine intervals are as thick as 50 to $250 \mathrm{~m}$. Massive gray or green mudstone is the most common lacustrine lithology, but resistant gray algal limestone and bedded white or green gypsum both occur sparingly as distinctive layers or prominent packets of beds. Thin beds of sandstone intercalated with lacustrine mudstone include both traction deposits distributed by wind-driven currents in shallow water and graded turbidites emplaced at deeper levels in quiet water. Closely associated facies include marginal lacustrine sandflat deposits (Hardie and others, 1978; Hubert and Hyde, 1982) laid down in the upper flow regime as sandy aprons where sheetfloods

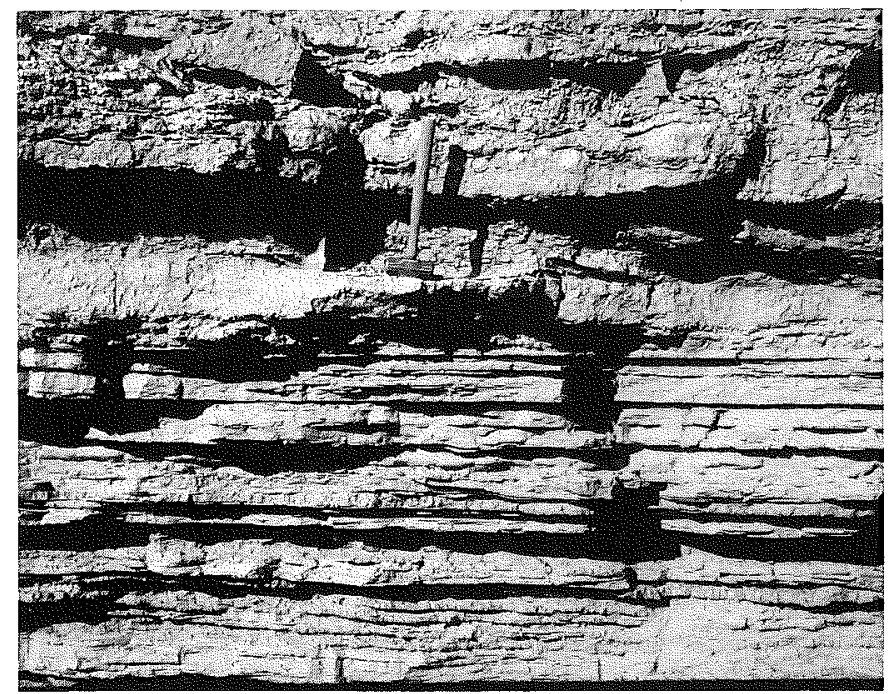

Figure 29. Intercalated limestone (resistant rippled layers) and mudstone in lacustrine facies of post-mid-Miocene Quiburis Formation along Zapata Wash between Mammoth and Aravaipa Creek (hammer for scale).

on the toes of alluvial fans reached lake margins. Thin laminae of siltstone form partings between layers of horizontally laminated sandstone in typical sandflat sequences.

Further field work is required to distinguish between different lacustrine subenvironments that were present. Lake basins in semiarid settings commonly fluctuate from dry phases, during which ephemeral playas or swampy floodbasins occupy the basin floor, to wet phases when perennial lakes are present (Leeder and Gawthorpe, 1987; Lorenz, 1988). Complex stratigraphic relationships develop as lacustrine sedimentation, influenced by marked advance and retreat of lake margins and by linked variations in lake depth, is coupled with progradation and retrograda-

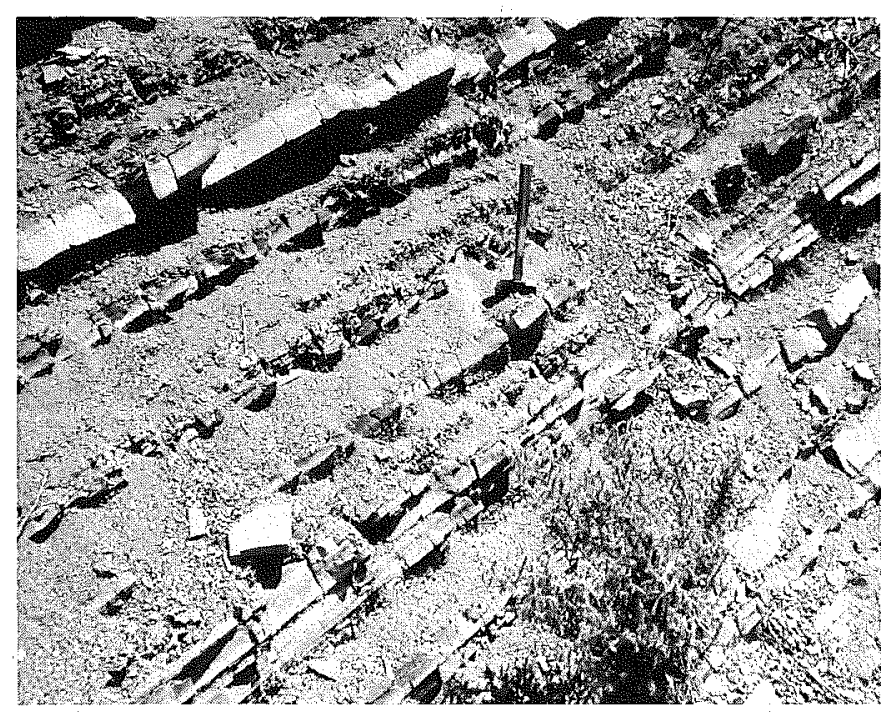

Figure 30. Intercalated dark mudstone and thin laminated sandstone beds (resistant layers) in lacustrine facies of type mid-Oligocene Mineta Formation along Cañada Atravesada (hammer for scale). 
tion of associated alluvial fans. Fan growth was probably controlled by a combination of autocyclic, tectonic, and climatic perturbations. In general, algal carbonate sequences in the study area appear to represent rather local deposition along the shallow margins of perennial lakes of uncertain salinity, whereas gypsiferous beds recording saline conditions appear mostly to represent more widespread playa deposits. Some lacustrine sequences, however, contain offshore micritic limestone beds (Olivares, 1991) or laminated diatomite layers (Shenk, 1990). Thin laminated tuff beds $(1$ to $25 \mathrm{~cm}$ ) that occur sparingly in lacustrine sequences (Scarborough, 1975) represent intermittent ash falls that were redistributed locally by gentle bottom currents.

\section{Half-graben facies associations}

Extensional tectonic domains composed of systems of halfgrabens and tilt-blocks display facies mosaics influenced by backtilting of hanging-wall blocks and abrupt footwall uplift (Leeder and Gawthorpe, 1987). Irregular patterns of subsidence control the thickness and distribution of facies preserved from syntectonic erosion (Fig. 31). Abrupt stratigraphic contrasts develop between sections in different basins or subbasins that are not far apart. Although marine sedimentation is well known in half-graben settings elsewhere (Flint and others, 1986; Leeder and Gawthorpe, 1987), only nonmarine deposits occur within the study area. Because of a consequent lack of evidence for changes in local paleoelevation, the question of whether regional uplift or subsidence was underway during block tilting and mid-Tertiary sedimentation is moot.

The stratigraphic onlap or offlap of facies covering backslopes of tilt-blocks was controlled by the balance between aggradation and erosion within different domains of the system of half-grabens and tilt-blocks. This balance may have been mainly dependent on whether paleodrainages for the half-graben basins were interior or throughgoing, rather than on regional base level or local subsidence rates. Stream captures and other aspects of paleogeomorphic evolution may have contributed to contrasting stratigraphy in adjacent or nearby half-graben basins of the same age and general origin. Episodic events, such as erosion to produce internal unconformities or prolonged stillstand to produce condensed sections, may have been broadly coordinate in their timing within arrays of related half-graben basins, yet limited in extent and diachronous in detail. Diachronous structural development of half-graben basins or subbasins led to inherent stratigraphic anomalies such as stratal overstep to bury the crests of previously eroded tilt-blocks (Fig. 31).

Paleocurrent trends and facies patterns in half-graben basins heavily depend on the extent to which drainage is internal, in which case fluvial transport tends to be mainly lateral toward lakes or playas ponded along the asymmetric keel of the subsiding basin. If drainage is throughgoing, evidence of axial or longitudinal transport is commonly prominent in fluvial facies. The latter situation is apparently prevalent in many half-graben settings associated with incipient continental rifting that initiates growth of

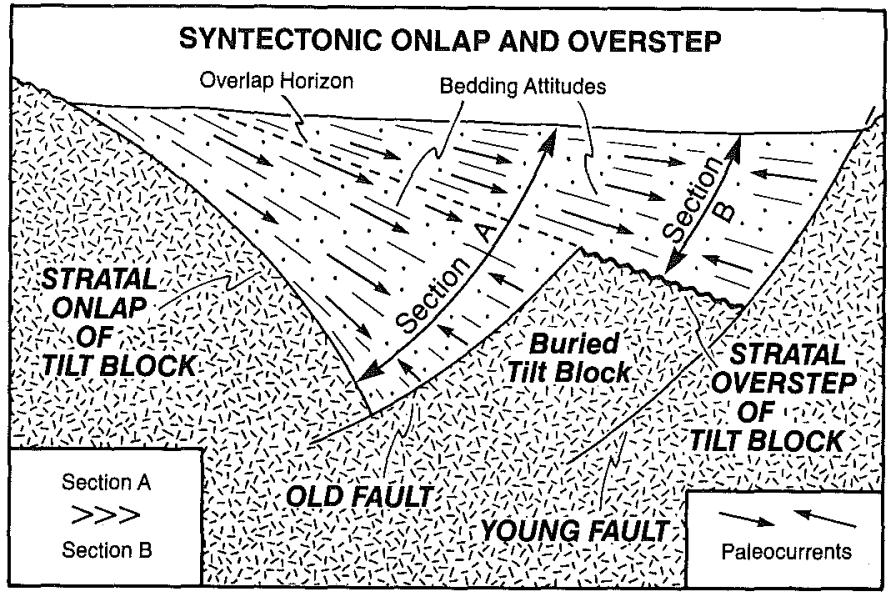

Figure 31. Schematic diagram illustrating typical complex stratigraphic relationships produced by progressive burial of tilted fault blocks during successive episodes of syndepositional faulting that delineate multiple sequential tilt-blocks beneath compound half-graben basins; post-faulting aggradation may eventually allow a more symmetrical paleocurrent pattern to evolve as backtilting of fault blocks ceases and alluvial fans can prograde forward from inactive fault scarps (Mack and Seager, 1990).

oceanic crust (Nadon and Middleton, 1985; Petit and Beauchamp, 1986). In such cases, regional paleogeography favors integration of drainage systems into nearby seaways that flooded parts of half-graben and tilt-block systems, but this opportunity was precluded for the study area and lateral transport was characteristic for most fluvial systems.

\section{Capping basin-fill successions}

Mid-Tertiary syntectonic sedimentation in half-grabens bounded by active growth faults from mid-Oligocene to midMiocene time was succeeded by largely passive aggradation that buried much of the corrugated mid-Tertiary relief by midPliocene time. Post-mid-Miocene strata include basin fill of the San Pedro trough and Tucson Basin, but also veneers and pockets of correlative upland gravel blankets. Accumulation of the latter smoothed local relief over wide areas outside major basins. Although structural activity was relatively quiescent in comparison to the dramatic mid-Tertiary events associated with tectonic denudation of the Catalina core complex, basin-range faulting was underway concurrently, with peak activity in late Miocene time (Menges and McFadden, 1981; Morrison, 1985).

Basin fill retains nearly original depositional dips, contains facies consistent with present valley configurations, and records only mild tectonic deformation except locally near major basinrange faults (Scarborough and Peirce, 1978). Piedmont facies derived from flanking ranges grade laterally to sandy fluvial or lacustrine facies beneath valley centers (Bryan, 1926). This overall facies assemblage is characteristic for Neogene basin fill throughout the Basin and Range province (Groat, 1972; Golia and Stewart, 1984). In typical transects across the San Pedro trough, progradation of piedmont facies over finer-grained basin- 
al facies gave rise to a single clearcut megacycle (Gloppen and Steel, 1981) on the order of 100 to $250 \mathrm{~m}$ thick. This salient progradational cycle is interpreted to reflect onset of relative tectonic quiescence to allow advancing fan toes to bury synrift finergrained facies confined to rapidly subsiding depocenters that served as local sediemnt traps (Blair and Bilodeau, 1988; Mack and Seager, 1990).

Inward dips of unfaulted basin fill along the flanks of the San Pedro trough are most commonly in the range 5 to $10^{\circ}$ but reach 10 to $15^{\circ}$ in some areas. As depositional dips were probably on the order of $5^{\circ}$ or less, present inclinations seem to exceed initial attitudes by perhaps 5 to $10^{\circ}$. Widespread slight tilting of the strata toward the depocentral axis of the San Pedro trough is attributed here to gravitational compaction (Gay, 1989). Thicker and finer-grained strata in the subsurface along the depoaxis underwent more net compaction than progressively thinner and coarser-grained strata overlying buttress unconformities bounding the elongate depocenter on both sides. As a result, greater subsidence of the sediment surface along the depoaxis produced the inward structural tilts observed at exposed horizons.

Modern erosional dissection of basin fill was initiated by integration of the Gila River drainage system (Cooley, 1968) into the head of the Gulf of California during Pliocene time. Prominent Pliocene pediment surfaces are mantled with 1 to $10 \mathrm{~m}$ of alluvial lag gravel that is uniformly coarser grained than underlying basin fill (Morrison, 1985). Subsequent exhumation of buried tilt-blocks occurred at many places along the San Pedro trough, but removal of sediment has been comparatively slight within the Tucson Basin. The stepped degradational topography of dissected basin fill consists mainly of successive pediment levels and correlative strath terraces (Morrison, 1985).

\section{Key paleocurrent indicators}

The most reliable and abundant paleocurrent indicator in the dominantly conglomeratic alluvial deposits of the study area is clast imbrication (Figs. 32 and 33). Cross-bedding is notably lacking in most exposures and is typically confined to small sand lenses where its origin and relationship to the dominant paleoflow direction are uncertain. Parting lineation in laminated sandy layers is rarely observed, but perhaps only because the characteristic style of outcrop weathering does not expose bedding surfaces to view.

The clast imbrication in conglomerate is inferred to reflect the effects of traction on a gravelly substratum during emplacement of longitudinal and other intrachannel bars, and thus to preserve a true record of dominant paleoflow directions. The degree of clast shingling is highly variable from bed to bed and is best developed in relatively well-sorted, clast-supported conglomerate in which the sand matrix is subordinate. As the content of sand becomes greater in conglomeratic sandstone and sandy conglomerate, there is a tendency for nonequant clasts to be disoriented or to lie parallel to bedding. The lack of consistent imbrication in these cases is thought to reflect either: (1) rapid

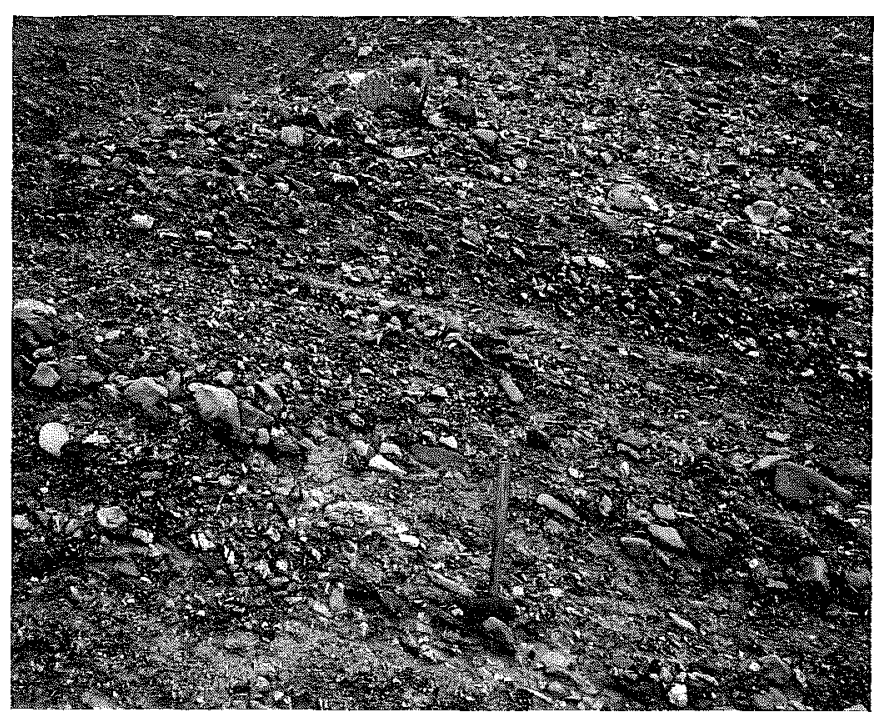

Figure 32. Strong clast imbrication of tabular and platy clasts derived from foliated metasedimentary and metaplutonic rocks in Paige Canyon facies of lower Miocene San Manuel Formation along Paige Canyon in Little (or eastern) Rincon Mountains; gentle stratal dip is downward to right but paleoflow direction is upward to left (hammer in foreground for scale).

sedimentation from hyperconcentrated streamfloods with limited opportunity for imbrication to develop, or (2) joint bedload transport of sand and gravel during which gravel clasts distributed by traction came to rest individually upon a scoured cushion of sand.

Where present, imbrication imparts to conglomerate beds a crude internal foliation with an orientation that can be measured in the field as a strike and dip. If the strike and dip of local bedding is also measured, the initial orientation of the imbrication can be recovered by stereonet rotation about the bedding strike. This methodology achieves consistent results in terms of paleoflow directions inferred for individual homoclines of syntectonic strata, but cannot compensate for possible bulk rotations of homoclines about vertical axes during tectonic offset.

Reconnaissance paleocurrent roses for various local stratigraphic sequences imply that paleoflow directions based on measurements of imbrication typically spanned 60 to 120 degrees of arc within integrated depositional systems. Analogous studies of paleocurrent indicators in fan sediments elsewhere reveal similar dispersion (Mack and Rasmussen, 1984; Hendrix and Ingersoll, 1987), which apparently reflects natural variability in the diverse orientations of channels and thalwegs anastomosing across the surfaces of alluvial fans or braidplains. Vector means for subsets of paleocurrent data showing comparable or lesser dispersion are taken to represent net local paleoflow directions during deposition. On this basis, there are no discernible mismatches between observed clast types and their inferred provenance. Sets of paleocurrent data showing greater dispersion are inferred to represent multiple depositional systems, such as interfingering alluvial fans tapping different sediment sources. 


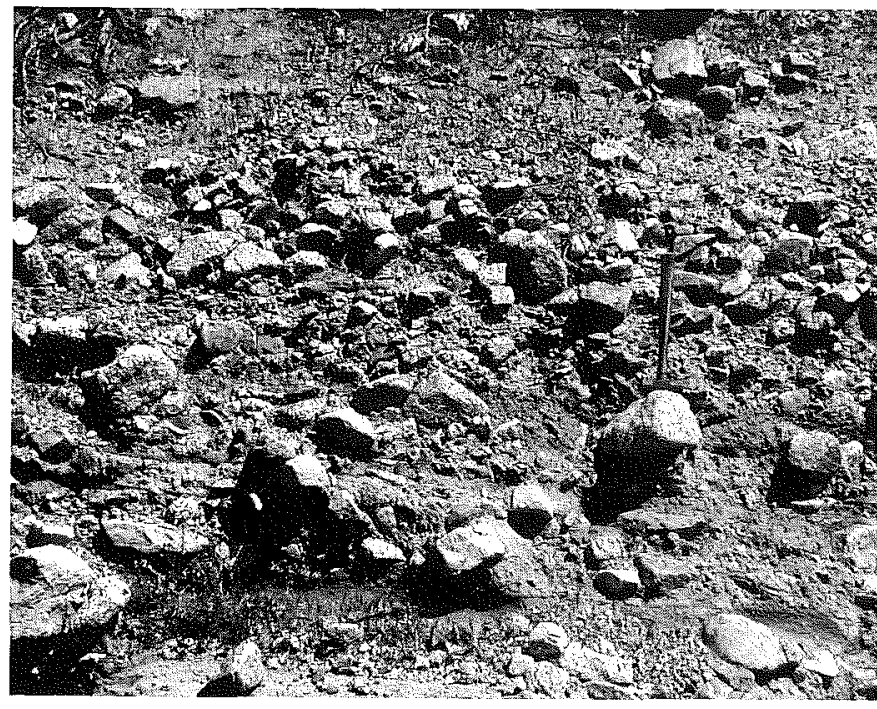

Figure 33. Weak clast imbrication of blocky granitic clasts in lower Miocene San Manuel Formation of Camp Grant Wash; paleoflow direction to right (east); note hammer for scale.

\section{TERTIARY STRATIGRAPHIC FRAMEWORK}

Complex stratigraphic relationships and discontinuous exposure of Tertiary strata within the San Pedro trough, and flanking the Catalina core complex, have led to varied local terminology for correlative units. Figures 1 and 2 indicate the lithostratigraphic nomenclature adopted here, and Figure 34 shows the locations of summary stratigraphic columns (Figs. 35 through 37) indicating its relationship to past usage.

Nearly all the post-mid-Oligocene deposits of local basins and half-grabens were once described as "Gila Conglomerate" (Gilbert, 1875), a term applied initially to all dissected Tertiary valley fill in the upper drainage of the Gila River in both Arizona and New Mexico. Although intended to refer primarily to essentially undeformed basin fill, local usage was extended eventually to include strongly tilted conglomeratic beds as well (Ransome, $1903,1919,1923)$. In this broad usage, the term was comparable in scope to the Santa Fe Group as originally used for all the sedimentary strata of the Rio Grande rift depression (Lucas and Ingersoll, 1981). In northern Sonora, the widespread Baucarit Formation is the analogous Tertiary unit encompassing the varied sedimentary sequences that underlie alluviated basins separating bedrock ranges (Pye, 1959).

Recognition that Tertiary strata of the San Pedro trough include tilted homoclines of steeply dipping beds led to informal subdivision of the Gila Conglomerate (Creasey, 1965) or to elevation of the unit to group status, with constituent formations of different character within the Gila Group (Heindl, 1963). Lack of clearcut criteria for assigning local sequences to the Gila Group or to newly defined older units undercut this approach, and the usage of "Gila Group" was ultimately discontinued by local workers (Krieger and others, 1974).

Two fundamentally different end members of a complex stratigraphic spectrum are present beneath local basins (Heindl, 1958):

(1) Younger units, now termed "basin fill" (Scarborough and Peirce, 1978), are generally compatible in their structural relations with the original concept of "Gila Conglomerate." A1though truncated by pediment surfaces and dissected to varying degrees by modern drainages, these strata commonly display depositional dips and are in contact with bedrock in adjacent ranges along buttress unconformities or steep range-front faults. Their facies patterns were controlled by the morphology of present topographic features, and sedimentary detritus within them is congruent with sediment sources in mountain ranges of the modern landscape.

(2) Complexly faulted and variably tilted older units accumulated in depocenters not coordinate with the morphology of the modern landscape. These older strata are widely preserved beneath younger depocenters but record earlier phases of structural evolution. Sequences that were deposited incrementally during the structural evolution of compound half-graben basins exhibit internal stratigraphic complexity that confounds any simple distinction between older mid-Tertiary strata and younger Neogene basin fill. Interrelations in these instances are gradational between upper and lower tiers of Tertiary strata.

A consistent stratigraphic framework is achieved by mapping a set of four Oligocene-Miocene formations, including local facies and members, throughout the San Pedro trough and the uplands lying to the northeast and southwest in the region north and northeast of the Catalina core complex (Table 7): midOligocene Mineta Formation, upper Oligocene to lowermost Miocene Galiuro Volcanics and Cloudburst Formation, and lower Miocene San Manuel Formation. Correlations and facies relations remain unclear in detail between these units and various subunits of the Oligocene-Miocene Pantano Formation (Table 7) of Cienega Gap and the Tucson Basin. For clarity, the name Pantano Formation is reserved here for mid-Tertiary strata exposed along the southern and southwestern flanks of the Catalina core complex. More gently deformed Miocene-Pliocene strata are designated variously in different modern drainage basins, but are correlative generally with the Quiburis Formation (Table 7) of the San Pedro trough. Unconsolidated gravels of pediments, terraces, and floodplains were deposited during widespread degradation that succeeded accumulation of the Quiburis Formation and its equivalents.

Usage of the term "Big Dome Formation" (Krieger and others, 1974) is not continued here because strata previously assigned to it can be mapped correctly as either San Manuel or Quiburis Formation. In concept, the Big Dome Formation was regarded as an upper Miocene unit younger than the San Manuel Formation of early Miocene age but older than the Quiburis Formation, once thought to be entirely of Pliocene age but now known to be in part of late Miocene age as well. Revised geochronological data indicate that part of the Big Dome Formation, as mapped previously, is composed of lower Miocene strata indistinguishable lithologically from the San Manuel Formation, 


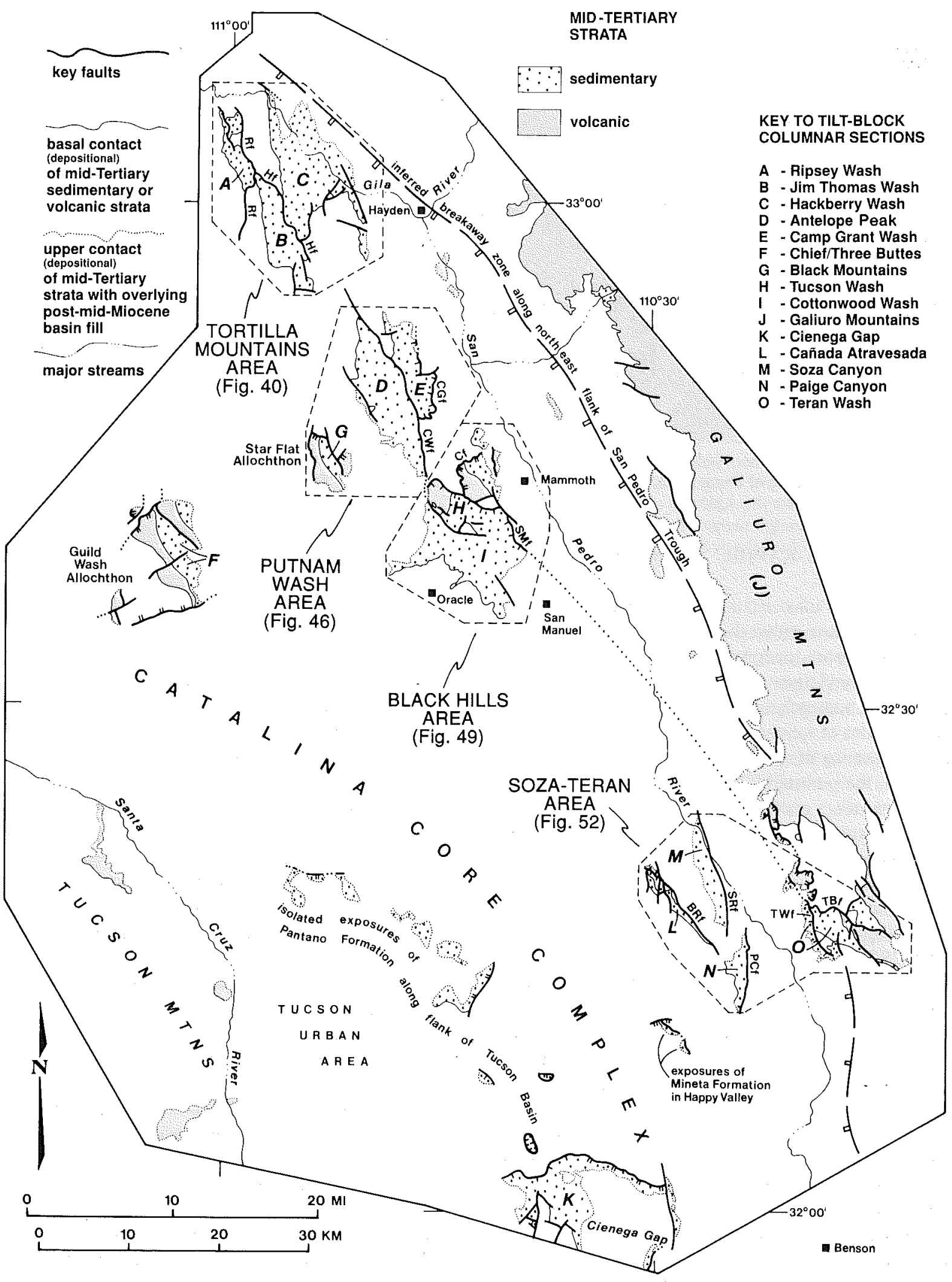

Figure 34. Key to locations of selected stratigraphic columns (Figs. 35-37) and subarea maps (Figs. 40, $46,49,52$ ) within overall study area. Selected faults shown: BRf, Banco Ridge; Cf, Cloudburst; CGf, Camp Grant; CWf, Cowhead Well; Hf, Hackberry; PCf, Paige Canyon; Rf, Ripsey; SMf, San Manuel; SRf, Soza Ranch; TBf, Teran Basin; TWf, Teran Wash. 
whereas the bulk of the Big Dome Formation is laterally contiguous with strata of the Quiburis Formation (Dickinson and Shafiqullah, 1989).

\section{Mid-Tertiary units}

Mid-Tertiary lithostratigraphic units (Table 7) occupy varied structural positions in discontinuous exposures across uplands as well as within lowlands of the study area.
Mineta Formation. Principal exposures of the Mineta Formation lie along the eastern flank of the Rincon Mountains (Fig. 37L) and in the southern foothills of the Galiuro Mountains (Fig. 37O) where preserved thicknesses range from 500 to 1,000 $\mathrm{m}$. Thinner sections of Mineta Formation occur within internally faulted outliers of cover rocks lying structurally above segments of the detachment system where it underlies isolated allochthons. Key outcrops in this structural position are preserved near Red-

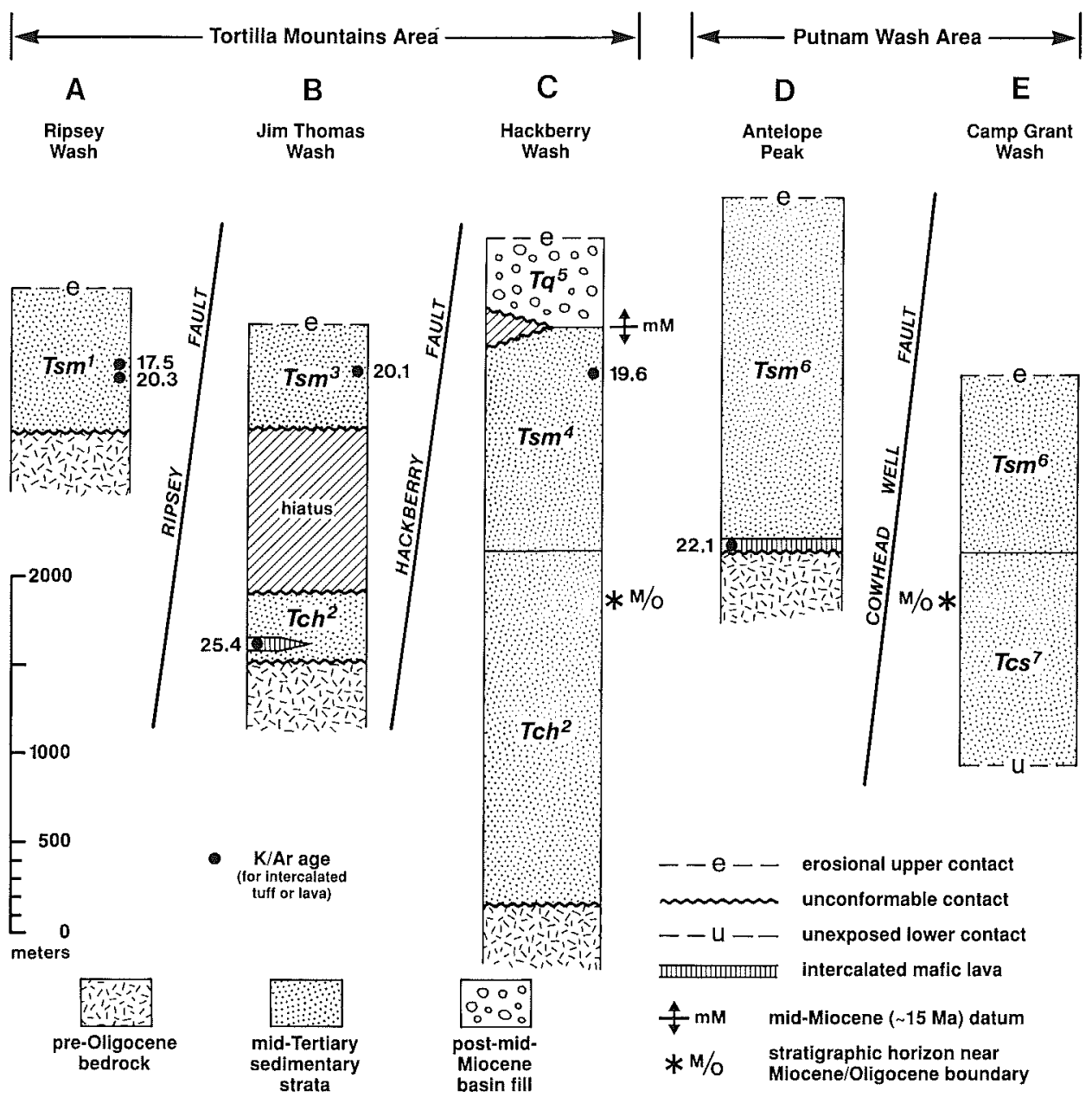

Figure 35. Schematic correlations of post-mid-Oligocene strata of Tortilla Mountains (Fig. 40) and Putnam Wash drainage (Fig. 46) in northern part of study area (see Fig. 34 for locations of columns). Radiometric ages after Dickinson and Shafiqullah (1989). Legend: Tch, Hackberry Wash facies of Cloudburst Formation; Tcs, sedimentary upper member of Cloudburst Formation; Tsm, San Manuel Formation; Tq, Quiburis Formation (overlain locally by younger terrace and pediment gravel cover). Footnotes: 1, "Ripsey Wash sequence" of Schmidt (1971) mapped first as San Manuel Formation by Cornwall and Krieger (1975a, b); 2, main part of "Hackberry Formation" of Schmidt (1971) mapped as lower part of San Manuel Formation by Krieger (1974c) and by Cornwall and Krieger (1975a) but first correlated with Cloudburst Formation by Heindl (1958, p. 168); 3, upper part of "Hackberry Formation" of Schmidt (1971) mapped as upper part of San Manuel Formation by Krieger (1974c) and by Cornwall and Krieger (1975a); 4, includes upper part of "Hackberry Formation" of Schmidt (1971), mapped as upper part of San Manuel Formation by Cornwall and Krieger (1975a), as well as lower part of "Big Dome Formation" of Krieger and others (1974) as mapped by Cornwall and Krieger (1975a) and by Banks and Krieger (1977); 5, main part of "Big Dome Formation" of Krieger and others (1974) as mapped by Cornwall and Krieger (1975a) and by Banks and Krieger (1977); 6, first mapped as San Manuel Formation by Krieger (1974e); 7, mapped as lower part of San Manuel Formation by Krieger (1974e) but lithologically identical to sedimentary upper member of Cloudburst Formation in nearby Black Hills (Figs. 36 and 49). 

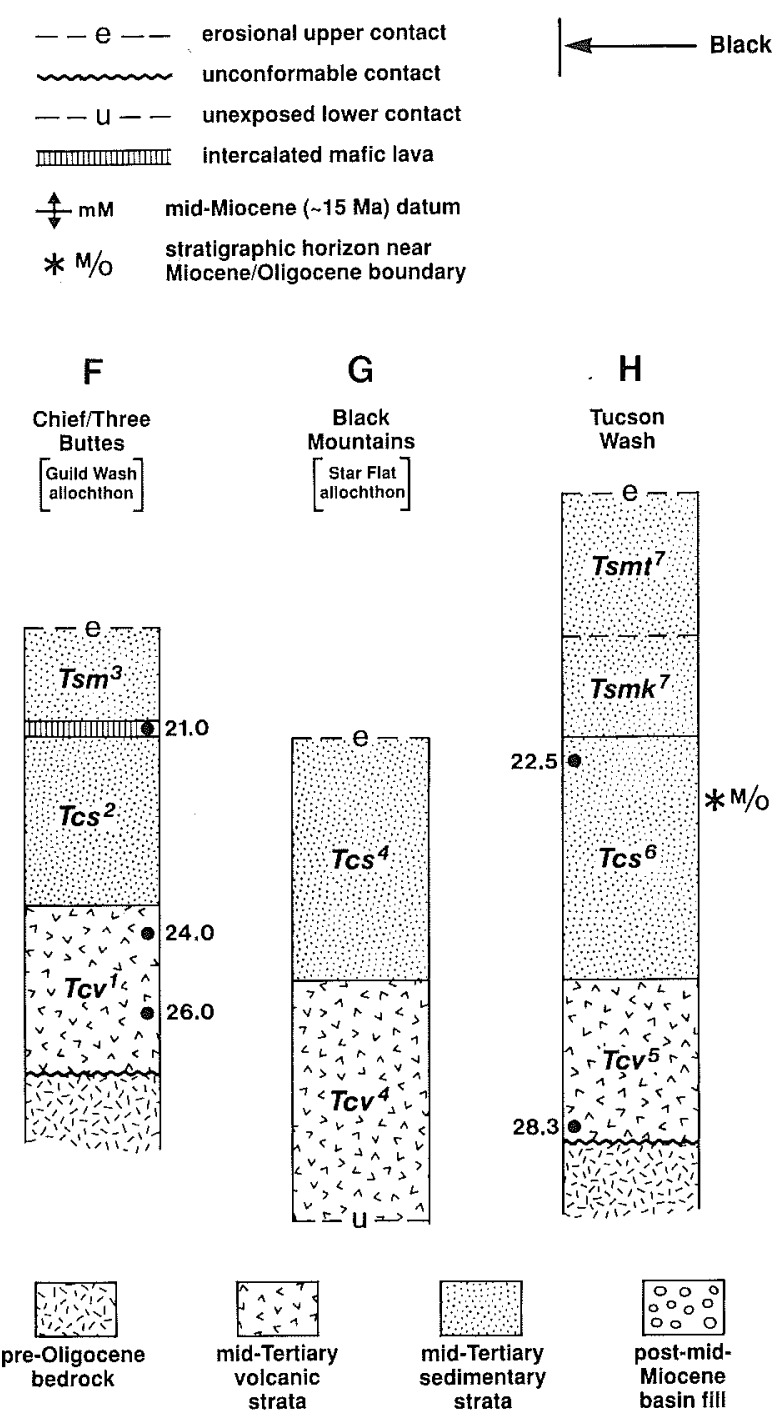

Figure 36. Schematic correlations of post-mid-Oligocene strata of Guild Wash allochthon, Star Flat allochthon (Fig. 46), Black Hills (Fig. 49), and Galiuro Mountains in central part of study area (see Fig. 34 for locations of columns). Radiometric ages after Dickinson and Shafiqullah (1989). Legend: Tw, Whitetail Conglomerate; Tgv, Galiuro Volcanics; Tcv, volcanic lower member of Cloudburst Formation; Tcs, sedimentary upper member of Cloudburst Formation; Tga, Apsey Conglomerate Member of Galiuro Volcanics; Tsm, San Manuel Formation; Tsmk, Kannally Member of San Manuel Formation; Tsmt, Tucson Wash Member of San Manuel Formation; Thh, Hell Hole Conglomerate; Tq, Quiburis Formation (overlain locally by younger terrace and pediment gravel cover). Footnotes: 1, "Tertiary volcanic rocks" of Banks and others (1977) assigned here to volcanic lower member of Cloudburst Formation by analogy with equivalent strata mapped as Cloudburst Formation by Krieger (1974d) at Star Flat (column G); 2, "older Tertiary sedimentary deposits" of Banks and others (1977) formerly referred to correlative Pantano Formation by Barter (1962); 3, "younger Tertiary sedimentary deposits" of Banks and others (1977) formerly referred to correlative Pantano Formation by Barter (1962); 4, first mapped as Cloudburst Formation by Krieger (1974d); 5, "volcanic unit" of Heindl (1963) or "volcanics" of Creasey $(1965,1967)$ in Cloudburst Formation as mapped by Weibel (1981); 6, "fanglomerate unit" of Heindl (1963) or "fanglomerate" of Creasey $(1965,1967)$ in Cloudburst Formation as mapped by Weibel (1981); 7, members of San Manuel Formation of "Gila Group" as mapped locally by Heindl (1963), but regarded jointly by Creasey $(1965,1967)$ as "lower member of Gila Conglomerate," although usage of either "Gila Group" or "Gila Conglomerate" was later abandoned for local usage by Krieger and others (1974); 8, as proposed by Heindl (1963) and discussed by Ladd (1975), but regarded as "upper member of Gila Conglomerate" by Creasey (1965, 1967); 9, as mapped by Krieger (1968b); 10 , complex internal stratigraphy discussed by Creasey and Krieger (1978) and by Creasey and others (1981); 11, as mapped by Krieger (1968b) beneath overlying dated "andesite of Table Mountain" named by Krieger (1968c); 12, as mapped by Simons (1964) and Walsh (1989). 
ington Pass and at Happy Valley between the Rincon and Little Rincon Mountains (Figs. 1 and 2). Both these occurrences have been assigned previously to the Pantano Formation (Drewes, 1974; Thorman and Drewes, 1981), but proximity and lithologic similarity to strata of the type Mineta Formation justify assignment to the latter unit. Drewes (1974) concluded that beds of Mineta Formation at Happy Valley (Fig. 34) unconformably overlap the detachment fault, but close examination of local outcrop relations shows unequivocally that strata of the Mineta Formation are there, as elsewhere, confined entirely to the upper plate of the detachment system. Moreover, no mylonitic clasts from the lower plate of the detachment system occur anywhere within the Mineta Formation.
In key exposures both east and west of the San Pedro River, the Mineta Formation clearly underlies andesitic or latitic lavas of the Galiuro Volcanics (Figs. 37L and O). However, the presence of abundant mid-Tertiary volcaniclastic debris, mixed with varied pre-Tertiary detritus in conglomeratic strata of the Mineta Formation, suggests that the onset of Galiuro volcanism accompanied formation of local fault-bounded basins in which Mineta sediments were deposited. Thorough alteration of a basal ignimbrite in the type locality (Table 7) precludes placing a lower bound on the time of Mineta sedimentation, but estimated rates of sedimentation for analogous successions of syntectonic midTertiary strata imply that deposition probably did not precede mid-Oligocene time $(-30 \mathrm{Ma})$. The discontinuous basal ignim-

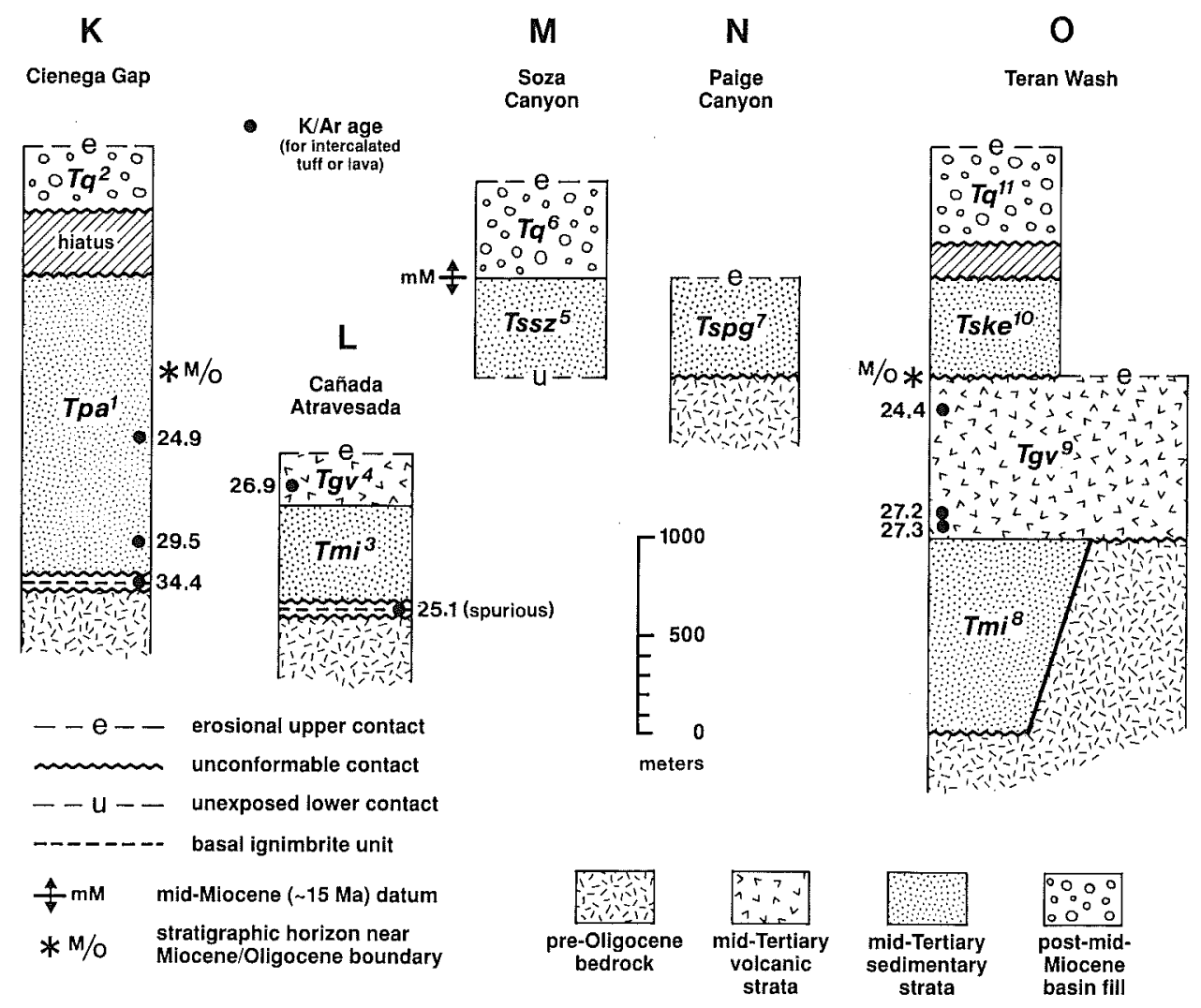

Figure 37. Schematic correlations of post-mid-Oligocene strata of Cienega Gap (Fig. 55), eastern Rincon Mountains (Fig. 52), and southern Galiuro Mountains (Fig. 52) in southern part of study area (see Fig. 34 for locations of columns). Radiometric ages after Dickinson and Shafiqullah (1989). Legend: Tmi, Mineta Formation; Tgv, Galiuro Volcanics; Tpa, Pantano Formation; Tssz, Soza Canyon facies of San Manuel Formation; Tspg, Paige Canyon facies of San Manuel Formation; Tske, Kelsey Canyon facies of San Manuel Formation; Tq, Quiburis Formation (overlain locally by younger terrace and pediment gravel cover). Footnotes: 1 , unit of Brennan $(1957,1962)$ and Finnell $(1970)$ as mapped by Drewes (1977) and Balcer (1984); 2, "Nogales Formation" of Drewes (1977); 3, unit of Chew $(1952,1962)$ and Clay (1970) but referred to correlative Pantano Formation by Thorman and Drewes (1981); 4, as mapped by Dickinson and Olivares (1987); 5, volcanic-clast "Soza beds" of Chew (1952) and Clay (1970); 6, "Banco beds" of Chew (1952) and Clay (1970); 7, metamorphic-clast "Paige gravels" of Lingrey (1982); 8, "Teran beds" of Melton (1965) first mapped as Mineta Formation by Grover $(1982,1984)$ and passing along strike into strata mapped as "Threelinks Conglomerate" by Cooper and Silver (1964); 9, complex internal stratigraphy discussed by Creasey and Krieger (1978) and by Creasey and others (1981); 10, granite-clast "Kelsey beds" of Melton (1965) first correlated with metamorphic-clast "Paige gravels" by Grover (1982); 11, as mapped by Agenbroad (1967) and subsequent workers. 
TABLE 7. TERTIARY STRATIGRAPHIC UNITS OF SAN PEDRO TROUGH AND RELATED DEPOCENTERS*

Nomenclature and Correlations

Quiburis Formation

San Manuel Formation

Cloudburst Formation

Galiuro Volcanics

Mineta Formation

Pantano Formation
Name applied by Heindl (1963) to basin fill of San Pedro trough after ancient Lake Quiburis, which occupied its structural keel from the mouth to The Narrows of San Pedro River.

Included within "Gila Group" by Heindl (1963) and regarded as upper member of "Gila Conglomerate" by Creasey (1965).

Includes "Gila Conglomerate" of Schmidt (1971) and main part of "Big Dome Formation" of Krieger and others (1974) along Gila River, "St. David Formation" of Gray (1967) south of The Narrows of San Pedro River, and "Nogales Formation" of Drewes (1977) in Cienega Gap.

Correlative strata flanking Tucson Basin termed middle and upper "Rillito Formation" by Voelger (1953), "Rillito II" and "Rillito III" beds by Pashley (1966), and "Tinaja beds" by Davidson (1973).

Name applled by Heindl (1963) to exposures in vicinity of San Manuel mine in Black Hills near Mammoth. Included within "Gila Group" by Heindl (1963) and regarded as lower member of "Gila Conglomerate" by Creasey (1965).

Includes "Ripsey Wash sequence" and upper part of "Hackberry Formation" of Schmidt (1971), and lower part of "Big Dome Formation" of Krieger and others (1974).

Name applied by Heindl (1963) and Creasey (1965) to volcanic and sedimentary strata in Black Hills contiguous with exposures along Cloudburst Wash near Mammoth.

Farther west, includes lithologically comparable strata of Star Flat allochthon (Cloudburst Formation of Krieger, 1974d) and Guild Wash allochthon ("Tertiary volcanic rocks" and "older Tertiary sedimentary deposits" of Banks and others, 1977).

Farther north, in Tortilla Mountains, includes main part of "Hackberry Formation" of Schmidt (1971), as inferred by Heindl (1958).

Exposures in Tortilla Mountains and in Putnam Wash previously included in lower part of overlying San Manuel Formation by Krieger $(1974 b, c, e)$ and by Cornwall and Krieger (1975a).

Name applied by Cooper and Silver (1964) to polymodal mid-Tertiary volcanic assemblage of Galiuro Mountains.

Name applied by Chew $(1952,1962)$ to redbeds in homocline exposed along eastern side of Catalina core complex near Mineta Ridge east of Redington Pass; same outcrops later assigned to partly correlative Pantano Formation by Thorman and Drewes (1981).

Exposures east of San Pedro River along Teran Wash and in Teran Basin (Grover, 1982, 1984) pass laterally along strike in Kelsey Canyon into lithologically indistinguishable "Threelinks Conglomerate" of Cooper and Silver (1964).

Name applied by Brennan $(1957,1962)$ to strata in Cienega Gap; usage continued there by Finnell (1970) and Drewes (1977).

Name extended by Davidson (1973), Banks (1976), Drewes (1977), and Anderson (1987) to flanks of Tucson Basin, where includes lower part of "Rillito Formation" of Voelger (1953) and "Rillito I" beds of Pashley (1966).
Lithologic Character

Varied lacustrine and floodplain facies along axis of San Pedro trough grade laterally into and interfinger with alluvial fan and braidplain facies along flanks and at ends of trough.

Gray to buff strata of alluvial fan and braidplain facies with local megabreccia bodies and interstratified silicic tuffs.

Sedimentary strata are dominantly conglomeratic redbeds of alluvial fan and braidplain facies with locally prominent megabreccia bodies, but include massive gray to green lacustrine mudstone at top of formation near Gila River south of Kearny.

Volcanic strata are dominantly andesitic to latitic lavas and breccias, but locally include rhyolitic to rhyodacitic dikes, plugs, domes, and stubby flows.

Andesitic to latitic lavas, rhyodacitic to rhyolitic ignimbrites, and rhyolitic domes, with intercalated volcaniclastic strata

Conglomeratic redbeds of alluvial fan and braidplain facies intertonguing laterally with lacustrine deposits (dark gray to green mudstone and pale gray to white limestone and gypsum), with intervening laminated sandstone and siltstone of marginal-lacustrine sandflat facies.

Varied alluvial fan and braidplain facies, sandflat deposits, lakebeds, and megabreccia bodies.

Andesitic to latitic lava intercalated midway through succession. 
TABLE 7. TERTIARY STRATIGRAPHIC UNITS OF SAN PEDRO TROUGH AND RELATED DEPOCENTERS* (continued)

\begin{tabular}{ll} 
Member and Facies & \multicolumn{1}{c}{ Basal Contact } \\
\hline Multiple informal local subdivisions. & Widely unconformable on variety of older \\
units, but contact with underlying San \\
Manuel Formation is locally a paraconfor- \\
mity with no structural discordance (Scar- \\
borough, 1989).
\end{tabular}

Age Control

Pliocene and basal Pleistocene faunas (Gray, 1967) from "St. David Formation," for which magnetostratigraphy (Johnson and others, 1975) defines age range of early Pliocene to late Pleistocene (although beds younger than Pliocene do not extend into study area).

Late Miocene (Hemphillian) mammalian faunas (Smith, 1967; Lindsay and others, 1984) from San Pedro trough north of The Narrows of San Pedro River (with supportive magnetostratigraphy).

Late Pliocene (2.6 to $3.1 \mathrm{Ma})$ K-Ar ages $(n=$ 3) from ash beds in "St. David Formation" and late Miocene (5.4 to $6.4 \mathrm{Ma}) \mathrm{K}$-Ar ages $(n=4)$ from ash beds in type Quiburis Formation (Scarborough, 1975; Reynolds and others, 1986a).

Tucson Wash (upper) and Kannally (lower) Members (Heindl, 1963) present in Black Hills only.

Locally intertonguing facies of southern San Pedro trough include volcaniclastic Soza Canyon facies, metamorphiclastic Paige Canyon facies, and plutoniclastic Kelsey Canyon facies.

Two conformable and gradational members (Weibel, 1981) occur in Black Hills, Star Flat allochthon, and Guild Wash allochthon: volcanic lower member and sedimentary upper member.

Hackberry Wash facies of Tortilla Mountains composed entirely of sedimentary strata except for local lens of basaltic andesite $(\sim 100 \mathrm{~m}$ thick) only $10 \mathrm{~m}$ above its base.

Complex internal stratigraphy includes Apsey Conglomerate Member near top of formation.

Three conformable and partly interfingering members occur in type area (Chew, 1962; Clay, 1970; Olivares, 1991): upper mudstone member, middle limestone-bearing member, and lower conglomeratic member.

Informal local members of Balcer (1984) revise earlier subdivisions of Finnell (1970) and Drewes (1977).
Rests concordantly, with local scour or minor hiatus, on Cloudburst Formation, or unconformably on pre-mid-Oligocene rocks.

Olivine-bearing basaltic andesite lava occurs along basal contact in Guild Wash allochthon and near Putnam Wash.

Rests unconformably on pre-mid-Oligocene rocks.

Rests locally on partly volcaniclastic strata of Mineta Formation, but elsewhere on preEocene rocks.

Rests unconformably on Laramide erosion surface cut across varied pre-Tertiary rocks.

Lenticular rhyolitic ignimbrite (locally 25 to 50 $\mathrm{m}$ thick) occurs discontinuously along basal contact in type area (Dickinson and Olivares, 1987).

Rests unconformably on varied pre-Tertiary rocks.

Rhyolitic ignimbrite (as much as $15 \mathrm{~m}$ thick) occurs locally along basal contact in type area (Balcer, 1984).
Interstratified silicic tuffs $(n=5)$ have yielded $\operatorname{K-Ar}(n=3)$ and F-T $(n=3)$ ages of 18 to $20 \mathrm{Ma}$ (or 16 to $21 \mathrm{Ma}$ including analytical uncertainties).

Basal lavas have yielded K-Ar ages $(n=2)$ of 21 to $22 \pm 0.5 \mathrm{Ma}$.

Multiple ( $n=5$ ) K-Ar ages for volcanic lower member in Black Hills and Guild Wash allochthon range 25 to $29 \mathrm{Ma}$.

Olivine-bearing basaltic andesite lava near base of Hackberry Wash facies in Jim Thomas Wash yields K-Ar age of $25.4 \pm$ $0.6 \mathrm{Ma}$.

Rhyolite clast in local tuff-breccia intercalated within uppermost $25 \mathrm{~m}$ of sedimentary upper member in Black Hills yields $\mathrm{K}$-Ar age (sanidine) of $22.5 \pm 0.5 \mathrm{Ma}$.

Multiple $(n=12$ ) K-Ar ages range 24 to 29 $\mathrm{Ma}$, except that andesite of Table Mountain overlying Apsey Conglomerate Member yields K-Ar age of $22.8 \pm 0.5 \mathrm{Ma}$.

Overlain concordantly near Mineta Ridge and in Teran area by $27 \mathrm{Ma}$ (K-Ar) andesitic to latitic lavas of Galiuro Volcanics.

Sparse mammalian bones and trackways are consistent with mid-Oligocene age (Scarborough, 1989).

Basal ignimbrite yielded spurious K-Ar age $(\sim 25 \mathrm{Ma})$, but is probably correlative with 34 to $35 \mathrm{Ma}(\mathrm{K}-\mathrm{Ar})$ ignimbrite underlying Pantano Formation.

Lava near middle of sequence yields $\mathrm{K}-\mathrm{Ar}$ age (whole-rock) of $24.9 \pm 2.6 \mathrm{Ma}$.

Basal ignimbrite yields K-Ar age (biotite) of $34.4 \pm 0.8 \mathrm{Ma}$. 
brite may represent the same episode of volcanism recorded by the lower Oligocene $(\sim 35 \mathrm{Ma})$ ignimbrite sheet beneath the Pantano Formation, but the time lag between emplacement of the ignimbrite and the onset of Mineta sedimentation is unknown.

Galiuro Volcanics. Principal exposures of the Galiuro Volcanics occupy a linear belt of perhaps $750 \mathrm{~km}^{2}$ in contiguous highlands of the Galiuro Mountains and associated uplands lying east of the San Pedro River. Isolated outcrops along the San Pedro trough occur as exposed crests of tilt-blocks exhumed by dissection of basin fill near the San Pedro River (Figs. 1 and 2). Some volcanic subunits of the tilt-block exposures can be correlated with specific members of the type Galiuro Volcanics exposed in the mountains to the east (Krieger, 1968c, e). The breakaway zone along the Galiuro range front (Fig. 13) separates the belt of strongly tilted volcanics near the San Pedro River from the more gently dipping strata within the range itself.

At Aravaipa Creek, a thin sequence of volcaniclastic strata lying conformably beneath the main volcanic pile has been termed "Whitetail Conglomerate" (Fig. 36J), and by inference correlated with a sedimentary unit widely exposed outside the study area in the region north of the Gila River. Single early Oligocene ( 33 to $34 \mathrm{Ma}$ ) K-Ar ages from each occurrence support the correlation (Dickinson and Shafiqullah, 1989). The relationship of this local volcaniclastic sequence to the Mineta Formation exposed farther south is presently unknown. Much of the type Whitetail Conglomerate in the region north of the Gila River (Creasey and others, 1983) is probably laterally equivalent to parts of the Cloudburst and San Manuel Formations in the Tortilla Mountains, which lie immediately south of the Gila River within the northern part of the study area (Figs. 1 and 2).

Cloudburst Formation. Prior to the acquisition of radiometric dates that bracket its age betwen late Oligocene (28 to 29 $\mathrm{Ma}$ ) and early Miocene (22 to $23 \mathrm{Ma}$ ), the Cloudburst Formation was regarded as Laramide in age (Dickinson and Shafiqullah, 1989). In its type area, the unit rests depositionally on both Precambrian basement and Laramide porphyry (Weibel, 1981).

The type Cloudburst Formation of the Black Hills (Fig. $36 \mathrm{H})$ includes a volcanic lower member $(\sim 800 \mathrm{~m})$ and a sedimentary upper member $(\sim 1,200 \mathrm{~m})$. Heindl (1963) described the two members in stratigraphic order as the volcanic and fanglomerate "units," respectively, but Creasey $(1965,1967)$ concluded that complex intertonguing relationships preclude their recognition as mappable stratigraphic members. Although the intraformational contact between the two members is gradational and locally interfingering, subsequent areal mapping has shown that they can be successfully distinguished as separate stratigraphic units (Weibel, 1981). The contact is placed at the horizon above which lavas and volcanogenic breccias are absent, although lenses of sedimentary breccia and conglomerate are locally intercalated within the dominantly volcanogenic section beneath the contact.

Both the volcanic lower member and the sedimentary upper member of the Cloudburst Formation are exposed within the Star Flat allochthon (Fig. 36G) along the eastern flank of the Black Mountains 10 to $15 \mathrm{~km}$ west of the type locality in the Black
Hills. Although the lithology of the unit as exposed at Star Flat is essentially unchanged from the type area (Krieger, 1974d), the volcanic lower member is thicker $(\sim 1200 \mathrm{~m})$ even though its base is unexposed. Analogous but thinner strata of the Guild Wash allochthon (Fig. 36F) north of the Tortolita Mountains are also correlative with the two members of the Cloudburst Formation. Available K-Ar ages confirm their equivalence (Dickinson and Shafiqullah, 1989), and their lithology is generally indistinguishable from Cloudburst strata exposed farther east, although each member is only about $500 \mathrm{~m}$ thick within the Guild Wash allochthon.

Lavas and breccias in the volcanic lower member of the Cloudburst Formation are lithologically similar to counterparts in the Galiuro Volcanics exposed farther east, and the late Oligocene (24 to $29 \mathrm{Ma}$ ) eruptions that produced the two volcanogenic successions were contemporaneous (Table 7). Further work may establish detailed correlations between specific volcanic units within the two formations. For now, separate stratigraphic names are retained for the two sequences because the lavas and breccias of the Galiuro Volcanics are intercalated with and overlain by extensive sheets of ash-flow and air-fall tuff, whereas the volcanic lower member of the Cloudburst Formation generally lacks interstratified tuff and is overlain gradationally by thick conglomeratic beds forming the sedimentary upper member. The volcaniclastic Apsey Conglomerate Member ( $125 \mathrm{~m}$ thick) of the Galiuro Volcanics (Fig. 36J) apparently represents a thin temporal equivalent of some part of the sedimentary upper member of the Cloudburst Formation.

The Hackberry Wash facies of the Cloudburst Formation in the Tortilla Mountains (Figs. 35B and C) was informally termed "Hackberry Formation" by Schmidt (1971), and has been included within the overlying San Manuel Formation by subsequent workers. It is treated here as a northern facies of the Cloudburst Formation because of the consistently brownish to reddish coloration of its conglomeratic strata, which are lithologically dissimilar to the gray or buff beds of the overlying San Manuel Formation, and because of its general age equivalence to the type Cloudburst Formation (Table 7).

Cloudburst/San Manuel contact. Exposed contacts between sedimentary sequences of the Cloudburst and San Manuel Formations are typically concordant (Figs. 35C, E, and 36H), although minor erosional scour is evident locally. The contact is placed above the highest redbeds (Cloudburst) underlying gray to buff strata (San Manuel). Where the two units form parts of the same homoclines, the mean dip of Cloudburst strata is consistently greater than the mean dip of overlying San Manuel beds. This observation implies syntectonic deposition as progressive tilt carried deeper horizons of half-graben basins to steeper dips while sedimentation continued. The formational contact is locally unconformable, displaying mappable angularity (Fig. 35B). Over wide areas, strata of the San Manuel Formation rest directly on pre-Oligocene rocks (Figs. 35A through D, and 36I).

Cloudburst strata evidently were preserved only within downdropped grabens or half-grabens where they were protected 
from erosion as complex fault blocks evolved. Within such basins, continuation or resumption of sedimentation produced essentially conformable contacts with the overlying San Manuel Formation. Elsewhere, correlative San Manuel horizons overlapped deformed and truncated Cloudburst strata, and overstepped the latter to rest on pre-Tertiary rocks forming parts of eroded horsts or tilt-blocks. Where the Cloudburst Formation is absent, the base of the San Manuel Formation is marked by buttress unconformities that were formed as erosion wore down uplifted areas while sediment buildup continued in adjacent basins.

The red-brown coloration of the Cloudburst Formation is a diagenetic feature whose origin is not well understood. Untinted beds of the overlying San Manuel Formation are commonly similar lithologically except for their paler hue. The alluvial fan and braidplain facies is dominant in both units. Full continuity of sedimentation is precluded, however, by the presence of erosional scour, local paleosols, and discrete lenses of lacustrine strata along the contact between the two formations. These stratigraphic features suggest either a hiatus in deposition or significant condensation of section between major phases of sedimentation.

Available data are inadequate to establish the extent to which the contact between redbeds of the Cloudburst Formation and overlying strata of the San Manuel Formation may be diachronous. The stratigraphic positions of lavas and tuffs that have yielded radiometric ages constrain all exposed contacts to some restricted interval of early Miocene time (20 to $22 \mathrm{Ma}$ ). Near Putnam Wash (Fig. 35D) and within the Guild Wash allochthon (Fig. 36F), olivine-bearing mafic lavas (21 to $22 \mathrm{Ma}$ ) occur at or near the base of the San Manuel Formation (Table 7). These volcanic marker units bear close lithologic resemblance to the olivine-bearing andesite of Table Mountain (23 Ma) exposed farther east at the top of the Galiuro Volcanics (above the Apsey Conglomerate Member) in the Galiuro Mountains (Fig. 36J). The nearly synchronous eruption of olivine-rich lavas, described as both basalt and andesite by different previous workers, may have marked a diagnostic petrogenetic stage in the structural history of the study area. The limits of analytical error for dated rocks from the three occurrences almost overlap at $22 \mathrm{Ma}$, the age assigned here to the base of the San Manuel Formation.

San Manuel Formation. Widespread mid-Tertiary strata of alluvial fan and braidplain facies exposed along the San Pedro trough are correlated with the San Manuel Formation of the Black Hills (Figs. 36H and I) on the basis of lithology and stratigraphic position. Preserved thicknesses range from 500 to 2,000 m. Similar strata occupying the same stratigraphic position in the Guild Wash allochthon are also assigned to the San Manuel Formation (Fig. 36F). Three distinct local facies bearing different clast assemblages are present in the southern San Pedro trough (Figs. 37M through O). In the northern San Pedro trough (Figs. $35 \mathrm{~A}$ through $\mathrm{E}$ ), granitic detritus is uniformly dominant. Radiometric ages (Table 7) indicate that San Manuel deposition spanned an interval of at least $5 \mathrm{~m} . \mathrm{y}$. (22 to 16 ? Ma) during early (and middle?) Miocene time, but did not continue past some ill-defined mid-Miocene horizon (Dickinson and Shafiqullah, 1989).

Pantano Formation. In Cienega Gap (Fig. 34), approximately $1,500 \mathrm{~m}$ of tilted mid-Tertiary strata in the complexly faulted Pantano Formation (Fig. 37K) are exposed structurally above the Catalina detachment fault. The exposures underlie intricately dissected gravel cover of gently dipping Neogene beds. As the contact between Pantano sedimentary strata and an underlying lenticular ignimbrite is apparently unconformable (Balcer, 1984), the time of onset of Pantano sedimentation is not well constrained. Deposition evidently spanned much or all of the interval between mid-Oligocene and mid-Miocene time (Table 7). Parts of the unit are thus probably equivalent in age to Mineta, Cloudburst, and San Manuel strata of the San Pedro trough. Detailed correlations with those units should be sought by future work, for improved correlations might set tighter constraints on inferred offsets across the Catalina detachment system.

Scattered exposures of Pantano Formation underlie dissected pediments along the northeastern edge of the Tucson Basin at the foot of the Santa Catalina and Rincon Mountains. These variably faulted and tilted beds form part of the plate of cover rocks lying structurally above the Catalina detachment fault, but contain no detritus derived from mylonitic core rocks of the lower plate below the detachment fault. Their clast content contrasts strongly with younger units of basin fill rich in mylonitic clasts. The Pantano Formation is apparently also present at depth beneath the depocenter of the Tucson Basin as subsurface "Unit I" of Eberly and Stanley (1978), who reported 1,440 m of redbeds resting on basement and topped by latest Oligocene $(\sim 24$ $\mathrm{Ma}$ ) volcanic rocks in a deep exploratory well (Dickinson and Shafiqullah, 1989).

The lack of mylonitic clasts in the Pantano Formation of Cienega Gap and the Tucson Basin is a striking feature, given the extent and rugged relief of mylonitic gneiss exposures along the steep fronts of the adjacent mountain ranges within the Catalina core complex. Despite the current proximity of these seemingly obvious sediment sources, a representative conglomerate well exposed in a roadcut at the intersection of Soldier Trail and Tanque Verde Road near Tanque Verde Creek just east of Tucson contains the following clast assemblage: unfoliated granite derived from the middle Proterozoic Oracle/Ruin granite suite, 50 percent; mid-Tertiary and Laramide volcanic rocks, 25 percent; sedimentary and metasedimentary rocks derived from Paleozoic and Mesozoic sequences, 25 percent (Voelger, 1953). Historically, the incompatibility of this clast assemblage with the existing basin configuration was a powerful argument for the concept of major tectonic denudation of the Catalina core complex during midTertiary time.

\section{Basin-fill units}

Neogene basin fill includes the Quiburis Formation (Table 7) of the San Pedro trough (Figs. 35C, 36I, and 37), and correla- 
tive strata within other depocenters. Neogene deposits generally equivalent in age and stratigraphic position to the Quiburis Formation also occur widely throughout the study area beneath sedimented uplands lying between bedrock ranges (Figs. 1 and 2). Surficial Quaternary deposits cap older Tertiary horizons in undissected areas of basin floors and broad pediments.

Quiburis Formation. Coarse piedmont facies prograded over finer-grained axial facies as aggradation of basin fill proceeded during Quiburis deposition (Heindl, 1963; Agenbroad, 1967). Clast types in conglomeratic strata consistently reflect sources in adjacent bedrock ranges bordering the San Pedro trough. Well logs indicate a maximum thickness of approximately $500 \mathrm{~m}$ of Quiburis strata along the depoaxis of the San Pedro trough (Heindl, 1963; Agenbroad, 1967). Exposures once mapped as undivided "Gila Conglomerate" (Krieger, 1968b, $1968 \mathrm{c}, 1968 \mathrm{e}$ ) were later specifically redesignated as Quiburis Formation (Krieger and others, 1974). In this Special Paper, basin fill of the San Pedro trough assigned by previous workers to the "St. David Formation" of Gray $(1965,1967)$ in exposures south of The Narrows on the San Pedro River is regarded as part of the Quiburis Formation. To date, however, only Pliocene and younger fossils are known from the "St. David Formation," whereas only Miocene fossils are known from exposures of the Quiburis Formation north of The Narrows.

Quiburis sedimentation buried corrugated paleotopography of tilt-blocks and intervening half-grabens, but erosion has locally removed thinner parts of the basin fill to exhume the crests of once completely buried tilt-blocks. Their flanks are delimited now by buttress unconformities where Quiburis strata are banked against and onlap old erosion surfaces, and their crests project above the exposed level of dissected basin fill. In excellent exposures near Zapata Wash north of Aravaipa Creek (Figs. 1 and 2), a basal buttress unconformity onlapped by Quiburis lakebeds is overlain directly by $5 \mathrm{~m}$ of buried talus breccia derived from Galiuro Volcanics of the underlying tilt-block.

The age of the oldest Quiburis strata in the subsurface is unknown. From the fact that tuffs in the underlying San Manuel Formation have yielded early Miocene ages, the Quiburis Formation is not thought to extend below some roughly mid-Miocene ( $15 \mathrm{Ma})$ horizon. Most contacts between the Quiburis Formation and the San Manuel Formation are unconformable, with visible or mappable angularity (Figs. $36 \mathrm{I}$ and $37 \mathrm{O}$ ), and the San Manuel Formation is typically more indurated than the Quiburis Formation. Locally, however, the two units are concordant with no evidence of erosion or prolonged hiatus between the two depositional episodes (Figs. 35C and 37M). In these localities, Quiburis sedimentation evidently continued or resumed aggradation of fill within half-grabens or other depocenters where San Manuel strata had been preserved from erosion. Stacked paleosols indicative of successive stillstands and condensed sections occur along the concordant contacts, but the duration of the mid-Miocene hiatus recorded by the paleosols is unknown.

Quiburis equivalents. In outcrops at the foot of the Santa Catalina and Rincon mountains, probable equivalents of the
Quiburis Formation are exposed along the flank of the Tucson Basin (Table 7), but subsurface continuations apparently include multiple disconformities (Anderson, 1987). Unlike the underlying mid-Tertiary Pantano Formation, this basin fill contains conglomerates rich in mylonitic clasts derived from core rocks of the nearby Catalina core complex. In the basin depocenter, which was penetrated by an exploratory well, approximately $2,200 \mathrm{~m}$ of Miocene and younger basin fill are present above redbed strata correlative with the Pantano Formation (Eberly and Stanley, 1978). Parts of the subsurface succession may be correlative in part with the San Manuel Formation as well as with the Quiburis Formation of the San Pedro trough, but further study of well cuttings is needed to establish reliable ages for key subsurface horizons. In the Tucson Basin, the uppermost 100 to $120 \mathrm{~m}$ of basin fill designated as Fort Lowell Formation were deposited during initial Pleistocene integration of the existing Santa Cruz River drainage network (Davidson, 1973; Anderson, 1987).

Northwest of the Tucson Basin, the Red Rock Basin lying west of the Tortolita Mountains contains 1,200 to $1,500 \mathrm{~m}$ of basin fill, but is separated from the Tucson Basin by a shallow sill located between the Tortolita and Tucson Mountains (Eberly and Stanley, 1978). East of the Tortolita Mountains, gravity data imply the presence of thick asymmetric basin fill beneath Oro Valley, with the maximum depth to bedrock estimated as approximately $1,500 \mathrm{~m}$ adjacent to the Pirate fault along the western flank of the Santa Catalina Mountains (Budden, 1975).

Quaternary alluvium. Resting locally upon the Quiburis Formation and its equivalents, but not mapped separately for this study except along the well-defined modern floodplains of the Gila and San Pedro rivers, are gravel-rich Quaternary deposits from a few meters to a few tens of meters in thickness. This thin veneer of young sediment of varied origin and extent includes stream floodplains and wash floors, active pediments, both stream and pediment terraces, and local alluvial fans. Along the San Pedro trough, the fill of paleovalleys incised 25 to $75 \mathrm{~m}$ into the Quiburis Formation and the piedmont fans that flanked those paleovalleys were termed "Sacaton Formation" near Mammoth by Heindl (1963) and "Tres Alamos Formation" farther south near Redington by Montgomery (1963).

Terraces and benchlands. The occurrence of surficial sediment at multiple erosional levels within dissected basins reflects the tendency of arid landscapes to evolve as stepped transport surfaces mantled by reworked gravel layers capping successively formed benches (Melton, 1965). Polygenetic geomorphic surfaces that develop during dissection reflect episodic incision and aggradation in response to continued downcutting modulated by climatic fluctuations and to lateral cutting by migratory channels (Dethier and others, 1988). Grossly planar surfaces preserved at different elevations include stream terraces flanking present floodplains, pediments that truncate older basin fill, and aggradational alluvial fans.

The highest preserved gravel benches within sedimented basins of the study area record the maximum level of aggradation prior to dissection of basin fill during the erosional cycle initiated 
by integration of the Gila River system (Fig. 38). The general level of benchland surfaces preserves a fragmentary record of the paleolandscape that developed as structural relief, created by mid-Tertiary and basin-range taphrogenesis, was modified by evolving internal drainage systems of the study area.

The paleolandscape remnants are commonly marked in the field by a reddish argillic paleosol horizon underlain by petrocalcic layers. Resistant petrocalcic horizons are exposed at the surface where erosion has stripped away less-resistant soil materials during long exposure of paleosurfaces stranded on residual benchlands. The soil morphology of the paleosol on the Cordonnes surface (Fig. 38, CS), now preserved as a cluster of linear bifurcating ridges and interridge valleys radiating from the apex of a dissected alluvial fan, suggests that its origin dates from midPleistocene time or earlier (McFadden, 1981). There is no reason to suppose, however, that all remnants of the paleosurface marking the top of basin fill have the same geomorphic age at all localities. Logically, different remnants would have been stranded as benchlands standing above incised drainages at inherently different times as a regime of dissection spread progressively across the paleolandscape through headward erosion of Gila tributaries. Much more paleolandscape analysis is required to understand fully the degradational history of most basins within the study area. Local remnants of both the Sonoita and Martinez surfaces of Morrison (1985) may be prevalent.

In the southern San Pedro trough northeast of Redington Pass, several extensive remnants of the paleosurface stand at elevations near $1,250 \mathrm{~m}$, about $375 \mathrm{~m}$ above the floodplain of the San Pedro River (Fig. 38), at Davis Mesa (DM), Sol Rhea flat (SR), and Soza Mesa (SM). An observer occupying one of these residual benchlands with the modern San Pedro River valley hidden from view gains the illusion of standing within a broad valley with a nearly flat floor extending unbroken between the bedrock ranges on either side of the trough. The subdued character of the paleolandscape within basins of the study area is still preserved at Allen flat (Fig. 38, AF), where headward erosion by Hot Springs Canyon and Tres Alamos Wash (both tributary to the San Pedro River) has not yet destroyed the flat valley floor.

Farther north along the San Pedro trough, the elevation of the paleosurface descends gradually, to $1,225 \mathrm{~m}$ at Copper Creek (Fig. 38, CC) near Mammoth and to approximately $1,185 \mathrm{~m}$ as marked by narrow but accordant ridge crests between Copper and Aravaipa creeks. The floodplain of the modern San Pedro River lies some $525 \mathrm{~m}$ below these remnants of the paleolandscape. Still farther north, along the front of the Dripping Spring Mountains, similar accordant ridge crests stand at only 950 to $1,000 \mathrm{~m}$, but are still 400 to $450 \mathrm{~m}$ above the floodplain of the modern Gila River. The consistent change in elevation of the paleosurface along the trend of the San Pedro trough may reflect broad warping by subregional tilt to the north, but further study is required to confirm this effect. Bulk tilting of the whole San Pedro trough downward to the north could account, however, for the observation that correlative ash layers and enclosing lakebeds of the Quiburis Formation display a gentle northward slope $(\sim 0.004)$ along the course of the San Pedro River for a distance of 20 to $30 \mathrm{~km}$ south of Mammoth (Scarborough, 1975).

In uplands southwest of the San Pedro trough, a broad dissected paleosurface forms Falcon Divide (Fig. 38, FD) at an elevation of 1,100 to $1,150 \mathrm{~m}$ in the basin between the Santa Catalina, Tortolita, and Black mountains. Headward erosion by the drainages of Big Wash, Coronado Wash, and Camp Grant Wash is reducing its extent as dissection proceeds. To the east, exhumed and slightly dissected pediment near Oracle stands at 1,225 to $1,350 \mathrm{~m}$. Farther north, an undulating surface of pedimented granite masked by thin gravel cover extends northward at an elevation of about $1,250 \mathrm{~m}$ on the plateau extending from the Antelope Peak inselberg (Fig. 38) toward the Tortilla Mountains. These remnants of subdued paleotopography north of the Santa Catalina Mountains suggest that uplands in that region were bevelled to gentle relief during the time that basin fill was accumulating along the San Pedro trough to the east and within the Tucson Basin and related depocenters to the south. Throughout southern Arizona, pedimentation on basin flanks was commonly coeval with Neogene sedimentation in basin interiors (Scarborough, 1989).

In Cienega Gap east of the Tucson Basin and south of the Santa Catalina Mountains, remnants of the paleosurface capping basin fill are preserved at 1,175 to $1,300 \mathrm{~m}$ along the ridge south of Agua Verde Creek (Fig. 38, AV) and at 1,245 to $1,265 \mathrm{~m}$ on Mescal Divide (Fig. 38, MD) between the drainages of the Santa Cruz and San Pedro rivers. These high benchlands in Cienega Gap project southward 12 to $15 \mathrm{~km}$ to the still-undissected basin fill of Sonoita Valley, at an elevation of 1,350 to $1,575 \mathrm{~m}$ in the headwaters of Cienega Wash. Paleomagnetic studies of basin fill in Sonoita Valley indicate that its age ranges through much or all of Pliocene time (Menges and McFadden, 1981).

\section{SUBAREA STRUCTURE AND STRATIGRAPHY}

Figure 34 indicates the locations of key subareas where the stratigraphy and structure of mid-Tertiary strata are especially well displayed, and Figure 39 includes summary plots of paleocurrent indicators within the various subareas. Geologic relationships within the key subareas are described in order from north to south.

\section{Tortilla Mountains area}

The Tortilla Mountains (Fig. 40) southwest of the Gila River are composed of multiple eroded tilt-blocks exposing preTertiary bedrock, which underlies the higher ridges, overlain by Tertiary sedimentary successions, which underlie the intervening dissected lowlands (Fig. 41). The principal tilt-blocks expose homoclinal mid-Tertiary sequences that dip northeast and rest depositionally upon pre-Tertiary rocks along their southwest flanks. Basement exposures extend to paleodepths of 2.5 to $5 \mathrm{~km}$ within the up-ended tilt-blocks (Howard, 1991).

Although long segments of the basal contacts of the homo- 


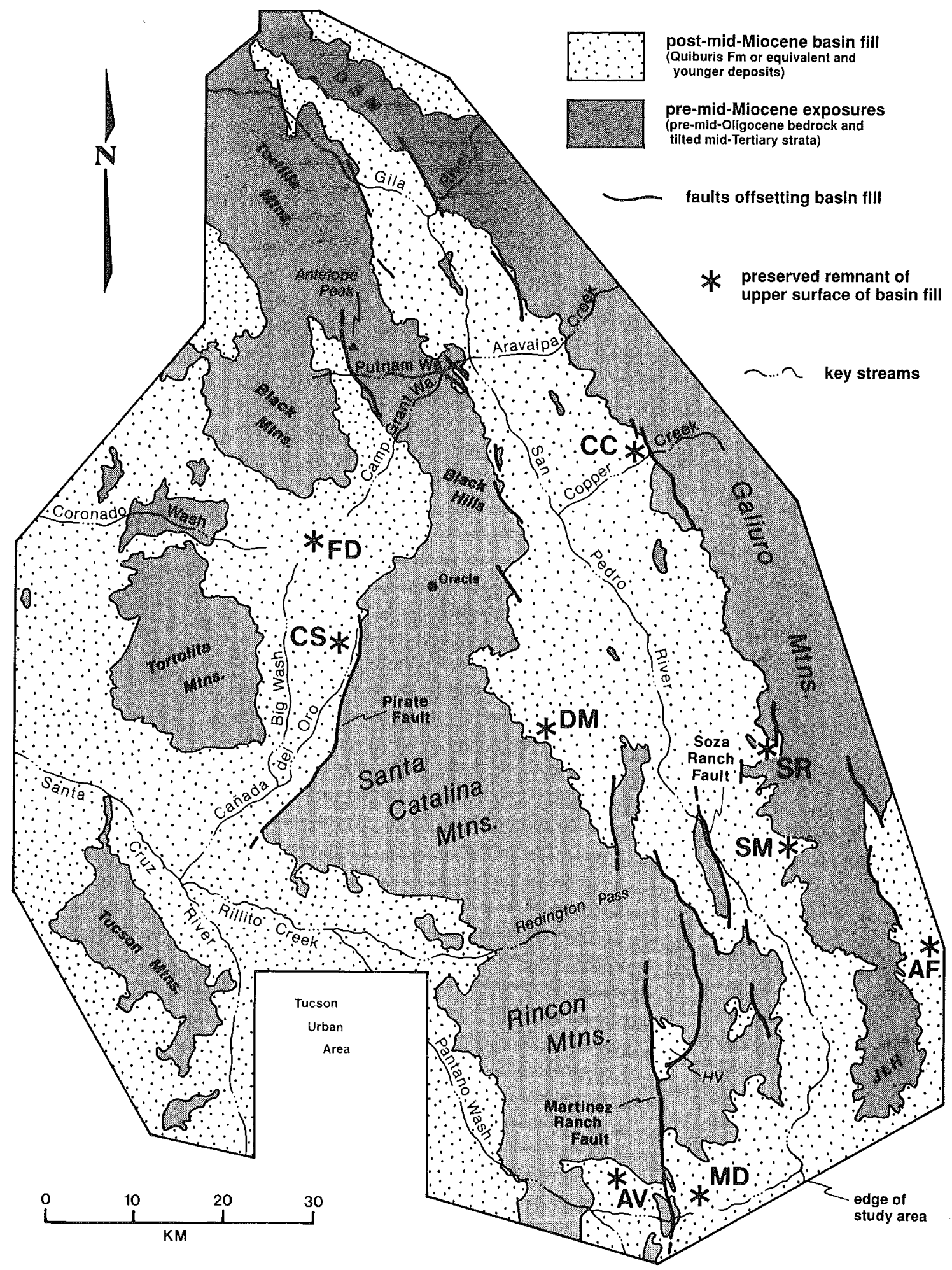

Figure 38. Distribution of post-mid-Miocene basin fill and location of key relict paleosurfaces marking uppermost level of basin fill prior to dissection by modern drainages; DSM, Dripping Spring Mountains; HV, Happy Valley; JLH, Johnny Lyon Hills. Weathered paleosurface remnants and their approximate present elevations above mean sea level (see text for discussion): AV, Agua Verde (1,175 to 1,200 m); AF, Allen flat $(\sim 1,375 \mathrm{~m})$; CC, Copper Creek $(\sim 1,225 \mathrm{~m})$; CS, Cordonnes Surface $(1,100$ to $1,150 \mathrm{~m})$; DM, Davis Mesa (1,225 to $1,300 \mathrm{~m})$; FD, Falcon Divide (1,100 to $1,150 \mathrm{~m})$; MD, Mescal Divide (1,245 to $1,265 \mathrm{~m})$; SM, Soza Mesa (1,235 to $1,285 \mathrm{~m})$; SR, Sol Rhea flat $(1,225$ to $1,275 \mathrm{~m})$. 
clines have been mapped previously as faults (Cornwall and Krieger, 1975a, b; Krieger, 1974c), their unconformable nature was established by Schmidt (1971). Outcrop evidence for depositional relations at the unconformities is unequivocal, but sedimentary onlap of basement surfaces preserving abrupt erosional relief has given rise to buttress unconformities with contacts inclined at an angle to bedding in overlying strata.

Along their northeast flanks, homoclines of mid-Tertiary strata are truncated downdip by normal faults with variable southwest dips (Fig. 42, A-A', B-B'). Homoclinal tilts that commonly fan up-section to shallower dips imply that many of the bounding faults were active during mid-Tertiary sedimentation. The faults project downdip into approximate alignment with subsurface reflectors that may represent intracrustal detachment surfaces (Naruk and others, 1986), but the relationship between these structures and the Catalina detachment system is uncertain.

Structural relations. Syntectonic mid-Tertiary strata of the Tortilla Mountains were deposited within multiple and compound half-graben basins, which evolved diachronously during sedimentation and have been dissected to varying structural levels. Stratigraphic relations change abruptly across major structural features. Approximately $3,750 \mathrm{~m}$ of concordant strata ranging in probable age from mid-Oligocene to mid-Pliocene are present as a homoclinal succession exposed along a transect across the keel of the San Pedro trough near Kearny in the Gila River valley (Fig. 35C). Nearby in the subsurface, however, complex stratal onlap and overstep of buried tilt-blocks are inferred from projection of structures along strike (Fig. 42, A-A'). Thin successions of uppermost Cloudburst Formation (not depicted in the subsurface), may have overstepped the bounding faults, for analogous strata are present in outcrops farther southeast (Fig. 40).

Elsewhere within the Tortilla Mountains, evidence for analogous onlap and overstep of eroded tilt-blocks is present in surface exposures as buttress nonconformities and angular discordances at the basal contacts of both the San Manuel and Quiburis Formations (Fig. 40): (1) along Ripsey Wash west of the Ripsey fault, the San Manuel Formation rests nonconformably on Precambrian granitic basement rocks; (2) near Ripsey Hill, the angular discordance between steeply dipping beds in the Hackberry Wash facies of the Cloudburst Formation and overlying strata of the San Manuel Formation is approximately $40^{\circ}$ in the west limb of a local syncline, the axial trace of which crosses Jim Thomas Wash; (3) southwest of Crozier Peak, strata of the San Manuel Formation overstep the Hackberry Wash facies of the Cloudburst Formation to rest directly on Precambrian rocks; (4) northwest of Kearny (near Kelvin), nearly flat-lying strata of the Quiburis Formation rest unconformably on strongly tilted beds in the Hackberry Wash facies of the Cloudburst Formation and cover the fault that places the latter sequence against basement rocks near the northern edge of Figure 40; (5) along the eastern flank of the Tortilla Mountains east of Crozier Peak, strata of the Quiburis Formation dipping gently into the San Pedro River valley overlie tilted San Manuel Formation with an angular discordance of approximately $20^{\circ}$.
Steeply dipping homoclines, nearly vertical locally, of Precambrian Apache Group and Troy Quartzite lie unconformably beneath the Hackberry Wash facies of the Cloudburst Formation in exposures flanking several tilt-blocks. Varying amounts of angular discordance across the contact reflect variable tilt of the pre-Tertiary substratum prior to the onset of syntectonic midTertiary sedimentation, but show generally that Precambrian beds dipped gently prior to mid-Tertiary deformation. The uniformly steep dips of Precambrian strata that flank up-ended tiltblocks in the Tortilla Mountains differ markedly from the comparatively gentle dips of correlative Precambrian and overlying Paleozoic strata that form much of the Dripping Spring Mountains northeast of the San Pedro trough (Figs. 1 and 2). The strong contrast in structural style across the Gila River valley attests to the vigor of mid-Tertiary extensional deformation along the buried axis of the San Pedro trough (Schmidt, 1971; Naruk and others, 1986).

Krieger (1974a) concluded that steep stratal dips ascribed here to the evolution of multiple fault-bounded tilt-blocks instead reflect mid-Tertiary monoclinal folding of Precambrian basement, together with its stratigraphic cover. In her interpretation, the repeated homoclinal sections are viewed as offset segments of the resulting giant monocline. Contrasts in mid-Tertiary stratigraphic sequences preserved within different half-graben basins located between the various tilt-blocks argue against her concept of a faulted monocline.

The syncline with its axial trace crossing Jim Thomas Wash in the structural block lying between the Ripsey and Hackberry faults (Figs. 40 and 42, B-B') is a prominent exception to the characteristic northeasterly homoclinal dips of mid-Tertiary strata. This structure appears to be the only local record of contractional deformation. Its geometry is attributed (after Naruk and others, 1986) to draping of strata in kinematic response to the movement of the hanging wall of a complex normal fault system over linked fault segments with variable dips that form a flatramp-flat geometry (Armstrong, 1972; Gibbs, 1984). Kink folds in strata of the Hackberry Wash facies of the Cloudburst Formation dipping in opposite directions east and west of the Hackberry fault (Fig. 40) have middle limbs rotated in opposite senses to uniformly subhorizontal dips (Naruk and others, 1986). The orientation of the kinking is interpreted to reflect horizontal extensional strain in both fold limbs.

Most exposed normal faults in the Tortilla Mountains dip at moderate $\left(40\right.$ to $\left.50^{\circ}\right)$ to steep $\left(70\right.$ to $\left.80^{\circ}\right)$ angles to the southwest, although one exposed fault northeast of Crozier Peak (Figs. 40 and $\left.42, \mathrm{~B}-\mathrm{B}^{\prime}\right)$ dips gently $\left(20\right.$ to $\left.30^{\circ}\right)$ to the southwest. Some individual faults, such as the Ripsey fault (Fig. 40), change dip substantially along strike. Exposed field relations are inadequate to test whether individual faults are listric or rotated bodily during offset. In either case, consistent dihedral angles of 60 to $75^{\circ}$ between fault planes and bedding in syntectonic strata imply that faults active at shallow depths dipped at steep angles where they first cut sedimentary horizons that were still subhorizontal. Faults are shown as mildly listric on cross sections (Fig. 42, A-A', B-B'), 


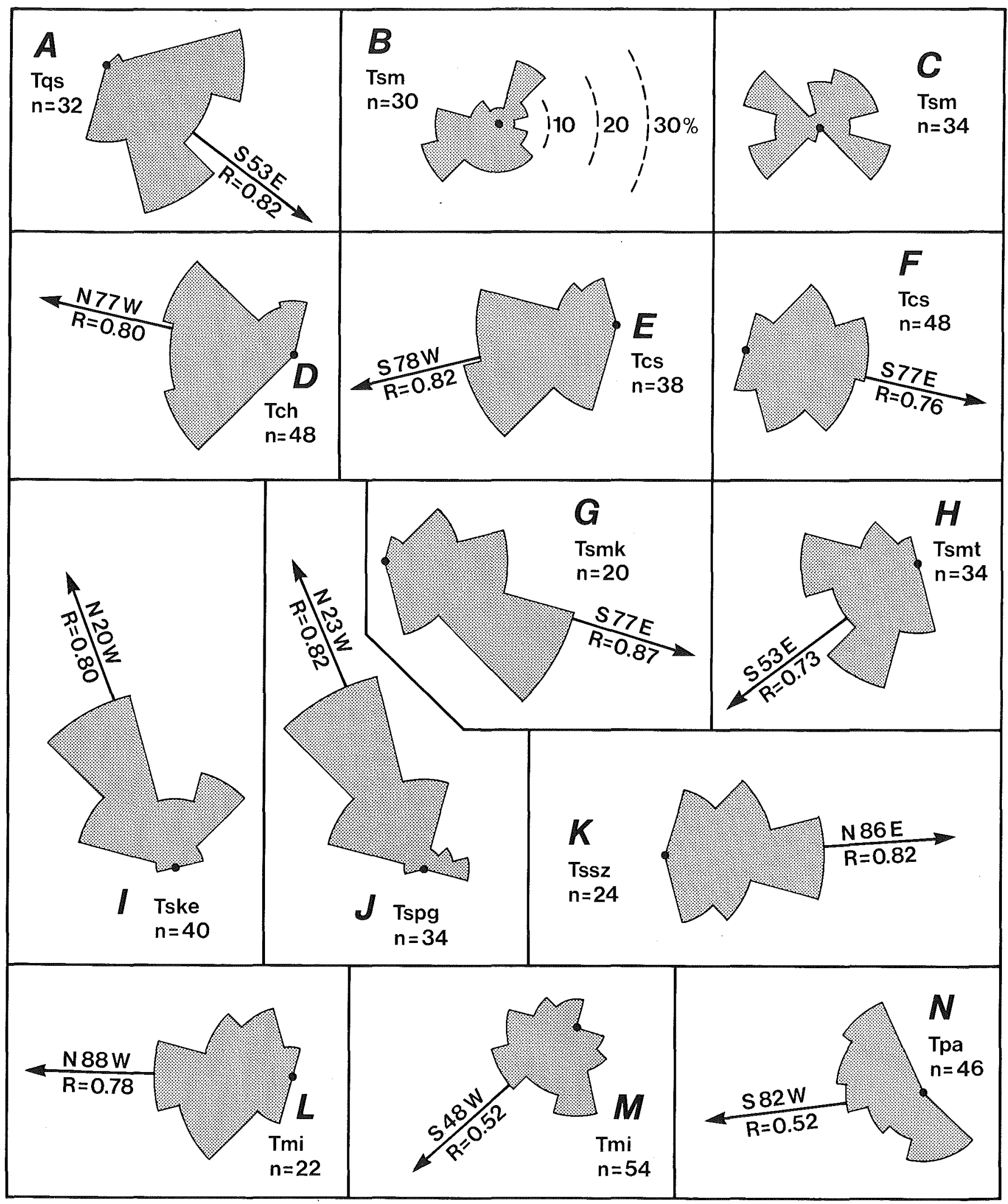


but this schematic convention is not meant to deny possible bodily rotation of fault surfaces.

Progressive shallowing of stratal dips up-section across the complex homocline underlying the Gila River valley (Figs. 40 and $42, A-A^{\prime}$ ) requires the presence in the subsurface of either listric or rotated syndepositional faults bounding buried tiltblocks of the San Pedro trough. The abrupt change in the inclination of fault blocks, from quasihorizontal attitudes in the Dripping Spring Mountains to subvertical tilt-blocks in the Tortilla Mountains only 5 to $10 \mathrm{~km}$ away, argues that key master faults hidden by syntectonic sediment cover are listric to some degree. Dip variations within the compound homocline along Ripsey Wash (Fig. 40) are less marked, but compatible with modest listric curvature for the Ripsey Wash fault. Configurations of other major faults within the Tortilla Mountains are uncertain or complex.

Hackberry Wash Facies of Cloudburst Formation. The Hackberry Wash facies of the Cloudburst Formation reaches a maximum thickness of approximately $2,000 \mathrm{~m}$ within the half- graben basin exposed southwest of Kearny (Figs. 35C and 40), but is much thinner or absent elsewhere. This redbed unit of dominantly brownish coloration is well indurated and lithologically varied, but is composed mainly of alluvial fan and braidplain facies. The strata have been described previously as "dark conglomerate" grading into "dark playa deposits" (Cornwall and Krieger, 1975a; Banks and Krieger, 1977), or simply as "nongranitic alluvial deposits" (Krieger, 1974b, c), and treated as a basal part of the overlying San Manuel Formation. Lower parts of the Hackberry Wash facies exposed near Indian Camp Wash (Fig. 40) are reddish proximal alluvial fan deposits composed of intercalated debris-flow and streamflood layers (Fig. 43). Lower parts of the unit farther west above the steeply tilted unconformity near Hackberry Wash include thick debris-avalanche megabreccias (Figs. 26 and 27). A thin lens of andesitic lava and flowbrecca (Table 7) is intercalated within basal beds along upper Jim Thomas Wash (Figs. 35B and 40). Upper parts of the Hackberry Wash facies as exposed along both Hackberry and Indian Camp washes (Fig. 40) are finer-grained deposits, of
Figure 39. Reconnaissance paleocurrent roses (total $n \sim 500$ ) for selected syntectonic sedimentary sequences exposed along and near the San Pedro trough. Radii of rose segments (each $30^{\circ}$ ) are proportional to percentage of restored paleocurrent vectors falling within each azimuthal grouping (scale in B). Number (n) of readings for each rose refers to number of outcrops where bulk orientation of groups of imbricated clasts was measured in single or associated beds. Arrows denote vector means of paleoflow directions represented by roses. As a measure of data dispersion, magnitude $(R)$ of resultant vector indicates proportion of ideal length (at $R=1.0$, all paleoflow directions would be perfectly aligned), and equals consistency ratio $(\mathrm{R} / \mathrm{n})$ of Reiche (1938). A, Quiburis Formation ("Big Dome Formation" of Cornwall and Krieger, 1975a): exposures in two narrow gulches with steep walls incised into dissected basin fill and draining from front of Dripping Spring Mountains toward Gila River northwest of Kearny (Fig. 40); net paleoflow to southeast reflects trunk paleodrainage parallel to structural trend of San Pedro trough from its northwesternmost extremity. B, San Manuel Formation: cliff exposures in deep gorges along Ripsey Wash (Fig. 40) west of Tortilla Mountains; diverse paleoflow directions without strong vector mean reflect generally centripetal paleodrainage transporting mainly granitic detritus into local half-graben basin from surrounding basement uplands. C, San Manuel Formation: exposures west of Hackberry fault (Fig. 40) in Tortilla Mountains (along Jim Thomas, Eagle, and Hackberry washes and in steep walls of "Corkscrew Canyon" between Eagle Wash and upper Hackberry Wash); diverse paleoflow directions without strong vector mean reflect generally centripetal paleodrainage transporting dominantly granitic detritus into composite basin of multiple half-grabens. D, Hackberry Wash facies of Cloudburst Formation: exposures flanking Tortilla Mountains (Fig. 40) along Hackberry, Indian Camp, and Smith Washes south of Gila River; net WNW paleoflow reflects sediment derivation from varied sources in Dripping Spring and Galiuro Mountains northeast of San Pedro trough. E, sedimentary upper member of Cloudburst Formation: exposures along Camp Grant Wash (Fig. 46) in Putnam Wash area northwest of Black Hills; net WSW paleoflow reflects sediment derivation from frontal scarp(s) of eroded tilt-block(s) within San Pedro trough northeast of present trace of San Manuel/Camp Grant fault system. F, sedimentary upper member of Cloudburst Formation: exposures within Black Hills (Fig. 49) in Cloudburst and Tucson washes; net ESE paleoflow reflects sediment derivation from backslope of eroded tilt-block flanking San Pedro trough north of Catalina core complex. G, Kannally Member of San Manuel Formation: exposures along Putnam Wash (Fig. 46) near Antelope Peak and within Black Hills (Fig. 49) between Oracle and Mammoth; net ESE paleoflow reflects derivation of mainly granitic detritus from basement uplands north of Catalina core complex. H, Tucson Wash Member of San Manuel Formation: exposures along east flank of Black Hills (Fig. 49) in Tucson, Mammoth, Cottonwood, and Smelter washes; net paleoflow to southwest reflects sediment derivation from tilt-blocks within San Pedro trough and/or from breakaway zone along southwest front of Galiuro Mountains. I, Kelsey Canyon facies of San Manuel Formation: outcrops south of Galiuro Mountains (Fig. 52) in Hot Springs and Sierra Blanca canyons on the north, along Teran Wash, and in Kelsey Canyon on the south; net NNW paleoflow reflects derivation of dominantly granitic detritus from Precambrian basement of Johnny Lyon Hills. J, Paige Canyon facies of San Manuel Formation: exposures along Paige Canyon (Fig. 52) between Rincon and Little Rincon Mountains; net NNW paleoflow reflects derivation of mainly metamorphic detritus from Laramide tectonites (core rocks) of Little Rincon Mountains. K, Soza Canyon facies of San Manuel Formation: exposures in Soza and Roble canyons (Fig. 52) just west of San Pedro River east of Rincon Mountains and Redington Pass; net easterly paleoflow reflects derivation of dominantly volcanic detritus from Galiuro Volcanics since largely stripped from underlying Mineta Formation now exposed along Cañada Atravesada between Soza and Roble Canyons. L, Mineta Formation: exposures in type area near Cañada Atravesada between Soza and Roble canyons (Fig. 52) on eastern flank of Rincon Mountains; net westerly paleoflow reflects sediment derivation from varied sources in tilt-blocks now buried beneath San Pedro trough (Olivares, 1991). M, Mineta Formation: exposures near Teran Wash and Kelsey Canyon (Fig. 52) east of San Pedro River; net paleoflow to southwest reflects sediment derivation from varied sources in eroded fault blocks of southern Galiuro Mountains (Grover, 1982). N, Pantano Formation: exposures along Cienega Creek and in roadcuts on Interstate Highway 10 in type area near Cienega Gap south of Rincon Mountains (Figs. 1 and 2); net westerly paleoflow reflects partly centripetal paleodrainage from sediment sources in Bisbee Group and Laramide igneous rocks of nearby uplands (Balcer, 1984). 


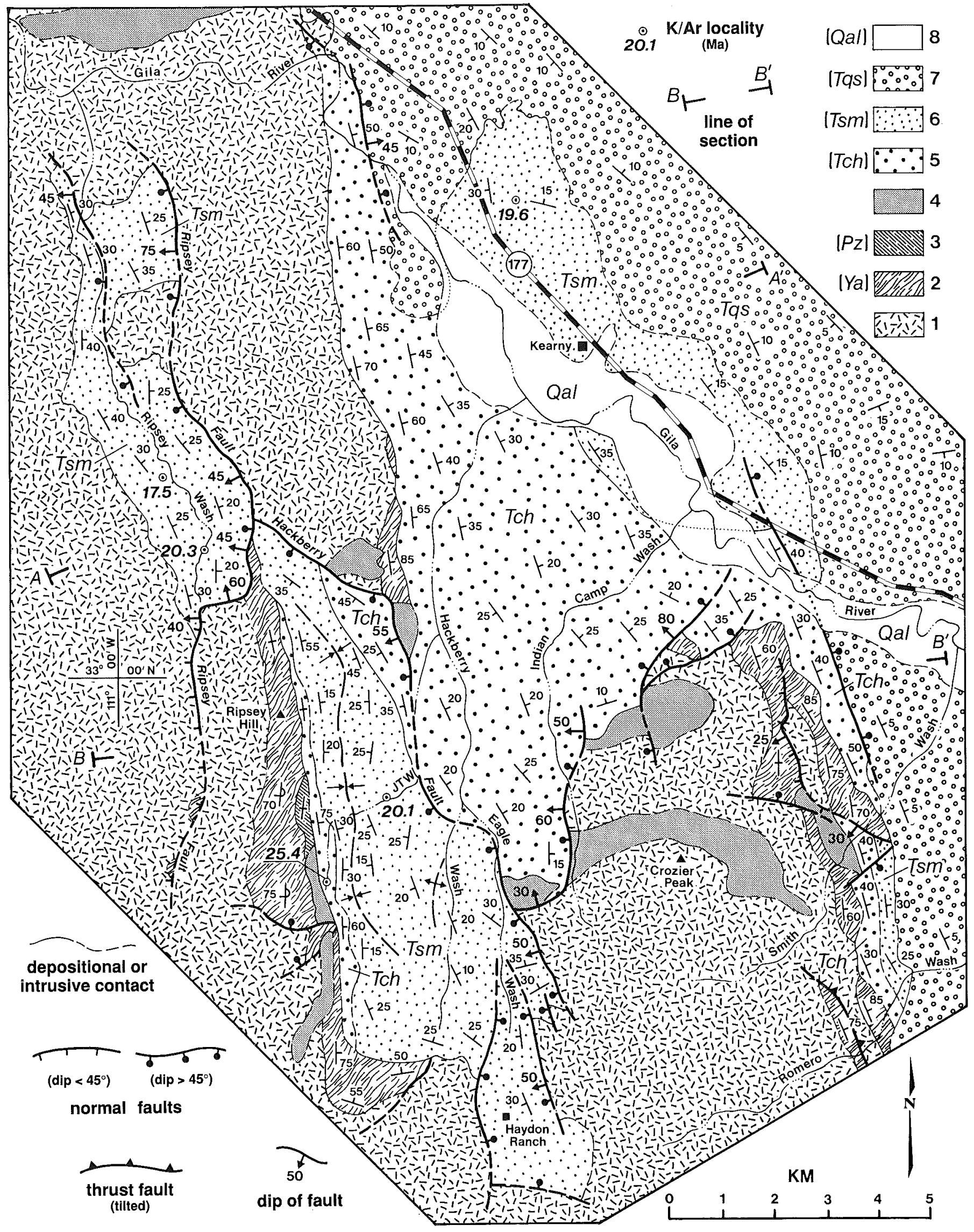


somber brown hue, that display sheet-like interbedding of horizontally laminated sandstone, claystone seams with local mudcracks, and massive pebbly mudstone in laterally continuous thin layers (Figs. 44 and 45). This mix of stratal types is interpreted to reflect deposition by sheetflow spreading across the surfaces of distal alluvial fans.

Dominant paleocurrent trends in the Hackberry Wash facies are westerly, with a WNW vector mean (Fig. 39D). The indicated provenance east of the San Pedro trough is the crustal block including the Dripping Spring and northern Galiuro mountains, where eroded sources for all the prominent clast types are present. The most abundant clasts in conglomerate are limestone and quartzite derived mainly from Paleozoic sequences, but partly from underlying Precambrian strata, and dark andesitic volcanic rocks of the Laramide Williamson Canyon Volcanics. Subordinate clasts include Precambrian diabase, more felsic Laramide volcanic rocks, and Laramide granitic rocks.

Despite consistent paleocurrent indicators documenting westerly stream flow during accumulation of the bulk of the Hackberry Wash facies, the large megabreccia bodies exposed near Hackberry Wash were emplaced from the west (Schmidt, 1971; Krieger, 1974a, 1977). These sheet-like masses are composed dominantly of jumbled and shattered Precambrian and Paleozoic sedimentary units, but also include debris from Precambrian granite and diabase (Schmidt, 1971; Krieger, 1974c; Cornwall and Krieger, 1975a). They were derived from the backtilted flank of the now-denuded tilt-block lying immediately to the west before combined avalanching and erosion had stripped cover strata from the underlying Precambrian basement. The aggregate thickness of partly amalgamated and partly discrete megabreccia lenses reaches almost $250 \mathrm{~m}$. As tilting and subsidence continued, aggradation of alluvial fan and braidplain facies derived from east of the keel of the San Pedro trough evidently prograded across the evolving half-graben system to bury the backslope of the tilt-block.

The uppermost subunit of the Hackberry Wash facies south of Kearny (Fig. 40) is dark lacustrine mudstone (Table 7) approximately $75 \mathrm{~m}$ thick. This lacustrine subunit is overlain gradationally by coarser clastic deposits composed mainly of granitic detritus in the overlying San Manuel Formation. At the contact, basal pebbly sandflat deposits grading upward to alluvial fan and

Figure 40. Geologic sketch map of Tortilla Mountains area (see Fig. 34 for location) near Kearny on Gila River; JTW, Jim Thomas Wash. Modified after Schmidt (1971), Krieger (1974b, c), Cornwall and Krieger (1975a, b), and Banks and Krieger (1977). See Figure 35 for columnar sections of mid-Tertiary and younger strata exposed along Ripsey (column A), Jim Thomas (column B), and Hackberry (column C) washes. Legend: 1, Precambrian basement; 2, Proterozoic strata (Apache Group and Troy Quartzite including intrusive diabase sills); 3, Paleozoic strata; 4, Laramide igneous rocks (dominantly intrusive); 5, Hackberry Wash facies (Tch) of Cloudburst Formation; 6, San Manuel Formation (Tsm); 7, Quiburis Formation (Tqs) together with overlying terrace and pediment gravels; 8, Quaternary alluvium (Qal) along floodplain of Gila River.

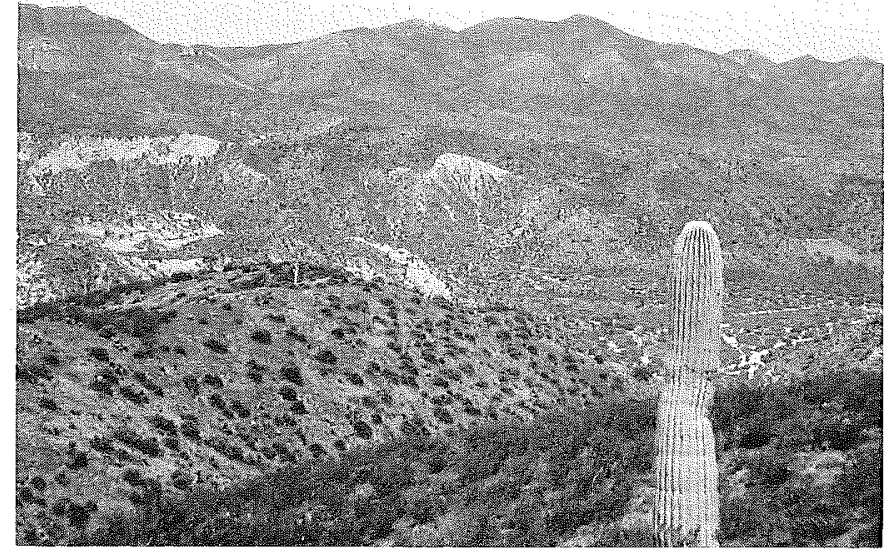

Figure 41. Landscape of Tortilla Mountains in view northwest toward Ripsey Hill across drainage of Hackberry Wash. Pre-Tertiary bedrock outcrops along skyline ridge. Tilted mid-Tertiary strata exposed beneath dissected benchlands capped by pediment gravels in foreground and middle ground.

braidplain facies record eastward progradation of a local fan delta into the lacustrine environment.

San Manuel Formation. The San Manuel Formation is less indurated than the underlying Hackberry Wash facies of the Cloudburst Formation, contains dominantly granitic detritus, and reaches a thickness of approximately $1,250 \mathrm{~m}$ along the northern edge of the Tortilla Mountains. The strata have been described previously as "granitic alluvial deposits" and "granitic conglomerate" assigned in part to the "Big Dome Formation" (Cornwall and Krieger, 1975a, b; Krieger, 1974b, c). As originally defined, the "Big Dome Formation" (Krieger and others, 1974) includes reworked clasts of reddish Apache Leap Tuff, an ignimbrite unit of early Miocene age ( $20 \mathrm{Ma})$ exposed widely in the region north of the Gila River. Near Kearny (Fig. 40), $10 \mathrm{~m}$ of pink ash-flow tuff, originally mapped as intercalated within the "Big Dome Formation," is probably a distal finger of Apache Leap Tuff and has yielded a coincident K-Ar age (Dickinson and Shafiqullah, 1989). The enclosing conglomeratic strata with abundant granitic clasts are included here within the San Manuel Formation (Fig. 35C). Historically, much of the argument for the existence of "Big Dome Formation" separate from the San Manuel and Quiburis Formations stemmed from spurious mid-Miocene $\mathrm{K}-\mathrm{Ar}$ ages for the pink ash-flow tuff near Kearny (Dickinson and Shafiqullah, 1989).

Within the Tortilla Mountains, incomplete sections of San Manuel Formation overlap more steeply dipping older beds in the Hackberry Wash facies of the Cloudburst Formation with angular unconformity, or else overstep underlying Tertiary strata entirely to rest nonconformably on Precambrian basement. Conglomeratic strata of alluvial fan and braidplain facies are characteristic, but an interval of horizontally laminated tuffaceous sandstone nearly $75 \mathrm{~m}$ thick is prominent near the middle of the succession exposed along Ripsey Wash (Cornwall and Krieger, 1975a, b). Granitic clasts derived from the middle Proterozoic Oracle/Ruin granite suite are predominant in most exposures, 

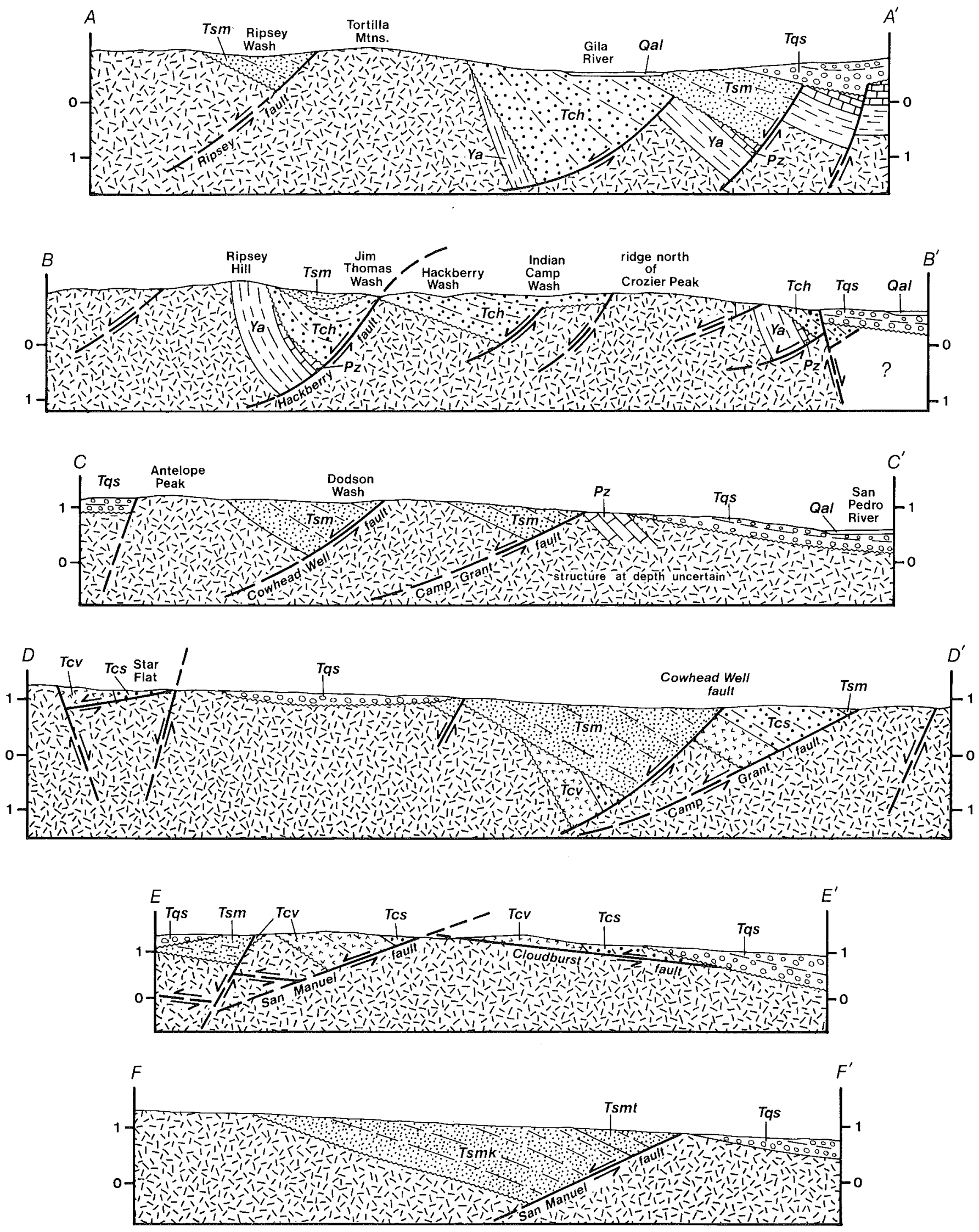


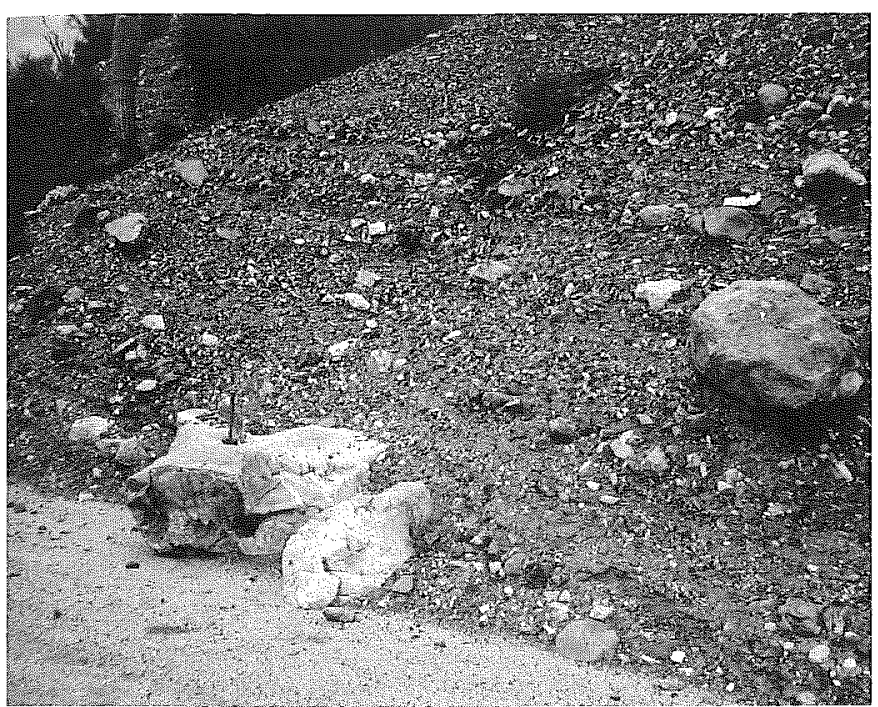

Figure 43. Proximal alluvial fan deposit in lower part of Hackberry Wash facies of Cloudburst Formation along Indian Camp Wash in Tortilla Mountains (hammer in lower left for scale).

although clasts derived from Precambrian and Paleozoic sedimentary rocks and from Laramide plutons are also present in typical outcrops.

Paleocurrent roses for exposures of San Manuel Formation along Ripsey Wash and east of Ripsey Hill (Fig. 40) display wide scatter (Fig. 39B and C), which suggests generally centripetal drainages. Isolated half-graben basins were infilled with debris derived from adjacent sources in bounding tilt-blocks of the evolving Tortilla Mountains. The composite provenance for San Manuel deposits was the array of eroded tilt-blocks exposing basement within the Tortilla Mountains. Exposures of San Manuel Formation along the Gila River valley near Kearny were also doubtless derived from the Tortilla Mountains to the southwest, for the Dripping Spring Mountains on the northeast could not have supplied the requisite granitic detritus.

Air-fall tuff layers $(\sim 20 \mathrm{Ma})$, each less than $1 \mathrm{~m}$ thick where exposed along Ripsey and Jim Thomas washes (Figs. 35A, B, and 40), are interpreted provisionally as co-ignimbrite ash from Apache Leap eruption clouds (Dickinson and Shafiqullah, 1989). The air-fall ash horizons are only $\sim 300 \mathrm{~m}$ above the unconform-

Figure 42. Interpretive geologic cross sections (with topography approximate) of Tortilla Mountains (Fig. 40, $\mathrm{AA}^{\prime}$ and $\mathrm{BB}^{\prime}$ ), Putnam Wash (Fig. 46, $\mathrm{CC}^{\prime}$ and $\mathrm{DD}^{\prime}$ ), and Black Hills (Fig. 49, $\mathrm{EE}^{\prime}$ and $\mathrm{FF}^{\prime}$ ) areas. Pre-Tertiary strata: Ya, Proterozoic Apache Group and Troy Quartzite including intrusive diabase sills; $\mathrm{Pz}$, varied Paleozoic units. Cloudburst Formation: Tcv, volcanic lower member; Tch, Hackberry Wash facies; Tcs, sedimentary upper member. San Manuel Formation; Tsmk, Kannally (lower) Member; Tsm, undifferentiated; Tsmt, Tucson Wash (upper) Member. Quaternary alluvium differentiated from post-midMiocene basin fill (Tqs, Quiburis Formation and equivalent strata grouped together with younger terrace and pediment gravels) only along floodplains of Gila and San Pedro rivers. Scale in $\mathrm{km}$ (no vertical exaggeration).

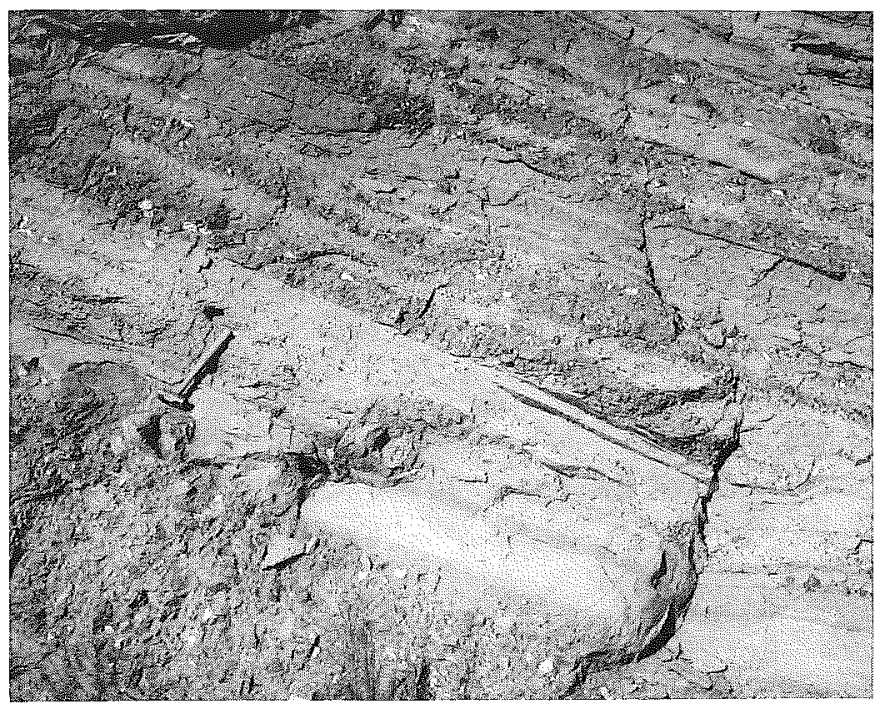

Figure 44. Interbedded sandstone and conglomerate with mudstone seams in upper part of Hackberry Wash facies of Cloudburst Formation along Hackberry Wash in Tortilla Mountains (hammer for scale).

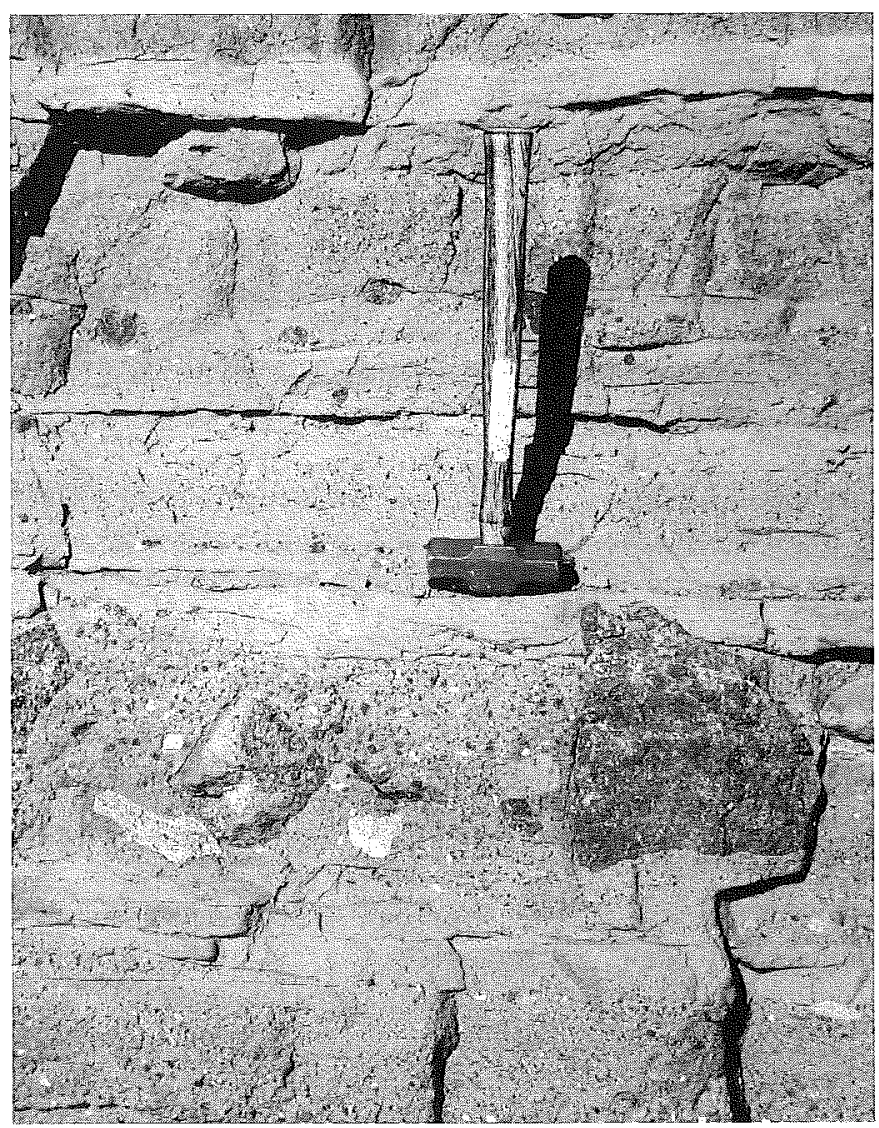

Figure 45. Pebbly mudstone layers deposited by thin overbank debris flows spread over an alluvial fan surface by sheetflood in upper part of Hackberry Wash facies of Cloudburst Formation along Hackberry Wash in Tortilla Mountains (note clast imbedded in coarsest layer protruding into overlying finer-grained layer below and to right of hammerhead). 
able base of the San Manuel Formation. The correlative pink ignimbrite horizon near Kearny is $\sim 1,000 \mathrm{~m}$ above the base of the formation along the keel of the San Pedro trough. This difference in stratigraphic position is a measure of the degree of onlap of eroding tilt-blocks during subregional aggradation that resulted in gradual burial of the tilt-blocks beneath aprons of their own detritus.

The contrasting stratigraphy of homoclinal sequences in half-graben basins along Ripsey and Hackberry Washes (Fig. 40) reflects the diachronous timing of tilt-block development in the Tortilla Mountains. While a thick succession of Hackberry Wash facies of the Cloudburst Formation was accumulating along Hackberry Wash, the area around Ripsey Wash was still undergoing erosion, and may have been part of the area that shed debris avalanches to form the megabreccia lenses so prominent along Hackberry Wash. Later faulting downdropped the Ripsey Wash half-graben and allowed deposition of the San Manuel Formation there as well as above the older mid-Tertiary strata preserved along Hackberry Wash. Within intervening ground between the Ripsey and Hackberry faults (Fig. 40), a thin truncated section of Hackberry Wash facies of the Cloudburst Formation is overlain with angular unconformity by the San Manuel Formation. These structural and stratigraphic relations imply progressive expansion of the tilt-block field in the Tortilla Mountains as active faulting stepped sequentially westward with time.

Quiburis Formation. Just northeast of the Gila River along the axis of the San Pedro trough, the gently deformed and variably indurated Quiburis Formation locally rests concordantly upon the San Manuel Formation. The contact between gray beds composed almost entirely of granitic detritus in the San Manuel Formation below, and tawny beds composed of polymictic conglomerate above, is marked by a caliche-rich horizon interpreted as a paleosol indicative of condensed sedimentation and a hiatus of unknown duration. Gravel in the Quiburis Formation, which reaches a thickness of perhaps $500 \mathrm{~m}$ within the Gila River valley, is composed of clasts derived from all the rock units presently exposed in the Dripping Spring and Tortilla Mountains flanking the San Pedro trough. Gravel clasts, in proportions varying with relative proximity to specific sources, include Precambrian granite and schist, Precambrian and Paleozoic quartzite and limestone, and Laramide igneous rocks, both intrusive and extrusive. Of special significance are sparse but ubiquitous rounded clasts of pink to red Apache Leap Tuff containing phenocrysts of biotite, quartz, sanidine, and plagioclase. Such clasts are absent from all older conglomerates of the Tortilla Mountains.

Gently deformed conglomeratic beds deposited along the axis of the San Pedro trough in the valley of the Gila River, and designated here as Quiburis Formation, formed the main body of the "Big Dome Formation" (Cornwall and Krieger, 1975a) of Krieger and others (1974), and had previously been assigned to the "Gila Conglomerate" by Schmidt (1971). At Hayden, where the San Pedro River joins the Gila River, strata mapped as "Big Dome Formation" along the Gila River valley (Banks and Krieger, 1977) pass laterally without break into strata mapped as
Quiburis Formation along the San Pedro River valley (Krieger, 1974b). Farther southeast, parts of the Quiburis Formation onlapping the flank of the Tortilla Mountains along the edge of the San Pedro River valley were also mapped as "Big Dome Formation" by Krieger (1974b), but the supposed contact with the Quiburis Formation was queried and no actual distinction between the adjacent exposures can be made.

Some strata of the Quiburis Formation represent dissected alluvial fans of variable but restricted composition built laterally into the San Pedro trough from individual local drainages. For example, basal strata near Big Dome at the northwestern extremity of the San Pedro trough contain entirely granitic detritus (Cornwall and others, 1971), whereas strata that lap against the flank of the Dripping Spring Mountains contain either limestone or volcanic clasts (Cornwall and Krieger, 1975a; Banks and Krieger, 1977). Paleocurrent indicators from the main body of the Quiburis Formation within the Gila River valley record longitudinal paleoflow southeasterly along the axis of the San Pedro trough (Fig. 39A). A broad composite fan or braidplain confined within the structural trough evidently sloped toward the depositional site of lacustrine facies in the Quiburis Formation of the San Pedro River valley.

Exposures of Quiburis Formation along the Gila River valley are partly masked over wide areas by younger terrace and pediment gravels capping multiple degradational surfaces. Correlative geomorphic features extend into broad areas of subdued relief underlain by tilted sedimentary sequences within the Tortilla Mountains to the southwest (Fig. 41).

\section{Putnam Wash area}

The Putnam Wash area (Fig. 46), west of the confluence of Aravaipa Creek with the San Pedro River, includes broad uplands lying northeast of the Black Mountains, southwest of the San Pedro River valley, and northwest of the Black Hills. The most prominent topographic feature is Antelope Peak, a residual granitic hill or inselberg that rises above the level of intricately dissected pediment surfaces, which cap the surrounding uplands (Fig. 47). Tilted mid-Tertiary strata are exposed in the valleys of multiple washes that drain toward the San Pedro River and near Star Flat at the foot of the Black Mountains. Gently dipping

Figure 46. Geologic sketch map of Putnam Wash area (see Fig. 34 for location) between Tortilla Mountains and Black Hills; SFf, Star Flat fault (detachment fault beneath Star Flat allochthon). Modified after Krieger (1968d, 1974b, d, e) and Hansen (1983). See Figures 35 and 36 for columnar sections of mid-Tertiary and younger strata exposed along Putnam Wash near Antelope Peak (column D), along Camp Grant Wash (column E), and at Star Flat (column G). Legend: 1, Precambrian basement; 2, Proterozoic strata (Apache Group and Troy Quartzite including intrusive diabase sills); 3, Paleozoic strata; 4, volcanic lower member (Tcv) of Cloudburst Formation; 5, sedimentary upper member (Tcs) of Cloudburst Formation; 6, San Manuel Formation (Tsm); 7, Quiburis Formation (Tqs) together with overlying terrace and pediment gravels and correlative upland gravel cover; 8, Quaternary alluvium (Qal) along floodplain of San Pedro River. 


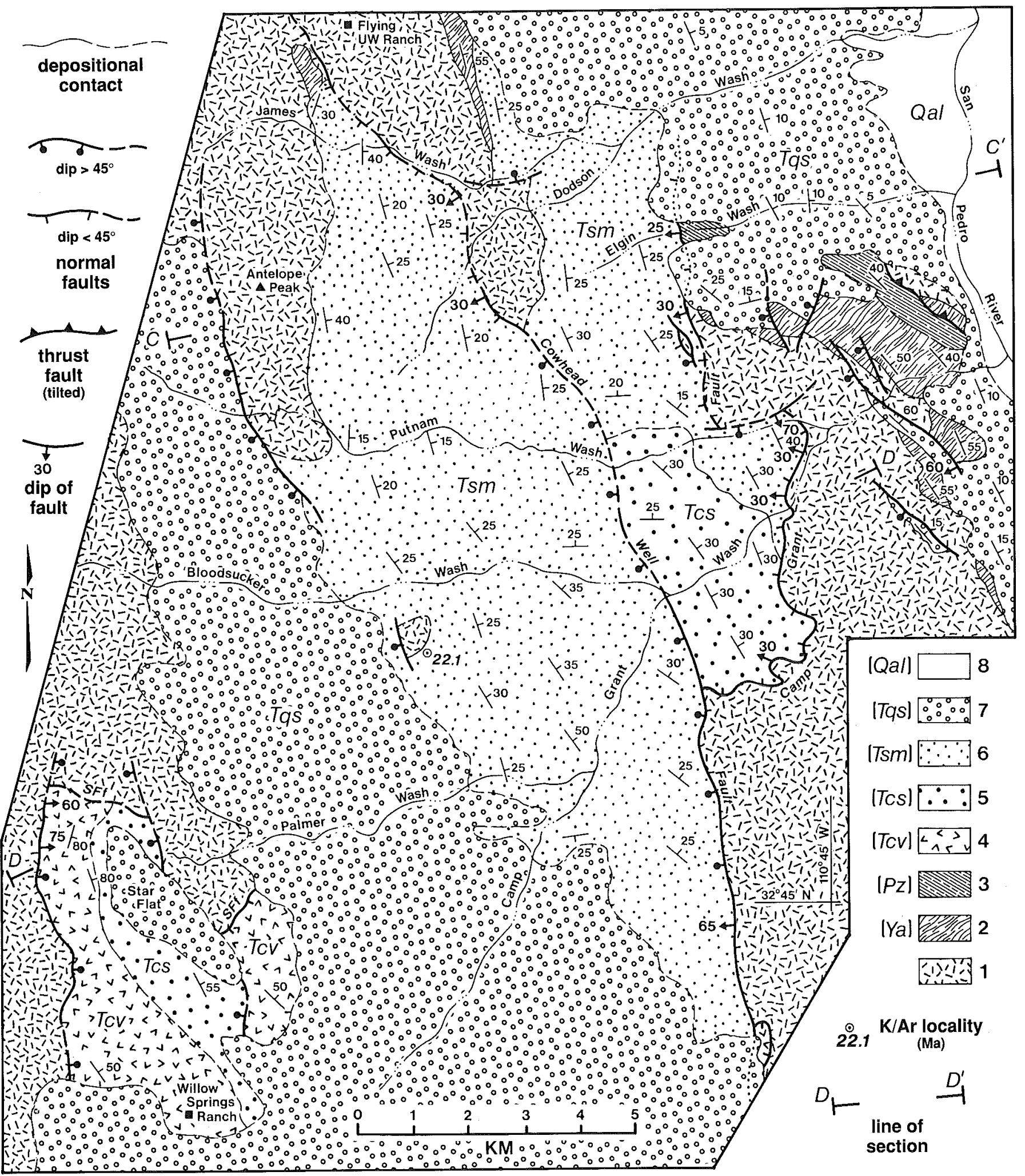




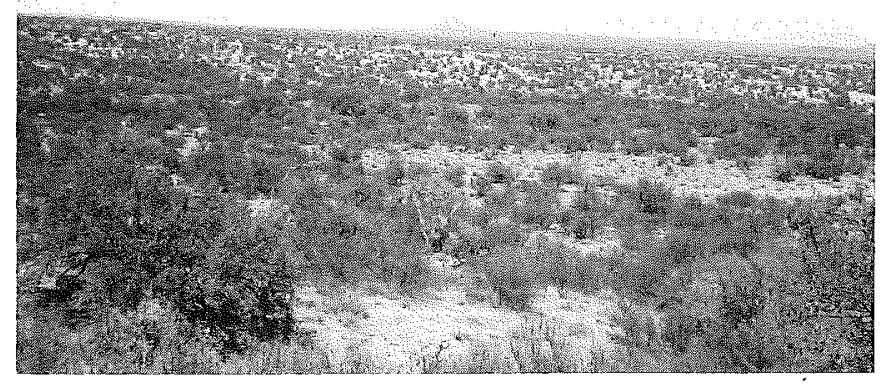

Figure 47. View north across uplands dissected by tributaries of Putnam Wash toward Antelope Peak (center), a relict inselberg projecting above the prevailing level of Neogene pedimentation north of the Catalina core complex.

Neogene strata of the Quiburis Formation in the San Pedro trough, and of roughly correlative upland gravel blankets, lap unconformably across the eroded edges of the older beds. The most extensive tilted sequences dip moderately ENE in homoclines that are separated by multiple normal faults, with variable westerly dips, into which the sedimentary homoclines abut downdip (Fig. 42, C-C', D-D'). At Star Flat, however, steeply dipping mid-Tertiary volcanic and sedimentary strata are truncated downdip at shallow depth by the subhorizontal Star Flat fault, inferred to be an updip segment of the detachment system that delineates the Catalina core complex. Basal unconformities where homoclines of mid-Tertiary strata rest depositionally upon Precambrian basement rocks are exposed locally, but are mostly concealed beneath Neogene cover or offset by local antithetic faults.

Structural relations. Tilted Precambrian and Paleozoic strata exposed near the mouth of Putnam Wash (Fig. 46), where they are cut by a tilted Laramide thrust, mark the flank of a tilt-block analogous to those exposed farther northwest in the Tortilla Mountains. The tilt-block was hinged downward along extensional fault structures now buried to the east beneath the sedimentary cover of the San Pedro trough. Correlative strata exposed farther east along the steep front of the Galiuro Mountains are deformed locally by Laramide monoclinal flexures, but generally dip more gently. Tilted blocks of Precambrian basement rocks exposed farther west were largely stripped of their sedimentary cover before deposition of the homoclinal mid-Tertiary successions that rest unconformably upon them. The tilt-block exposed near the confluence of James and Dodson washes (Fig. 46), with a local remnant of pre-Tertiary sedimentary cover still preserved beneath the mid-Tertiary sequence, is continuous northward with the tilt-block along the eastern flank of the Tortilla Mountains (Fig. 40).

The Camp Grant fault (Fig. 48), which dips gently $\left(\sim 30^{\circ}\right)$ to the west, is interpreted to be the northern continuation of the San Manuel fault as exposed in the Black Hills (Hansen, 1983). The continuity of the surface trace of the combined structure is broken by offset along the younger Cowhead Well fault (Fig. 46). Krieger (1974e) concluded that the Camp Grant fault was offset

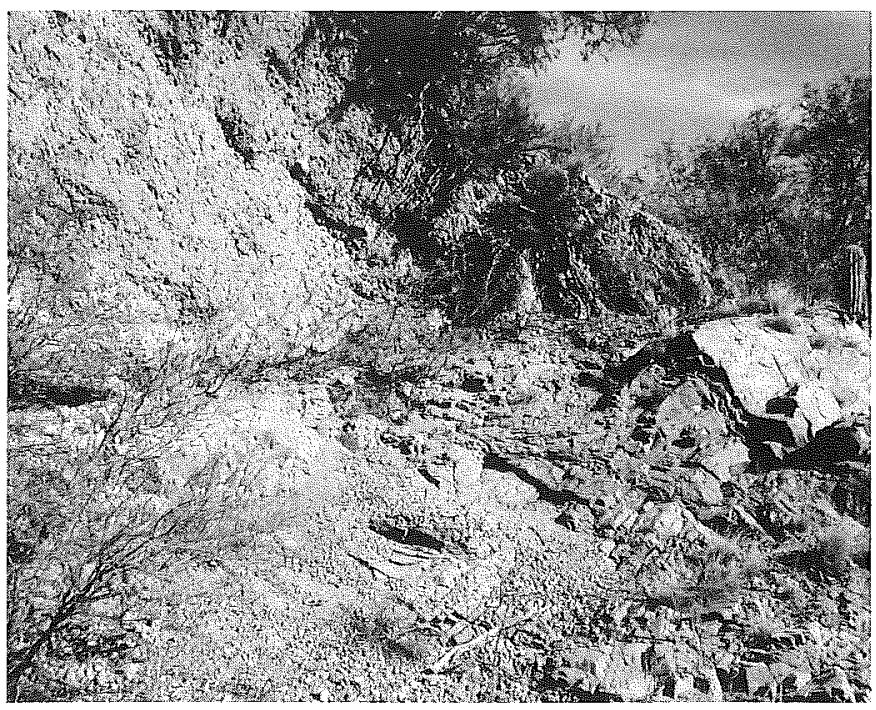

Figure 48. Exposure of Camp Grant fault inclined gently to left (west) along Camp Grant Wash. Conglomeratic beds of lower Miocene San Manuel Formation dipping moderately to right are truncated downdip against Precambrian basement by thin gouge seam along fault surface; note hammer in lower center for scale.

westward along an obscure transverse structure into the fault regarded here as the northern end of the Cowhead Well fault, but the Camp Grant fault is inferred here to persist on a more northerly trend until it passes beneath sedimentary cover near Elgin Wash along the flank of the San Pedro trough (Fig. 46). Still farther north, a continuation or splays of the Camp Grant fault may have been responsible for major extensional offsets beneath the San Pedro trough along the Gila River valley between the Tortilla and Dripping Spring Mountains. The northern and southern segments of the Cowhead Well fault are connected here through an area of poor exposure along a trend marked by strong dip discordance between mid-Tertiary sedimentary beds exposed east and west of the presumed fault trace (Fig. 46).

The subhorizontal Star Flat detachment fault, offset locally by steep normal faults (Fig. 46), underlies an isolated extensional klippe. Its relationship to other major structures within the Putnam Wash area is not clear from local field relations (Fig. 42, $\left.\mathrm{D}^{-} \mathrm{D}^{\prime}\right)$. Its geometry and stratigraphic relations are analogous, however, to the Cloudburst detachment fault of the Black Hills. As the latter fault is clearly offset by the San Manuel fault, the Star Flat fault is assumed to be older than the Camp Grant fault, which is in turn clearly older than the Cowhead Well fault that offsets it.

The dips of the three principal normal faults of the Putnam Wash area are thus inversely proportional to their age: oldest is the subhorizontal Star Flat fault, next is the Camp Grant fault dipping approximately $30^{\circ}$ to the west, and youngest is the Cowhead Well fault, which has poorly defined westerly dips varying from gentle on the north to steep on the south, but averaging perhaps $45^{\circ}$. Dihedral angles between the fault surfaces and 
homoclinal bedding in mid-Tertiary strata of the hanging walls are typically within the range 50 to $75^{\circ}$, implying that each of the faults was a moderately to steeply dipping structure where it intersected the mid-Tertiary land surface.

Each of the three faults may be a listric structure. If so, progressive erosional denudation of the area during its structural evolution can be invoked as explanation for the present exposure of more gently dipping segments of older faults and more steeply dipping segments of younger faults. On the other hand, progressive rotation of fault-bounded tilt-blocks through time may have bodily rotated the bounding normal faults as well, in which case shallower dips for older faults and steeper dips for younger faults can be understood as a simple function of their relative ages. Further study of the Cowhead Well fault is clearly indicated to ascertain whether its northward decrease in dip reflects different levels of erosion of a listric structure, progressively greater tilting farther north, or simply inherent variation in dip along strike.

Stratigraphic relations. Redbeds exposed near the confluence of Putnam and Camp Grant washes are assigned to the sedimentary upper member of the Cloudburst Formation by lithologic correlation with the type section in the Black Hills, but were regarded by Krieger (1974e) as "nongranitic red alluvial deposits" within the lower part of the overlying San Manuel Formation. Strata in the San Manuel Formation containing abundant granitic detritus were subdivided into several lithologic subunits by Krieger (1974e), who included parts of the exposures within the "Big Dome Formation." Strata of the Quiburis Formation along the San Pedro trough were initially included within the "Gila Conglomerate" (Krieger, 1968d) and were later assigned in part to the "Big Dome Formation" (Krieger, 1974e).

Lavas and breccias in the volcanic lower member of the Cloudburst Formation form part of the homocline exposed near Star Flat (Fig. 36G), but are not exposed elsewhere within the Putnam Wash area. Conglomeratic redbeds of the sedimentary upper member of the Cloudburst Formation are approximately 1,200 m thick at two localities: (1) near Star Flat (Fig. 36G), where they conformably overlie the volcanic lower member but the top of the unit is not exposed; and (2) in the homocline truncated downdip by the Camp Grant fault (Fig. 35E), where they concordantly underlie the San Manuel Formation but the base of the unit is not exposed (Fig. 46). Paleocurrent indicators in alluvial fan and braidplain facies along Camp Grant Wash record sediment transport to the WSW (Fig. 39E), presumably from sources in the adjacent tilt-block to the east flanking the San Pedro trough.

Clasts in Cloudburst conglomeratic strata at Star Flat are mainly mid-Tertiary volcanic rocks, which resemble the underlying Cloudburst volcanic rocks, and Precambrian granitic rocks of the Oracle/Ruin granite suite. Other clasts, chiefly of Pinal Schist and Precambrian sedimentary rocks of the Apache Group, are distinctly subordinate. Exposures of Cloudburst Formation along Camp Grant Wash, however, display a more mixed clast assemblage of Pinal Schist, Precambrian diabase, and both Precambrian and Paleozoic sedimentary rocks as well as mid-Tertiary volcanic rocks and a minor proportion of Precambrian granitic rocks. Although the two clast assemblages may partly reflect different stratigraphic positions, the comparable thicknesses of the two disparate successions suggest that differences in provenance were largely responsible for the strikingly different compositions. Perhaps the strata near Star Flat, where systematic paleocurrent data are unavailable, were derived from the backslope of a tiltblock lying to the west, rather than from the east.

The concordant contact between the Cloudburst and San Manuel Formations east of the Cowhead Well fault is marked by an abrupt transition from red coloration below to gray or buff beds above, with local development of caliche horizons indicative of hiatus or condensed section along the contact. North of Putnam Wash and west of the Cowhead Well fault, the San Manuel Formation wholly oversteps the Cloudburst Formation to rest directly on Precambrian basement rocks near Antelope Peak. Overlap of the Cloudburst Formation by the San Manuel Formation along a buried angular unconformity is inferred in the subsurface (Fig. 42, D-D ${ }^{\prime}$ ). Preserved exposures of the two formations leave open the question of whether the San Manuel Formation ever covered the Cloudburst Formation where the latter is exposed near Star Flat, but little erosional debris from the volcanic lower member of the Cloudburst Formation occurs within the San Manuel Formation, which is composed dominantly of granitic detritus. At the base of the San Manuel Formation between Bloodsucker and Palmer washes (Fig. 46), a lower Miocene mafic lava exposed directly above Precambrian basement of the Oracle/Ruin granite suite has yielded a K-Ar age of $22 \mathrm{Ma}$ (Dickinson and Shafiqullah, 1989), the only local age control for the mid-Tertiary succession within the Putnam Wash area.

The San Manuel Formation is composed dominantly of alluvial fan and braidplain facies, although a poorly defined, finer-grained interval of horizontally laminated sandstone occurs in the homocline west of the Cowhead Well fault. Conglomerate clasts were derived dominantly from the Precambrian Oracle/ Ruin granite suite so widely exposed within the Putnam Wash area, but also include fragments of Precambrian Pinal Schist, quartzite and limestone derived from Precambrian and Paleozoic sedimentary units that locally overlie the Precambrian basement, and minor amounts of varied mid-Tertiary volcanic rocks. Sparse paleocurrent indicators record generally southeasterly paleoflow for exposures west of the Cowhead Well fault and generally southwesterly paleoflow for exposures east of the Cowhead Well fault. This paleocurrent pattern suggests infilling of local halfgraben basins by dominantly transverse paleoflow from sources in bounding tilt-blocks, but the sandy interval within the formation may reflect deposition by axial streams flowing longitudinally. A gravity traverse along Putnam Wash detected the bedrock crest of a buried tilt-block at shallow depth along the upthrown side of the Cowhead Well fault (Hansen, 1983).

The gently dipping Quiburis Formation exposed along the flank of the San Pedro River valley rests unconformably on the San Manuel Formation and various pre-Tertiary units. Locally, 
basal parts of the unit are hinged into steep dips immediately adjacent to steep young normal faults with displacements antithetic to the flank of the San Pedro trough (Fig. 46). Only alluvial fan and braidplain facies composed of varied clasts derived from the nearby uplands to the southwest are exposed within the Putnam Wash area, but lacustrine facies are present farther east along the axis of the San Pedro trough. The dissected Neogene gravel cover blanketing uplands within the Putnam Wash area is presumably equivalent in age to some part of the Quiburis Formation, and is composed of debris derived locally from the flanks of the Black Mountains and more elevated parts of topographically subdued neighboring uplands.

\section{Black Hills area}

The Black Hills area west of Mammoth (Fig. 49) includes the San Manuel copper mine and was the locale for pioneering studies of mid-Tertiary stratigraphy and structure (Heindl, 1963; Creasey, 1965). Although unconformities between homoclines of mid-Tertiary strata and underlying pre-Tertiary rocks are exposed locally, gently dipping fault contacts where thick mid-Tertiary homoclinal sequences abut downdip against Precambrian granitic basement are more prominent features. Many early workers assumed that the gently dipping structures are thrusts. Subsurface documentation that the Kalamazoo orebody was offset from the San Manuel orebody along a low-angle normal fault (Lowell, 1968; Lowell and Guilbert, 1970) established that the structural style of mid-Tertiary deformation along the San Pedro trough was extensional.

Structural relations. Homoclinal successions of midTertiary strata that dip moderately to steeply ENE within the Black Hills are cut by two prominent low-angle normal faults of different age. The older of the two is the subhorizontal Cloudburst fault, which is interpreted as a segment of the detachment system that delineates the Catalina core complex. The Cloudburst detachment fault is cut and offset by the younger San Manuel fault, which dips gently $\left(25\right.$ to $\left.35^{\circ}\right) \mathrm{WSW}$ beneath the back flank of the Catalina core complex. The structural configuration of the intersection of these two major faults is complicated by additional offsets along a younger steep normal fault (Fig. 49). Strongly tilted mid-Tertiary strata and the low-angle normal faults that offset them are overlain unconformably by gently dipping Neogene basin fill of the Quiburis Formation, which onlaps the eastern flank of the Black Hills. Generally correlative but undated Neogene upland gravel deposits that mantle much of the drainage of Camp Grant Wash onlap the western flank of the Black Hills. Homoclinal mid-Tertiary strata of the Black Hills rest depositionally upon Precambrian granitic rocks of the Oracle/Ruin granite suite near Oracle, located just southwest of the Black Hills.

The Cloudburst fault is inclined gently to the northeast (Fig. 42, E-E'). The Cloudburst Formation of the hanging wall or upper plate is tilted to rather uniform northeast dips $\left(35\right.$ to $\left.55^{\circ}\right)$, and the sense of its displacement relative to the Precambrian basement of the footwall or lower plate is updip with respect to the present attitude of the fault surface. Although the geometry of offset is thrust displacement in a formal descriptive sense, the consistent juxtaposition of younger over older rocks across the fault argues persuasively for a normal sense of displacement instead. Backtilting of the whole detachment system as the Catalina core complex was arched upward is an attractive explanation for the present configuration of the structure. Outcrop relations imply a minimum offset of $5 \mathrm{~km}$ along the Cloudburst fault. Chloritic alteration in shattered Precambrian granitic rocks is prominent for about $1 \mathrm{~m}$ below the fault surface, which is marked by 1 to $2.5 \mathrm{~cm}$ of flinty cataclasite derived from subjacent granite. Intense hematitic alteration is common in volcanic rocks of the Cloudburst Formation for 1 to $2.5 \mathrm{~m}$ above the fault.

Three small fensters of Precambrian granite, too small to depict on Figure 49 but bounded by segments of the Cloudburst fault, allow the subhorizontal attitude of the fault to be estimated closely. One occurs along Tucson Wash just below its confluence with Cloudburst Wash, and the other two occur along a south branch of Tar Wash in ground north of Cloudburst Wash (Creasey, 1965). Structure contours of the fault surface, reconstructed using these fensters and the surface trace of the fault as control, indicate an average dip of approximately $4^{\circ}$ to $N 70^{\circ}-75^{\circ} \mathrm{E}$.

Exposures of the Cloudburst Formation structurally above the Cloudburst fault are bounded on the south by the Turtle fault, dipping steeply $\left(\sim 65^{\circ}\right) \mathrm{NNW}$ (Fig. 49). The Turtle fault is truncated by the San Manuel fault and displays horizontal striations on its fault surface where well exposed in Tucson Wash. It is interpreted provisionally as a tear structure or sidewall ramp of the Cloudburst detachment system. An offset segment of the Turtle fault in the hanging wall of the San Manuel fault was evidently overlapped by a thin sequence of uppermost Cloudburst Formation lying concordantly beneath San Manuel Formation south of Tucson Wash (Fig. 49).

The $N 70^{\circ} \mathrm{E}$ strike of the Turtle fault is subparallel to the strike of mylonitic lineation in mid-Tertiary tectonites exposed beneath the main Catalina detachment fault along the southwest

Figure 49. Geologic sketch map of Black Hills area (see Fig. 34 for location) between Oracle and Mammoth; CBW, Cloudburst Wash. Key faults: CBf, Cloudburst fault (detachment fault beneath Cloudburst or Tar Wash allochthon); Tf, Turtle fault (side ramp structure flanking Cloudburst allochthon); Cf/Mf, Cholla or Mammoth fault (basin-range structure). Modified after Heindl (1963), Creasey $(1965,1967)$, Weibel (1981), and Hansen (1983). See Figure 36 for columnar sections of mid-Tertiary and younger strata exposed along Tucson (column $\mathrm{H}$ ) and Cottonwood (column I) washes. Legend: 1, Precambrian basement; 2, intrusive Laramide porphyry; 3, volcanic lower member (Tcv) of Cloudburst Formation; 4, sedimentary upper member (Tcs) of Cloudburst Formation; 5, mid-Tertiary rhyolite and rhyolitic breccia bodies (which cut Cloudburst Formation but not San Manuel Formation); 6, San Manuel Formation (Tsm); 7, Quiburis Formation (Tqs) together with overlying terrace and pediment gravels; 8, Quaternary alluvium (Qal) along floodplain of San Pedro River. Internal contact within San Manuel Formation separates Kannally (k) and Tucson Wash (t) Members, which are in part facies equivalents. Asterisks (*) denote subsurface positions of San Manuel (SM) and Kalamazoo (KM) porphyry copper orebodies (SM in the footwall of the San Manuel fault and KM in the hanging wall). 


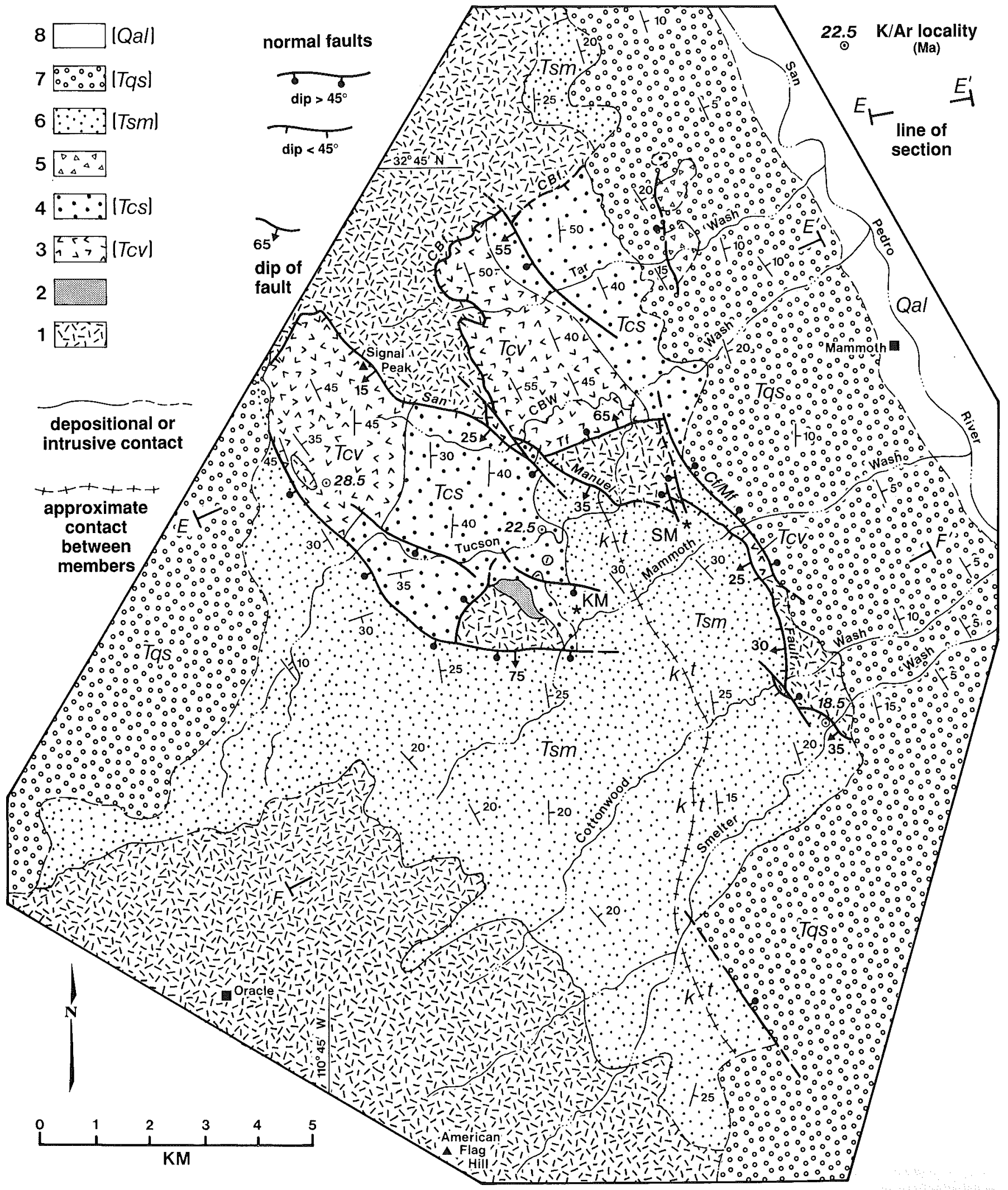


flank of the Catalina core complex. In ground lying north of the trend of the Turtle fault, segments of the detachment system are preserved as the Cloudburst and Star Flat (Fig. 46) allochthons. To the south of the Turtle fault, erosion apparently removed all remnants of the detachment system on the northeast flank of the Santa Catalina Mountains prior to Miocene deposition of the San Manuel Formation. The approximate alignment of the Turtle fault with the Guild Wash fault, bounding the northwest flank of the Tortolita Mountains, suggests that the two structures may jointly mark the southeast boundary of a subregional trough in the detachment system within which lie the Guild Wash, Star Flat, and Cloudburst allochthons (Fig. 13).

The trace of the San Manuel fault, offset locally by younger and steeper normal faults of modest displacement, traverses the Black Hills from northwest to southeast (Fig. 49). Normal slip of approximately $2.5 \mathrm{~km}$ almost directly downdip, to $S 50^{\circ}-55^{\circ} \mathrm{W}$, is well defined by subsurface offset of the Kalamazoo and San Manuel orebodies, which have been delineated by exploration drilling (Lowell, 1968; Lowell and Guilbert, 1970). Homoclinal dips in the San Manuel Formation in the hanging wall of the San Manuel fault are uniformly 20 to $30^{\circ}$, providing no evidence for either progressive tilting or rollover effects.

Steep normal faults that trend NNW cut the Quiburis Formation as well as older units in the Black Hills, and display offsets both synthetic and antithetic to the topographic flank of the San Pedro trough. The largest offset of 200 to $250 \mathrm{~m}$ occurs across the Cholla (Heindl, 1963) or Mammoth (Creasey, 1965, 1967) fault exposed along the eastern flank of the Black Hills southwest of Mammoth (Fig. 49). A comparable offset of 200 to $250 \mathrm{~m}$, but in the opposite sense (Heindl, 1963), occurs across an analogous fault that crosses Copper Creek and separates the Sombrero Butte block east of Mammoth from the main mass of the Galiuro Mountains beyond the San Pedro trough (Figs. 1 and 2).

Alternate fault geometry. Typical dihedral angles of 40 to $60^{\circ}$ between the surfaces of the Cloudburst and San Manuel faults and bedding planes in the homoclines of mid-Tertiary strata that form their hanging walls imply that both structures dipped at comparable angles near the ground surface during initial offset of mid-Tertiary sequences. The gentler present dips of exposed segments of both faults may reflect the inherent geometry of listric structures whose steeper headwalls have been removed by erosion. Alternately, each may have been a roughly planar fault of steep to moderate dip when active, and progressive rotation of Black Hills tilt-blocks may account for their present attitudes. The two alternate hypotheses imply different styles of extensional deformation (Fig. 16).

If the interpretation of listric geometry is accepted, the Cloudburst fault can be viewed as an updip continuation of the Catalina detachment fault. In this view, the Cloudburst segment of the detachment system was the structural link that connected the deep-seated Catalina segment to a steep headwall structure along the Galiuro range front at the flank of the San Pedro trough. Rotation of mid-Tertiary strata into homoclines abutting downdip into the detachment fault occurred as translation along listric structures carried the beds from the steep headwall of the detachment system downward along the surface of a gently dipping detachment fault spanning the full width of the Catalina core complex (Fig. 16A).

If the interpretation that normal faults rotated bodily together with intervening tilt-blocks is accepted, the structural evolution of the Catalina core complex and San Pedro trough must be regarded in another way. The alternate picture emerges if all normal faults in the Black Hills were initiated at $60^{\circ}$ dips and movement on each locked up when the structure had rotated to a dip of $30^{\circ}$. Restoration of the San Manuel fault from its present dip of approximately $30^{\circ}$ to a postulated initial dip of $60^{\circ}$ would rotate the nearly horizontal Cloudburst fault to a dip near $30^{\circ}$. Additional restoration of the Cloudburst fault to an initial dip of $60^{\circ}$ could be achieved by reversing the effects of a single preceding rotational episode of analogous character. As the long axis of the offset porphyry copper orebody in the Black Hills now plunges approximately $20^{\circ}$ to the southwest (Lowell, 1968; Lowell and Guilbert, 1970), reversal of two such rotational episodes would restore it to a subvertical position (alternatively, some fraction of its plunge might be explained by appeal to Laramide deformation). If this rotational model is valid for structures in the Black Hills, then the Cloudburst and Catalina faults may represent different generations of detachment surfaces (Fig. 16B).

The nature of the structural relationship between the Cloudburst, Star Flat, and Guild Wash allochthons (Fig. 13) is interpreted quite differently from the two alternate standpoints. If the notion of a coherent subregional detachment structure of listric character is valid, the three allochthons were presumably rotated individually downward against a common subhorizontal detachment surface by coordinate movement on branching splay faults, which have since been removed by erosion except within exposures of the Guild Wash allochthon. If the allochthons are floored structurally, however, by separate subparallel members of a family of rotational planar faults, then superposed younger faults masked by Neogene cover must exist within Precambrian basement rocks that intervene between present exposures of the three allochthons.

The two points of view can possibly be reconciled by assuming that the Cloudburst fault formed part of a steeply dipping headwall fault complex lying updip from a more gently dipping master detachment. Dislocation and rotation of the headwall fault complex might have occurred following the development of secondary breakaway zones without causing rotation of the master detachment surface at sites farther away from the initial breakaway zone. If so, the Star Flat fault of the nearby Putnam Wash area (Fig. 46) may have undergone a similar but diachronous structural history as excisement fault strands of the breakaway zone migrated westward.

Cloudburst Formation. The volcanic lower member of the Cloudburst Formation is cut by numerous dikes and plugs of porphyritic rhyolite and rhyodacite in the Black Hills (Creasey, 1965, 1967). Flow-banding and autobrecciated layers oriented 
subparallel to stratification in the enclosing andesitic to latitic volcanic rocks suggest that some of the felsic intrusive bodies vented to merge with surficial domes and stubby flows intercalated within the volcanic pile.

One of the two principal outcrop belts of Cloudburst Formation in the Black Hills lies north of the Turtle fault in the footwall of the San Manuel fault and the other lies in the vicinity of Signal Peak in the hanging wall of the San Manuel fault (Fig. 49). Both outcrop belts form simple homoclinal sections truncated downdip by faults. The footwall homocline is truncated downdip against Precambrian granitic rocks by the subhorizontal Cloudburst fault, and its stratigraphic base is nowhere exposed. Southwest of Signal Peak, however, the other homocline rests depositionally upon Precambrian granitic rocks along the western flank of the Black Hills (Weibel, 1981; Hansen, 1983). The unconformity is marked by a red paleosol developed on underlying Precambrian basement of the Oracle/Ruin granite suite, and by the presence of angular pebbles and reworked grus of granitic rock fragments and phenocrystic feldspar grains in the basal $25 \mathrm{~m}$ of the overlying Cloudburst volcaniclastic strata. Within this stratigraphic interval, as much as half the debris in trough cross-stratified volcaniclastic beds is granitic detritus that occurs in pebble conglomerate layers and as thin stringers of granitewash grit.

In both homoclinal exposures, the volcanic lower member of the Cloudburst Formation is overlain gradationally by the sedimentary upper member (Fig. 36H). The latter unit, however, locally oversteps the volcanogenic rocks of the Cloudburst Formation to rest directly on Precambrian and Laramide granitic rocks (Fig. 49). Exposures southeast of Signal Peak near Tucson Wash indicate that syndepositional faulting, active during accumulation of the sedimentary upper member of the Cloudburst Formation, allowed erosion to expose Precambrian basement intruded by Laramide porphyry at the crest of a local fault block. As sedimentation continued, the fault block was onlapped by a horizon near the top of the Cloudburst Formation. An early Miocene K-Ar age $(\sim 22.5 \mathrm{Ma})$ for sanidine separated from a rhyolitic clast in a volcaniclastic bed within $25 \mathrm{~m}$ of the base of the overlying San Manuel Formation shows that burial of the fault block occurred near the Oligocene-Miocene time boundary (Weibel, 1981; Dickinson and Shafiqullah, 1989). The presence of local megabreccia bodies within the sedimentary upper member of the Cloudburst Formation also argues that syndepositional faulting was underway nearby during Cloudburst sedimentation. Blocks derived from the Oracle/Ruin granite suite of the local Precambrian basement are most abundant in Cloudburst megabreccias of the Black Hills (Creasey, 1965, 1967).

Clast-supported streamflood deposits that display clast imbrication are more abundant than matrix-supported debris-flow deposits in alluvial fan and braidplain facies of the Cloudburst Formation. Paleocurrent indicators document consistently eastward paleoflow directions with an ESE vector mean (Fig. 39F). Deposition may have built a bajada surface that sloped eastward toward lowlands where outflow sheets of ignimbrite in the Gali-

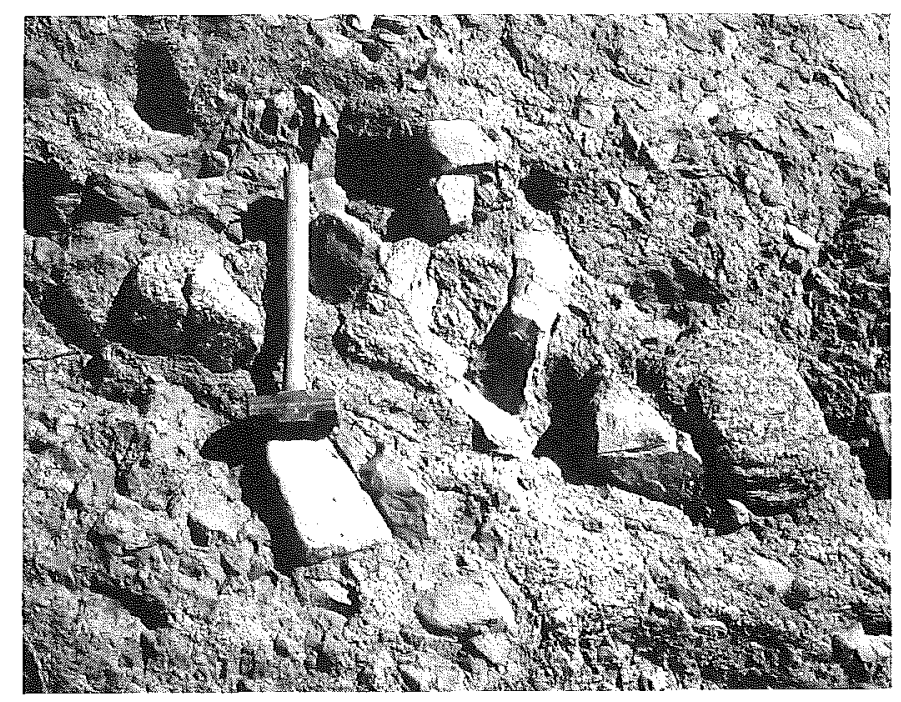

Figure 50. Mixed granitic (granular and speckled) and volcanic (uniformly pale or dark) clasts in alluvial fan and braidplain facies of the sedimentary upper member of the Cloudburst Formation exposed at the narrows of Tucson Wash in Black Hills near Mammoth (hammer for scale).

uro Volcanics ponded in a paleovalley along the present site of the Galiuro Mountains. Clast imbrication $(n=20)$ in volcaniclastic strata of the partly correlative Apsey Conglomerate Member of the Galiuro Volcanics at Table Mountain, located on the Galiuro crest across the San Pedro River valley from the Black Hills, defines northwestward paleoflow (vector mean of $\mathrm{N}^{\circ} 3^{\circ} \mathrm{W}$ ) that may reflect the trend of the paleovalley. The Apsey Conglomerate Member directly overlies the main ignimbrite sheets of the Galiuro Volcanics.

Clasts in the sedimentary upper member of the Cloudburst Formation are mainly Precambrian granitic rock of the Oracle/ Ruin granite suite and intermediate volcanic rocks lithologically similar to those in the underlying volcanic lower member of the Cloudburst Formation (Fig. 50). Subordinate sources included Precambrian and Paleozoic sedimentary sequences (yielding mainly quartzite clasts), Precambrian diabase, and Laramide porphyry. Deposition evidently accompanied erosional stripping of mid-Tertiary and pre-Tertiary cover from granitic basement in uplands lying just north of the Santa Catalina Mountains, and feeder drainages may have tapped parts of the mountain mass itself.

Volcanism continued locally during deposition of the sedimentary upper member of the Cloudburst Formation. Near Tar Wash (Fig. 49), for example, a volcanic dome of flow-banded sugary rhyolite or rhyodacite containing zones of autoclastic volcanic breccia also contains inclusions of indurated and baked conglomerate clearly derived from the sedimentary upper member of the Cloudburst Formation. This felsic igneous body is lithologically similar to older domes and plugs exposed farther west within the lower volcanic member of the Cloudburst Formation. A feeder dike of similar lithology cutting Precambrian 
basement $10 \mathrm{~km}$ to the north near the mouth of Putnam Wash has yielded an early Miocene ( $\sim 23 \mathrm{Ma}) \mathrm{K}$-Ar age (Dickinson and Shafiqullah, 1989).

San Manuel Formation. The San Manuel Formation rests concordantly on the sedimentary upper member of the Cloudburst Formation near Tucson Wash (Fig. 49), but lacks any cross-cutting felsic dikes or plugs. Previous workers concluded that the contact was an angular unconformity (Heindl, 1963; Creasey, 1965, 1967), but the contact interpreted as an unconformity was later shown to be a fault that juxtaposes contrasting stratal successions within the sedimentary upper member of the Cloudburst Formation (Weibel, 1981). The supposed "local basal conglomerate" of the San Manuel Formation thus proves to be offset Cloudburst strata. At the actual formational contact, however, recent quarry cuts reveal scour of Cloudburst redbeds to a depth of 2.5 to $5 \mathrm{~m}$ prior to deposition of the overlying gray strata of the San Manuel Formation.

The San Manuel Formation of the Black Hills (Figs. $36 \mathrm{H}$ and I) is subdivided locally into the lower Kannally Member and the upper Tucson Wash Member (Heindl, 1963). Although both are composed of alluvial fan and braidplain facies, they represent two successive and partly interfingering depositional systems. Paleocurrent indicators in the Kannally Member document eastward paleoflow, with an ESE vector mean (Fig. 39G), whereas paleoflow during deposition of the succeeding Tucson Wash Member was westward, with a vector mean nearly due southwest (Fig. 39H). Clasts in the Kannally Member were derived predominantly from Precambrian basement of the Oracle/Ruin granite suite, whereas the Tucson Wash Member contains abundant clasts of mid-Tertiary volcanic and volcaniclastic rocks, both intermediate and felsic. The Kannally Member records the growth of alluvial fans and braidplain aprons derived from uplifted basement along the backtilted flank of the Catalina core complex and associated uplands lying farther north. By contrast, the Tucson Wash Member records the recycling of mid-Tertiary cover stripped from fault scarps and fault blocks now buried beneath the San Pedro trough. Interfingering of granite-clast and volcanicclast beds near the contact between the Kannally and Tucson Wash Members, and the presence of some beds of intermediate or mixed lithology, suggests that the younger depositional system prograded gradually across the older one.

Although the clasts of volcanic rock within the Tucson Wash Member could have been derived from both the Cloudburst Formation exposed locally within the Black Hills and from the Galiuro Volcanics exposed across the San Pedro trough, some large blocks of volcaniclastic sedimentary breccia imbedded in local debris-flow deposits of the Tucson Wash Member are diagnostic of a nearby Cloudburst provenance (Fig. 51). Their occurrence argues for continued syndepositional faulting within the Black Hills throughout the time of San Manuel sedimentation. Moreover, the Tucson Wash Member oversteps the San Manuel fault, but the Kannally Member was deposited only west of the fault. The local occurrence of diverse megabreccia bodies within the San Manuel Formation of the Black Hills reflects the exis-

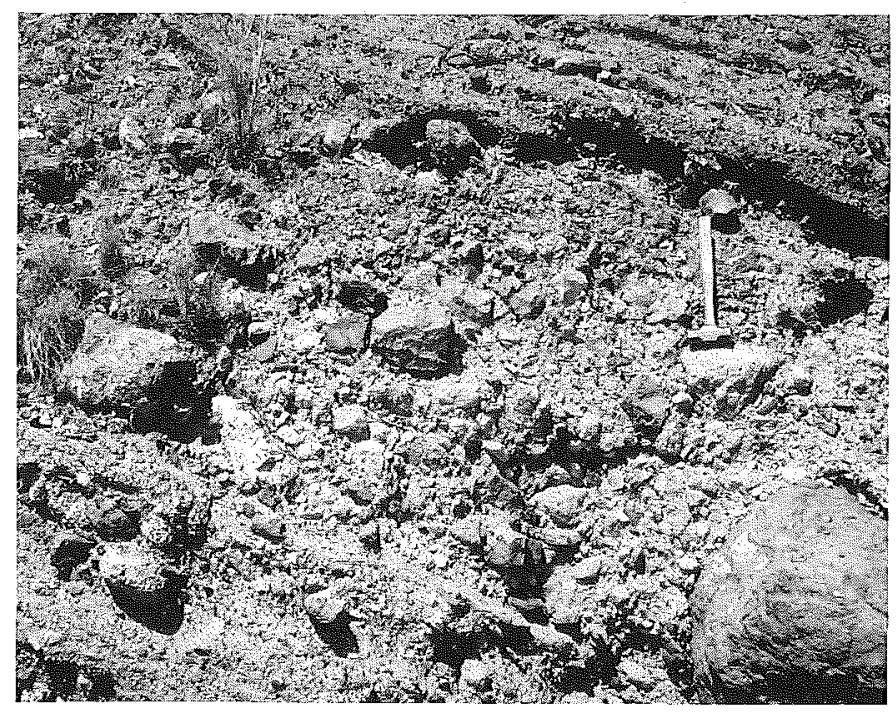

Figure 51. Outcrop of Tucson Wash Member of San Manuel Formation along Tucson Wash in Black Hills near Mammoth; large dark clasts (lower right and far left) reworked from nearby exposures of volcanic lower member of Cloudburst Formation (hammer for scale).

tence of abrupt local relief. Blocks of Precambrian diabase, limestone, and quartzose are most abundant in San Manuel megabreccias of the Black Hills (Creasey, 1965, 1967).

The thickest exposed homocline of San Manuel Formation along Cottonwood Wash reaches an apparent maximum thickness of 2,000 m (Fig. 42, F-F'), although multiple repetition of the section across mesoscopic faults visible only at outcrop scale in nearby roadcuts may reduce the actual stratigraphic section present to the order of 1,200 to $1,500 \mathrm{~m}$ (Hansen, 1983). The unconformity at the base of the sequence laps onto basement along the flank of the Santa Catalina Mountains, but the top of the section is cut off at the San Manuel fault. An early Miocene fission-track (apatite) age of $18.5( \pm 3.5) \mathrm{Ma}$ was obtained for a tuff bed exposed in Smelter Wash no more than 25 to $50 \mathrm{~m}$ below the highest horizon present in the San Manuel Formation of the Black Hills (Dickinson and Shafiqullah, 1989). This locality confirms that San Manuel deposition did not persist past mid-Miocene $(\sim 15 \mathrm{Ma})$ time.

Within the Galiuro Mountains, the Apsey Conglomerate Member of the Galiuro Volcanics (Fig. 36J) is equivalent in age to some upper part of the Cloudburst Formation, but no strata correlative with the San Manuel Formation are present within the mountain block. San Manuel deposition was evidently restricted to fault-bounded basins located entirely west of the range front. East of the Galiuro Mountains, Miocene strata of the Hell Hole Conglomerate (Fig. 36J), at least partly equivalent in age to the San Manuel Formation (Dickinson and Shafiqullah, 1989), are nearly flat-lying and rest depositionally on eroded Galiuro Volcanics along a buttress unconformity delimiting the erosional eastern flank of the mountain block (Walsh, 1989). Tilted and faulted older horizons of basin fill overlying Galiuro Volcanics 
north of Allen flat (Fig. 38, AF), located near the southeast edge of the study area, may also be correlative with the San Manuel Formation. The tilted homoclines of San Manuel beds exposed along the trend of the San Pedro trough have no known counterparts east of the Galiuro Mountains.

Quiburis Formation. Strata of the Quiburis Formation that lap onto the eastern flank of the Black Hills are coarse fluvial deposits of alluvial fan and braidplain facies. Immediately to the east of the floodplain of the San Pedro River, however, lacustrine and associated facies are dominant in exposures of the Quiburis Formation. Detailed study of Quiburis strata east of the Black Hills disclosed a complex facies assemblage: (1) conglomeratic beds deposited as alluvial fans and fan deltas, (2) sandy fan toe or sandflat and silty mudflat deposits of lake margins, (3) green lacustrine siltstone with laminated limestone/diatomite intervals deposited during perennial lake phases, and (4) gypsum and gypsiferous mudstone deposited during ephemeral lake phases and on saline mudflats fringing varied lacustrine environments (Utley, 1980). East of Mammoth (Fig. 49), continuous exposures of Quiburis Formation extending along Copper Creek for $10 \mathrm{~km}$ from the San Pedro River to the range front of the Galiuro Mountains afford a magnificent unfaulted outcrop display of the lateral and upward facies transition from lakebeds deposited along the axis of the San Pedro trough to piedmont fan facies along the range front.

\section{Soza-Teran area}

The Soza-Teran area (Fig. 52), centered on Cascabel at the mouth of Hot Springs Canyon, extends from the edge of the Catalina core complex along the northeast flank of the Rincon Mountains across the San Pedro River valley to the southern end of the Galiuro Mountains (Fig. 34). Multiple homoclines of midTertiary strata are exposed locally in tilt-blocks overlain unconformably by nearly flat-lying basin fill of the Quiburis Formation, which underlies much of the central part of the area. The detachment fault bounding mylonitic core rocks is exposed intermittently along the southwest edge of the area where it is offset locally by younger normal faults. Low-angle normal faults farther east along the southwest flank of the Galiuro Mountains (Dickinson and others, 1987a) are located near the inferred headwall of the mid-Tertiary detachment system. Steep basinrange normal faults striking NNW offset Quiburis Formation as well as older units within the San Pedro trough.

Structural relations. The backtilted San Pedro detachment fault (Lingrey, 1982) of the Catalina detachment system is inclined eastward at gentle to moderate dips $\left(25\right.$ to $\left.45^{\circ}\right)$. The apparent sense of displacement of the upper plate over the lower plate is updip in terms of the present attitude of the fault surface. The homocline of type Mineta Formation dips moderately to steeply (35 to $75^{\circ}$ ) ENE and rests nonconformably on Precambrian basement rocks in the upper plate of the San Pedro detachment fault. For much of its trend, the homocline follows the course of Cañada Atravesada (Fig. 37L), a natural route of travel across a low drainage divide between aligned tributaries of Soza and Roble canyons (Fig. 52). The displaced segment of a Laramide thrust, an offset strand of the Palomas Wash thrust system, places the underlying basement rocks above strata of the Bisbee Group, which is also part of the upper plate of the detachment system.

Most previous mapping has shown the basal depositional contact of the type Mineta homocline as a steep normal fault (Thorman and Drewes, 1981; Lindgrey, 1982) but its unconformable nature is well exposed at several localities (Warner, 1982; Dickinson and Olivares, 1987). The basal nonconformity can be traced for approximately $10 \mathrm{~km}$ along strike. The San Pedro detachment fault truncates the homocline downdip in the subsurface. At Mineta Ridge near the complexly faulted northern end of the homoclinal outcrop belt, strata of the Mineta Formation and the overlying Galiuro Volcanics are offset by at least one low-angle normal fault, a subsidiary splay branching off the master detachment surface (Dickinson and Olivares, 1987). The northeast side of the exposed homocline is delimited by the Banco Ridge fault (Fig. 52), a steeply dipping (60 to $70^{\circ}$ ) normal fault that brings younger basin fill of the Quiburis Formation down against the Mineta Formation. Where displacement across the Banco Ridge fault is minimal, an angular $\left(\sim 75^{\circ}\right)$ unconformity is exposed locally between the Mineta and Quiburis Formations.

The location and nature of the extension of the San Pedro detachment fault beneath the basin fill of the San Pedro trough is uncertain. Several low-angle normal faults exposed along the flank of the Galiuro Mountains east of Cascabel dip beneath basin fill of the Quiburis Formation and project into the subsurface under the San Pedro River valley (Dickinson and others, 1987a). The most likely continuation of the main detachment surface beyond the San Pedro River is the subhorizontal Soza Mesa fault exposed near Hot Springs Canyon (Fig. 52), where it is inclined gently $\left(\sim 10^{\circ}\right)$ to the southwest and offsets the base of the Galiuro Volcanics by 2 to $4 \mathrm{~km}$ from exposures along the main range front of the Galiuro Mountains. The moderately dipping (35 to $40^{\circ}$ ) Teran Wash and Teran Basin faults (Fig. 52), which offset Mineta Formation and Galiuro Volcanics by 1 to 2 $\mathrm{km}$, may also be splays or strands of the San Pedro detachment fault (Grover, 1982, 1984), but are regarded here as somewhat younger structures analogous to the San Manuel fault farther north (Fig. 13).

As elsewhere within the study area, the present gentle to moderate dips of the group of normal faults exposed east of Cascabel may reflect either original listric character or tilting of once-steeper fault surfaces. If the dips of the group of faults were achieved by fault rotation, previously published cross sections (Dickinson and others, 1987a) indicate that restoration of the moderately dipping $\left(\sim 35^{\circ}\right)$ Teran Wash and Teran Basin faults to steep dips (of 60 to $70^{\circ}$ ) would steepen the Soza Mesa fault to a moderate dip (of 35 to $45^{\circ}$ ). As in the Black Hills, two successive rotational episodes (each of $\sim 30^{\circ}$ ), affecting the Soza Mesa and Teran Wash/Basin faults in sequence, could have produced the observed low fault dips. If so, however, heterogeneous defor- 


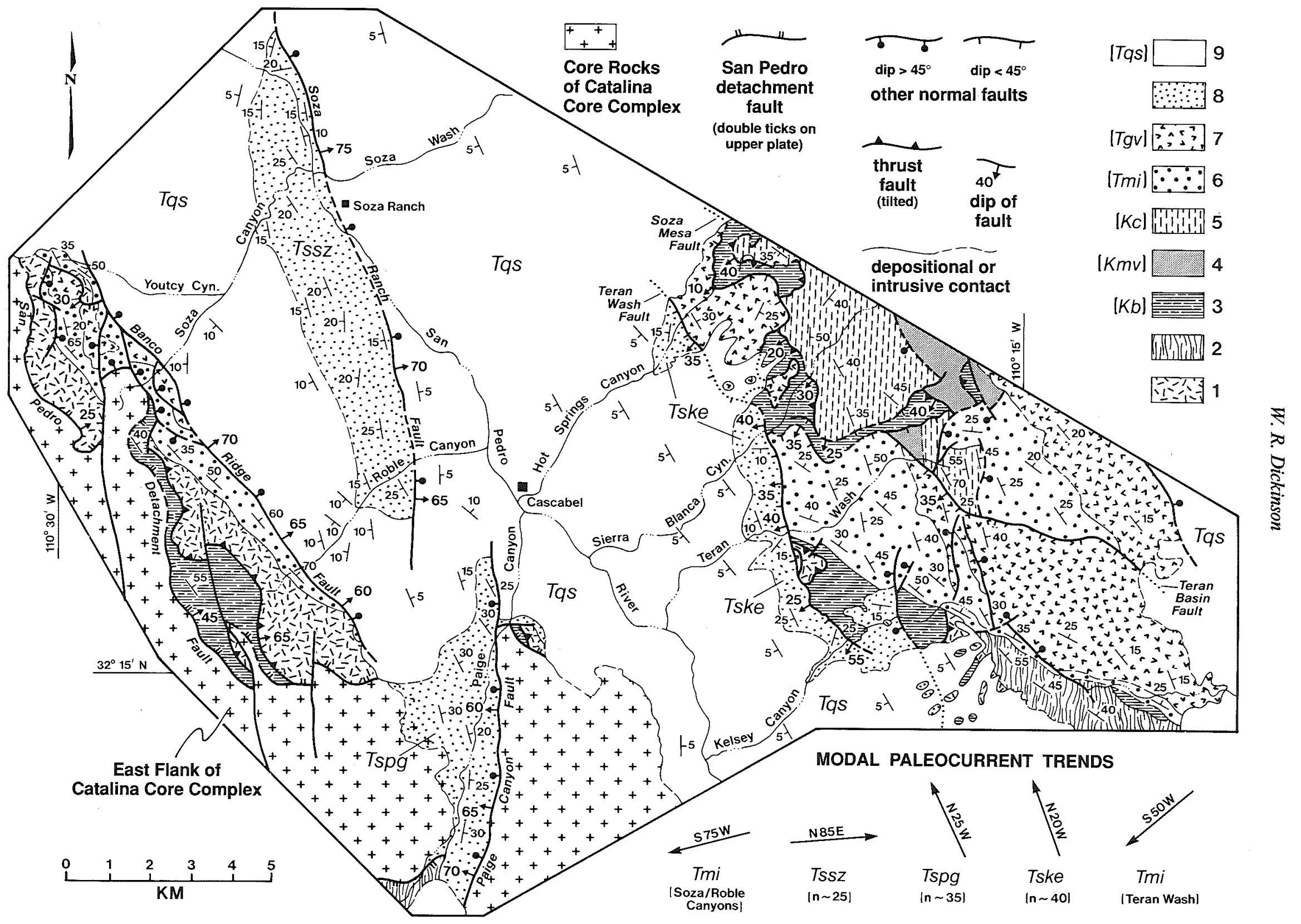


mation of tilt-blocks is required because current dips of the Soza Mesa $\left(10\right.$ to $\left.30^{\circ}\right)$ and Teran Wash $\left(25\right.$ to $\left.55^{\circ}\right)$ faults vary markedly along strike (Fig. 52). Moreover, the presence of upright rollover anticlines in strata of the San Manuel Formation in the downthrown block adjacent to the Teran Wash fault (Dickinson and others, 1987a) casts doubt on more than modest amounts of fault rotation, and directs attention instead to the likelihood of listric geometry.

The steeply dipping (60 to $75^{\circ}$ ) Paige Canyon and Soza Ranch faults, with opposed dips and offsets, delineate a young normal fault belt extending north-south through the central part of the Soza-Teran area (Fig. 52). An east-dipping homocline of San Manuel Formation rather typical of structural features within the study area occurs on the downthrown side of the Paige Canyon fault, but a distinctly atypical west-dipping homocline of San Manuel Formation occurs on the upthrown side of the Soza Ranch fault. The latter structure is isolated by surrounding basin fill, which masks its relationship to more typical structures of the San Pedro trough, but it evidently records a late episode of antithetic normal faulting that occurred after the mid-Tertiary detachment system of the Catalina core complex was dormant.

Mineta Formation. The Mineta Formation includes heterogeneous alluvial fan and braidplain facies (Figs. 53 and 54) that interfinger with varied lacustrine facies. Red coloration is characteristic of the alluvial deposits, but lacustrine strata are composed of dark gray to green mudstone and pale gray to white limestone and gypsum. In the type area, the discontinuous felsic ignimbrite resting upon Precambrian basement rocks at the base of the section has yielded a spurious $\mathrm{K}-\mathrm{Ar}$ age of $25 \mathrm{Ma}$ (Table 7), but is probably correlative with a similar ignimbrite at the base of the Pantano Formation near Cienega Gap, $25 \mathrm{~km}$ to the south (Fig. $37 \mathrm{~K}$ ), where reliable $\mathrm{K}-\mathrm{Ar}$ ages of $\sim 35 \mathrm{Ma}$ have been obtained (Dickinson and Shafiqullah, 1989). The lensoid nature of the ignimbrite reflects deposition on irregular paleotopography developed by Laramide erosion.

Three members of type Mineta Formation exposed along Cañada Atravesada (Fig. 37L) between Soza and Roble canyons display the following sedimentological features (Olivares, 1991):

Figure 52. Geologic sketch map of Soza-Teran area of San Pedro trough (see Fig. 34 for location). Modified after Thorman and Drewes (1981), Lingrey (1982), Dickinson (1986), Dickinson and Olivares (1987), and Dickinson and others (1987a). See Figure 37 for columnar sections of mid-Tertiary and younger strata exposed along Cañada Atravesada (column L) between upper Soza and Roble canyons, along lower Soza Canyon (column M), across Paige Canyon (column $\mathrm{N}$ ), and around Teran Wash (column $\mathrm{O}$ ) between Sierra Blanca and Kelsey canyons. Legend: 1, Precambrian basement; 2, Paleozoic strata; 3, Lower Cretaceous Bisbee Group (Kb); 4, Upper Cretaceous Muleshoe Volcanics $(\mathrm{Kmv})$; 5, Upper Cretaceous Cascabel Formation (Kc); 6, Mineta Formation (Tmi); 7, Galiuro Volcanics (Tgv); 8, San Manuel Formation (Tssz, volcaniclastic Soza Canyon facies; Tspg, metamorphiclastic Paige Canyon facies; Tske, plutoniclastic Kelsey Canyon facies); 9, Quiburis Formation (Tqs), together with overlying terrace and pediment gravels, as well as Quaternary alluvium present locally along San Pedro River and its major tributaries. Paleocurrents after Figure 39, Grover (1982), and Olivares (1991).

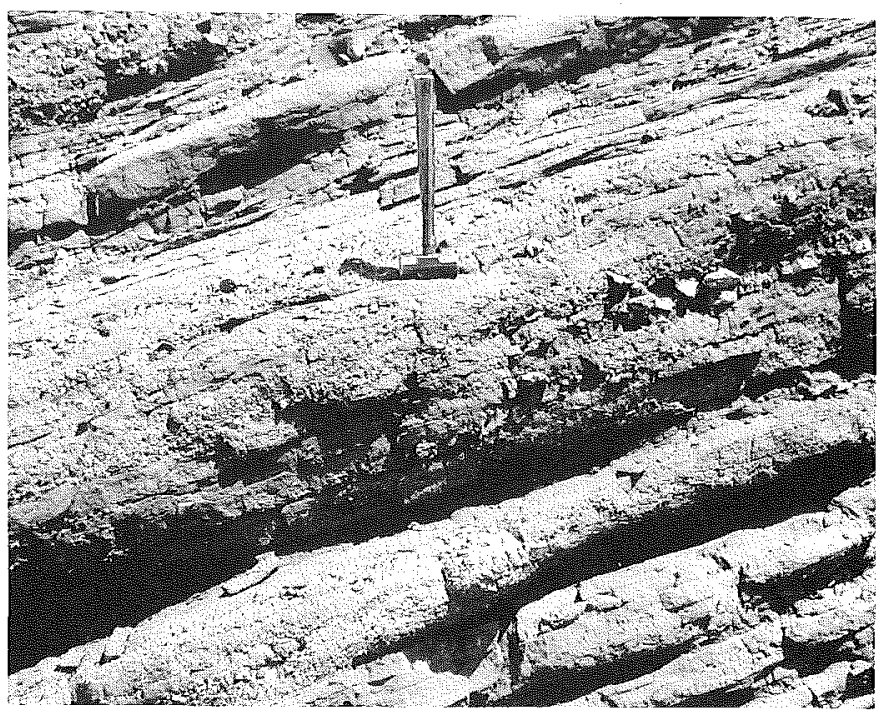

Figure 53. Outcrop of intercalated sandy conglomerate and conglomeratic sandstone in alluvial fan and braidplain facies of Mineta Formation exposed along Teran Wash (hammer for scale).

(1) The lower conglomeratic member of alluvial fan and braidplain facies 100 to $250 \mathrm{~m}$ thick includes (a) a lower monomictic submember composed almost exclusively of clasts of Precambrian granitic rock, derived from subjacent basement of Johnny Lyon granodiorite suite, set in a matrix of arkosic sand; and (b) an upper polymictic submember containing clasts of mid-Tertiary volcanic rocks (20 percent), Paleozoic carbonate rocks (20 percent), Bisbee sandstone (10 percent), and Pinal Schist (5 percent) as well as Johnny Lyon granitic rocks (45 percent). The two submembers are of comparable thickness, except that the lower submember thickens northward and the upper submember is absent in northernmost outcrops between Youtcy

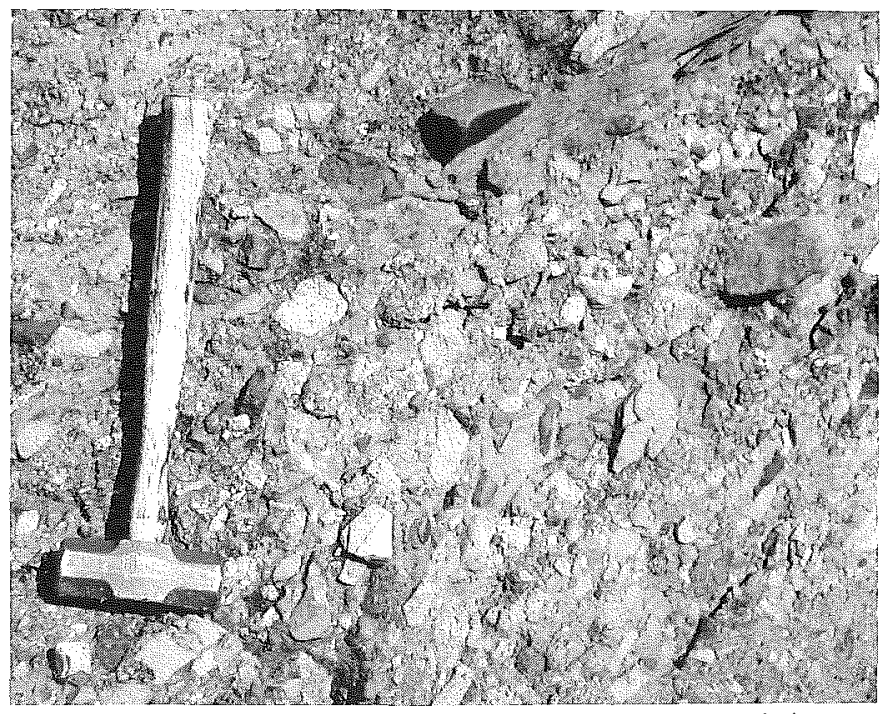

Figure 54. Typical heterogeneous clast assemblage in polymictic conglomerate of Mineta Formation exposed along Teran Wash (hammer for scale). 
and Soza Canyons. The upper conglomeratic submember grades upward into laminated and trough cross-bedded sandstone just beneath the contact with the overlying limestone-bearing member.

(2) The middle limestone-bearing member consists of distal fan, sandflat, and marginal lacustrine deposits that reach an aggregate thickness of nearly $150 \mathrm{~m}$ north of the Soza/Roble drainage divide, but are absent to the south. Littoral bioherms of oncolitic algal limestone, which forms resistant beds as much as 1 $\mathrm{m}$ thick individually, are intercalated within a sequence of horizontally laminated and trough cross-bedded lithic arkose and pebble conglomerate thought to have been deposited along the lacustrine fringe of a fan or braid delta.

(3) The upper mudstone member includes varied lacustrine strata 100 to $250 \mathrm{~m}$ thick, and is thickest to the south where the middle limestone-bearing member is absent. Intertonguing of the two members near the Soza/Roble drainage divide shows that they are in part facies equivalents. Massive dark gray mudstone is the dominant lithology of the upper mudstone member, but subordinate intercalated beds include micritic limestone, rippled or graded sandstone, and laminated gypsum. Gypsum occurs in beds as much as $1 \mathrm{~m}$ thick individually within an interval $25 \mathrm{~m}$ thick south of the Soza/Roble drainage divide, but is absent to the north.

The distribution of lithofacies within the type Mineta Formation indicates that the homoclinal exposures obliquely transect a facies transition between dominantly fluvial and shoreline facies to the north and more open lacustrine or playa facies to the south. Multiple interfingering facies boundaries of similar type occur within the areally more extensive outcrops of Mineta Formation east of the San Pedro River (Grover, 1982, 1984). Except, however, for basal conglomerate ( $\sim 10 \mathrm{~m}$ thick) rich in clasts derived from the Johnny Lyon granodiorite suite, the gravel clasts east of the San Pedro River are Bisbee sandstone (60 percent), Paleozoic limestone ( 25 percent), mid-Tertiary volcanic rocks ( 10 percent), and Pinal Schist (5 percent). Lacustrine limestone beds include stromatolitic cryptalgal laminites as well as fragmental oncolitebearing layers, but gypsum-bearing intervals are sparse though locally prominent. Repetitive transgressive or retrogradational cycles, each 200 to $250 \mathrm{~m}$ thick, grade upward from alluvial fan to braidplain to sandflat to nearshore lacustrine to offshore lacustrine facies (Grover, 1984).

Paleocurrent indicators in the Mineta Formation record westward paleoflow directions, with vector means nearly due west in exposures west of the San Pedro River and toward the southwest in exposures east of the San Pedro River (Figs. 39L and $\mathrm{M}$ ). The coarseness of alluvial fan and braidplain facies in all exposures suggests that deposition occurred within multiple halfgraben basins bounded by local fault scarps now largely hidden beneath younger sedimentary and volcanic cover. Sediment transport across west-facing fault scarps from nearby sources in adjacent uplifted blocks is implied by the observed paleocurrent pattern, coupled with the prevailing structural grain and sense of homoclinal tilting within the San Pedro trough. Wide scatter in paleocurrent directions suggests, however, that longitudinal transport systems developed locally within some parts of the half-graben basins.

San Manuel Formation. Strata of the San Manuel Formation in the southern San Pedro trough have been designated in the past by informal local names (Figs. 37M through $\mathrm{O}$ ). Correlation with the San Manuel Formation of the Black Hills is based on general stratigraphic position, overall lithologic similarity, comparable degree of induration, and analogous amounts of structural tilt. Attempts to date intercalated impure tuff beds directly have so far failed. The San Manuel Formation is exposed as three separate homoclines within the Soza-Teran area and contains a different clast assemblage in each area of exposure:

(1) Clasts in the volcaniclastic Soza Canyon facies, exposed near the San Pedro River adjacent to the Soza Ranch fault (Fig. 52), are dominantly varicolored black, gray, brown, red, green, and buff volcanic rocks of dominantly andesitic to latitic composition derived mainly from the Galiuro Volcanics. Eastward paleocurrents (Fig. 39K) imply a provenance in the vicinity of present exposures of the type Mineta Formation and overlying erosional remnants of Galiuro Volcanics along the flank of the Rincon Mountains. Subordinate clasts include contributions from Precambrian granitic rocks of both the Oracle/Ruin granite suite and the Johnny Lyon granodiorite suite, as well as limestone and quartzite reworked from Paleozoic cover. A debris-avalanche megabreccia body $\sim 25 \mathrm{~m}$ thick occurs $\sim 100 \mathrm{~m}$ below the upper contact of the San Manuel Formation with the overlying Quiburis Formation along Soza Canyon, and is composed entirely of shattered Galiuro Volcanics. A clast from the megabreccia yielded a K-Ar age of 25 to $26 \mathrm{Ma}$ (Dickinson and Shafiqullah, 1989).

(2) Clasts in the metamorphiclastic Paige Canyon facies, exposed along Paige Canyon adjacent to the Paige Canyon fault (Fig. 52), are dominantly tectonites derived from metamorphic rocks similar to those now exposed in the Little Rincon Mountains, which flank and lie south of preserved outcrops. Paleoflow during sedimentation was dominantly to the NNW (Fig. 39J), longitudinal with respect to the Paige Canyon half-graben but in a direction appropriate for tapping nearby exposures of metamorphic source rocks. The most abundant platy clasts are varied metasedimentary rocks derived from metamorphosed Paleozoic strata, but foliated augen gneiss of Precambrian Oracle/Ruin protolith is also common. Because the metamorphism that produced the tectonite source rocks accompanied Laramide deformation, the presence of tectonite clasts in the San Manuel Formation does not bear on the time of initial unroofing of rock imprinted by mid-Tertiary mylonitic deformation within the Catalina core complex.

(3) Clasts in the plutoniclastic Kelsey Canyon facies, exposed in several drainages flanking the Galiuro Mountains between Hot Springs Canyon on the north and Kelsey Canyon on the south (Fig. 52), are dominantly lower Proterozoic granitic 
rock of the Johnny Lyon granodiorite suite, although subordinate clasts of unmetamorphosed limestone and quartzite derived from various Paleozoic formations are also ubiquitous, and minor contributions from Pinal Schist occur in some outcrops. Sediment transport to the northwest, documented by paleocurrent indicators with a NNW vector mean (Fig. 39I), suggests that the sediment provenance lay to the southeast in the Johnny Lyon Hills where a full Paleozoic section overlies Precambrian basement composed of screens of Pinal Schist intruded by large masses of Johnny Lyon Granodiorite. Clast sizes decrease on average from south to north along the outcrop belt, with massive boulder conglomerate common to the south but trough cross-bedded pebble conglomerate dominant to the north.

Along the lower course of Paige Canyon south of Cascabel, outcrops of Paige Canyon facies contain intercalated beds of Kelsey Canyon facies. Similarly, outcrops of volcaniclastic Soza Canyon facies exposed along Roble Canyon west of Cascabel contain intercalated beds of Paige Canyon facies. These stratigraphic relationships involving the three facies of the San Manuel Formation establish their approximate synchroneity. Deposition probably occurred within an integrated mid-Tertiary basin that developed along the keel of the San Pedro trough and was later disrupted by basin-range faulting.

Near the mouth of Paige Canyon, the Paige Canyon facies locally oversteps the Paige Canyon fault, which structurally bounds the principal homoclinal exposures of the unit, and rests concordantly beneath beds of the Quiburis Formation that onlap the fault block east of Paige Canyon (Fig. 52). In the same area, a low-angle normal fault that offsets the Paige Canyon facies (Lingrey, 1982) was overlapped by the Quiburis Formation. These relationships suggest that tilt-blocks growing actively during much of the interval of San Manuel sedimentation became dormant near the close of San Manuel sedimentation, and were subsequently buried beneath basin fill of the Quiburis Formation.

Quiburis Formation. Basin fill of the southern San Pedro trough was first correlated with the type Quiburis Formation near Mammoth by Agenbroad (1967). Overlying pediment and terrace gravels, separated from the Quiburis Formation by local unconformities developed during incision of basin fill, are not differentiated on Figure 52.

The depositional contact between the San Manuel and Quiburis Formations extending for $12 \mathrm{~km}$ subparallel to the Soza Ranch fault is a sharp disconformity or paraconformity (Fig. 52). Unconsolidated to poorly indurated gray beds of the gravelly Quiburis Formation rest directly on a red paleosol approximately $1 \mathrm{~m}$ thick, and two to three other paleosol horizons occur within the uppermost 10 to $12 \mathrm{~m}$ of the underlying brown Soza Canyon facies of the more firmly indurated San Manuel Formation. Given the general age relationships within the study area, this condensed section evidently represents some part of mid-Miocene time. Concordance of bedding across the contact between the San Manuel and Quiburis Formations is restricted to the central keel of the San Pedro trough. Where the Quiburis Formation onlaps the flanks of the Little Rincon and Galiuro Mountains, its contacts with the underlying Kelsey Canyon and Paige Canyon facies of the San Manuel Formation are angular unconformities (Fig. 52).

\section{Cienega Gap area}

Despite consistent dips $\left(25\right.$ to $45^{\circ}$ ) to the east and northeast, exposures of the Pantano Formation in Cienega Gap (Fig. 34) are laced internally by multiple normal faults of variable dip that moved in uncertain sequence and repeat parts of the Pantano section in complex patterns (Drewes, 1977; Balcer, 1984). The structural complexity of Pantano outcrops may reflect widespread overprinting of early-formed detachment features by later structures active during secondary breakaway within the detachment system. South of Pantano Wash, tilted partial sections of Pantano Formation (Fig. 55) rest unconformably on pre-Tertiary rocks of multiple tilt-blocks within the upper plate of the Catalina detachment system. North of Pantano Wash, the Pantano Formation is in direct contact with mylonitic gneiss of the Catalina core complex along segments of the Catalina detachment fault. Near Rincon Valley, southwest of the Rincon Mountains, local klippen of Pantano Formation lie discordantly above pre-Tertiary cover rocks along subsidiary strands of the detachment system. An intercalated lava flow of latest Oligocene age ( $25 \mathrm{Ma})$ indicates that Pantano sedimentation spanned the Oligocene-Miocene time boundary and was coeval with displacements along the Catalina detachment system.

The basal conglomerate and sandstone member of the Pantano Formation is composed dominantly of normally graded beds of sandy conglomerate and pebbly sandstone, interpreted as a braidplain facies, in which gravel clasts are dominantly sandstone derived from the Bisbee Group. The overlying limestone and sandstone member is dominantly similar pebbly sandstone, interpreted as a fan delta facies, but also contains intercalated laminated sandstone of marginal sandflat facies and oncolitic limestone of marginal lacustrine facies. The middle conglomerate member, interpreted as an alluvial fan facies, contains multiple coarsening-upward cycles, each 10 to $25 \mathrm{~m}$ thick, in which the most abundant clasts are felsic Laramide volcanic rocks and sandstones from the Bisbee Group. Paleocurrent indicators define overall westward paleoflow (Fig. 39N) during fan progradation, but local fans were built into the Cienega Gap area from the north and the south as well as from the east (Balcer, 1984). The andesitic to latitic lava (Table 7) intercalated within the Pantano Formation was erupted onto the compound surface of coalescing alluvial fans constructed by deposition of the middle conglomerate member.

Eruption of the lava was apparently associated with a reversal of paleodrainage, for paleocurrent indicators in the alluvial fan and braidplain facies at the base of the upper mudstone member reflect paleoflow back to the northeast (Balcer, 1984). The lacustrine mudstone that forms the bulk of this member was probably 


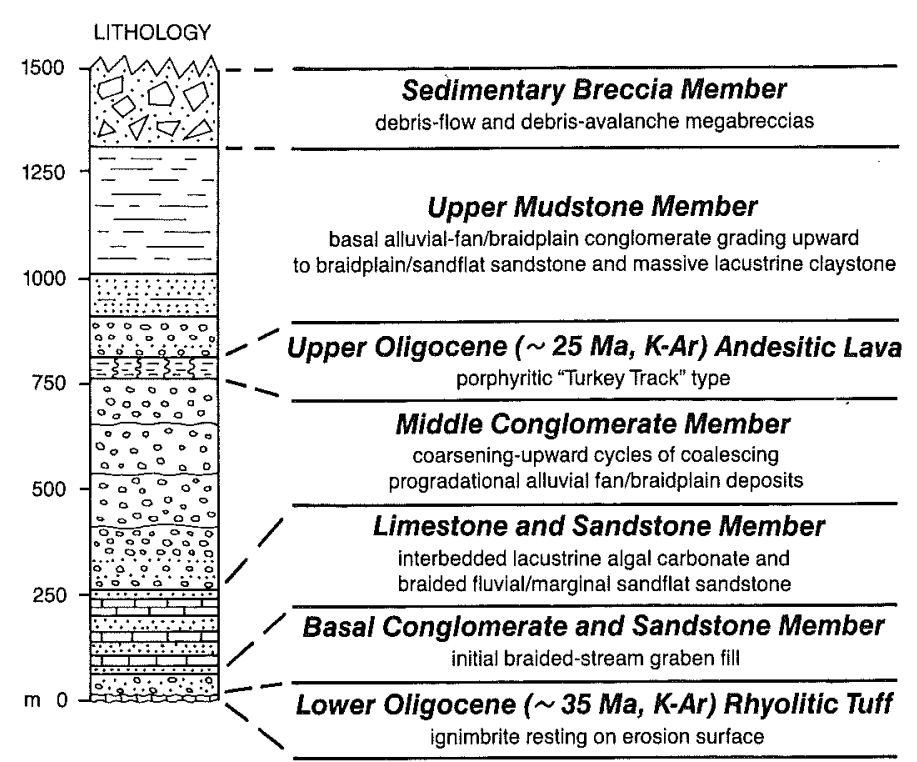

Figure 55. Columnar section of Pantano Formation in Cienega Gap area (after Balcer, 1984). See Figure 34 for location.

ponded within a half-graben basin, bounded by a fault scarp on the northeast, into which fluvial systems drained from the backslope of a tilt-block lying to the southwest. The uppermost sedimentary breccia member, composed of thick debris-avalanche deposits that buried parts of the lake floor, was derived from sources to the north or northeast (Yarnold and Lombard, 1989). It contains debris derived mainly from "Rincon Valley Granodiorite" of the Precambrian Johnny Lyon granodiorite suite but in part from Cambrian sedimentary units as well. Its emplacement may reflect the appearance of a nearby fault scarp associated with initiation of a secondary breakaway system along the Rincon Mountains front of the Catalina core complex.

The provenance of the Pantano Formation was made up entirely of rock units that occur now only in the upper plate of the Catalina detachment system, either within Cienega Gap itself or as part of the Empire Mountains to the south. Gravel clast counts indicate the following overall contents of debris from different source rocks (Balcer, 1984): quartzofeldspathic sandstone of the Bisbee Group ( 60 percent), felsic tuff and porphyry of Laramide age (15 percent), gray laminated limestone of the Bisbee Group (10 percent), quartzite and other Precambrian or Paleozoic strata (10 percent), and porphyritic mid-Tertiary andesite or latite lithologically similar to intercalated Pantano volcanic rocks (5 percent).

Overlying Neogene deposits partly equivalent in age to the Quiburis Formation of the San Pedro trough, and partly representative of younger terrace systems incised into a series of paleolandscapes, rest unconformably upon the Pantano Formation and mask many of its exposures except in fresh stream and road cuts. Further study is needed to differentiate these younger stratigraphic units in Cienega Gap, and to establish their relationships to local geomorphic features. Strata intermediate in age between
Pantano and Quiburis depositional events may be present. In the subsurface of the nearby Tucson Basin, erosional remnants of Pantano Formation are preserved only within buried grabens. Neogene basin fill is draped across the flanks of the subsurface grabens without significant offset by graben-bounding faults (Eberly and Stanley, 1978, Fig. 11).

\section{DISCUSSION AND CONCLUSIONS}

Tertiary sedimentation in southern Arizona included: (1) diachronous mid-Tertiary phases that preceded, accompanied, and followed a migratory regional pulse of magmatism including ignimbrite eruptions; and (2) a Neogene phase of basin filling associated with basin-range faulting (Scarborough, 1979, 1989; Scarborough and Wilt, 1979; Wilt and Scarborough, 1981). Detachment faulting that denuded the Catalina core complex was underway during mid-Tertiary phases of sedimentation in the San Pedro trough and nearby depocenters, but deposition of Neogene basin fill postdated displacements along the detachment system.

\section{General and regional relations}

The site of the Catalina core complex is part of a once-stable continental block formed by Proterozoic crustal genesis that culminated with intrusion of voluminous granitic plutons. Overlying Precambrian and Paleozoic platform cover, with a total stratigraphic thickness of only $\sim 2,500 \mathrm{~m}$, was augmented by $\sim 1,000$ $\mathrm{m}$ of pre-Laramide Mesozoic strata. Laramide orogenesis during latest Cretaceous and early Tertiary time substantially modified the local crustal profile by thrusting, emplacement of granitic plutons, and eruption of widespread volcanic fields. Laramide thrusts involved basement rocks but also telescoped their stratigraphic cover. Some mylonitic rocks within the Catalina core complex are Laramide tectonites. The youngest Laramide rock assemblage is peraluminous two-mica granite, which occupies nearly half the exposed interior of the Catalina core complex. Laramide deformation was succeeded by an early Tertiary interval of comparative tectonic quiescence during which deep erosion exposed Precambrian basement and deformed younger rocks over wide areas.

Mylonitic deformation and related detachment faulting along the flank of the Catalina core complex accompanied a mid-Tertiary phase of taphrogeny. Throughout the intermountain region, extensional deformation was marked by listric or rotational normal faulting associated with polymodal arc magmatism. Exposed mylonitic gneisses of the Catalina core complex formed in the midcrust at an estimated mean depth of 10 to $12 \mathrm{~km}$, and were brought near the surface by translation along a brittleductile shear zone. The resulting detachment fault was arched over the Catalina core complex by isostatic uplift in response to tectonic denudation. Detachment structures were overprinted by Neogene block faulting during the post-mid-Miocene basin-range phase of intermountain taphrogeny. The steepest escarpments 
bounding the Santa Catalina and Rincon Mountains lie along the upthrown sides of steep normal faults, which offset more gently dipping fault strands of the detachment system that delineates the Catalina core complex.

\section{Syntectonic mid-Tertiary strata}

The Galiuro Volcanics, the volcanic lower member of the Cloudburst Formation, and correlative volcanic rocks of the Tucson Mountains were erupted during a late Oligocene pulse of polymodal arc magmatism that heralded the onset of denudational mid-Tertiary detachment faulting. Volcanism was accompanied locally by coarse clastic and minor lacustrine sedimentation within incipient extensional basins in which the Mineta Formation, the lower Pantano Formation, and portions of the Hackberry Wash facies of the Cloudburst Formation were deposited. In much of the study area, laterally extensive upper Oligocene volcanic fields contain only minor intercalated nonvolcanic strata, and prevolcanic or synvolcanic sedimentary sequences are not widespread.

Shortly after eruption, the mid-Tertiary volcanic blanket was intricately disrupted by extensional faulting throughout the area surrounding the Catalina core complex. Substantial fault offsets allowed downdropped volcanic sequences and eroded older bedrock to be covered by thick successions of uppermost Oligocene to lower Miocene conglomeratic and associated lacutrine facies in the Pantano, Cloudburst, and San Manuel Formations. The sedimentary sequences are exposed now as tilted homoclinal successions that rest depositionally on up-ended tilt-blocks composed of older rocks, but are truncated downdip by normal faults of variable dip.

The syntectonic upper Oligocene and lower Miocene strata were deposited mainly as alluvial fans and braidplains, together with associated finer-grained floodplain and lacustrine facies, within multiple and compound half-grabens. These extensional basins developed throughout most of the study area west of the range front of the Galiuro Mountains, which marked the initial breakaway zone for the detachment system bounding the Catalina core complex. Aggradation of upper Oligocene and lower Miocene nonmarine strata, derived from sources in adjacent or nearby tilt-blocks, filled half-graben basins in diachronous patterns that involved: (1) conformable succession in basin keels, (2) progressive onlap of basin flanks along buttress unconformities, (3) overlap of incrementally deformed and eroded older horizons of syntectonic strata, and (4) local overstep of the eroded crests of bedrock tilt-blocks.

\section{Detachment timing and displacement}

Uppermost Oligocene and lowermost Miocene sedimentation was coeval with retrograde mylonitic deformation and superposed detachment faulting along the brittle-ductile shear zone bounding the Catalina core complex. Closing phases of midTertiary sedimentation within and adjacent to the Tucson Basin were associated with the development of a secondary breakaway zone above the present structural front of the Catalina core complex. Along the San Pedro trough, older horizons of the syntectonic facies assemblage abut downdip against subhorizontal strands of the detachment system, but younger Miocene horizons abut downdip against normal faults of moderate dip that offset detachment structures.

The structural history of individual, gently dipping, and even backtilted normal faults exposed along the San Pedro trough is problematical. Some are probably deformed updip segments of the main detachment fault. Others may be subsidiary fault strands that played an integral role in the detachment system as splay faults branching upward from an underlying detachment surface. Still others clearly cut beneath the Catalina core complex. Whether listric or planar, many were possibly initiated as comparatively steep faults within the migratory breakaway zone, and rotated to their present attitudes as crustal extension continued after the headwall rupture for the detachment system had migrated westward.

Net displacement across the Catalina detachment system is estimated as 20 to $30 \mathrm{~km}$ based on approximate offsets of contacts between rock masses within Precambrian basement and on the distributions of key Phanerozoic units. Probable northward decrease in displacement was possibly balanced by northward increase in cumulative displacement across the multiple normal faults of the San Pedro trough. As displacements along splays of the detachment system were additive downdip, the tectonic transport of allochthons stranded above the antiformal uplift of the Catalina core complex was typically only 10 to $12 \mathrm{~km}$.

\section{Post-detachment Neogene history}

Half-graben basins associated with early Miocene extensional deformation along the San Pedro trough continued to evolve after displacements along much of the Catalina detachment system had ceased. Consequently, faults bounding younger half-graben basins offset older fault strands active earlier in the structural history of composite basins. By mid-Miocene time, reduction in the rate of extensional deformation promoted widespread aggradation. Sedimentation ultimately buried a rugged mid-Tertiary paleotopography of corrugated tilt-blocks beneath essentially undeformed Neogene basin fill of the San Pedro trough and the Tucson Basin. Facies patterns in basin fill are congruent with modern topography, and reflect construction of alluvial fans built from sources in flanking ranges toward lacustrine and floodplain environments on basin floors.

Basin-range block faulting that accompanied deposition of post-mid-Miocene basin fill gave rise locally to prominent escarpments and steep basin margins, but gross morphologic features of the study area are largely remnants of a mid-Miocene paleolandscape. Integration of the Gila River drainage system into the evolving Gulf of California during Pliocene time led to erosional dissection of basin fill along the San Pedro trough, and of correlative sediment cover that had accumulated across topographically subdued portions of the surrounding uplands. 


\section{Kinematic and geometric uncertainties}

Defining in detail the kinematic evolution of the Catalina detachment system remains a challenge. Its overall configuration is known well enough to define the outline of the Catalina core complex, but data are lacking to establish accurately the diachroneity of displacements along different segments of the bounding detachment fault. Critical information bearing on this point lies buried in the subsurface of the Tucson Basin.

Observed dihedral angles between tilted bedding in homoclines of syntectonic strata and low-angle mid-Tertiary normal faults, into which the beds abut downdip, imply that the faults were steeply dipping near the surface where the strata were subhorizontal prior to offset. The faults can be interpreted either as listric structures, perhaps splays curving upward from a master detachment surface at depth, or as rotational planar faults. The former interpretation is compatible with the standard geometric model for gently dipping detachment systems to control tectonic denudation of Cordilleran metamorphic core complexes.

The latter interpretation challenges the prevailing model because fault strands commonly interpreted as updip extensions of a master detachment surface might instead be separate rotational planar faults. If flat faults that now underlie extensional allochthons were once steep faults that rotated in place, presumed interconnections between different allochthons would be invalid. The current interpretation of Catalina detachment structures as a coherent system of linked fault segments seemingly refutes the idea that the detachment system could be a composite of such disconnected rotational segments. Future work should be designed, nevertheless, to test this unlikely possibility because it is the most dramatic way in which current notions of local structural style could be in error. Reaching a conclusive decision on this point is inherently difficult, because rotational faults that do exist might have been active only at shallow crustal levels within the upper distended plate of the detachment system.

\section{REFERENCES CITED}

Agenbroad, L. D., 1967, Cenozoic stratigraphy and paleohyrology of the Redington-San Manual area, San Pedro valley, Arizona [Ph.D. thesis]: Tucson, University of Arizona, $119 \mathrm{p}$.

Aldrich, M. J., Jr., 1986, Tectonics of the Jemez lineament in the Jemez Mountains and Rio Grande Rift: Journal of Geophysical Research, v. 91, p. $1753-1762$.

Allmendinger, R. W., and 7 others, 1983, Cenozoic and Mesozoic structure of the eastern Basin and Range province, Utah, from COCORP seismic-reflection data: Geology, v. 11, p. 532-536.

Anderson, J. L., 1983, Proterozoic anorogenic granite plutonism of North America, in Medaris, L. D., Jr., Byers, C. W., Mickelson, D. M., and Shanks, W. C., eds., Proterozoic geology: Geological Society of America Memoir 161, p. 133-154.

— , 1988, Core complexes of the Mojave-Sonoran desert; Conditions of plutonism, mylonitization, and decompression, in Ernst, W. G., ed., Metamorphism and crustal evolution of the western United States: Englewood Cliffs, New Jersey, Prentice-Hall, p. 502-525.

Anderson, J. L., and Rowley, M. C., 1981, Synkinematic intrusion of peraluminous and associated metaluminous granitic magmas, Whipple Mountains,
California: Canadian Mineralogist, v. 19, p. 83-101.

Anderson, J. L., Barth, A. P., and Young, E. D., 1988, Mid-crustal Cretaceous roots of Cordilleran metamorphic core complexes: Geology, v. 16, p. 366-369.

Anderson, R. E., 1971, Thin skin extension in Tertiary rocks of southeastern Nevada: Geological Society of America Bulletin, v. 82, p. 43-58.

Anderson, R. E., Longwell, C. R., Armstrong, R. L., and Marvin, R. F., 1972, Significance of $\mathrm{K}-\mathrm{Ar}$ ages of Tertiary rocks from the Lake Mead region, Nevada-Arizona: Geological Society of America Bulletin, v. 83, p. 273-288.

Anderson, S. R., 1987, Cenozoic stratigraphy and geologic history of the Tucson Basin, Pima County, Arizona: U.S. Geological Survey Water Resources Investigations Report 87-4190, $20 \mathrm{p}$.

Annis, D. R., and Keith, S. B., 1986, Petrochemical variation in post-Laramide igneous rocks in Arizona and adjacent regions; Geotectonic and metallogenic implications, in Beatty, B., and Wilkinson, P.A.K., eds., Frontiers in geology and ore deposits of Arizona and the Southwest: Arizona Geological Society Digest, v. 16, p. 488-456.

Arguden, A. T., and Rodolfo, K. S., 1986, Sedimentary facies and tectonic implications of lower Mesozoic alluvial-fan conglomerates of the Newark Basin, northeastern United States: Sedimentary Geology, v. 51, p. 97-118.

Armin, R. A., 1987, Sedimentology and tectonic significance of Wolfcampian (Lower Permian) conglomerates in the Pedregosa basin; Southeastern Arizona, southwestern New Mexico, and northern Mexico: Geological Society of America Bulletin, v. 99, p. 42-65.

Armstrong, R. L., 1972, Low-angle (denudation) faults, hinterland of the Sevier orogenic belt, eastern Nevada and western Utah: Geological Society of America Bulletin, v. 83, p. 1729-1754.

- 1974 , Geochronology of the Eocene volcanic and plutonic episode in Idaho: Northwest Geology, v. 3, p. 1-15.

— , 1982, Cordilleran metamorphic core complexes from Arizona to southern Canada: Annual Reviews of Earth and Planetary Sciences, v. 10, p. 129-154.

— , 1988, Mesozoic and early Cenozoic magmatic evolution of the Canadian Cordillera, in Clark, S. P., Jr., Burchfiel, B. C., and Suppe, J., eds., Processes in continental lithospheric deformation: Geological Society of America Special Paper 218, p. 55-91.

_- , 1990, Cenozoic magmatism in the North American Cordillera and the origin of metamorphic core complexes: Geological Society of America Abstracts with Programs, v. 22, p. 4.

Armstrong, R. L., Leeman, W. P., and Malde, H. E., 1975, K-Ar dating, Quaternary and Neogene volcanic rocks of the Snake River Plain, Idaho: American Journal of Science, v. 275, p. 225-251.

Atwater, T., 1970, Implications of plate tectonics for the Cenozoic tectonic evolution of western North America: Geological Society of America Bulletin, v. 81, p. 3513-3536.

Balcer, R. A., 1984, Stratigraphy and depositional history of the Pantano Formation (Oligocene-early Miocene), Pima County, Arizona [M.S. thesis]: Tucson, University of Arizona, $107 \mathrm{p}$.

Baldridge, W. S., Damon, P. E., Shafiqullah, M., and Bridwell, R. J., 1980, Evolution of the central Rio Grande rift, New Mexico; New potassiumargon dates: Earth and Planetary Science Letters, v. 51, p. 309-321.

Baldridge, W. S., and 9 others, 1989, Magmatism associated with lithospheric extension; Middle to late Cenozoic magmatism of the southeastern Colorado Plateau and central Rio Grande rift, New Mexico and Arizona, in Chapin, C. E., and Zidek, J., Field excursions to volcanic terranes in the western United States; Vol. I, Southern Rocky Mountain region: New Mexico Bureau of Mines and Mineral Resources Memoir 46, p. 187-202.

Ballance, P. F., 1984, Sheet-flow-dominated gravel fans of the non-marine middle Cenozoic Simmler Formation, central California: Sedimentary Geology, v. 38, p. $337-359$.

Banks, N. G., 1976, Reconnaissance geologic map of the Mount Lemmon Quadrangle, Arizona: U.S. Geological Survey Miscellaneous Field Studies Map MF-747, scale 1:62,500.

— 1980, Geology of a zone of metamorphic core complexes in southeastern Arizona, in Crittenden, M. D., Jr., Coney, P. J., and Davis, G. H., eds., 
Cordilleran metamorphic core complexes: Geological Society of America Memoir 153, p. 177-215.

Banks, N. G., and Krieger, M. H., 1977, Geologic map of the Hayden Quadrangle, Pinal and Gila Counties, Arizona: U.S. Geological Survey Geologic Quadrangle Map GQ-1391, scale 1:24,000 with 15 p. text.

Banks, N. G., and 7 others, 1977, Reconnaissance geologic map of the Tortolita Mountains Quadrangle, Arizona: U.S. Geological Survey Miscellaneous Field Studies Map MF-864, scale 1:62,500.

Banks, N. G., McKee, E. H., Keith, S. B., Shafiqullah, M., and Damon, P. E., 1978, Radiometric and chemical data for rocks of the Tortolita Mountains 15' Quadrangle, Pinal County, Arizona: Isochron/West no. 22, p. 17-22.

Barker, D. S., 1979, Cenozoic magmatism in the Trans-Pecos province; Relation to the Rio Grande Rift, in Riecker, R. E., ed., Rio Grande Rift; Tectonics and magmatism: Washington, D.C., American Geophysical Union, p. 382-392.

Barr, D., 1987, Structural/stratigraphic models for extensional basins of halfgraben type: Journal of Structural Geology, v. 9, p. 491-500.

Barter, C. F., 1962, Geology of the Owl Head Mining District, Pinal County, Arizona [M.S. thesis]: Tucson, University of Arizona, 73 p.

Barter, C. F., and Kelly, J. L., 1982, Geology of the Twin Buttes mineral deposit, Pima Mining District, Pima County, Arizona, in Titley, S. R., ed., Advances in geology of the porphyry copper deposits, southwestern North America: Tucson, University of Arizona Press, p. 407-432.

Bartley, J. M., and Wernicke, B. P., 1984, The Snake Range decollement interpreted as a major extensional shear zone: Tectonics, v. 3, p. 647-657.

Bartley, J. M., Axen, G. J., Taylor, W. J., and Fryxell, J. E., 1988, Cenozoic tectonics of a transect through eastern Nevada near $38^{\circ} \mathrm{N}$. latitude, in Weide, D. L., and Faber, M. L., eds., This extended land; Geological journeys in the southern Basin and Range: Las Vegas, University of Nevada, Department of Geoscience Special Publication 2, p. 1-20.

Bartley, J. M., Fletcher, J. M., and Glazner, A. F., 1990, Tertiary extension and contraction in the central Mojave metamorphic core complex, southern California: Tectonics, v. 9, p. 521-534.

Beatty, B., 1987, Correlation of some mid-Mesozoic redbeds in the Santa Rita Mountains, Mustang Mountains, and Canelo Hills, southeastern Arizona [M.S. thesis]: Tucson, University of Arizona, $30 \mathrm{p}$.

Benson, G. S., 1981, Structural investigations of the Italian Trap allochthon, Redington Pass, Pima County, Arizona [M.S. thesis]: Tucson, University of Arizona, $85 \mathrm{p}$.

Best, M. G., 1986, Tertiary geology of the area between Milford, Utah, and Pioche, Nevada, in Griffen, D. T., and Phillips, W. R., eds., Thrusting and extensional structures and mineralization in the Beaver Dam Mountains, southwestern Utah: Utah Geological Association Publication 15, p. 77-86.

Best, M. G., McKee, E. H., and Damon, P. E., 1980, Space-time composition patterns of late Cenozoic mafic volcanism, southwestern Utah and adjoining areas: American Journal of Science, v. 280, p. 1035-1050.

Best, M. G., and 5 others, 1989, Eocene through Miocene volcanism in the Great Basin of the western United States, in Chapin, C. E., and Zidek, J., eds., Field excursions to volcanic terranes in the western United States: Vol. 2, Cascades and intermountain west: New Mexico Bureau of Mines and Mineral Resources Memoir 47, p. 91-133.

Bikerman, M., and Damon, P. E., 1966, K/Ar chronology of the Tucson Mountains, Pima County, Arizona: Geological Society of America Bulletin, v. 77, p. $1225-1234$.

Bilodeau, W. L., and Lindberg, F. A., 1983, Early Cretaceous tectonics and sedimentation in southern Arizona, southwestern New Mexico, and northern Sonora, Mexico, in Reynolds, M. W., and Dolly, E. D., eds., Mesozoic paleogeography of the west-central United States: Rocky Mountain Section, Society of Economic Paleontologists and Mineralogists Rocky Mountain Paleogeography Symposium 2, p. 173-188.

Bird, P., 1984, Laramide crustal thickening event in the Rocky Mountain foreland and Great Plains: Tectonics, v. 3, p. 741-758.

— , 1988, Formation of the Rocky Mountains, western United States; A continuum computer model: Science, v. 239, p. 1501-1507.
Blacet, P. M., and Miller, S. T., 1978, Reconnaissance geologic map of the Jackson Mountain Quadrangle, Graham County, Arizona: U.S. Geological Survey Miscellaneous Field Studies Map MF-939, scale 1:62,500.

Blair, T. C., and Bilodeau, W. L., 1988, Development of tectonic cyclothems in rift, pull-apart, and foreland basins; Sedimentary response to episodic tectonism: Geology, v. 16, p. 517-520.

Bogen, N. L., and Schweickert, R. A., 1985, Magnitude of extension across the northern Basin and Range province; Constraints from paleomagnetism: Earth and Planetary Science Letters, v. 75, p. 93-100.

Bohannon, R. G., 1984, Nonmarine sedimentary rocks of Tertiary age in the Lake Mead region, southeastern Nevada and northwestern Arizona: U.S. Geological Survey Professional Paper 1259, 72 p.

Bosworth, W., 1985, Geometry of propagating continental rifts: Nature, v. 316, p. 625-627.

Brennan, D. J., 1957, Geological reconnaissance of Cienega Gap, Pima County, Arizona [M.S. thesis]: Tucson, University of Arizona, $53 \mathrm{p}$.

_ , 1962, Tertiary sedimentary rocks and structures of the Cienega Gap area, Pima County, Arizona: Arizona Geological Society Digest, v. 5, p. 45-57.

Brooks, W. E., 1986, Distribution of anomalously high $\mathrm{K}_{2} \mathrm{O}$ volcanic rocks in Arizona; Metasomatism at the Picacho Peak detachment fault: Geology, v. 14, p. $339-342$.

Brown, R. L., and Journeay, J. M., 1987, Tectonic denudation of the Shuswap metamorphic terrane of southeastern British Columbia: Geology, v. 15, p. $142-146$.

Bryan, K., 1926, San Pedro valley, Arizona, and the geographical cycle [abs.]: Geological Society of America Bulletin, v. 37, p. 169-170.

Bryant, B., Naeser, C. W., Marvin, R. F., and Mehnert, H. H., 1989, Ages of late Paleogene tuffs and the beginnings of rapid regional extension, eastern boundary of the Basin and Range province near Salt Lake City, Utah: U.S. Geological Survey Bulletin 1787-K, p. K1-K11.

Bryant, D. L., 1968, Diagnostic characteristics of the Paleozoic formations of southeastern Arizona, in Titley, S. R., ed., Southern Arizona Guidebook 3: Tucson, Arizona Geological Society, p. 33-47.

Buck, W. R., 1988, Flexural rotation of normal faults: Tectonics, v. 7, p. 959-973.

Budden, R. T., 1975, The Tortolita-Santa Catalina Mountain complex [M.S. thesis]: Tucson, University of Arizona, $133 \mathrm{p}$.

Burchfiel, B. C., 1966, Tin Mountain landslide, southeastern California, and the origin of megabreccia: Geological Society of America Bulletin, v. 77, p. $95-100$.

Burchfiel, B. C., and Stewart, J. H., 1966, "Pull-apart" origin of the central segment of the Death Valley, California: Geological Society of America Bulletin, v. 77, p. 439-442.

Burke, D. B., Hillhouse, J. W., McKee, E. H., Miller, S. T., and Morton, J. L., 1982, Cenozoic rocks in the Barstow Basin area of southern California; Stratigraphic relations, radiometric ages, and paleomagnetism: U.S. Geological Survey Bulletin 1529-E, p. E1-E16.

Byers, F, M., Jr., Carr, W. J., and Orkild, P. P., 1989, Volcanic centers of southwestern Nevada; Evolution of understanding 1960-1988: Journal of Geophysical Research, v. 94, p. 5908-5924.

Bykerk-Kauffman, A., 1983, Kinematic analysis of deformation at the margin of a regional shear zone, Buehman Canyon area, Santa Catalina Mountains, Arizona [M.S. thesis]: Tucson, University of Arizona, 79 p.

_, 1986 , Multiple episodes of ductile deformation within the lower plate of the Santa Catalina metamorphic core complex, southeastern Arizona, in Beatty, B., and Wilkinson, P.A.K., eds., Frontiers in geology and ore deposits of Arizona and the Southwest: Arizona Geological Society Digest, v. 16, p. $460-464$.

_ 1990, Structural evolution of the northeastern Santa Catalina Mountains, Arizona; A glimpse of the pre-extension history of the Catalina complex [Ph.D. thesis]: Tucson, University of Arizona, 195 p.

Bykerk-Kauffman, A., and Janecke, S. U., 1987, Late Cretaceous to early Tertiary ductile deformation; Santa Catalina-Rincon metamorphic core complex, southeastern Arizona: Geology, v. 15, p. 462-465.

Cameron, K. L., Nimz, G. J., Kuentz, D., Niemeyer, S., and Gunn, S., 1989, 
Southern Cordilleran basaltic andesitic suite, southern Chihuahua, Mexico; A link between Tertiary continental arc and flood basalt magmatism in North America: Journal of Geophysical Research, v. 94, p. 7817-7840.

Cameron, M., Bagby, W. C., and Cameron, K. L., 1980, Petrogenesis of voluminous mid-Tertiary ignimbrites of the Sierra Madre Occidental, Chihuahua, Mexico: Contributions to Mineralogy and Petrology, v. 74, p. 271-284.

Cameron, M., Cameron, K. L., Sawlan, M., and Gunderson, R., 1983, Calcalkalic volcanism in Chihuahua, Mexico; Its regional geochemical context, in Clark, K. F., and Goodell, P. C., eds., Geology and mineral resources of north-central Chihuahua: El Paso Geological Society Publication 15, p. 94-107.

Cape, C. D., McGeary, S., and Thompson, G. A., 1983, Cenozoic normal faulting and the shallow structure of the Rio Grande rift near Socorro, New Mexico: Geological Society of America Bulletin, v. 94, p. 3-14.

Carr, S. D., Parrish, R. R., and Brown, R. L., 1987, Eocene structural development of the Valhalla Complex, southeastern British Columbia: Tectonics, v. 6, p. 175-196.

Cather, S. M., 1989, Post-Laramide tectonic and volcanic transition in west-central New Mexico, in Anderson, O. J., Lucas., S. G., Love, D. W., and Cather, S. M., eds., Southeastern Colorado Plateau: New Mexico Geological Society 40th Annual Field Conference Guidebook, p. 91-97.

— , 1990, Stress and volcanism in the northern Mogollon-Datil volcanic field, New Mexico; Effects of the post-Larmide tectonic transition: Geological Society of America Bulletin, v. 102, p. 1447-1458.

Cather, S. M., and Chapin, C. E., 1989, Field guide to upper Eocene and lower Oligocene volcaniclastic rocks of the northern Mogollon-Datil volcanic field, in Chapin, C. E., and Zidek, J., eds., Field excursions to volcanic terranes in the western United States; Vol. 1, Southern Rocky Mountain region: New Mexico Bureau of Mines and Mineral Resources Memoir 46, p. 60-68.

Cather, S. M., McIntosh, W. C., and Chapin, C. E., 1987, Stratigraphy, age, and rates of deposition of the Datil Group (Upper Eocene-Lower Oligocene), west-central New Mexico: New Mexico Geology, v. 9, p. 50-54.

Cemen, I., Wright, L. A., Drake, R. E., and Johnson, F. C., 1985, Cenozoic sedimentation and sequence of deformational events at the southeastern end of the Furnace Creek strike-slip fault zone, Death Valley region, California, in Biddle, K. T., and Christie-Blick, N., eds., Strike-slip deformation, basin formation, and sedimentation: Society of Economic Paleontologists and Mineralogists Special Publication 37, p. 127-141.

Chadwick, R. A., 1985, Overview of Cenozoic volcanism in the west-central United States, in Flores, R. M., and Kaplan, S. S., eds., Cenozoic paleogeography of the west-central United States: Rocky Mountain Section, Society of Economic Paleontologists and Mineralogists Rocky Mountain Paleogeography Symposium 3, p. 359-382.

Chamberlin, R. M., 1983, Cenozoic domino-style crustal extension in the Lemitar Mountains, New Mexico; A summary, in Chapin, C. E., ed., Socorro region II: New Mexico Geological Society 34th Annual Field Conference Guidebook, p. 111-118.

Chapin, C. E., 1988, Axial basins of the northern and central Rio Grande rift, in Sloss, L. L., ed., Sedimentary cover; North American craton; U.S.: Boulder, Colorado, Geological Society of America, The Geology of North America, v. D-2, p. $165-170$.

- 1989, Volcanism along the Socorro accommodation zone, Rio Grande rift, New Mexico, in Chapin, C. E., and Zidek, J., eds., Field excursions to volcanic terranes in the western United States; Vol. 1, Southern Rocky Mountain region: New Mexico Bureau of Mines and Mineral Resources Memoir 46, p. 46-57.

Chapin, C. E., and Lindley, J. I., 1986, Potassium metasomatism of igneous and sedimentary rocks in detachment terranes and other sedimentary basins, in Beatty, B., and Wilkinson, P.A.K., eds., Frontiers in geology and ore deposits of Arizona and the Southwest: Arizona Geological Society Digest, v. 16, p. $118-126$.

Chapin, C. E., and Seager, W. R., 1975, Evolution of the Rio Grande rift in the Socorro and Las Cruces areas, in Seager, W. R., Clemons, R. E., and Callender, J. F., eds., Guidebook of the Las Cruces country: New Mexico
Geological Society 26th Annual Field Conference Guidebook, p. 297-321.

Chen, W. P., and Molnar, P., 1983, Focal depths of intracontinental and intraplate earthquakes and their implications for the thermal and mechanical properties of the lithosphere: Journal of Geophysical Research, v. 88, p. 4183-4214.

Chew, R. T., III, 1952, Geology of the Mineta Ridge area, Pima and Cochise Counties, Arizona [M.S. thesis]: Tucson, University of Arizona, 53 p.

, 1962, The Mineta Formation, a middle Tertiary unit in southeastern Arizona: Arizona Geological Society Digest, v. 5, p. 35-43.

Christiansen, R. L., and Lipman, P. W., 1972, Cenozoic volcanism and platetectonic evolution of the western United States; 2, Late Cenozoic: Philosophical Transactions of the Royal Society of London, v. A271, p. 249-284.

Christiansen, R. L., and McKee, E. H., 1978, Late Cenozoic volcanic and tectonic evoluton of the Great Basin and Columbia intermontane regions, in Smith, R. B., and Eaton, G. P., eds., Cenozoic tectonics and regional geophysics of the western Cordillera: Geological Society of America Memoir 152, p. 283-311.

Christiansen, R. L., and Yeats, R. S., 1991, Post-Laramide geology of the Cordilleran region, in Burchfiel, B. C., Lipman, P. W., and Zoback, M. L., eds., The Cordilleran orogen; Conterminous United States: Boulder, Colorado, Geological Society of America, The Geology of North America, v. G-3, in press.

Clark, K. F., Foster, C. T., and Damon, P. E., 1982, Cenozoic mineral deposits and subduction-related magmatic arcs in Mexico: Geological Society of America Bulletin, v. 93, p. 533-544.

Clay, D. W., 1970, Stratigraphy and petrology of the Mineta Formation in Pima and eastern Cochise Counties, Arizona [Ph.D. thesis]: Tucson, University of Arizona, $187 \mathrm{p}$.

Condie, K. C., and DeMalas, J. P., 1985, The Pinal Schist; An Early Proterozoic quartz wacke association in southeastern Arizona: Precambrian Research, v. 27, p. $337-356$.

Coney, P. J., 1971, Cordilleran tectonic transitions and motion of the North American plate: Nature, v. 233, p. 462-465.

_ 1976, Plate tectonics and the Laramide orogeny, in Woodward, L. A., and Northrop, S. A., eds., Tectonics and mineral resources of southwestern North America: New Mexico Geological Society Special Publication 6, p. 5-9.

_ 1978, The plate tectonic setting of southeastern Arizona, in Callender, J. F., Wilt, J. C., and Clemons, R. E., eds., Land of Cochise, southeastern Arizona: New Mexico Geological Society 29th Field Conference Guidebook, p. 285-290,

, 1979, Tertiary evolution of Cordilleran metamorphic core complexes, in Armentrout, J. M., Cole, M. R., and TerBest, H., Jr., eds., Cenozoic paleogeography of the western United States: Pacific Section, Society of Economic Paleontologists and Mineralogists Pacific Coast Paleogeography Symposium 3, p. 15-28.

— , 1980a, Introduction, in Crittenden, M. D., Jr., Coney, P. J., and Davis, G. H., eds., Cordilleran metamorphic core complexes: Geological Society of America Memoir 153, p. 3-6.

_ , 1980b, Cordilleran metamorphic core complexes; An overview, in Crittenden, M. D., Jr., Coney, P. J., and Davis, G. H., eds., Cordilleran metamorphic core complexes: Geological Society of America Memoir 153, p. $7-31$.

, 1987, The regional tectonic setting and possible causes of Cenozoic extension in the North American Cordilleran, in Coward, M. P., Dewey, J. F., and Hancock, P. L., eds., Continental extensional tectonics: Geological Society of London Special Publication 28, p. 177-186.

Coney, P. J., and Harms, T. A., 1984, Cordilleran metamorphic core complexes; Cenozoic extensional relics of Mesozoic compresson: Geology, v. 12, p. 550-554.

Coney, P. J., and Reynolds, S. J., 1977, Cordilleran Benioff zones: Nature, v. 270, p. 403-406.

Cooley, M. E., 1968, Some notes on the late Cenozoic drainage patterns in southeastern Arizona and southwestern New Mexico, in Titley, S. R., ed., Southern Arizona Guidebook 3: Tucson, Arizona Geological Society, p. 75-78. 
Cooper, J. R., 1960, Some geologic features of the Pima Mining District, Pima County, Arizona: U.S. Geological Survey Bulletin 1112-C, p. C1-C103.

,1973, Geologic map of the Twin Buttes Quadrangle, southwest of Tucson, Pima County, Arizona: U.S. Geological Survey Miscellaneous Geologic Investigations Map I-745, scale 1:48,000.

Cooper, J. R., and Silver, L. T., 1964, Geology and ore deposits of the Dragoon Quadrangle, Cochise County, Arizona: U.S. Geological Survey Professional Paper 416, $196 \mathrm{p}$.

Copeland, P., and Condie, K. C., 1986, Geochemistry and tectonic setting of lower Proterozoic supracrustal rocks of the Pinal Schist, southeastern Arizona: Geological Society of America Bulletin, v. 97, p. 1512-1520.

Cornwall, H. R., and Krieger, M. H., 1975a, Geologic map of the Kearny Quadrangle, Pinal County, Arizona: U.S. Geological Survey Geologic Quadrangle Map GQ-1188, scale 1:24,000 with 9 p. text.

_ , 1975b, Geologic map of the Grayback Quadrangle, Pinal County, Arizona: U.S. Geological Survey Geologic Quadrangle Map GQ-1206, scale 1:24,000 with 2 p. text

—_ 1978, Geologic map of the El Capitan Mountain Quadrangle, Gila and Pinal Counties, Arizona: U.S. Geological Survey Geologic Quadrangle Map GQ-1442, scale 1:24,000.

Cornwall, H. R., Banks, N. G., and Phillips, C. H., 1971, Geologic map of the Sonora Quadrangle, Pinal and Gila Counties, Arizona: U.S. Geological Survey Geologic Quadrangle Ma GQ-1021, scale 1:24,000.

Creasey, S. C., 1965, Geology of the San Manuel area, Pinal County, Arizona: U.S. Geological Survey Professional Paper 471, 64 p.

— , 1967, General geology of the Mammoth Quadrangle, Pinal County, Arizona: U.S. Geological Survey Bulletin 1218, 94 p.

Creasey, S. C., and Krieger, M. H., 1978, Galiuro Volcanics, Pinal, Graham, and Cochise Counties, Arizona: U.S. Geological Survey Journal of Research, v. 6, p. 115-131.

Creasey, S. C., and Theodore, T. G., 1975, Preliminary geologic map of the Bellota Ranch Quadrangle, Pima County, Arizona: U.S. Geological Survey Open-File Report 75-295, scale 1:48,000.

Creasey, S. C., Banks, N. G., Ashley, R. P., and Theodore, T. G., 1977, Middle Tertiary plutonism in the Santa Catalina and Tortolita Mountains: U.S. Geological Survey Journal of Research, v. 5, p. 705-717.

Creasey, S. C., Jinks, J. E., Williams, F. E., and Meaves, H. C., 1981, Mineral resources of the Galiuro Wilderness and contiguous further planning areas, Arizona: U.S. Geological Survey Bulletin 1490, 94 p.

Creasey. S. C., Peterson, D. W., and Gambell, N. A., 1983, Geologic map of the Teapot Mountain Quadrangle, Pinal County, Arizona: U.S. Geological Survey Geologic Quadrangle Map GQ-1559, scale 1:24,000.

Crittenden, M. D., Jr., Coney, P. J., and Davis, G. H., eds., 1980, Cordilleran metamorphic core complexes: Geological Society of America Memoir 153, $490 \mathrm{p}$

Cross, T. A., 1986, Tectonic controls of foreland basin subsidence and Laramide style deformation, western United States, in Allen, P. A., and Homewood, P., eds., Foreland basins: International Association of Sedimentologists Special Publication 8, p. 15-39.

Cross, T. A., and Pilger, R. H., Jr., 1978, Constraints on absolute motion and plate interaction inferred from Cenozoic igneous activity in the western United States: American Journal of Science, v. 278, p. 865-902.

Crowe, B. M., 1978, Cenozoic volcanic geology and probable age of inception of basin-range faulting in the southeasternmost Chocolate Mountains, California: Geological Society of America Bulletin, v. 89, p. 251-264.

Crowe, B. M., Crowell, J. C., and Krummenacher, D., 1979, Regional stratigraphy, $\mathrm{K}-\mathrm{Ar}$ ages, and tectonic implications of Cenozoic volcanic rocks, southeastern California: American Journal of Science, v. 279, p. 186-216.

Damon, P. E., and Bikerman, M., 1964, Potassium-argon dating of post-Laramide plutonic and volcanic rocks within the Basin and Range province of southeastern Arizona and adjacent areas: Arizona Geological Society Digest, v. 12 , p. 63-78.

Damon, P. E., and Mauger, R. L., 1966, Epeirogeny-orogeny viewed from the Basin and Range province: Society of Mining Engineers Transactions, v. 235, p. $99-112$.

Damon, P. E., Mauger, R. L., and Bikerman, M., 1964, K-Ar dating of Laramide plutonic and volcanic rocks within the Basin and Range province of Arizona and Sonora: 22nd International Geological Congress Proceedings, pt. 3, p. $45-55$.

Damon, P. E., Shafiqullah, M., and Clark, K. F., 1981, Age trends of igneous activity in relation to matallogenesis in the southern Cordillera, in Dickinson, W. R., and Payne, W. D., eds., Relations of tectonics to ore deposits in the southern Cordillera: Arizona Geological Society Digest, v. 14, p. 137-154.

Damon, P. E., Shafiqullah, M., and Clark, K. F., 1983, Geochronology of the porphyry copper deposits and related mineralization of Mexico: Canadian Journal of Earth Science, v. 20, p. 1052-1071.

Damon, P. E., Lynch, D. J., and Shafiqullah, M., 1984, Cenozoic landscape development in the Basin and Range province of Arizona, in Smiley, T. L., Nations, J. D., Péwé, T. L., and Schafer, J. P., eds., Landscapes of Arizona: Lanham, Maryland, University Press of America, p. 175-206.

Davidson, E. S., 1973, Geohydrology and water resources of the Tucson Basin, Arizona: U.S. Geological Survey Water-Supply Paper 1939-E, p. E1-E81.

Davis, G. A., 1979, Problems of intraplate extensional tectonics, western United States, with special emphasis on the Great Basin, in Newman, G. W., and Goode, H. D., eds., Basin and Range symposium and Great Basin field conference: Denver, Colorado, Rocky Mountain Association of Geologists, p. 41-54.

1980, Problems of intraplate extensional tectonics, western United States, in Burchfiel, B. C., Oliver, J. E., and Silver, L. T., eds., Continental tectonics: Washington, D.C., National Academy of Sciences, p. 84-95.

, 1988, Rapid upward transport of mid-crustal mylonitic gneisses in the footwall of a Miocene detachment fault, Whipple Mountains, southeastern California: Geologisches Rundschau, v. 77, p. 191-209.

Davis, G. A., and Lister, G. S., 1988, Detachment faulting in continental extension; Perspectives from the southwestern U.S. Cordillera, in Clark, S. P., Jr., Burchfiel, B. C., and Suppe, J., eds., Processes in continental lithospheric deformation: Geological Society of America Special Paper 218, p. 133-159.

Davis, G. A., Anderson, J. L., Frost, E. G., and Shackelford, T. J., 1980, Regional Miocene detachment faulting and early Tertiary(?) mylonitization, WhippleBuckskin-Rawhide Mountains, southeastern California and western Arizona, in Crittenden, M. D., Jr., Coney, P. J., and Davis, G. A., eds., Cordilleran metamorphic core complexes: Geological Society of America Memoir 153, p. 79-129.

Davis, G. A., and 5 others, 1982, Geologic and geochronologic relations in the lower plate of the Whipple detachment fault, Whipple Mountains, southeastern Califronia; A progress report, in Frost, E. G., and Martin, D. L., Mesozoic-Cenozoic tectonic evolution of the Colorado River region, California, Arizona, and Nevada: San Diego, California, Cordilleran Publishers, p. 409-432.

Davis, G. A., Lister, G. S., and Reynolds, R. J., 1986, Structural evolution of the Whipple and South Mountain shear zones, southwestern United States: Geology, v. 14, p. 7-10.

Davis, G. H., 1979, Laramide folding and faulting in southeastern Arizona: American Journal of Science, v. 279, p. 543-569.

_ 1980, Structural characteristics of metamorphic core complexes, southern Arizona, in Crittenden, M. D., Jr., Coney, P. J., and Davis, G. H., eds., Cordilleran metamorphic core complexes: Genlogical Society of America Memoir 153, p. 35-77.

- , 1981, Regional strain analysis of the superposed deformations in southeastern Arizona and the eastern Great Basin, in Dickinson, W. R., and Payne, W. D., eds., Relations of tectonics to ore deposits in the southern Cordillera: Arizona Geological Survey Digest, v. 14, p. 155-172.

, 1983, Shear-zone model for the origin of metamorphic core complexes: Geology, v. 11, p. 342-347.

- 1987, A shear-zone model for the structural evolution of metamorphic core complexes, in Coward, M. P., Dewey, J. F., and Hancock, P. L., eds., Continental extensional tectonics: Geological Society of London Special Publication 28, p. 247-266. 
Davis, G. H., and Coney, P. J., 1979, Geologic development of the Cordilleran metamorphic core complexes: Geology, v. 7, p. 120-124.

Davis, G. H., and Hardy, J. J., Jr., 1981, The Eagle Pass detachment, southeastern Arizona; Product of mid-Miocene listric(?) normal faulting in the southern Basin and Range: Geological Society of America Bulletin, v. 92, p. 749-762.

Davis, G. H., Gardulski, A. F., and Lister, G. S., 1987a, Shear zone origin of quartzite mylonite and mylonitic pegmatite in the Coyote Mountains metamorphic core complex, Arizona: Journal of Structural Geology, v. 9, p. 289-297.

Davis, G. H., Naruk, S. J., and Thorman, C. H., 1987b, Structural geology of the Rincon and Pinaleno metamorphic core complexes, southeast Arizona, in Davis, G. H., and VandenDolder, E. M., eds., Geologic diversity of Arizona and its margins; Excursions to choice areas: Arizona Geological Survey Special Paper 5, p. 249-259.

Deal, E. G., and 6 others, 1978, Cenozoic volcanic geology of the Basin and Range province in Hidalgo County, New Mexico, in Callender, J. F., Wilt, J. C., and Clemons, R. E., eds., Land of Cochise, southeastern Arizona: New Mexico Geological Society 29th Annual Field Conference Guidebook, p. 219-230.

Dethier, D. P., Harrington, C. D., and Aldrich, M. J., 1988, Late Cenozoic rates of erosion in the western Española Basin, New Mexico; Evidence from geologic dating of erosion surfaces: Geological Society of America Bulletin, v. 100 , p. $928-937$.

DeVoogd, B., Serpa, L., and Brown, L., 1988, Crustal extension and magmatic processes; COCORP profiles from Death Valley and the Rio Grande rift: Geological Society of America Bulletin, v. 100, p. 1550-1567.

DeWitt, E., 1980, Comment on geologic development of the Cordilleran metamorphic core complexes: Geology, v. 8, p. 6-7.

Dickinson, W. R., 1979, Cenozoic plate tectonic setting of the Cordilleran region in the western United States, in Armentrout, J. M., Cole, M. R., and TerBest, H., Jr., eds., Cenozoic paleogeography of the western United States: Pacific Section, Society of Economic Paleontologists and Mineralogists Pacific Coast Paleogeography Symposium 3, p. 1-13.

__ , 1981, Plate tectonic evolution of the southern Cordillera, in Dickinson, W. R., and Payne, W. D., eds., Relations of tectonics to ore deposits in the southern Cordillera: Arizona Geological Society Digest, v. 14, p. 113-135.

, 1983, Cretaceous sinistral slip along Nacimiento fault in coastal California: American Association of Petroleum Geologists Bulletin, v. 67, p. 624-645.

— , 1984, Reinterpretation of Lime Peak thrust as a low-angle normal fault Implications for the tectonics of southeastern Arizona: Geology, v. 12, p. 610-613.

- , 1986, Geologic relations in the Kelsey Canyon area, Cochise County, Arizona: Arizona Geological Survey Miscellaneous Map Series MM-86-C, scale $1: 24,000$ with 3 p. text.

_, 1987 , General geologic map of Catalina core complex and San Pedro trough: Arizona Geological Survey Miscellaneous Map Series MM-87-A, scale 1:62,500 (15 open-file map sheets plus 18 p. text).

- , 1988, Geologic map of Catalina core complex and San Pedro trough: Arizona Geological Survey Miscellaneous Map Series MM-88-C, scale 1:125,000.

- 1989 , Tectonic setting of Arizona through geologic time, in Jenney, J. P., and Reynolds, S. J., eds., Geologic evolution of Arizona: Arizona Geological Society Digest, v. 17, p. 1-16.

Dickinson, W. R., and Olivares, M. D., 1987, Reconnaissance geologic map of Mineta Ridge and Banco Ridge area, Pima and Cochise Counties, Arizona: Arizona Geological Survey Miscellaneous Map Series MM-87-C, scale $1: 24,000$ with 3 p. text.

Dickinson, W. R., and Shafiqullah, M., 1989, K-Ar and F-T ages for syntectonic mid-Tertiary volcanosedimentary sequences associated with the Catalina core complex and San Pedro trough in southern Arizona: Isochron/West, no. 52, p. 15-27.

Dickinson, W. R., and Snyder, W. S., 1978, Plate tectonics of the Laramide orogeny, in Matthews, V., III, ed., Laramide folding associated with basement block faulting in the western United States: Geological Society of
America Memoir 151, p. $355-366$.

- , 1979a, Geometry of triple junctions related to San Andreas transform: Journal of Geophysical Research, v. 84, p. 561-572.

_, $1979 \mathrm{~b}$, Geometry of subducted slabs related to San Andreas transform: Journal of Geology, v. 87, p. 609-627.

Dickinson, W. R., Swift, P. N., and Coney, P. J., 1986, Tectonic strip maps of Alpine-Himalayan and Circum-Pacific orogenic belts (great circle projections): Geological Society of America Map and Chart Series MC-58, scale $1: 20,000,000$

Dickinson, W. R., Goodlin, T. C., Grover, J. A., Mark, R. A., and Shafiqullah, M., 1987a, Low-angle normal-fault system along the range front of the southwestern Galiuro Mountains in southeastern Arizona: Geology, v. 15, p. $727-730$.

Dickinson, W. R., Klute, M. A, and Bilodeau, W. L., 1987b, Tectonic setting and sedimentological features of upper Mesozoic strata in southeastern Arizona, in Davis, G. H., and VandenDolder, E. M., eds., Geologic diversity of Arizona and its margins; Excursions to choice areas: Arizona Geological Survey Special Paper 5, p. 266-279.

Dickinson, W. R., and 6 others, 1988, Paleogeographic and paleotectonic setting of Laramide sedimentary basins in the central Rocky Mountain region: Geological Society of America Bulletin, v. 100, p. 1023-1039.

Dickinson, W. R., and 5 others, 1989, Cretaceous strata of southern Arizona, in Jenney, J. P., and Reynolds, S. J., eds., Geologic evolution of Arizona: Arizona Geological Society Digest, v. 17, p. 447-461.

DiTullio, L. D., 1983, Fault rocks of the Tanque Verde Mountain decollement zone, Santa Catalina metamorphic core complex, Tucson Arizona [M.S. thesis]: Tucson, University of Arizona, $90 \mathrm{p}$.

Dokka, R. K., 1986, Patterns and modes of early Miocene crustal extension, central Mojave Desert, California, in Mayer, L., ed., Extensional tectonics of the southwestern United States; A perspective on processes and kinematics: Geological Society of America Special Paper 208, p. 75-96.

_ 1989, The Mojave extensional belt of southern California: Tectonics, v. 8 , p. $363-390$.

Dokka, R. K., and Merriam, R. H., 1982, Late Cenozoic extension of northeastern Baja California, Mexico: Geological Society of America, v. 93, p. $371-378$.

Dokka, R. K., McCurry, M., Woodburne, W. O., Frost, E. G. and Okaya, D. A., 1988, A field guide to the Cenozoic crustal structure of the Mojave Desert, in Weide, D. L., and Faber, M. L., eds., This extended land; Geological journeys in the southern Basin and Range: Las Vegas, University of Nevada, Department of Geoscience Special Publication 2, p. 21-44.

Drewes, H. D., 1974, Geologic map and sections of the Happy Valley Quadrangle, Cochise County, Arizona: U.S. Geological Survey Miscellaneous Investigations Series Map I-832, scale 1:48,000.

_ , 1976, Laramide tectonics from Paradise to Hells Gate, southeastern Arizona: Arizona Geological Society Digest, v. 10, p. 151-168.

_ 1977, Geologic map and sections of the Rincon Valley Quadrangle, Pima County, Arizona: U.S. Geological Survey Miscellaneous Investigations Series Map I-997, scale 1:48,000.

_ 1978, The Cordilleran orogenic belt between Nevada and Chihuahua: Geological Society of America Bulletin, v. 89, p. 641-657.

_ 1981, Tectonics of southeastern Arizona: U.S. Geological Survey Professional Paper 1144, $96 \mathrm{p}$.

Duffield, W. A., and McKee, E. H., 1986, Geochronology, structure, and basinrange tectonism of the Warner Range, northeastern California: Geological Society of America Bulletin, v. 97, p. 142-146.

Duncan, R. A., 1982, A captured island chain in the Coast Range of Oregon and Washington: Journal of Geophysical Research, v. 87, p. 10827-10837.

Dunne, L. A., and Hempton, M. R., 1984, Deltaic sedimentation in the Lake Hazar pull-apart basin, south-eastern Turkey: Sedimentology, v. 31, p. $401-412$.

Eaton, G. P., 1979, A plate-tectonic model for late Cenozoic crustal spreading in the western United States, in Riecker, R. E., ed., Rio Grande rift; Tectonics and magmatism: Washington, D.C., American Geophysical Union, p. 7-32. 
_ , 1980, Geophysical and geological characteristics of the crust of the Basin and Range province, in Burchfiel, B. C., Oliver, J. E., and Silver, L. T., eds., Continental tectonics: Washington, D.C., National Academy of Sciences, p. 96-113.

- , 1982, The Basin and Range province; Origin and tectonic significance: Annual Reviews of Earth and Planetary Sciences, v. 10, p. 409-440.

- , 1984, The Miocene Great Basin of western North America as an extending back-arc region: Tectonophysics, v. 102, p. 275-295.

Eberly, L. D., and Stanley, T. B., Jr., 1978, Cenozoic stratigraphy and geologic history of southwestern Arizona: Geological Society of America Bulletin, v. 89 , p. $921-940$.

Ekren, E. B., and Byers, F. M., Jr., 1984, The Gabbs Valley Range, a wellexposed segment of the Walker Lane in western Nevada, in Lintz, J., ed., Western geological excursions, Volume 4: Reno, University of Nevada, MacKay School of Mines, p. 203-219.

Elston, W. E., 1976, Tectonic significance of mid-Tertiary volcanism in the Basin and Range province; A critical review with special reference to New Mexico, in Elston, W. E., and Northrop, S. A., eds., Cenozoic volcanism in southwestern New Mexico: New Mexico Geological Society Special Publication 5, p. 93-102.

- 1984, Subduction of young lithosphere and extensional orogeny in southwestern New Mexico during mid-Tertiary time: Tectonics, v. 3, p. 229-250. , 1989, Overview of the Mogollon-Datil volcanic field, in Chapin, C. E., and Zidek, J., eds., Field excursions to volcanic terranes in the western United States; Volume 1, Southern Rocky Mountain region: New Mexico Bureau of Mines and Mineral Resources Memoir 46, p. 43-46.

Elston, W. E., and Bornhorst, T. J., 1979, The Rio Grande rift in context of regional post-40 m.y. volcanic and tectonic events, in Riecker, R. E., ed., Rio Grande rift; Tectonics and magmatism: Washington, D.C., American Geophysical Union, p. 416-438.

Elston, W. E., and 5 others, 1973, Tertiary volcanic rocks, Mogollon-Datil province, New Mexico, and surrounding region; K-Ar dates, patterns of eruption, and periods of mineralization: Geological Society of America Bulletin, v. 84, p. 2259-2274.

Elston, W. E., Rhodes, R. C., Coney, P. J., and Deal, E. G., 1976, Progress report on the Mogollon Plateau volcanic field, southwestern New Mexico, in Elston, W. E., and Northrop, S. A., eds., Cenozoic volcanism in southwestern New Mexico: New Mexico Geological Society Special Publication 5, p. 3-28.

England, P. C., and Jackson, J. A., 1987, Migration of the seismic-aseismic transition during uniform and nonuniform extension of the continental lithosphere: Geology, v. 15, p. 291-294.

Ewing, T. E., 1980, Paleogene tectonic evolution of the Pacific Northwest: Journal of Geology, v. 88, p. 619-638.

- 1981, Petrology and geochemistry of the Kamloops Group volcanics, British Columbia: Canadian Journal of Earth Sciences, v. 18, p. 1478-1491.

Farmer, G. L., and DePaolo, D. J., 1984, Origin of Mesozoic and Tertiary granite in the western United States and implications for pre-Mesozoic crustal structures; 2, $\mathrm{Nd}$ and $\mathrm{Sr}$ isotopic studies of unmineralized and $\mathrm{Cu}-$ and $\mathrm{Mo}-$ mineralized granite in the Precambrian craton: Journal of Geophysical Research, v. 89, p. 10141-10160.

Faulds, J. E., Hillemeyer, F. L., and Smith, E. I., 1988, Geometry and kinematics of a Miocene "accommodation zone" in the central Black and southern Eldorado Mountains, Arizona and Nevada, in Weide, D. L., and Faber, M. L., eds., This extended land; Geological journeys in the southern Basin and Range: Las Vegas, University of Nevada, Department of Geoscience Special Publication 2, p. 293-310.

Fields, R. W., Rasmussen, D. L., Tabrum, A. R., and Nichols, R., 1985, Cenozoic rocks of the intermontane basins of western Montana and eastern Idaho, in Flores, R. M., and Kaplan, S. S., eds., Cenozoic paleogeography of the west-central United States: Rocky Mountain Section, Society of Economic Paleontologists and Mineralogists Rocky Mountain Paleogeography Symposium 3, p. 9-36.

Finnell, T. L., 1970, Pantano Formation: U.S. Geological Survey Bulletin 1294-A, p. A35-A36.

Fleck, R. J., 1970, Age and tectonic significance of volcanic rocks, Death Valley area, California: Geological Society of America Bulletin, v. 81, p. 2807-2816.

Flint, S., Clemmey, H., and Turner, P., 1986, The Lower Cretaceous Way Group of northern Chile; An alluvial fan-fan delta complex: Sedimentary Geology, v. 46, p. 1-22.

Frei, L. S., 1986, Additional paleomagnetic results from the Sierra Nevada; Further constraints on Basin and Range extension and northward displacement in the western United States: Geological Society of America Bulletin, v. 97 , p. $840-849$.

Frei, L. S., Magill, J. R., and Cox, A., 1984, Paleomagnetic results from the central Sierra Nevada; Constraints on reconstructions of the western United States: Tectonics, v. 3, p. 157-177.

Friedman, R. M., and Armstrong, R. L., 1988, Tatla Lake metamorphic complex; An Eocene metamorphic core complex on the southwestern edge of the intermontane belt of British Columbia: Tectonics, v. 7, p. 1141-1166.

Frost, E. G., 1981, Structural style of detachment faulting in the Whipple Mountains, California, and Buckskin Mountains, Arizona: Arizona Geological Society Digest, v. 13, p. 25-29.

Fryxell, J. E., Stimac, J. A., and Reynolds, S. J., 1987, Superimposed dominostyle normal faults in a Tertiary bimodal volcanic complex, Wickenburg Mountains and vicinity, central Arizona: Geological Society of America Abstracts with Programs, v. 19, p. 670.

Gager, B. R., 1984, The Tiger Formation; Paleogene fluvial sediments deposited adjacent to a deforming Cordilleran metamorphic core complex, northeastern Washington: Sedimentary Geology, v. 38, p. 393-340.

Gans, P. B., 1987, An open-system, two-layer crustal stretching model for the eastern Great Basin: Tectonics, v. 6, p. 1-12.

Gans, P. B., and Miller, E. L., 1983, Style of mid-Tertiary extension in east-central Nevada: Utah Geological and Mineral Survey Special Studies 59, p. 107-158.

Gans, P. B., Miller, E. L., McCarthy, J., and Ouldcott, M. L., 1985, Tertiary extensional faulting and evolving brittle-ductile transition zones in the northern Snake Range and vicinity; New insights from seismic data: Geology, v. 13, p. 189-193.

Gans, P. B., Lee, J., Miller, E. L., Kunk, M., and Sutter, J. F., 1988, Uplift history of mid-crustal rocks in the eastern Great Basin: Geological Society of America Abstracts with Programs, v. 20, p. A17.

Gans, P. B., Mahood, G. A., and Schermer, E., 1989, Synextensional magmatism in the Basin and Range province; A case study from the eastern Great Basin: Geological Society of America Special Paper 233, $58 \mathrm{p}$.

Gardner, J. N., and Goff, F., 1984, Potassium-argon dates from the Jemez volcanic field; Implications for tectonic activity in the north-central Rio Grande rift, in Baldridge, W. S., Dickerson, P. W., Riecker, R. E., and Zidek, J., eds., Rio Grande rift; Northern New Mexico: New Mexico Geological Society 35th Annual Field Conference Guidebook, p. 75-81.

Gardner, J. N., Goff, F., Garcia, S., and Hagan, R. C., 1986, Stratigraphic relations and lithologic variations in the Jemez volcanic field, New Mexico: Journal of Geophysical Research, v. 91, p. 1763-1778.

Gastil, G., Krummenacher, D., and Minch, J., 1979, The record of Cenozoic volcanism around the Gulf of California: Geological Society of America Bulletin, v. 90, p. 839-857.

Gay, S. P., 1989, Gravitational compaction; A neglected mechanism in structural and stratigraphic studies; New evidence from Mid-Continent, USA: American Association of Petroleum Geologists Bulletin, v. 73, p. 641-657.

Gehrels, G. E., and Smith, C. H., 1990, U-Pb (zircon and monazite) ages of thrusting and peraluminous plutonism in the eastern Rincon Mountains, southern Arizona: Geological Society of America Abstracts with Programs, v. 22, p. 25 .

_ , 1991, U-Pb geochronologic constraints on the age of thrusting and peraluminous plutonism in the eastern Rincon Mountains, southern Arizona: Geology, v. 19, p. 238-241.

Gibbs, A. D., 1984, Structural evolution of extensional basin margins: Geological 
Society of London Journal, v. 141, p. 609-620.

Gilbert, C. M., and Reynolds, M. W., 1973, Character and chronology of basin development, western margin of the Basin and Range province: Geological Society of America Bulletin, v. 84, p. 2489-2510.

Gilbert, C. M., Christensen, M. N., Al-Rawi, Y., and Lajoie, K. R., 1968, Structural and volcanic history of Mono Basin, California-Nevada, in Coats, R. R., Hay, R. L., and Anderson, C. A., eds., Studies in volcanology: Geological Society of America Memoir 116, p. 275-329.

Gilbert, G. K., 1875, Report on the geology of portions of New Mexico and Arizona: U.S. Geographical and Geological Survey West of the 100th Meridian (Wheeler Survey), v. 3, p. 501-567.

Glazner, A. F., 1988, Stratigraphy, structure, and potassic alteration of Miocene volcanic rocks in the Sleeping Beauty area, central Mojave Desert, California: Geological Society of America Bulletin, v. 100, p. 424-435.

Glazner, A. F., and Supplee, J. A., 1982, Migration of Tertiary volcanism in the southwestern United States and subduction of the Mendocino fracture zone: Earth and Planetary Science Letters, v. 60, p. 429-436.

Glazner, A. F., and Bartley, J, M., 1984, Timing and tectonic setting of Tertiary low-angle normal faulting and associated magmatism in the southwestern United States: Tectonics, v. 3, p. 385-396.

Glazner, A. F., Neilson, J. E., Howard, K. A., and Miller, D. M., 1986, Correlation of the Peach Springs Tuff, a large-volume Miocene ignimbrite sheet in California and Arizona: Geology, v. 14, p. 840-843.

Glazner, A. F., Bartley, J. M., and Walker, J. D., 1988, Geology of the Waterman Hills detachment fault, central Mojave Desert, California, in Weide, D. L., and Faber, M. L., eds., This extended land; Geological journeys in the southern Basin and Range: Las Vegas, University of Nevada, Department of Geoscience Special Publication 2, p. 225-237.

— 1989, Magnitude and significance of Miocene crustal extension in the central Mojave Desert, California: Geology, v. 17, p. 50-53.

Gloppen, T. G., and Steel, R. J., 1981, The deposits, internal structure, and geometry in six alluvial fan-fan delta bodies (Devonian, Norway); A study in the significance of bedding sequence in conglomerate, in Ethridge, F. G., and Flores, R. M., eds., Recent and ancient nonmarine depositional environments; Models for exploration: Society of Economic Paleontologists and Mineralogists Special Publication 31, p. 49-69.

Golia, R. T., and Stewart, J. H., 1984, Depositional environments and paleogeography of the Upper Miocene Wassuk Group, west-central Nevada: Sedimentary Geology, v. 38, p. 159-180.

Goodlin, T. C., and Mark, R. A., 1987, Tectonic implications of stratigraphy and structure of Cretaceous rocks and overlying mid-Tertiary cover in Hot Springs Canyon, Galiuro Mountains, southeastern Arizona, in Dickinson, W. R., and Klute, M. A., eds., Mesozoic rocks of southern Arizona and adjacent areas: Arizona Geological Society Digest, v. 18, p. 177-188.

Gray, R. S., 1965, Late Cenozoic sediments of the San Pedro Valley near St. David, Arizona [Ph.D. thesis]: Tucson, University of Arizona, 198 p.

- 1967, Petrography of the upper Cenozoic non-marine sediments in the San Pedro Valley, Arizona: Journal of Sedimentary Petrology, v. 37, p. 774-789.

Grier, S., 1983, Tertiary stratigraphy and geologic history of the Sacramento Pass area, Nevada: Utah Geological and Mineral Survey Special Studies 59, p. 139-144.

Groat, C. G., 1972, Presidio bolson, Trans-Pecos Texas and adjacent Mexico; Geology of a desert basin aquifer system: Texas Bureau of Economic Geology Report of Investigations 76, $46 \mathrm{p}$.

Gromme, C. S., Beck, M. E., Jr., Wells, R. E., and Engebretson, D. C., 1986, Paleomagnetism of the Tertiary Clarno Formation of central Oregon and its significance for the tectonic history of the Pacific Northwest: Journal of Geophysical Research, v. 991, p. 14089-14103.

Grover, J. A., 1982, The geology of Teran Basin, Cochise County, Arizona [M.S. thesis]: Tucson, University of Arizona, $73 \mathrm{p}$.

- 1984, Petrology, depositional environments, and structural development of the Mineta Formation, Teran Basin, Cochise County, Arizona: Sedimentary Geology, v. 38, p. 87-105.

Gunderson, R., Cameron, K., and Cameron, M., 1986, Mid-Cenozoic high-K calc-alkalic and alkalic volcanism in eastern Chihuahua, Mexico; Geology and geochemistry of the Benavides-Pozos area: Geological Society of America Bulletin, v. 97, p. 737-753.

Hamblin, W. K., 1965, Origin of "reverse drag" on the downthrown side of normal faults: Geological Society of America Bulletin, v. 76, p. 1145-1164.

Hamilton, W., 1982, Structural evolution of the Big Maria Mountains, northeastern Riverside County, southeastern California, in Frost, E. G., and Martin, D. L., eds., Mesozoic-Cenozoic tectonic evolution of the Colorado River region, California, Arizona, and Nevada: San Diego, California, Cordilleran Publishers, p. 1-27.

, 1987, Crustal extension in the Basin and range province, southwestern United States, in Coward, M. P., Dewey, J. F., and Hancock, P. L., eds., Continental extensional tectonics: Geological Society of London Special Publication 28, p. 155-176.

_ 1988a, Tectonic setting and variations with depth of some Cretaceous and Cenozoic structural and magmatic systems of the western United States, in Ernst, W. G., ed., Metamorphism and crustal evolution of the western United States; Rubey Volume 7: Englewood Cliffs, New Jersey, Prentice-Hall, p. $1-40$.

_, $1988 \mathrm{~b}$, Plate tectonics and island arcs: Geological Society of America Bulletin, v. 100, p. $1503-1527$.

Hansen, J. B., 1983, Style of deformation of upper plate rocks of the San ManuelCamp Grant low-angle normal fault system, Black Hills, Pinal County, Arizona [M.S. thesis]: Tucson, University of Arizona, 164 p.

Hansen, V. L., and Goodge, J. W., 1988, Metamorphism, structural petrology, and regional evolution of the Okanagan complex, northeastern Washington, in Ernst, W. G., ed., Metamorphism and crustal evolution of the western United States; Rubey Volume 7: Englewood Cliffs, New Jersey, PrenticeHall, p. 233-270.

Hardie, L. A., Smoot, J. P., and Eugster, H. P., 1978, Saline lakes and their deposits; A sedimentological approach, in Matter, A., and Tucker, M. E., eds., Modern and ancient lake sediments: International Association of Sedimentologists Special Publication 2, p. 7-41.

Hardyman, R. F., 1984, Strike-slip, normal, and detachment faults in the northern Gillis Range, Walker Lane of west-central Nevada, in Lintz, J., Jr., ed., Western geological excursions, Volume 4: Reno, University of Nevada Mackay School of Mines, p. 184-203.

Hart, W. K., and Carlson, R. W., 1985, Distribution and geochronology of Steens Mountain-type basalts from the northwestern Great Basin: Isochron/West, no. 43 , p. $5-10$.

Hauser, E. C., and Lundy, J., 1989, COCORP deep reflections; Moho at $50 \mathrm{~km}$ (16 s) beneath the Colorado Plateau: Journal of Geophysical Research, v. 94, p. 7071-7081.

Haxel, G. B., Tosdal, R. M., May, D. J., and Wright, J. E., 1984, Latest Cretaceous and early Tertiary orogenesis in south-central Arizona; Thrust faulting, regional metamorphism, and granitic plutonism: Geological Society of America Bulletin, v. 95, p. 631-653.

Hayes, M. J., 1987, Depositional history of Upper Cretaceous Fort Crittenden Formation in southeastern Arizona, in Dickinson, W. R., and Klute, M. A., eds., Mesozoic rocks of southern Arizona and adjacent areas: Arizona Geological Society Digest, v. 18, p. 315-325.

Heidrick, T. L., and Titley, S. R., 1982, Fracture and dike patterns in Laramide plutons and their structural and tectonic implications, in Titley, S. R., ed., Advances in geology of the porphyry copper deposits, southwestern North America: Tucson, University of Arizona Press, p. 73-91.

Heindl, L. A., 1958, Cenozoic alluvial deposits of the upper Gila River area, New Mexico and Arizona [Ph.D. thesis]: Tucson, University of Arizona, 249 p.

— 1963, Cenozoic geology in the Mammoth area, Pinal County, Arizona: U.S. Geological Survey Bulletin 1141-E, p. E1-E41.

Heller, P. L., and Ryberg, P. T., 1983, Sedimentary record of subduction to forearc transition in the rotated Eocene basin of western Oregon: Geology, v. 11, p. $380-383$.

Heller, P. L., Tabor, R. W., and Suczek, C. A., 1987, Paleogeographic evolution of the United States Pacific Northwest during Paleogene time: Canadian 
Journal of Earth Sciences, v. 24 p. 1652-1667.

Hendrix, E. D., and Ingersoll, R. V., 1987, Tectonics and alluvial sedimentation of the upper Oligocene/lower Miocene Vasquez Formation, Soledad basin, southern California: Geological Society of America Bulletin, v. 98, p. 647-663.

Henry, C. D., 1989, Late Cenozoic Basin and Range structure in western Mexico adjacent to the Gulf of California: Geological Society of America Bulletin, v. 101, p. 1147-1156.

Henry, C. D., and Price, J. G., 1984, Variations in caldera development in the Tertiary volcanic field of Trans-Pecos Texas: Journal of Geophysical Research, v. 89 , p. 8765-8786.

-__ 1986, Early Basin and Range development in Trans-Pecos Texas and adjacent Chihuahua; Magmatism and orientation, timing, and style of extension: Journal of Geophysical Research, v. 91, p. 6213-6224.

Henry, C. D., Price, J. G., and McDowell, F. W., 1983, Presence of the Rio Grande Rift in west Texas and Chihuahua, in Clark, K. F., and Goodell, P. C., eds., Geology and mineral resources of north-central Chihuahua: El Paso Geological Society Publication 15, p. 108-118.

Henry, C. D., Price, J. G., Parker, D. F., and Wolff, J. A., 1989, Mid-Tertiary silicic alkalic magmatism of Trans-Pecos Texas; Rheomorphic tuffs and extensive silicic lavas, in Chapin, C. E., and Zidek, J., eds., Field excursions to volcanic terranes in the western United States; Volume 1, Southern Rocky Mountain region: New Mexico Bureau of Mines and Mineral Resources Memoir 46, p. 231-274.

Heward, A. P., 1978, Alluvial fan sequence and megasequence models, in Miall, A. D., ed., Fluvial sedimentology: Canadian Society of Petroleum Geologists Memoir 5, p. 669-702.

Hodges, K. V., and 8 others, 1989, Evolution of extensional basins and Basin and Range topography west of Death Valley, California: Tectonics, v. 8, p. 453-467.

Holt, W. E., Chase, C. G., and Wallace, T. C., 1986, Crustal structure from three-dimensional gravity modeling of a metamorphic core complex; A model for uplift, Santa Catalina-Rincon Mountains, Arizona: Geology, v. 14, p. $927-930$.

Hooper, P. R., 1982, The Columbia River basalts: Science, v. 215, p. 1463-1468.

__ , 1988, The Columbia River Basalt, in Macdougall, J. D., ed., Continental flood basalts: Dordrecht, Holland, Kluwer Academic Publishers, p. 1-33.

Howard, K. A., 1991, Intrusion of horizontal dikes; Tectonic significance of middle Proterozoic diabase sheets widespread in the upper crust of the southwestern United States: Journal of Geophysical Research, v. 96 (in press).

Howard, K. A., and John, B. E., 1987, Crustal extension along a rooted system of imbricate low-angle faulting; Colorado River extensional corridor, California and Arizona, in Coward, M. P., Dewey, J. F., and Hancock, P. L., eds., Continental extensional tectonics: Geological Society of London Special Publication 28, p. 299-311.

Howard, K. A., Goodge, J. W., and John, B. E., 1982a, Detached crystalline rocks of the Mohave, Buck, and Bill Williams Mountains, western Arizona, in Frost, E. G., and Martin, D. L., eds., Mesozoic-Cenozoic tectonic evolution of the Colorado River region, California, Arizona, and Nevada: San Diego, California, Cordilleran Publishers, p. 377-390.

Howard, K. A., Stone, P., Pernokas, M. A., and Marvin, R. F., 1982b, Geologic and geochronologic reconnaissance of the Turtle Mountains area, California, in Frost, E. G., and Martin, D. L., eds., Mesozoic-Cenozoic tectonic evolution of the Colorado River region, California, Arizona, and Nevada: San Diego, California, Cordilleran Publishers, p. 341-354.

Hsu, K. J., 1975, Catastrophic debris streams (sturzstroms) generated by rockfalls: Geological Society of America Bulletin, v. 86, p. 129-140.

Hubert, J. F., and Hyde, M. G., 1982, Sheet-flow deposits of graded beds and mudstones on an alluvial sandflat-playa system; Upper Triassic Blomidon redbeds, St. Mary's Bay, Nova Scotia: Sedimentology, v. 29, p. 457-474.

Hubert, J. F., Reed, A. A., and Carey, P. J., 1976, Paleogeography of the East Berlin Formation, Newark Group, Connecticut Valley: American Journal of Science, v. 276, p. 1183-1207.
Hurlow, H. A., Snoke, A. W., and Hodges, K. V., 1991, Temperature and pressure of mylonitization in a Tertiary extensional shear zone, Ruby Mountains-East Humboldt Range, Nevada; Tectonic implications: Geology, v. 19, p. 82-86.

Ingersoll, R. V., 1982, Triple-junction instability as a cause for late Cenozoic extension and fragmentation of the western United States: Geology, v. 10, p. 621-624.

Ingersoll, R. V., Cavazza, W., Baldridge, W. S., and Shafiqullah, M., 1990, Cenozoic sedimentation and paleotectonics of north-central New Mexico; Implications for initiation and evolution of the Rio Grande rift: Geological Society of America Bulletin, v. 102, p. 1280-1296.

Jackson, J. A., 1987, Active normal faulting and crustal extension, in Coward, M. P., Dewey, J. F., and Hancock, P. L., eds., Continental extensional tectonics: Geological Society of London Special Publication 28, p. 3-17.

Jackson, J. A., and McKenzie, D., 1983, The geometrical evolution of normal fault systems: Journal of Structural Geology, v. 5, p. 471-482.

Jackson, J. A., and White, N. J., 1989, Normal faulting in the upper continental crust; Observations from region of active extension: Journal of Structural Geology, v. 11, p. 15-36.

Jackson, J. A., White, N. J., Garfunkel, Z., and Anderson, H., 1988, Relations between normal-fault geometry, tilting, and vertical motions in extensional terrains; An example from southern Gulf of Suez: Journal of Structural Geology, v. 10, p. 155-170.

Janecke, S. U., 1986, Pre-Eocene structural history of the northern Santa Catalina metamorphic core complex, southeastern Arizona [M.S. thesis]: Tucson, University of Arizona, $151 \mathrm{p}$.

, 1987, Mesozoic and early Tertiary structural history of the Geesaman Wash area, northeastern Catalina-Rincon metamorphic core complex, in Dickinson, W. R., and Klute, M. A., eds., Mesozoic rocks of southern Arizona and adjacent areas: Arizona Geological Society Digest, v. 18, p. 189-201.

Jansen, L. J., 1982, Stratigraphy and structure of the Mission copper deposit, Pima Mining District, Pima County, Arizona, in Titley, S. R., ed., Advances in geology of the porphyry copper deposits, southwestern North America: Tucson, University of Arizona Press, p. 467-474.

John, B. E., 1982, Geologic framework of the Chemehuevi Mountains, southeastern California, in Frost, E. G., and Martin, D. L., eds., Mesozoic-Cenozoic tectonic evolution of the Colorado River region, California, Arizona, and Nevada: San Diego, California, Cordilleran Publishers, p. 317-325.

- 1987, Geometry and evolution of a mid-crustal extensional fault system, Chemehuevi Mountains, southeastern California, in Coward, M. P., Dewey, J. F., and Hancock, P. L., eds., Continental extensional tectonics: Geological Society of London Special Publication 28, p. 313-335.

John, B. E., and Mukasa, S. B., 1990, Footwall rocks to the mid-Tertiary Chemehuevi detachment fault; A window into the middle crust in the southern Cordillera: Journal of Geophysical Research, v. 95, p. 463-485.

Johnson, C. M., and Lipman, P. W., 1988, Origin of metaluminous and alkaline volcanic rocks of the Latir volcanic field, northern Rio Grande rift, New Mexico: Contributions to Mineralogy and Petrology, v. 100, p. 107-128.

Johnson, N. M., Opdyke, N. D., and Lindsay, E. H., 1975, Magnetic polarity stratigraphy of Pliocene-Pleistocene terrestrial deposits and vertebrate faunas, San Pedro Valley, Arizona: Geological Society of America Bulletin, v. 86, p. 5-12.

Keith, S. B., 1978, Paleosubduction geometries inferred from Cretaceous and Tertiary magmatic patterns in southwestern North America: Geology, v. 6, p. $516-521$.

- 1982, Paleoconvergence rates determined from $\mathrm{K}_{2} \mathrm{O}-\mathrm{SiO}_{2}$ ratios in magmatic rocks and their application to Cretaceous and Tertiary tectonic patterns in southwestern North America: Geological Society of America Bulletin, v. 93, p. 524-532.

_ , 1984, Map of outcrops of Laramide (Cretaceous-Tertiary) rocks in Arizona and adjacent regions: Tucson, Arizona Bureau of Geology and Mineral Technology, scale 1:1,000,000.

, 1986, A contribution to the geology and tectonics of the Ray-Superior 
region, Pinal County, Arizona, in Reatty, B., and Wilkinson, P.A.K., eds., Frontiers in geology and ore deposits of Arizona and the Southwest: Arizona Geological Society Digest, v. 16, p. 392-407.

Keith, S. B., and Wilt, J. C., 1985, Late Cretaceous and Cenozoic orogenesis of Arizona and adjacent regions; A stratotectonic approach, in Flores, R. M., and Kaplan, S. S., eds., Cenozoic paleogeography of the west-central United States: Rocky Mountain Section, Society of Economic Paleontologists and Mineralogists Rocky Mountain Paleogeography Symposium 3, p. 403-438.

— , 1986, Laramide orogeny in Arizona and adjacent regions, in Beatty, B., and Wilkinson, P.A.K., eds., Frontiers in geology and ore deposits of Arizona and the Southwest: Arizona Geological Society Digest, v. 16, p. 502-554.

Keith, S. B., and 5 others, 1980, Evidence for multiple intrusion and deformation within the Santa Catalina-Rincon-Tortolita crystalline complex, southeastern Arizona, in Crittenden, M. D., Jr., Coney, P. J., and Davis, G. H., eds., Cordilleran metamorphic core complexes: Geological Society of America Memoir 153, p. 217-267.

Kent, P. E., 1966, The transport mechanism in catastrophic rock falls: Journal of Geology, v. 74, p. 79-83.

Kerrich, R., 1988, Detachment zones of Cordilleran metamorphic core complexes; Thermal, fluid, and metamorphic regimes: Geologisches Rundschau, v. 77 , p. $157-182$.

Kerrich, R., and Rehrig, W., 1987, Fluid motion associated with Tertiary mylonitization and detachment faulting; ${ }^{18} \mathrm{O} /{ }^{16} \mathrm{O}$ evidence from the Picacho metamorphic core complex, Arizona: Geology, v. 15, p. 58-62.

King, J. R., 1982, Geology of the San Xavier North porphyry copper deposit, Pima Mining District, Pima County, Arizona, in Titley, S. R., ed., Advances in geology of the porphyry copper deposits, southwestern North America: Tucson, University of Arizona Press, p. 475-485.

Krantz, R. W., 1983, Detailed structural analysis of detachment faulting near Colossal Cave, southern Rincon Mountains, Arizona [M.S. thesis]: Tucson, University of Arizona, $58 \mathrm{p}$.

Krieger, M. H., 1961, Troy Quartzite (younger Precambrian) and Bolsa and Abrigo Formations (Cambrian), northern Galiuro Mountains, southeastern Arizona: U.S. Geological Survey Professional Paper 424-C, p. C160-C164.

— , 1968a, Stratigraphic relations of the Troy Quartzite (younger Precambrian) and the Cambrian formations in southeastern Arizona, in Titley, S. R., ed., Southern Arizona Guidebook 3: Tucson, Arizona Geological Society, p. 23-32.

__ , 1968b, Geologic map of the Brandenburg Mountain Quadrangle, Pinal County, Arizona: U.S. Geological Survey Geologic Quadrangle Map GQ668 , scale $1: 24,000$ with 3 p. text.

— , 1968c, Geologic map of the Holy Joe Peak Quadrangle, Pinal County, Arizona: U.S. Geological Survey Geologic Quadrangle Map GQ-669, scale 1:24,000 with $4 \mathrm{p}$. text.

— , 1968d, Geologic map of the Lookout Mountain Quadrangle, Pinal County, Arizona: U.S. Geological Survey Geologic Quadrangle Map GQ670 , scale $1: 24,000$ with 2 p. text.

- 1968e, Geologic map of the Saddle Mountain Quadrangle, Pinal County, Arizona: U.S. Geological Survey Geologic Quadrangle Map GQ-671, scale 1:24,000 with 3 p. text.

— , 1974a, Generalized geology and structure of the Winkelman 15-minute Quadrangle and vicinity, Pinal and Gila Counties, Arizona: U.S. Geological Survey Journal of Research, v. 2, p. 311-321.

— , 1974b, Geologic map of the Winkelman Quadrangle, Pinal and Gila Counties, Arizona: U.S. Geological Survey Geologic Quadrangle Map GQ1106 , scale $1: 24,000$ with 8 p. text.

-_ 1974c, Geologic map of the Crozier Peak Quadrangle, Pinal County, Arizona: U.S. Geological Survey Geologic Quadrangle Ma GQ-1107, scale 1:24,000 with 11 p. text.

_ , 1974d, Geologic map of the Black Mountain Quadrangle, Pinal County, Arizona: U.S. Geological Survey Geologic Quadrangle Map GQ-1108, scale $1: 24,000$ with 4 p. text.

— $1974 \mathrm{e}$, Geologic map of the Putnam Wash Quadrangle, Pinal County,
Arizona: U.S. Geological Survey Geologic Quadrangle Map GQ-1109, scale 1:24,000 with $7 \mathrm{p}$. text.

— , 1977, Large landslides, composed of megabreccia, interbedded in Miocene basin deposits, southeastern Arizona: U.S. Geological Survey Professional Paper 1008, $25 \mathrm{p}$.

_ , 1979, Ash-flow tuffs of the Galiuro Volcanics in the northern Galiuro Mountains, Pinal County, Arizona: U.S. Geological Survey Professional Paper 1104, $32 \mathrm{p}$.

Krieger, M. H., Cornwall, H. R., and Banks, N. G., 1974, Big Dome Formation and revised Tertiary stratigraphy in the Ray-San Manuel area, Arizona: U.S. Geological Survey Bulletin 1394-A, p. A54-A62.

Lachenbruch, A. H., and Sass, J. H., 1978, Models of an extending lithosphere and heat flow in the Basin and Range province, in Smith, R. B., and Eaton, G. P., eds., Cenozoic tectonics and regional geophysics of the western Cordillera: Geological Society of America Memoir 152, p. 209-250.

Ladd, T. W., 1975, Stratigraphy and petrology of the Quiburis Formation near Mammoth, Pinal County, Arizona [M.S. thesis]: Tucson, University of Arizona, $103 \mathrm{p}$.

Langlois, J. D., 1978, Geology of the Cyprus Pima mine, Pima County, Arizona: Arizona Geological Society Digest, v. 11, p. 103-113.

Leeder, M. R., and Gawthorpe, R. L., 1987, Sedimentary models for extensional tilt-block/half-graben basins, in Coward, M. P., Dewey, J. F., and Hancock, P. L., eds., Continental extensional tectonics: Geological Society of London Special Publication 28, p. 139-152.

Leonard, B. F., and Marvin, R. F., 1982, Temporal evolution of the Thunder Mountain caldera and related features, central Idaho, in Bonnichsen, B., and Breckenridge, R. M., eds., Cenozoic geology of Idaho: Idaho Bureau of Mines and Geology Bulletin 26, p. 23-41.

LePichon, X., and Sibuet, J-C., 1981, Passive continental margins; A model of formation: Journal of Geophysical Research, v. 86, p. 3708-3720.

Lindsay, E. H., Opdyke, N. D., and Johnson, N. M., 1984, Blancan-Hemphillian land mammal ages and late Cenozoic mammal dispersal events: Annual Reviews of Earth and Planetary Science, v. 12, p. 445-488.

___ , 1987, Late Cenozoic deposits, vertebrate faunas, and magnetostratigraphy of southeastern Arizona, in Davis, G. H., and VandenDolder, E. M., eds., Geologic diversity of Arizona and its margins; Excursions to choice areas: Arizona Geological Survey Special Paper 5, p. 227-237.

Lindsay, E. H., Smith, G. A., Haynes, C. V., and Opdyke, N. D., 1990, Sediments, geomorphology, magnetostratigraphy, and vertebrate paleontology in the San Pedro Valley, Arizona: Journal of Geology, v. 98, p. 605-619.

Lingrey, S. H., 1982, Structural geology and tectonic evolution of the northeastern Rincon Mountains, Cochise and Pima Counties, Arizona [Ph.D. thesis]: Tucson, University of Arizona, $202 \mathrm{p}$.

Lipman, P. W., 1980, Cenozoic volcanism in the western United States; Implications for continental tectonics, in Burchfiel, B. C., Oliver, J. E., and Silver, L. T., eds., Continental tectonics: Washington, D.C., National Academy of Sciences, p. 161-174.

— , 1981, Volcano-tectonic setting of Tertiary ore deposits, southern Rocky Mountains, in Dickinson, W. R., and Payne, W. D., eds., Relations of tectonics to ore deposits in the southern Cordillera: Arizona Geological Society Digest, v. 14, p. 199-226.

, 1989, Field guide to the Tucson Mountains caldera, in Chapin, C. E., and Zidek, J., eds., Field excursions to volcanic terranes in the western United States; Volume 1, Southern Rocky Mountain region: New Mexico Bureau of Mines and Mineral Resources Memoir 46, p. 133-138.

Lipman, P. W., and Fridrich, C. J., 1990, Cretaceous caldera systems; Tucson and Sierrita Mountains, in Gehrels, G. E., and Spencer, J. E., eds., Geologic excursions through the Sonoran Desert region, Arizona and Sonora: Arizona Geological Survey Special Paper 7, p. 51-65.

Lipman, P. W., and Mehnert, H. H., 1975, Late Cenozoic basaltic volcanism and development of the Rio Grande depression in the southern Rocky Mountains, in Curtis, B. F., 1975, Cenozoic history of the southern Rocky Mountains: Geological Society of America Memoir 144, p. 119-154.

Lipman, P. W., and Sawyer, D. A., 1985, Mesozoic ash-flow caldera fragments in 
southeastern Arizona and their relation to porphyry copper deposits: Geology, v. 13, p. 652-656.

Lipman, P. W., Steven, T. A., and Mehnert, H. H., 1970, Volcanic history of the San Juan Mountains, Colorado, as indicated by potassium-argon dating: Geological Society of America Bulletin, v. 81, p. 2329-2352.

Lipman, P. W., Prostka, H. J., and Christiansen, R. L., 1971, Evolving subduction zones in the western United States, as interpreted from igneous rocks: Science, v. 174, p. 821-825.

_ 1972 , Cenozoic volcanism and plate-tectonic evolution of the western United States; 1, Early and middle Cenozoic: Philosophical Transactions of the Royal Society of London, v. A271, p. 217-248.

Lipman, P. W., Mehnert, H. H., and Naeser, C. W., 1986, Evolution of the Latir volcanic field, northern New Mexico, and its relation to the Rio Grande rift, as indicated by potassium-argon and fission-track dating: Journal of Geophysical Research, v. 91, p. 6329-6345.

Lister, G. S., and Davis, G. A., 1989, The origin of metamorphic core complexes and detachment faults formed during Tertiary continental extension in the northern Colorado River region, U.S.A.: Journal of Structural Geology, v. 11, p. $65-94$.

Lister, G. S., and Snoke, A. W., 1984, S-C mylonites: Journal of Structural Geology, v. 6, p. 617-638.

Lister, G. S., Etheridge, M. A., and Symonds, P. A., 1986, Detachment faulting and the evolution of passive continental margins: Geology, v. 14, p. 246-250.

Livaccari, R. F., 1979, Late Cenozoic tectonic evolution of the western United States: Geology, v. 7, p. 72-75.

Livingston, D. E., Mauger, R. L., and Damon, P. E., 1968, Geochronology of the emplacement, enrichment, and preservation of Arizona porphyry copper deposits: Economic Geology, v. 63, p. 30-36.

Longwell, C. R., 1951, Megabreccia developed downslope from large faults: American Journal of Science, v. 249, p. 343-355.

Lorenz, J. C., 1988, Triassic-Jurassic rift-basin sedimentology: New York, Van Nostrand Reinhold, $315 \mathrm{p}$.

Lowell, J. D., 1968, Geology of the Kalamazoo orebody, San Manuel district, Arizona: Economic Geology, v. 63, p. 645-654.

Lowell, J. D., and Guilbert, J. M., 1970, Lateral and vertical alterationmineralization zoning in porphyry copper deposits: Economic Geology, v. 65, p. $373-408$.

Lucas, S. G., and Ingersoll, R. V., 1981, Cenozoic continental deposits of New Mexico; An overview: Geological Society of America Bulletin, v. 92, p. 917-932.

Lucchitta, I., 1990, Role of heat and detachment in continental extension as viewed from the eastern Basin and Range province in Arizona: Tectonophysics, v. 174, p. 77-114.

Lucchitta, I., Suneson, N., and Shackelford, T. J., 1981, Comment and reply on 'Tertiary tectonic denudation of a Mesozoic-early Tertiary(?) gneiss complex, Rawhide Mountains, western Arizona': Geology, v. 9, p. 50-52.

Lustig, L. K., 1969, Trend-surface analysis of the Basin and Range province, and some geomorphic implications: U.S. Geological Survey Professional Paper $500-\mathrm{D}, 70 \mathrm{p}$.

Mack, G. H., and Rasmussen, K. A., 1984, Alluvial-fan sedimentation of the Cutler Formation (Permo-Carboniferous) near Gateway, Colorado: Geological Society of America Bulletin, v. 95, p. 109-116.

Mack, G. H., and Seager, W. R., 1990, Tectonic control on facies distribution of the Camp Rice and Palomas Formations (Pliocene-Pleistocene) in the southern Rio Grande rift: Geological Society of America Bulletin, v. 102, p. $45-53$.

Malavieille, J., 1987, Extensional shearing deformation and kilometer-scale "a" type folds in a Cordilleran metamorphic core complex (Raft River Mountains, northwestern Utah): Tectonics, v. 6, p. 423-448.

Marvin, R. F., Naeser, C. W., and Mehnert, H. H., 1978, Tabulation of radiometric ages, including unpublished $\mathrm{K}-\mathrm{Ar}$ and fission-track ages for rocks in southeastern Arizona and southwestern New Mexico, in Callender, J. F., Wilt, J. C., and Clemons, R. E., eds., Land of Cochise, southeastern Arizona: New Mexico Geological Society 29th Annual Field Conference Guidebook, p. $243-252$.

Marvin, R. F., Zen, E-A., and Mehnert, H. H., 1982, Tertiary volcanics along the eastern flank of the Pioneer Mountains, southwest Montana: Isochron/West, no. 33 , p. 11-13.

Marvin, R. F., Mehnert, H. H., and Zartman, R. E., 1988, U.S. Geological Survey radiometric ages; Compilation "C", Part two; Arizona and New Mexico: Isochron/West, no. 51, p. 5-13.

Mathis, R. S., 1982, Mid-Tertiary detachment faulting in the southeastern Newberry mountains, Clark County, Nevada, in Frost, E. G., and Martin, D. L., eds., Mesozoic-Cenozoic tectonic evolution of the Colorado River region, California, Arizona, and Nevada: San Diego, California, Cordilleran Publishers, p. 327-340.

McClelland, W. C., 1982, Structural geology of the central Sacramento Mountains, San Bernardino County, California, in Frost, E. G., and Martin, D. L., eds., Mesozoic-Cenozoic tectonic evolution of the Colorado River region, California, Arizona, and Nevada: San Diego, California, Cordilleran Publishers, p. 401-406.

McDowell, F. W., 1971, K-Ar ages of igneous rocks from the western United States: Isochron/West, no. 2, p. 1-16.

- 1978, Potassium-argon dating in the Trans-Pecos Texas volcanic field, in Walton, A. W., and Henry, C. D., eds., Cenozoic geology of the Trans-Pecos volcanic field of Texas: Texas Bureau of Economic Geology Guidebook 19, p. 10-18.

McDowell, F. W., and Clabaugh, S. E., 1979, Ignimbrites of the Sierra Madre Occidental and their relation to the tectonic history of western Mexico, in Chapin, C. E., and Elston, W. E., eds., Ash-flow tuffs: Geological Society of America Special Paper 180, p. 113-124.

McDowell, F. W., and Keizer, R. P., 1977, Timing of mid-Tertiary volcanism in the Sierra Madre Occidental between Durango City and Mazatlan, Mexico: Geological Society of America Bulletin, v. 88, p. 1479-1487.

McFadden, L. D., 1981, Quaternary evolution of the Canada del Oro valley, southeastern Arizona: Arizona Geological Society Digest, v. 13, p. 13-19.

McIntosh, W. C., 1989, Timing and distribution of ignimbrite volcanism in the Eocene-Miocene Mogollon-Datil volcanic field, in Chapin, C. E., and Zidek, J., eds., Field excursions to volcanic terranes in the western United States; Volume 1, Southern Rocky Mountain region: New Mexico Bureau of Mines and Mineral Resources Memoir 46, p. 58-59.

McIntyre, D. H., Ekren, E. B., and Hardyman, R. F., 1982, Stratigraphic and structural framework of the Challis Volcanics in the eastern half of the Challis quadrangle, Idaho, in Bonnichsen, B., and Breckenridge, R. M., eds., Cenozoic geology of Idaho: Idaho Bureau of Mines and Geology Bulletin 26, p. 3-22.

McKee, E. H., 1971, Tertiary igneous chronology of the Great Basin of western United States; Implications for tectonic models: Geological Society of America Bulletin, v. 82, p. 3497-3502.

McKee, E. H., Noble, D. C., and Silberman, M. L., 1970, Middle Miocene hiatus in volcanic activity in the Great Basin area of the western United States: Earth and Planetary Science Letters, v. 8, p. 93-96.

Melosh, H. J., 1983, Acoustic fluidization: American Scientist, v. 71, p. 158-165.

- 1990, Mechanical basis for low-angle normal faulting in the Basin and Range province: Nature, v. 343, p. 331-335.

Melton, M. A., 1965, The geomorphic and paleoclimatic significance of alluvial deposits in southern Arizona: Journal of Geology, v. 73, p. 1-38.

Menges, C. M., and McFadden, L. D., 1981, Evidence for a latest Miocene to Pliocene transition from basin-range tectonics to post-tectonic landscape evolution in southeastern Arizona: Arizona Geological Society Digest, v. 13, p. $151-160$.

Miall, A. D., 1977, A review of the braided river depositional environment: Earth Science Reviews, v. 13, p. 1-62.

, 1978, Lithofacies types and vertical profile models in braided-river deposits; A summary, in Miall, A. D., ed., Fluvial sedimentology: Canadian Society of Petroleum Geologists Memoir 5, p. 597-604.

Miller, E. L., and Gans, P. B., 1989, Cretaceous crustal structure and metamorphism in the hinterland of the Sevier thrust belt, western U.S. Cordillera: 
Geology, v. 17, p. 59-62.

Miller, E. L., Gans, P. B., and Garing, J., 1983, The Snake Range decollement; An exhumed mid-Tertiary ductile-brittle transition: Tectonics, v. 2, p. 239-263.

Miller, J.M.G., and John, B. E., 1988, Detached strata in a Tertiary low-angle normal fault terrane, southeastern California; A sedimentary record of unroofing, breaching, and continued slip: Geology, v. 16, p. 645-648.

Molenaar, C. M., 1983, Major depositional cycles and regional correlations of Upper Cretaceous rocks, southern Colorado Plateau and adjacent areas, in Reynolds, M. W., and Dolly, E. D., eds., Mesozoic paleogeography of the west-central United States: Rocky Mountain Section, Society of Economic Paleontologists and Mineralogists Rocky Mountain Paleogeography Symposium 2, p. 201-224.

Montgomery, E. L., 1963, The geology and ground water investigation of the Tres Alamos dam site area of the San Pedro River, Cochise County, Arizona [M.S. thesis]: Tucson, University of Arizona, $61 \mathrm{p}$.

Moores, E. M., 1968, Mio-Pliocene sediments, gravity slides, and their tectonic significance, east-central Nevada: Journal of Geology, v. 76, p. 88-98.

Moores, E. M., Scott, R. B., and Lumsden, W. W., 1968, Tertiary tectonics of the White Pine-Grant Range region, east-central Nevada, and some regional implications: Geological Society of America Bulletin, v. 79, p. 1703-1726.

Morgan, P., Seager, W. R., and Golombek, M. P., 1986, Cenozoic thermal, mechanical, and tectonic evolution of the Rio Grande rift: Journal of Geophysical Research, v. 91, p. 6263-6276.

Morrison, R. B., 1985, Pliocene/Quaternary geology, geomorphology, and tectonics of Arizona, in Weide, D. L., ed., Soils and Quaternary geology of the southwestern United States: Geological Society of America Special Paper 203, p. 123-146.

Morton, W. H., and Black, R., 1975, Crustal attenuation in Afar, in Pilger, A., and Rolser, A., eds., Afar Depression of Ethiopia, Volume 1: Stuttgart, Schweizerbartsche Verlagsbuchhandlung, Inter-Union Commission on Geodynamics Report 14, p. 55-65.

Murray, K. S., 1982, K-Ar age bracket on the initiation of Basin and Range faulting in southeastern California: Isochron/West, no. 33, p. 3-7.

Nadon, G. C., and Middleton, G. V., 1985, The stratigraphy and sedimentology of the Fundy Group (Triassic) of the St. Martins area, New Brunswick: Canadian Journal of Earth Sciences, v. 22, p. 1183-1203.

Naruk, S. J., 1986, Strain and displacement across the Pinaleno Mountains shear zone, Arizona, U.S.A.: Journal of Structural Geology, v. 8, p. 35-46.

— 1987a, Displacement calculations across a metamorphic core complex mylonite zone; Pinaleno Mountains, southeastern Arizona: Geology, v. 15, p. 656-660.

__ , 1987b, Kinematic significance of mylonitic foliation [Ph.D. thesis]: Tucson, University of Arizona, $72 \mathrm{p}$.

Naruk, S. J., and Bykerk-Kauffman, A., 1990, Late Cretaceous and Tertiary deformation of the Santa Catalina metamorphic core complex, Arizona, in Gehrels, G. E., and Spencer, J. E., eds., Geologic excursions through the Sonoran Desert region, Arizona and Sonora: Arizona Geological Survey Special Paper 7, p. 41-50.

Naruk, S. J., and 5 others, 1986, Kink folding in an extended terrane, Tortilla Mountains, southeastern Arizona: Geology, v. 14, p. 1012-1015.

Nations, J. D., Landye, J. J., and Hevly, R. H., 1982, Location and chronology of Tertiary sedimentary deposits in Arizona; A review, in Ingersoll, R. V., and Woodburne, M. O., eds., Cenozoic nonmarine deposits of California and Arizona: Pacific Section, Society of Economic Paleontologists and Mineralogists, p. 107-122.

Nations, J. D., Wilt, J. C., and Hevly, R. H., 1985, Cenozoic paleogeography of Arizona, in Flores, R. M., and Kaplan, S. S., eds., Cenozoic paleogeography of the west-central United States: Rocky Mountain Section, Society of Economic Paleontologists and Mineralogists Rocky Mountain Paleogeography Symposium 3, p. 335-355.

Nielson, J. E., and Beratan, K. K., 1990, Tertiary basin development and tectonic implications, Whipple detachment system, Colorado River extensional corridor, California and Arizona: Journal of Geophysical Research, v. 95, p. $599-614$.
Nielson, J. E., Lux, D. R., Dalrymple, G. B., and Glazner, A. F., 1990, Age of the Peach Springs Tuff, southeastern California and western Arizona: Journal of Geophysical Research, v. 95, p. 571-580.

Nilsen, T. H., 1982, Alluvial fan deposits, in Scholle, P. A., and Spearing, D., eds, Sandstone depositional environments: American Association of Petroleum Geologists Memoir 31, p. 49-86.

Noble, D. C., 1972, Some observations on the Cenozoic volcano-tectonic evolution of the Great Basin, western United States: Earth and Planetary Science Letters, v. 17, p. 142-150.

Noblett, J. B., 1981, Subduction-related origin of the volcanic rocks of the Eocene Clarno Formation near Cherry Creek, Oregon: Oregon Geology, v. 43, p. 91-99.

Nourse, J. A., 1990, Tectonostratigraphic development and strain history of the Magdalena core complex, northern Sonora, Mexico, in Gehrels, G. E., and Spencer, J. E., eds., Geologic excursions through the Sonoran Desert region, Arizona and Sonora: Arizona Geological Survey Special Paper 7, p. $155-164$.

Olivares, M. D., 1991, Sedimentary facies in the Upper Oligocene Mineta Formation, Pima and Cochise Counties, Arizona [M.S. thesis]: Tucson, University of Arizona in preparation.

Otton, J. K., 1982, Tertiary extensional tectonics and associated volcanism in west-central Arizona, in Frost, E. G., and Martin, D. L., eds., MesozoicCenozoic extensional tectonic evolution of the Colorado River region, California, Arizona, and Nevada: San Diego, Cordilleran Publishers, p. 143-157.

Palais, D. G., and Peacock, S. M., 1987, P-T indicators in metamorphic rocks from the Santa Catalina metamorphic core complex, SE Arizona; Contact metamorphism at shallow crustal levels: Geological Society of America Abstracts with Programs, v. 19, p. 438.

-, 1990 , Metamorphic and stratigraphic constraints on the evolution of the Santa Catalina Mountains metamorphic core complex, Arizona: Journal of Geophysical Research, v. 95, p. 501-507.

Palmer, A. R., 1983, The Decade of North American Geology 1983 time scale: Geology, v. 11, p. 746-754.

Parrish, R. R., Carr, S. D., and Parkinson, D. L., 1988, Eocene extensional tectonics and geochronology of the southern Omineca Belt, British Columbia and Washington: Tectonics, v. 7, p. 181-212.

Pashley, E. F., Jr., 1966, Structure and stratigraphy of the central, northern, and eastern parts of the Tucson basin, Arizona [Ph.D. thesis]: Tucson, University of Arizona, $273 \mathrm{p}$.

Pearson, R. C., and Obradovich, J. D., 1977, Eocene rocks in northeast Washington; Radiometric ages and correlation: U.S. Geological Survey Bulletin $1433,41 \mathrm{p}$.

Peirce, H. W., 1976, Elements of Paleozoic tectonics in Arizona: Arizona Geological Society Digest, v. 10, p. 37-57.

Peterson, N. P., 1938, Geology and ore deposits of the Mammoth mining camp area, Pinal County, Arizona: Arizona Bureau of Mines Bulletin 144, 63 p.

Petit, J-P., and Beauchamp, J., 1986, Synsedimentary faulting and palaeocurrent patterns in the Triassic sandstones of the High Atlas (Morocco): Sedimentology, v. 33, p. 817-829.

Potochnik, A. R., 1989, Depositional style and tectonic implications of the Mogollon Rim Formation (Eocene), east-central Arizona, in Anderson, O. J., Lucas, S. R., Love, D. W., and Cather, S. M., eds., Southeastern Colorado Plateau: New Mexico Geological Society 40th Annual Field Conference Guidebook, p. 107-118.

Proffett, J. M., Jr., 1977, Cenozoic geology of the Yerington district, Nevada, and implications for the nature of Basin and Range faulting: Geological Society of America Bulletin, v. 88, p. 247-266.

- 1984, Late Cenozoic normal faulting, tilting, and extension in the Yerington district, Nevada, in Lintz, J., Jr., ed., Western geological excursions, Volume 4: Reno, University of Nevada Mackay School of Mines, p. 161-176.

Pye, W. D., 1959, Catalog of principal sedimentary formation names in southern Arizona and northern Sonora: Arizona Geological Society Digest, v. 2, p. 274281. 
Ramsey, J. G., 1980, Shear zone geometry; A review: Journal of Structural Geology, v. 2, p. 83-99.

Ransome, F. L., 1903, Geology of the Globe copper district, Arizona: U.S. Geological Survey Professional Paper 12, 168 p.

- 1919, The copper deposits of Ray and Miami, Arizona: U.S. Geological Survey Professional Paper 115, $179 \mathrm{p}$.

_ , 1923, Ray folio, Arizona: U.S. Geological Survey Geologic Atlas of the United States Folio 217, $24 \mathrm{p}$.

Ransome, F. L., Emmons, W. H., and Garrey, G. H., 1910, Geology and ore deposits of the Bullfrog district, Nevada: U.S. Geological Survey Bulletin $407,130 \mathrm{p}$

Ratte, J. C., Marvin, R. F., Naeser, C. W., and Bikerman, M., 1984, Calderas and ash-flow tuffs of the Mogollon Mountains, southwestern New Mexico: Journal of Geophysical Research, v. 89, p. 8713-8732.

Rehrig, W. A., 1986, Processes of regional Tertiary extension in the western Cordillera; Insights from metamorphic core complexes, in Mayer, L., ed., Extensional tectonics of the southwestern United States; A perspective on processes and kinematics: Geological Society of America Special Paper 208, p. 97-122.

Rehrig, W. A., and Heidrick, T. L., 1976, Regional tectonic stress during the Laramide and late Tertiary intrusive periods, Basin and Range province, Arizona: Arizona Geological Society Digest, v. 10, p. 205-228.

Rehrig, W. A., and Reynolds, S. J., 1980, Geologic and geochronologic reconnaissance of a northwest-trending zone of metamorphic core complexes in southern and western Arizona, in Crittenden, M. D., Jr., Coney, P. J., and Davis, G. H., eds., Cordilleran metamorphic core complexes: Geological Society of America Memoir 153, p. 131-157.

Rehrig, W. A., Shafiqullah, M., and Damon, P. E., 1980, Geochronology, geology, and listric normal faulting of the Vulture Mountains, Maricopa County, Arizona, in Jenney, J. P., and Stone, C., eds., Studies in western Arizona: Arizona Geological Society Digest, v. 12, p. 89-110.

Reiche, P., 1938, An analysis of cross-lamination of the Coconino Sandstone: Journal of Geology, v. 44, p. 905-932.

Reynolds, S. J., 1980, Geologic framework of west-central Arizona, in Jenney, J. P., and Stone, C., eds., Studies in western Arizona: Arizona Geological Society Digest, v. 12, p. 1-16.

— 1985 , Geology of the South Mountains, central Arizona: Arizona Bureau of Geology and Mineral Technology Bulletin 195, $61 \mathrm{p}$.

Reynolds, S. J., and Keith, S. B., 1982, Geochemistry and mineral potential of peraluminous granitoids: Arizona Bureau of Geology and Mineral Technology Fieldnotes, v. 12, no. 4, p. 4-6.

Reynolds, S. J., and Lister, G. S., 1987, Kinematics of mylonitic rocks in metamorphic core complexes of Arizona; Origin of the mylonitic front: Geological Society of America Abstracts with Programs, v. 19, p. 443.

_- 1990 , Folding of mylonitic zones in Cordilleran metamorphic core complexes; Evidence from near the mylonitic front: Geology, v. 18, p. 216-219.

Reynolds, S. J., and Rehrig, W. A., 1980, Mid-Tertiary plutonism and mylonitization, South Mountains, central Arizona, in Crittenden, M. D., Jr., Coney, P. J., and Davis, G. H., eds., Cordilleran metamorphic core complexes: Geological Society of America Memoir 153, p. 159-175.

Reynolds, S. J., and Spencer, J. E., 1985, Evidence for large-scale transport on the Bullard detachment fault, west-central Arizona: Geology, v. 13, p. 353-356.

Reynolds, S. J., and 6 others, 1986a, Compilation of radiometric age determinations in Arizona: Arizona Bureau of Geology and Mineral Technology Bulletin 197, $258 \mathrm{p}$.

Reynolds, S. J., Shafiqullah, M., Damon, P. E., and DeWitt, E., 1986b, Early Miocene mylonitization and detachment faulting, South Mountains, central Arizona: Geology, v. 14, p. 283-286.

Reynolds, S. J., Welty, J. W., and Spencer, J. E., 1986c, Volcanic history of Arizona: Arizona Bureau of Geology and Mineral Technology Fieldnotes, v. 16 , no. 2 , p. $1-5$.

Reynolds, S. J., Richard, S. M., Haxel, G. B., Tosdal, R. M., and Laubach, S. E., 1988, Geologic setting of Mesozoic and Cenozoic metamorphism in Arizona, in Ernst, W. G., ed., Metamorphism and crustal evolution of the western
United States; Rubey Volume 7: Englewood Cliffs, New Jersey, PrenticeHall, p. 466-501.

Risley, R., 1987, Sedimentation and stratigraphy of the Lower Cretaceous Amole Arkose, Tucson Mountains, Arizona, in Dickinson, W. R., and Klute, M. A., eds., Mesozoic rocks of southern Arizona and adjacent areas: Arizona Geological Society Digest, v. 18, p. 215-228.

Robinson, P. T., McKee, E. H., and Moiola, R. J., 1968, Cenozoic volcanism and sedimentation, Silver Peak region, western Nevada and adjacent California, in Coats, R. R., Hay, R. L., and Anderson, C. A., eds., Studies in volcanology: Geological Society of America Memoir 116, p. 577-611.

Roddy, M. S., Reynolds, S. J., Smith, B. M., and Ruiz, J., 1988, K-metasomatism and detachment-related mineralization, Harcuvar Mountains, Arizona: Geological Society of America Bulletin, v. 100, p. 1627-1639.

Rogers, J.J.W., and Novitzky-Evans, J. M., 1977, The Clarno Formation of central Oregon, U.S.A.; Volcanism on a thin continental margin: Earth and Planetary Science Letters, v. 34, p. 56-66.

Ruiz, J., Patchett, P. J., and Arculus, R. J., 1988, Nd-Sr isotope composition of lower crustal xenoliths; Evidence for the origin of mid-Tertiary felsic volcanics in Mexico: Contributions to Mineralogy and Petrology, v. 99, p. 36-43.

Sawlan, M. G., and Smith, J. G., 1984, Petrologic characteristics, age and tectonic setting of Neogene volcanic rocks in northern Baja California Sur, Mexico, in Frizzell, V. A., Jr., ed., Geology of the Baja California peninsula: Pacific Section, Society of Economic Paleontologists and Mineralogists Book 39, p. 237-251.

Scarborough, R. B., 1975, Chemistry and age of late Cenozoic air-fall ashes in southeastern Arizona [M.S. thesis]: Tucson, University of Arizona, 107 p.

— , 1979, Cenozoic history and uranium in southern Arizona: Arizona Bureau of Geology and Mineral Technology Fieldnotes, v. 9, no. 3, p. 1-2, 14-16.

- , 1989, Cenozoic erosion and sedimentation in Arizona, in Jenney, J. P., and Reynolds, S. J., eds., Geologic evolution of Arizona: Arizona Geological Society Digest 17 , p. 515-537.

Scarborough, R. B., and Peirce, H. W., 1978, Late Cenozoic basins of Arizona, in Callender, J. F., Wilt, J. C., and Clemons, R. E., eds., Land of Cochise, southeastern Arizona: New Mexico Geological Society 29th Annual Field Conference Guidebook, p. 253-259.

Scarborough, R. B., and Wilt, J. C., 1979, A study of uranium favorability of Cenozoic sedimentary rocks, Basin and Range province, Arizona: U.S. Geological Survey Open-File Report 79-1429, $101 \mathrm{p}$.

Schmidt, E. A., 1971, A structural investigation of the northern Tortilla Mountains, Pinal County, Arizona [Ph.D. thesis]: Tucson, University of Arizona, $248 \mathrm{p}$.

Seager, W. R., 1981, Geology of Organ Mountains and southern San Andres Mountains, New Mexico: New Mexico Bureau of Mines and Mineral Resources Memoir 36, $97 \mathrm{p}$.

Seager, W. R., and Mack, G. H., 1986, Laramide paleotectonics of southern New Mexico, in Peterson, J. A., ed., Paleotectonics and sedimentation in the Rocky Mountain region, United States: American Association of Petroleum Geologists Memoir 41, p. 669-685.

Seager, W. R., and Morgan, P., 1979, Rio Grande rift in southern New Mexico, west Texas, and northern Chihhuahua, in Riecker, R. E., ed., Rio Grande rift; Tectonics and magmatism: Washington, D.C., American Geophysical Union, p. 87-106.

Seager, W. R., Shafiqullah, M., Hawley, J. W., and Marvin, R. F., 1984, New K-Ar dates from basalts and the evolution of the southern Rio Grande rift: Geological Society of America Bulletin, v. 95, p. 87-99.

Self, S., Goff, F., Gardner, J. N., Wright, J. V., and Kite, W. N., 1986, Explosive rhyolitic volcanism in the Jemez Mountains; Vent locations, caldera development, and relation to regional structure: Journal of Geophysical Research, v. 91 , p. $1779-1798$.

Sengor, A.M.C., 1987, Tectonic subdivisions and evolution of Asia: Technical University of Istanbul Bulletin, v. 40, p. 355-435.

Sengor, A.M.C., 1990, Plate tectonics and orogenic research after 25 years; A Tethyan perspective: Earth-Science Reviews, v. 27, p. 1-201. 
Severinghaus, J., and Atwater, T., 1990, Cenozoic geometry and thermal state of the subducting slabs beneath western North America, in Wernicke, B. P., ed., Basin and Range extensional tectonics near the latitude of Las Vegas, Nevada: Geological Society of America Memoir 176, p. 1-22.

Shackelford, T. J., 1980, Tertiary tectonic denudation of a Mesozoic-early Tertiary(?) gneiss complex, Rawhide Mountains, western Arizona: Geology, v. 8, p. $190-194$.

— , 1989, Structural geology of the Rawhide Mountains, Mohave County, Arizona, in Spencer, J. E., and Reynolds, S. J., eds., Geology and mineral resources of the Buckskin and Rawhide Mountains, west-central Arizona: Arizona Geological Survey Bulletin 198, p. 15-46.

Shafiqullah, M., Lynch, D. J., and Damon, P. E., 1976, Geology, geochronology, and geochemistry of the Picacho Peak area, Pinal County, Arizona: Arizona Geological Society Digest, v. 10, p. 305-324.

Shafiqullah, M., Damon, P. E., Lynch, D. J., and Kuck, P. H., 1978, Mid-Tertiary magmatism in southeastern Arizona, in Callender, J. F., Wilt, J. C., and Clemons, R. E., eds., Land of Cochise, southeastern Arizona: New Mexico Geological Society 29th Annual Field Conference Guidebook, p. 231-241.

Shafiqullah, M., and 5 others, 1980, K-Ar geochronology and geologic history of southwestern Arizona and adjacent areas, in Jenney, J. P., and Stone, C., eds., Studies in western Arizona: Arizona Geological Society Digest, v. 12, p. 201-260.

Shafiqullah, M., Peirce, H. W., and Damon, P. E., 1988, Illite K-Ar dating and the Catalina detachment fault: Geological Society of America Abstracts with Programs, v. 20, p. A230-A231.

Shakel, D. W., 1978, Santa Catalina Mountains via Catalina Highway, in Callender, J. F., Wilt, J. C., and Clemons, R. E., eds., Land of Cochise, southeastern Arizona: New Mexico Geological Society 29th Annual Field Conference Guidebook, p. 105-111.

Shenk, J. D., 1990, Economic geology of the White Cliffs diatomite deposit, Mammoth, Arizona [M.S. thesis]: Tucson, University of Arizona, $157 \mathrm{p}$.

Sheridan, M. F., 1978, The Superstition cauldron complex, in Burt, D. M., and Péwé, T. L., eds., Guidebook to the geology of central Arizona: Arizona Bureau of Geology and Mineral Technology Special Paper 2, p. 85-96.

Sherrod, D. R., Pickthorn, L. G., Tosdal, R. M., Grubensky, M. J., and Koch, R. D., 1987, Major early Miocene extensional deformation in southwestern Arizona and southeastern California: Geological Society of America Abstracts with Programs, v. 19, p. 841.

Shreve, R. L., 1968, The Blackhawk landslide: Geological Society of America Special Paper 108, $97 \mathrm{p}$.

Shride, A. F., 1967, Younger Precambrian geology in southern Arizona: U.S. Geological Survey Professional Paper 566, $89 \mathrm{p}$.

Silver, L. T., 1978, Precambrian formations and Precambrian history in Cochise County, southeastern Arizona, in Callender, J. F., Wilt, J. C., and Clemons, R. E., eds., Land of Cochise, southeastern Arizona: New Mexico Geological Society 29th Annual Field Conference Guidebook, p. 157-163.

Simons, F. S., 1964, Geology of the Klondyke Quadrangle, Graham and Pinal Counties, Arizona: U.S. Geological Survey Professional Paper 461, 173 p.

— , 1987, Geologic map of the Black Rock Wilderness Study Area, Graham County, Arizona: U.S. Geological Survey Miscellaneous Field Studies Map MF-1918, scale 1:24,000.

Simpson, C., and Schmid, S. M., 1983, An evaluation of criteria to deduce the sense of movement in sheared rocks: Geological Society of America Bulletin, v. 94, p. $1281-1288$.

Sinno, Y. A., Keller, G. R., and Sbar, M. L., 1981, A crustal seismic refraction study in west-central Arizona: Journal of Geophysical Research, v. 86, p. 5023-5038.

Smedes, H. W., and Prostka, H. J., 1972, Stratigraphic framework of the Absaroka Volcanic Supergroup in the Yellowstone National Park region: U.S. Geological Survey Professional Paper 729-C, p. C1-C33.

Smith, C. H., and Gehrels, G. E., 1987, Evidence for Late Cretaceous-early Tertiary thrust faulting, peraluminous plutonism, and metamorphism in the Little Rincon Mountains, southeastern Arizona: Geological Society of America Abstracts with Programs, v. 19, p. 452.
Smith, R. B., and Bruhn, R. L., 1984, Intraplate extensional tectonics of the eastern Basin-Range; Inferences on structural style from seismic reflection data, regional tectonics, and thermal-mechanical models of brittle-ductile deformation: Journal of Geophysical Research, v. 89, p. 5733-5762.

Smith, W. J., 1967, Cenozoic stratigraphy near Redington, Pima County, Arizona [M.S. thesis]: Tucson, University of Arizona, $96 \mathrm{p}$.

Snoke, A. W., and Miller, D. M., 1988, Metamorphic and tectonic history of the northeastern Great Basin, in Ernst, W. G., ed., Metamorphism and crustal evolution of the western United States, Rubey Volume 7: Englewood Cliffs, New Jersey, Prentice-Hall, p. 606-648.

Snyder, W. S., Dickinson, W. R., and Silberman, M. L., 1976, Tectonic implications of space-time patterns of Cenozoic magmatism in the western United States: Earth and Planetary Science Letters, v. 32, p. 91-106.

Sonder, L. J., England, P. C., Wernicke, B. P., and Christiansen, R. L., 1987, A physical model for Cenozoic extension of western North America, in Coward, M. P., Dewey, J. F., and Hancock, P. L., eds., Continental extensional tectonics: Geological Society of London Special Publication 28, p. 187-201.

Spencer, J. E., 1984, Role of tectonic denudation in warping and uplift of low-angle normal faults: Geology, v. 12, p. 95-98.

- , 1985, Miocene low-angle normal faulting and dike emplacement, Homer Mountain and surrounding areas, southeastern California and southernmost Nevada: Geological Society of America Bulletin, v. 96, p. 1140-1155.

Spencer, J. E., and Chase, C. G., 1989, Role of crustal flexure in initiation of low-angle normal faults and implications for structural evolution of the Basin and Range province: Journal of Geophysical Research, v. 94, p. 1765-1775.

Spencer, J. E., and Reynolds, S. J., 1986, Some aspects of the middle Tertiary tectonics of Arizona and southeastern California, in Beatty, B., and Wilkinson, P.A.K., eds., Frontiers in geology and ore deposits of Arizona and the Southwest: Arizona Geological Society Digest, v. 16, p. 102-107.

, 1989a, Introduction to the geology and mineral resources of the Buckskin and Rawhide Mountains, in Spencer, J. E., and Reynolds, S. J., eds., Geology and mineral resources of the Buckskin and Rawhide Mountains, westcentral Arizona: Arizona Geological Survey Bulletin 198, p. 1-10.

, 1989b, Tertiary structure, stratigraphy, and tectonics of the Buckskin Mountains, in Spencer, J. E., and Reynolds, S. J., eds., Geology and mineral resources of the Buckskin and Rawhide Mountains, west-central Arizona: Arizona Geological Survey Bulletin 198, p. 103-167.

_ $1989 \mathrm{c}$, Middle Tertiary tectonics of Arizona and the Southwest, in Jenney, J. P., and Reynolds, S. J., eds., Geological evolution of Arizona: Arizona Geological Society Digest 17, p. 539-574.

_, 1990 , Relationship between Mesozoic and Cenozoic tectonic features in west-central Arizona and adjacent southeastern California: Journal of Geophysical Research, v. 95, p. 539-555.

___ 1991, Tectonics of Tertiary extension along a transect through west-central Arizona: Geological Society of America, v. 103, in press.

Spencer, J. E., and Welty, J. W., 1986, Possible controls of base- and preciousmetal mineralization associated with Tertiary detachment faults in the lower Colorado River trough, Arizona and California: Geology, v. 14, p. 195-198.

_ , 1989, Geology of mineral deposits in the Buckskin and Rawhide Mountains, west-central Arizona, in Spencer, J. E., and Reynolds, S. J., eds., Geology and mineral resources of the Buckskin and Rawhide Mountains, west-central Arizona: Arizona Geological Survey Bulletin 198, p. 223-254.

Spencer, J. E., and 5 others, 1989a, Geology and mineral deposits of the central Artillery Mountains, in Spencer, J. E., and Reynolds, S. J., eds., Geology and mineral resources of the Buckskin and Rawhide Mountains, west-central Arizona: Arizona Geological Survey Bulletin 198, p. 168-183.

Spencer, J. E., Shafiqullah, M., Miller, R. J., and Pickthorn, L. G., 1989b, K-Ar geochronology of Miocene extension, volcanism, and potassium metasomatism in the Buckskin and Rawhide Mountains, in Spencer, J. E., and Reynolds, S. J., eds., Geology and mineral resources of the Buckskin and Rawhide Mountains, west-central Arizona: Arizona Geological Survey Bulletin 198, p. 184-189.

Spieker, E. M., 1946, Late Mesozoic and early Cenozoic history of central Utah: 
U.S. Geological Survey Professional Paper 205-D, p. 117-161.

Stanley, R. G., 1987, New estimates of displacement along the San Andreas fault in central California based on paleobathymetry and paleogeography: Geology, v. 15, p. 171-174.

Steel, R. J., and Aasheim, S. M., 1978, Alluvial sand deposition in a rapidly subsiding basin (Devonian, Norway), in Miall, A. D., ed., Fluvial sedimentology: Canadian Society of Petroleum Geologists Memoir 5, p. 385-412.

Stein, R. S., and Barrientos, S. E., 1985, Planar high-angle faulting in the Basin and Range; Geodetic analysis of the 1983 Borah Peak, Idaho, earthquake: Journal of Geophysical Research, v. 90, p. 11355-11366.

Steven, T. A., Rowley, P. D., and Cunningham, C. G., 1984, Calderas of the Marysvale volcanic field, west-central Utah: Journal of Geophysical Research, v. 89, p. 8751-8764.

Stevens, J. B., and Stevens, M. S., 1985, Basin and Range deformation and deformational timing, Trans-Pecos Texas, in Dickerson, P. W., and Muehlberger, W. R., eds., Structure and tectonics of Trans-Pecos Texas: West Texas Geological Society Publication 85-81, p. 157-163.

Stewart, J. H., 1978, Basin-range structure in western North America: A review, in Smith, R. B., and Eaton, G. P., eds., Cenozoic tectonics and regional geophysics of the western Cordillera: Geological Society of America Memoir 152 , p. 1-32.

— 1980, Regional tilt patterns of late Cenozoic basin-range fault blocks, western United States: Geological Society of America Bulletin, v. 91, p. $460-464$.

___ 1983, Extensional tectonics in the Death Valley area, California; Transport of the Panamint Range structural block $80 \mathrm{~km}$ northwestward: Geology, v. 11 , p. $153-157$.

__ , 1988, Tectonics of the Walker Lane belt, western Great Basin; Mesozoic and Cenozoic deformation in a zone of shear, in Ernst, W. G., ed., Metamorphism and crustal evolution of the western United States; Rubey Volume 7: Englewood Cliffs, New Jersey, Prentice-Hall, p. 683-713.

Stewart, J. H., Albers, J. P., and Poole, F. G., 1968, Summary of regional evidence for right-lateral displacement in the western Great Basin: Geological Society of America Bulletin, v. 79, p. 1407-1414.

Stewart, J. H., Moore, W. J., and Zietz, I., 1977, East-west patterns of Cenozoic igneous rocks, aeromagnetic anomalies, and mineral deposits, Nevada and Utah: Geological Society of America Bulletin, v. 88, p. 67-77.

Stock, J., and Molnar, P., 1988, Uncertainties and implications of the Late Cretaceous and Tertiary positions of North America relative to the Farallon, Kula, and Pacific plates: Tectonics, v. 7, p. 1339-1384.

Stock, J. M., and Hodges, K. V., 1989, Pre-Pliocene extension around the Gulf of California and the transfer of Baja California to the Pacific plate: Tectonics, v. 8, p. 99-115.

Streckeisen, A., 1976, To each plutonic rock its proper name: Earth Science Reviews, v. 12, p. 1-33.

Stuckless, J. S., and Sheridan, M. F., 1971, Tertiary volcanic stratigraphy in the Goldfield and Superstition Mountains, Arizona: Geological Society of America Bulletin, v. 82, p. 3235-3240.

Suneson, N., and Lucchitta, I., 1979, K/Ar ages of Cenozoic volcanic rocks, west-central Arizona: Isochron/West, no. 24, p. 25-29.

___ 1983, Origin of bimodal volcanism, southern Basin and Range province, west-central Arizona: Geological Society of America Bulletin, v. 94 p. 1005-1019.

Swift, P. N., 1987, Early Proterozoic turbidite deposition and melange deformation, southeastern Arizona [Ph.D. thesis]: Tucson, University of Arizona, $134 \mathrm{p}$.

Templeman-Kluit, D., and Parkinson, D. L., 1986, Extension across the Eocene Okanagan crustal shear in southern British Columbia: Geology, v. 14, p. 318-321.

Thompson, G. A., and Zoback, M. L., 1979, Regional geophysics of the Colorado Plateau: Tectonophysics, v. 61, p. 149-181.

Thorman, C. H., and Drewes, H. D., 1981, Geology of the Rincon Wilderness Study Area, Pima County, Arizona: U.S. Geological Survey Bulletin 1500 A, p. 5-62.
Titley, S. R., 1981, Geologic and geotectonic setting of porphyry copper deposits in the southern Cordillera, in Dickinson, W. R., and Payne, W. D., eds., Relations of tectonics to ore deposits in the southern Cordillera: Arizona Geological Society Digest, v. 14, p. 79-97.

- 1982 , Geologic setting of porphyry copper deposits, southeastern Arizona, in Titley, S. R., ed., Advances in geology of the porphyry copper deposits, southwestern North America: Tucson, University of Arizona Press, p. 37-58.

Trever, P. F., 1983, Geology of the Gardner Mountain area, Happy Valley Quadrangle, Cochise County, Arizona [M.S. thesis]: Tucson, University of Arizona, $130 \mathrm{p}$.

Tullis, J., and Yund, R. A., 1977, Experimental deformation of dry Westerly granite: Journal of Geophysical Research, v. 82, p. 5705-5718.

Utley, K. W., 1980, Stratigraphy of the Pliocene Quiburis Formation near Mammoth, Arizona [M.S. thesis]: Tempe, Arizona State University, 178 p.

Verosub, K. L., and Moores, E. M., 1981, Tectonic rotations in extensional regimes and their paleomagnetic consequences for oceanic basalts: Journal of Geophysical Research, v. 86, p. 6335-6349.

Voelger, K., 1953, Cenozoic deposits in the southern foothills of the Santa Catalina Mountains near Tucson, Arizona [M.S. thesis]: Tucson, University of Arizona, $101 \mathrm{p}$.

Von Tish, D. B., Allmendinger, R. W., and Sharp, J. W., 1985, History of Cenozoic extension in central Sevier Desert, west-central Utah, from COCORP seismic reflection data: American Association of Petroleum Geologists Bulletin, v. 69, p. 1077-1087.

Walker, J. D., Bartley, J. M., and Glazner, A. F., 1990, Large magnitude Miocene extension in the central Mojave Desert; Implications for Paleozoic to Tertiary paleogeography and tectonics: Journal of Geophysical Research, v. 95, p. 557-569.

Wallace, T. C., Chase, C. G., Holt, W. E., and Hiller, J. W., 1986, A geophysical study of the crustal structure near a metamorphic core complex, in Beatty, B., and Wilkinson, P.A.K., eds., Frontiers in geology and ore deposits of Arizona and the Southwest: Arizona Geological Society Digest, v. 16 p. 153-158.

Walsh, J. L., 1989, The Hell Hole Conglomerate, a study of a mid-Tertiary extensional basin [M.S. thesis]: Tucson, University of Arizona, $57 \mathrm{p}$.

Wark, D. A., Kempter, K. A., and McDowell, F. W., 1990, Evolution of waning, subduction-related magmatism, northern Sierra Madre Occidental, Mexico: Geological Society of America Bulletin, v. 102, p. 1555-1564.

Warner, J. D., 1982, Geology and mineralization of the Blue Rock Mine, northeastern Rincon Mountains, Pima County, Arizona [M.S. thesis]: Tucson, University of Arizona, $131 \mathrm{p}$.

Watkins, N. D., and Baksi, A. K., 1974, Magnetostratigraphy and oroclinal folding of the Columbia River, Steens, and Owyhee basalts in Oregon, Washington, and Idaho: American Journal of Science, v. 274, p. 148-189.

Weibel, W. L., 1981, Depositional history and geology of the Cloudburst Formation near Mammoth, Arizona [M.S. thesis]: Tucson, University of Arizona, $81 \mathrm{p}$.

Wells, R. E., and Heller, P. L., 1988, The relative contribution of accretion, shear, and extension to Cenozoic tectonic rotation in the Pacific Northwest: Geological Society of America Bulletin, v. 100, p. 325-338.

Wells, R. E., Engebretson, D. C., Snavely, P. D., Jr., and Coe, R. S., 1984, Cenozoic plate motions and the volcano-tectonic evolution of western Oregon and Washington: Tectonics, v. 3, p. 275-294.

Wernicke, B. P., 1981, Low-angle normal faults in the Basin and Range province; Nappe tectonics in an extending orogen: Nature, v. 291, p. 645-648.

— 1985 , Uniform-sense simple shear of the continental lithosphere: Canadian Journal of Earth Sciences, v. 22, p. 108-125.

Wernicke, B. P., and Axen, G. J., 1988, On the role of isostasy in the evolution of normal fault systems: Geology, v. 16, p. 848-851.

Wernicke, B. P., and Burchfiel, B. C., 1982, Modes of extensional tectonics: Journal of Structural Geology, v. 4, p. 105-115.

Wernicke, B. P., Burchfiel, B. C., Spencer, J. E., and Guth, P. L., 1982, Magnitude of crustal extension in the southern Great Basin: Geology, v. 10, p. 499-502.

Wernicke, B. P., Guth, P. L., and Axen, G. J., 1984, Tertiary extensional tectonics 
in the Sevier thrust belt of southern Nevada, in Lintz, J., Jr., ed., Western geological excursions, Volume 4: Reno, University of Nevada Mackay School of Mines, p. 473-510.

Wernicke, B. P., Walker, J. D., and Beaufait, M. S., 1985, Structural discordance between Neogene detachments and frontal Sevier thrusts, central Mormon Mountains, southern Nevada: Tectonics, v. 4, p. 213-246.

Wernicke, B. P., Christiansen, R. L., England, P. C., and Sonder, L. J., 1987, Tectonomagmatic evolution of Cenozoic extension in the North American Cordillera, in Coward, M. P., Dewey, J. F., and Hancock, P. L., eds., Continental extensional tectonics: Geological Society of London Special Publication 28, p. 203-221.

Wernicke, B. P., Axen, G. J., and Snow, J. K., 1988a, Basin and Range extensional tectonics at the latitude of Las Vegas, Nevada: Geological Society of America Bulletin, v. 100, p. 1738-1757.

Wernicke, B. P., Walker, J. D., and Hodges, K. V., 1988b, Field guide to the northern part of the Tucki Mountain fault system, Death Valley region, California, in Weide, D. L., and Faber, M. L., eds., This extended land; Geological journeys in the southern Basin and Range: Las Vegas, University of Nevada Department of Geoscience Special Publication 2, p. 58-63.

Willden, R., 1964, Geology of the Christmas Quadrangle, Gila and Pinal Counties, Arizona: U.S. Geological Survey Bulletin 1161-E, p. E1-E61.

Wilt, J. C., and Scarborough, R. B, 1981, Cenozoic sediments, volcanics, and related uranium in the Basin and Range province, Arizona, in Goodell, P. C., and Waters, A. C., eds., Uranium in volcanic and volcaniclastic rocks: American Association of Petroleum Geologists Studies in Geology 13, p. 123-144.

Woodburne, M. O., Miller, S. T., and Tedford, R. H., 1982, Stratigraphy and geochronology of Miocene strata in the central Mojave Desert, California, in Cooper, J. D., ed., Geologic excursions in the California desert: Geological Society of America Cordilleran Section 78th Annual Meeting Volume and Guidebook, p. 47-64.

Woodburne, M. O., Tedford, R. H., and Swisher, C. C., III, 1990, Lithostratigraphy, biostratigraphy, and geochronology of the Barstow Formation,
Mojave Desert, southern California: Geological Society of America Bulletin, v. 102 , p. $459-477$.

Wright, J. E., and Haxel, G., 1982, A garnet two-mica granite, Coyote Mountains, southern Arizona; Geologic setting, uranium-lead isotopic systematics of zircon, and nature of the granite source region: Geological Society of America Bulletin, v. 93, p. 1176-1188.

Wrucke, C. T., 1989, The Middle Proterozoic Apache Group, Troy Quartzite, and associated diabase of Arizona, in Jenney, J. P., and Reynolds, S. J., eds., Geologic evolution of Arizona: Arizona Geological Society Digest 17 p. 239-258.

Wust, S. L., 1986a, Extensional deformation with northwest vergence, Pioneer core complex, central Idaho: Geology, v. 14, p. 712-714.

- 1986b, Regional correlation of extension directions in Cordilleran metamorphic core complexes: Geology, v. 14, p. 828-830.

Yarnold, J. C., and Lombard, J. P., 1989, A facies model for large rock-avalanche deposits formed in dry climates, in Colburn, I. P., Abbott, P. L., and Minch, J., eds., Conglomerates in basin analysis: Pacific Section, Society of Economic Paleontologists and Mineralogists Book 62, p. 9-31.

Yeend, W., 1976, Reconnaissance geologic map of the Picacho Mountains, Arizona: U.S. Geological Survey Miscellaneous Field Studies Map MF-778, scale $1: 62,500$

Yin, An, 1989, Origin of regional, rooted low-angle normal faults; A mechanical model and its tectonic implications: Tectonics, v. 8, p. 469-482.

Zoback, M. L., 1983, Structure and tectonism along the Wasatch fault zone, Utah, in Miller, D. M., Todd, V. R., and Howard, K. A., eds., Tectonic and stratigraphic studies in the eastern Great Basin: Geological Society of America Memoir 157, p. 3-27.

Zoback, M. L., Anderson, R. E., and Thompson, G. A., 1981, Cainozoic evolution of the state of stress and style of tectonism of the Basin and Range province of the western United States: Philosophical Transactions of the Royal Society of London, v. A300, p. 407-434.

MANUSCRIPT ACCEPTED By THE SOCIETY DeCEMBER 12, 1990 


\section{Tectonic setting of faulted Tertiary strata associated with the Catalina core complex in southern Arizona}

\section{Contents}

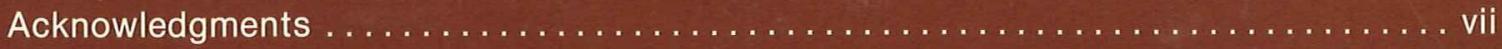

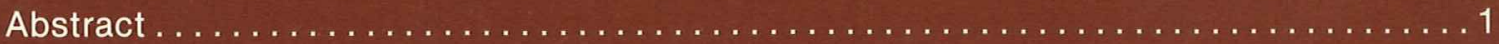

Introduction . . . . . . . . . . . . . . . . . . . . . . . . . . . . . .

Pre-Laramide Rock Assemblages . . . . . . . . . . . . . . . . . . . . 10

Laramide Geologic Features . . . . . . . . . . . . . . . . . . . . . 15

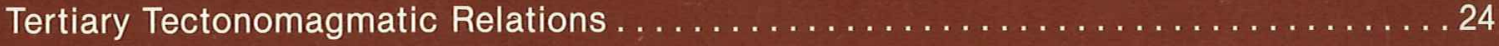

Core Complex Geometry . . . . . . . . . . . . . . . . . . . . . . 36

Alternate Structural Models . . . . . . . . . . . . . . . . . . . . . 44

Tertiary Sedimentary Assemblages . . . . . . . . . . . . . . . . . . . 49

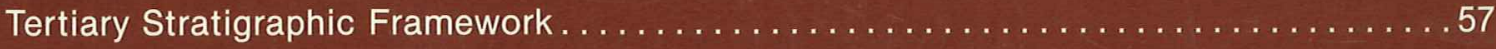

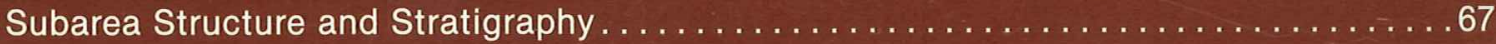

Discussion and Conclusions . . . . . . . . . . . . . . . . . . . . 90

References Cited . . . . . . . . . . . . . . . . . . . . . . . . . . . . 92 